Elizabeth Romani

\title{
DESIGN DO LIVRO-OBJETO INFANTIL
}<smiles>C1CCCCC1</smiles>

Dissertação apresentada

a Faculdade de Arquitetura e Urbanismo

da Universidade de São Paulo para obtenção

do título de Mestre em Arquitetura e Urbanismo

Área de concentração

Design e Arquitetura

Orientadora

Clice de Toledo Sanjar Mazzilli

São Paulo, 2011 
Autorizo a reprodução e divulgação total ou parcial deste trabalho, por qualquer meio convencional ou eletrônico, para fins de estudo e pesquisa, desde que citada a fonte.

elizabethromani@yahoo.com.br

Romani, Elizabeth

R758d Design do livro-objeto infantil / Elizabeth

Romani. -- São Paulo, 2011.

144p. : il.

Dissertação (Mestrado - Área de Concentração :

Design e Arquitetura) - FAUUSP.

Orientadora: Clice de Toledo Sanjar Mazzilli

1. Design gráfico 2. Projeto gráfico 3. Produção editorial

4. Livro infantil I. Título 
À profa. Clice Mazzilli pelas conversas, pelo incentivo e pela dedicada orientação.

Ao prof. Vicente Gil e à Nasha Gil pelos valiosos comentários e por acompanhar de perto os experimentos gráficos.

Ao prof. Edmir Perrotti pelos comentários precisos no exame de qualificação.

À minha família pelo constante incentivo e pela compreensão da minha bagunça.

Aos professores Marisa Deaecto, Plínio Martins e Silvio Dworecki pelas conversas.

Aos amigos, Anna Dionisi, Gabriel Pedrosa, Rodrigo Shimizu e Tomás Martins pela cuidadosa leitura.

Aos amigos que contribuíram nesta pesquisa, com bibliografia, com livros infantis e com comentários.

Ao Alessio Dionisi pela fundamental ajuda. 
This work aims to analyse both the design of book-object for children and its respective ludic instrument. This type of book has being recently published, and there is an increasing interest by the editorial sector, mainly after the 50's. The book-object is understood as a product of artistic expression and susceptible of to be reproduced. The narrative results from the interaction between the book and who is handling it. The relationship of graphic design with the ludic structure has the objective to understand the production process of the book-object. Books written by the famous authors Pacovská and Munari were chosen for the development of the case studies. These authors are quite well-known by their experimental books. This monograph contains four chapters, describing themes which are similar structured to the books written by Perrot and Linden. There is also included in this work a chapter about graphic experiments which search new possibilities for designing books. 
Esta pesquisa analisa o design do livro-objeto infantil e seus instrumentos lúdicos, categoria relacionada às produções recentes, e associada aos crescentes investimentos do setor editorial, principalmente, infantil, a partir de 1950. O livro-objeto é, aqui, compreendido como um produto de expressão artística passível de reprodução cuja narrativa é explorada por meio da manipulação. A relação do projeto gráfico com a estrutura lúdica tem como objetivo entender o processo de produção do livro-objeto. Os estudos de caso investigam essa relação nas obras de Pacovská e Munari, autores consagrados pelo uso da linguagem experimental. O estudo do livro-objeto ainda carece de bibliografia específica, por isso a construção teórica parte da junção de autores de áreas de conhecimento distintas. Esta dissertação está estruturada em quatro capítulos, abordando os temas de forma semelhante às encontradas em Perrot e Linden. O trabalho prático investiga possibilidades de projeto, ligando a teoria à produção. 

O LIVRO-OBJETO INFANTIL

O SIGNIFICADO DE LIVRO-OBJETO

O LEITOR DO LIVRO-OBJETO INFANTIL

O LÚDICO NO LIVRO-OBJETO INFANTIL

DO DESIGN À PRODUÇÃO DO LIVRO-OBJETO 27

FORMATO

TIPOGRAFIA

ORGANIZAÇÃO DA PÁGINA

LINGUAGEM VISUAL DAS ILUSTRAÇÕES

PRODUÇÃO GRÁFICA

LIVROS-OBJETO DE PACOVSKÁ E DE MUNARI 67

KVĚTA PACOVSKÁ

BRUNO MUNARI

INVESTIGAÇÃO GRÁFICA DO LIVRO-OBJETO 117

EXPERIMENTO 1 

Este trabalho apresenta uma análise da estrutura lúdica e do design de livros-objeto infantis, entendidos como produto artístico e reproduzível, cuja narrativa é explorada por meio da manipulação. Faz parte desta pesquisa a apropriação do lúdico no projeto gráfico.

A produção do livro infantil, no Brasil, é considerada recente, sendo que sua expansão se concentrou nas últimas cinco décadas do século XX. O livro-objeto infantil se relaciona aos crescentes investimentos no setor editorial e às recentes tecnologias evidenciadas nas publicações a partir da década de 1990. Novas formas de manipulação são cada vez mais exploradas, testando os limites da percepção.

Nesta pesquisa, procura-se estabelecer a relação do design com os instrumentos lúdicos, com o objetivo de entender o processo de produção do livro-objeto infantil. Entende-se como objetivo secundário, o estudo das teorias do design relacionadas ao livro. Ao mesmo tempo, busca-se documentar e associar os recursos de design a livros publicados, estabelecendo uma ponte entre os recursos lúdicos e os experimentos gráficos.

Os estudos de caso têm como objetivo secundário mostrar como se aplica a teoria do design nos livros-objeto de dois consagrados autores, Pacovská e Munari, descrevendo com detalhes como cada conceito de design é aplicado. Os experimentos gráficos investigam possibilidades de projeto, testando diferentes manifestações do lúdico no suporte livro.

O trabalho teórico consiste na junção de vários autores que tratam de assuntos correlatos ao da pesquisa, uma vez que não se dispõe de uma produção específica sobre o tema, design do livro infantil ou do livro-objeto. Os seguintes autores são incorporados para entender: a natureza do livro-objeto, Linden, Paiva e Silveira; o lúdico, Caillois, Huizinga e Perrot; a linguagem visual, Dondis, Hulburt, Lupton, Nodelman e Munari; design do livro, Araújo, Haslam, Heller, Hendel e Tschichold.

A análise é estruturada de forma semelhante à encontrada nos livros de Linden e Perrot, relacionando os temas abordados com exemplos de livros infantis. Fotos e um pequeno texto sobre o livro mostram uma possível interpretação sobre a teoria trabalhada. Os livros utilizados nos estudos de caso seguem alguns critérios de seleção como: disponibilidade no mercado editorial, inovações visuais e instrumentos lúdicos. 
O trabalho teórico sobre o lúdico no livro e os elementos de design são aplicados numa análise posterior sobre algumas obras de Munari e Pacovská. O critério de seleção para os estudos de caso vincula-se ao fato destes possuírem um caráter experimental em suas obras. Autores reconhecidos, internacionalmente, pela produção lúdica, seus livros exploram a manipulação associada ao projeto gráfico cuidadoso.

A dissertação está estruturada em quatro capítulos e considerações finais. 0 primeiro capítulo busca entender o objeto estudado e as características do livro-objeto infantil, a partir de definições de campos correlatos. Sua natureza híbrida mistura literatura e artes visuais, o estudo específico sobre este tema, no entanto, é ainda incipiente.

A narrativa do livro-objeto é explorada pelo leitor por meio da manipulação, permitindo uma leitura singular. Este tipo especial de livro contém mecanismos que viabilizam o jogo, ao mesmo tempo, que valorizam o caráter experimental das linguagens.

Este trabalho propõe não restringir sua pesquisa a faixa etária, de forma que a classificação "infantil" seja mais um método para estabelecer um critério de seleção dos exemplos e estudos de caso. Grande parte do experimentalismo lúdico encontra-se nos livros infantis, que exploram novas formas de linguagem e de manipulação. Os livros apresentados nesta pesquisa, no entanto, encantam todos os tipos de leitores, da criança ao adulto.

O jogo no livro provoca a manipulação diferenciada, explora a criatividade e a percepção do leitor. Os instrumentos lúdicos são as ferramentas de projeto que diferenciam o livro tradicional do livro-objeto. Os jogos são classificados em sinestésico, de adivinhação, de imagens e com recortes, podem aparecer sozinhos ou em conjunto no livro, pois não existe uma regra para sua utilização, cada projeto estabelece sua proposta lúdica.

No segundo capítulo, busca-se estabelecer os critérios de design e suas especificidades no projeto do livro-objeto, para tanto recorre-se à teoria sobre o design do livro tradicional. Buscam-se em meio a esta teoria, os pontos comuns e divergentes para a construção do texto. $O$ design do livro-objeto exige um projeto diferenciado, entre suas especificidades pode-se citar: pequena ou ausência de massa de texto, formato inusitado, linguagem experimental das ilustrações e produção gráfica diferenciada.

O formato caracteriza o aspecto físico do livro-objeto. Este tem o poder de incentivar a fantasia, porque é a primeira impressão que o leitor terá do objeto. O formato associado ao tamanho tem a capacidade de expressar sensibilidade, por exemplo: livros menores expressam sutileza e delicadeza. O projeto, para determinar o melhor formato, deve levar em conta a proporção conveniente à leitura e à manipulação, bem como pensar nos formatos disponíveis do substrato utilizados em sua produção, visando ao melhor aproveitamento do material e redução do desperdício.

A tipografia do livro-objeto é peculiar a cada caso. Alguns fatores a tornam singulares como: as edições em línguas diversas, a tipografia feita pelo artista e a escassez de texto. Nesta pesquisa, o assunto é esboçado num quadro geral, trabalhando sempre que possível sobre o panorama da tipografia no livro infantil.

A organização da página está ligada ao seu formato. As informações contidas na página, texto e imagem, geralmente, são organizadas por malhas, mas nem todos os livrosobjeto organizam-se desta forma. O sistema de malha básico determina as larguras das 
margens, as proporções da mancha gráfica e a localização dos elementos que se repetem no layout. No livro-objeto, quando obedecem a uma malha, esta se diferencia do texto e da imagem.

A linguagem da ilustração define os aspectos formais da imagem, bem como estabelece o ritmo narrativo. Existem inúmeras técnicas aplicadas na ilustração de livros, aquarela, acrílico, nanquim, colagem, digital, mas, independente da técnica aplicada, todas as imagens obedecem aos princípios de linguagem gráfica, cor, forma, ritmo, textura, escala, figura-fundo e movimento. Cabe ao ilustrador explorar cada técnica para obter um resultado diferenciado e, ao mesmo tempo, fornecer uma imagem clara ao leitor.

É na produção gráfica que se encontra grande parte dos instrumentos que propiciam o lúdico. Apesar de ser a parte final no processo de produção, essa deve ser concebida junto ao primeiro esboço do projeto. A produção gráfica é composta da pré-impressão, da impressão e do acabamento. Conhecer os processos de produção é uma forma de se instrumentalizar frente a problemas e soluções nos livros impressos. No livro-objeto, as escolhas de produção potencializam o lúdico, além de agregar valores estéticos.

No terceiro capítulo, retomam-se os elementos de design e os instrumentos lúdicos para um estudo mais aprofundado em seis estudos de casos. Os livros de Munari e Pacovská permitem confrontar a teoria com a produção de seus livros-objeto infantis. Autores importantes no contexto editorial infantil, premiados internacionalmente, caracterizam-se pela produção experimental, em que a manipulação está muito presente.

Pacovská é de origem tcheca e atua em variadas artes, pintura, design, escultura, poesia e performance. Nas suas obras, mistura técnicas que resultam na criação de uma linguagem visual singular e facilmente reconhecida, como o uso predominante de figuras geométricas, cores vivas e contrastantes, e ilustrações que sobrepõem colagem e pintura.

Muitos dos temas trabalhados pela autora são extraídos dos contos de fadas. As suas recentes publicações, a partir da década de 1990, caracterizam-se pela sofisticação gráfica e por apresentar maior experimentalismo lúdico. A escolha dos livros para a análise, Alphabet, Jamais deux sans trois e MidNightPlay, baseia-se nos seguintes critérios: ser um livro-objeto, apresentar inovações visuais e ser um objeto instigante para o leitor. Consequentemente, possuem uma cuidadosa produção gráfica.

O italiano Munari teve intensa atuação nos campos da arte, design e fotografia, na metade do século XX. O autor é referência por sua produção teórica e pelo caráter experimental de suas obras, defende a aplicação da criatividade nos projetos gráficos e industriais. As obras de Munari são marcadas pela invenção, propondo novos olhares sob a perspectiva do livro e estimulando a participação ativa do leitor na narrativa.

Munari defende o uso da linguagem mais universal possível, considerando com questão prioritária a clareza e a simplicidade da informação. Dessa forma, utiliza uma linguagem visual limpa, sem muitos detalhes numa mesma imagem. A escolha dos livros para análise, Na noite escura, Più e meno e The circus in the mist, baseia-se nos mesmos critérios adotados na escolha dos livros de Pacovská.

No quarto capítulo, trabalhou-se as investigações gráficas obtidas por meio de experimentos baseados na teoria apresentada nos capítulos anteriores. A investigação proposta 
tem como objetivo experimentar processos de produção e formas de narrativa utilizando como base o livro-objeto, criou-se alguns protótipos sem estabelecer uma faixa etária para o leitor.

Os trabalhos de Munari e Rand inspiraram parte das investigações desenvolvidas. A partir de temas quotidianos como: cidade, mar, números, frutas, entre outros, os experimentos caminham em diferentes expressões do lúdico. O produto final destes experimentos são objetos artesanais, demonstrando possibilidades para o design do livro-objeto infantil.

Nas considerações finais, uma breve observação estabelece algumas das relações encontradas entre a teoria estudada e os trabalhos práticos. 
O mercado editorial voltado aos pequenos leitores no Brasil é considerado recente, sendo que sua expansão nas últimas décadas, em termos qualitativos e quantitativos, devese aos investimentos associados às recentes tecnologias.

O livro-objeto, assim como o livro infantil tradicional, tem presenciado inovações em sua produção, associadas ao computador, principalmente a partir da década de 1990. As facilidades na reprodução permitiram que os designers explorassem nos livros novas formas de manipulação.

Nos livros infantis é encontrada a maior variedade de experiências gráficas, pois estes estão livres da clássica diagramação para livros, com predomínio da narrativa visual. Segundo Heller (1994), o maior ganho no mercado editorial infantil está na diversidade das publicações, que abrangem desde sofisticados acabamentos a produções experimentais. Os limites da percepção do pequeno leitor passam a ser incorporados nos projetos gráficos.

A experimentação está presente na tipografia, na ilustração e na produção do objeto. Projetos inusitados são cada vez mais recorrentes, porque os designers passam a agregar no objeto livro a potencialidade do uso do papel, viabilizando o pop-up, o lift-up, o flap, entre outros instrumentos lúdicos.

Os pequenos leitores adoram interagir com o objeto livro, manipular ou passar a mão na textura das folhas. As inovações projetadas nos livros infantis são as responsáveis por este despertar. Dondis (1997) defende que a informação visual é apreendida de muitas maneiras, entre as quais a percepção e a sinestesia.

\footnotetext{
A primeira experiência por que passa uma criança em seu processo de aprendizagem ocorre através da consciência tátil. Além desse conhecimento 'manual', o reconhecimento inclui o olfato, a audição e o paladar, num intenso e fecundo contato com o meio ambiente. Esses sentidos são rapidamente intensificados e superados pelo plano icônico - capacidade de ver, reconhecer e compreender, em termos visuais, as forças ambientais e emocionais (DONDIS, 1997, p.6).
} 
Nesta pesquisa, procura-se estabelecer a relação do design com os instrumentos lúdicos, com o objetivo de entender o processo de produção do livro-objeto infantil. Desta forma não abordaremos o livro como um produto de mercado.

\section{O SIGNIFICADO DE LIVRO-OBJETO}

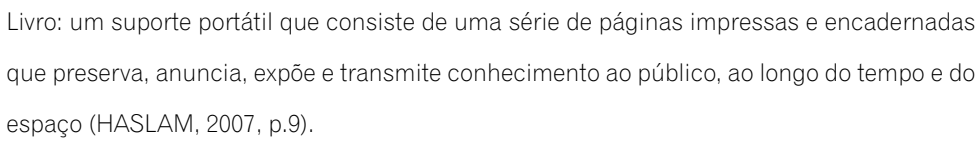

O livro é um objeto que faz parte do quotidiano da sociedade. Qualquer pessoa entende o significado da palavra livro, mas suas características não podem ser definidas sem uma correta especificação.

A bibliografia específica sobre livro-objeto é ainda incipiente, de natureza híbrida, transitando entre as artes e a literatura.

Os livros podem ser classificados de diferentes formas, seguindo categorias comandadas pelo conteúdo narrativo. Algumas, aqui apresentadas, servirão de guia para entender o significado do livro-objeto. É comum encontrar designações em inglês ou em francês, por isso algumas expressões utilizadas nesta pesquisa não serão traduzidas, evitando confusões de semântica, uma vez que muitas delas ainda não possuem uma palavra equivalente em português.

Consultaram-se diferentes fontes na tentativa de buscar uma definição mais próxima do objeto pesquisado. Não é objetivo da pesquisa olhar os aspectos literários e os educativos nas obras levantadas, mas, sim, investigar questões específicas do design do livroobjeto. Paiva (2010, p.84) classifica os livros em:

LIVRO DE LEITURA SEQUENCIAL ensaios, memórias, romance, novela, poesia, teatro, história em quadrinhos.

LIVRO OBRAS DE REFERÊNCIA anuário, dicionário, manual, enciclopédia, catálogo, guia, relatório, livro didático.

LIVRO DIGITAL OU E-BOOK um e-book, abreviação de eletronic book, é um livro em formato digital, que pode ser lido em equipamentos eletrônicos tais como computadores, PDAs ou até mesmo celulares que suportem esse recurso. [...]

LIVRO RARO entenda-se antigo, característico de um marco histórico, precioso, representativo, esgotado, edição limitada, reduzido número de exemplares no mundo, referente, ornamental, de aspectos diferenciados (papel, gravura, encadernação) [...]

LIVRO DE ARTE é toda obra que trata do assunto arte - conjunto dos princípios e técnicas característicos de um ofício ou profissão, campos do conhecimento humano relacionados à criação, movimentos artísticos, artes plásticas e manifestações estéticas, técnicas e habilidades humanas que registraram as idéias e os ideais de culturas e étnicas, experiências e práticas. [...] 
LIVRO DE ARTISTA dos anos 1960 em diante a categoria livro de artista inclui o livro-objeto e o livre-jeu. Trata de um produto artesanal da arte contemporânea. É construído a partir de um modelo de suporte conhecido, o livro protótipo, ao qual reverencia, ora faz contraposição, enaltece, ora experimenta possibilidades de crise.

FLIP BOOK é o termo patenteado pelo inglês John Barnes, no século XIX, para designar um livro animado, de potencial narrativo sui generis. Também chamado de cinema de polegar, cinema de bolso e cinema de mão. [...]

LIVRO POP-UP livro que salta para fora, livro jump, que cria janelas de leituras inesperadas, eloquentes. A origem dessa tecnologia tem raízes na arte do origami [...]

LIVRO FORE-EDGE revoluciona a perspectiva de capa e invólucros visuais. Fore-edge: significa aresta e fore, frente. A pintura fore-edge, tradicional em livros de artistas ou antigos livros recuperados produzidos na Inglaterra, funciona da seguinte maneira: quando o bloco de páginas é aberto em leque, uma imagem é aplicada à superfície destacada, dando às arestas uma impressão dourada se fechada e marmorizada - marcada com cores que formam imagens - se abertas [...]

Linden (2007) classifica os livros infantis em seis categorias, de acordo com sua apreensão da relação texto, imagem e objeto:

PRIMEIRAS LEITURAS denominação editorial que se dirige especificamente aos leitores principiantes. A paginação assemelha-se às histórias ilustradas, imagens enquadradas junto ao texto, aproximando por vezes ao álbum.

ALBUM livros nos quais a imagem encontra-se espacialmente preponderante em relação ao texto, podendo o restante estar ausente. A narração é realizada de maneira articulada: texto e imagem.

BANDAS DESENHADAS imagens soltas e desarticuladas, imagens solitárias. Elas aparecem dispostas de forma compartimentada.

LIVROS ANIMADOS tipos de livros que tratam do espaço da dupla, sistemas de esconderijos, de dobras para trás, de corrediças que permitem a mobilidade dos elementos ou mesmo uma apresentação em três dimensões (pop-up).

LIVROS-OBJETO objetos híbridos, situados entre o livro e o brinquedo, correspondem aos objetos que se assemelham aos livros ou livros que acolhem um objeto em três dimensões (de pelúcia, boneco de plástico).

LIVROS DE ATIVIDADES livros que se assemelham como suporte de atividades, autocolantes, para colorir, construções, recortes, entre outras propostas recreativas, podendo acolher materiais necessários para a atividade manual.

O álbum, em francês, e o picture book, em inglês, possuem o mesmo significado, um livro em que a narrativa se faz pela junção da ilustração com o texto durante a leitura. O leitor é a ponte das imagens e das palavras, cada elemento não funciona isoladamente. Segundo Shulevitz (1997), o picture book necessita do equilíbrio entre texto e imagem, para o entendimento total da obra. 

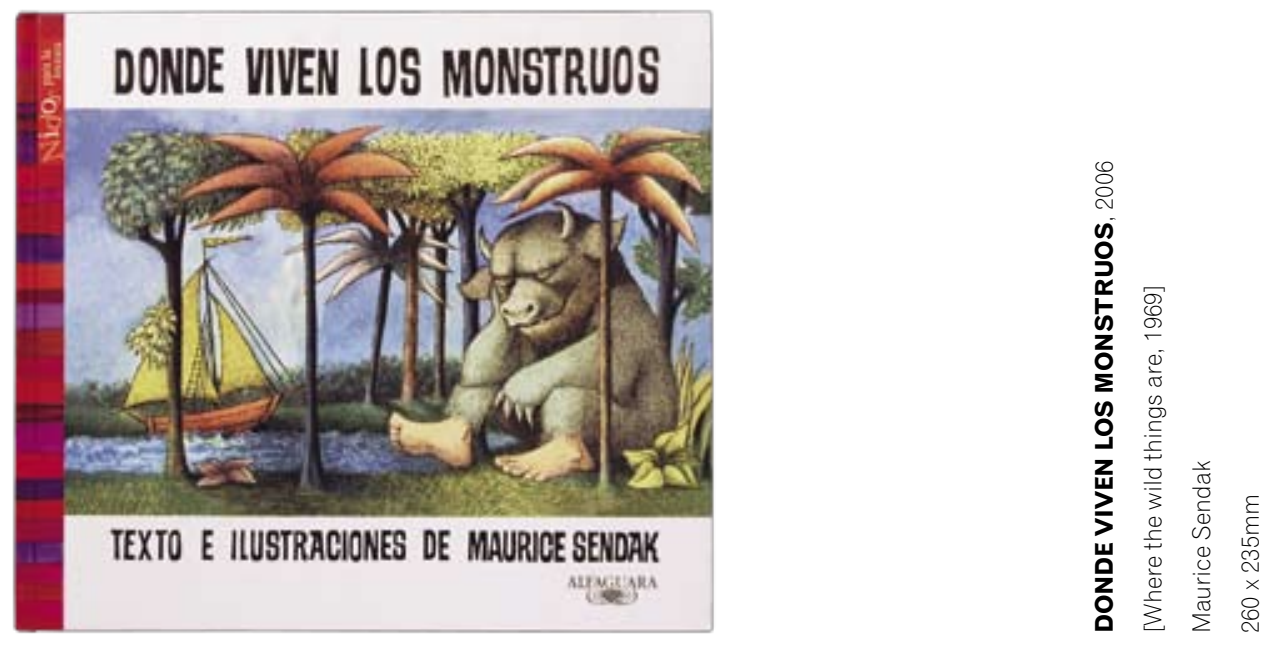

Maurice Sendak, considerado um dos precursores do picture book, mescla palavras e imagens para a construção da narrativa. Em Donde viven los monstruos, ele muda o conceito de livro ilustrado quando propõe descrever a raiva infantil por meio de um texto reduzido apoiado nas ilustrações.

Heller (1994) apresenta uma definição mais precisa e divergente das autoras citadas acima, Linden e Paiva, utilizando as expressões book-as-object e paper toy. Ambos definem o livro-objeto como a interseção das categorias livro de artista e picture book.

Os autores de tradição francesa colocam o livro-objeto dentro da categoria livrobrinquedo, que designa os livros brincantes, experimentais, inventivos e performáticos:

\footnotetext{
Todo objeto de transfiguração da leitura que materialize o sensório, o plástico, a originalidade na concepção, intervenções poéticas, jogos gráficos e visuais. Objetos que estabeleçam uma nova emoção ao leitor - informando, estimulando, intrigando, comovendo e entretendo
}

(PAIVA, 2001, p.91)

O livro-brinquedo pode ser entendido como uma ligação entre dois universos: cultural e diversão. "O brinquedo, nas suas formas mais distanciadas do livro, surgiu em nossa cultura para oferecer uma leitura dela às crianças, permitindo-Ihes apreender alguns dos significados que a constituem. A criança é, então, confrontada com um objeto de brincadeira. Ela manipula, por intermédio da multiplicidade de objetos, o consumo, a inovação tecnológica, os novos vetores da cultura, tanto nos seus conteúdos quanto na relação que estabelece com a criança". (BROÜGÈRE, 2004, p.269)

Segundo Paiva (2010), o livro de artista engloba as categorias: livro-jogo, flip book, livro-objeto, pop-up e fore edge. Livros que valorizam a manipulação experimental das linguagens visuais e sinestésicas, expandindo o acesso à arte pela criação do interesse de leitura pelo lúdico por meio do prazer, divertimento ou fantástico. 


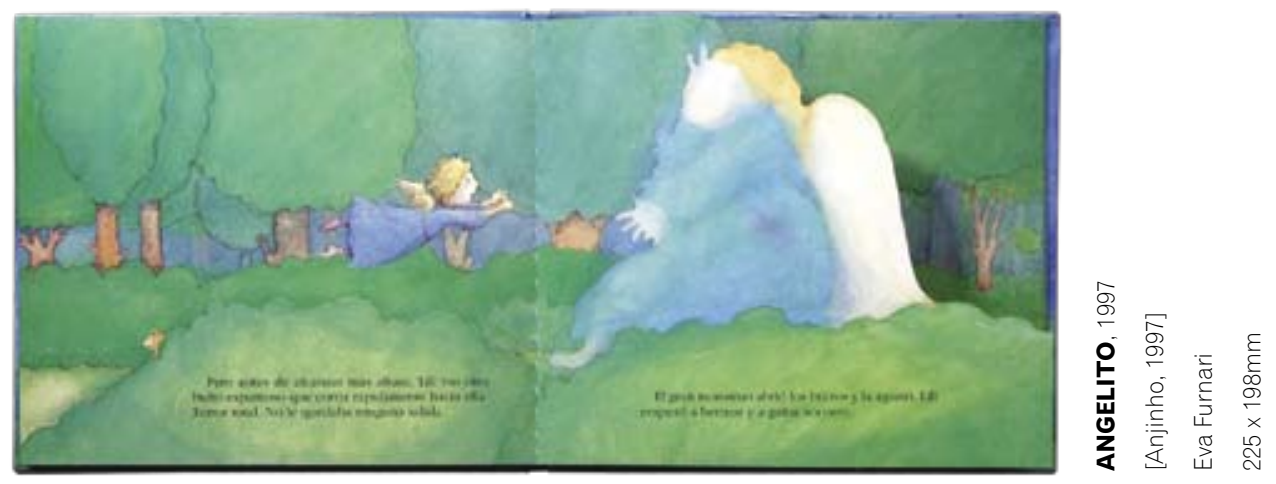

O livro de artista é geralmente caracterizado pela reprodução limitada, definida pelo grau de experimentalismo e individualismo (FABRIS; COSTA, 1985). Nesta pesquisa, o que está em questão é o livro-objeto que possa ser reproduzido em escala industrial.

Na década de 1950, no Brasil, momento em que a concepção de livro de artista se firma, os artistas passaram a privilegiar a imagem gráfico-espacial como forma, enfatizando a presença de elementos visuais, principalmente, nos poemas-objeto. O espaço gráfico passa a ser o lugar de discussão entre forma e conteúdo, trabalha-se o limite da forma do livro, baseadas no manuseio expressivo, gerando uma experiência multissensorial (FABRIS; COSTA, 1985).

A produção de livro-objeto firma-se após o manifesto neoconcreto, o que o transforma numa produção artística, com a narrativa livre e as páginas soltas convidativas ao manuseio. Obras consideradas transitórias porque a percepção narrativa muda a cada leitura.

O livro-objeto exige a participação do leitor, o qual experimenta conteúdos, formas, efeitos, funções, nova disposição espaço-temporal, sonoridades, deslocamentos, limites, levezas e estranhamentos. A poética visual é o ponto forte do livro (PAIVA, 2010). Para os neoconcretos, "[...] a origem da participação do espectador na obra não poderia ter sido mais natural e simples: nasceu do livro, que é, por definição, um objeto manuseável" (GULLAR, 2007, p.50).

A narrativa sequencial presente nos livros-objeto pode ser encontrada nas dobraduras e nos encartes, expressando-se tanto pelas possibilidades de articulação, como pela surpresa de novas informações. A inovação aparece também na quebra da linearidade do enredo (SILVEIRA, 2001).

Este trabalho não propõe instituir uma classificação para o livro-objeto, mas busca entender suas características para o estudo proposto. Para esta pesquisa, o livro-objeto é visto como um produto reproduzível de expressão artística, em que a narrativa é explorada pelo leitor por meio da manipulação, permitindo uma forma de leitura singular. 

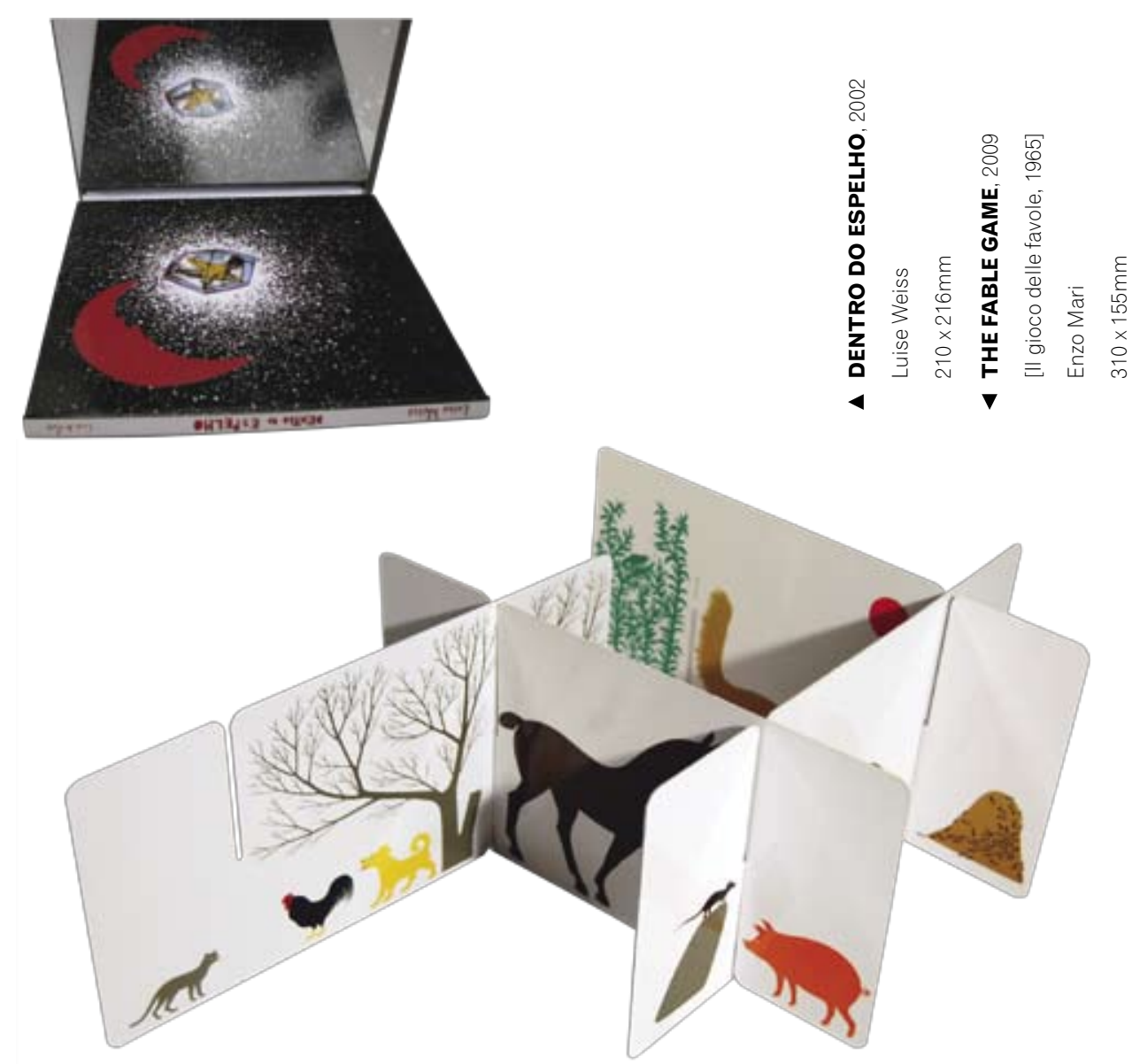

Os livros-objeto a seguir exemplificam diferentes formas de tratar o mecanismo lúdico. Em Angelito, Furnari trabalha com a intercalação de folhas recortadas, na qual a silhueta do recorte esconde outra versão à ilustração proposta. A autora brinca com a possibilidade de diferentes desenhos utilizarem o mesmo contorno.

Dentro do espelho é um livro-objeto desenvolvido a partir de experiências plásticas, explorando a linguagem gráfica do recorte e da pintura. Consiste numa sequência narrativa com imagens e textos espelhados para que a leitura se dê através do espelho. O leitor manipula as páginas e o espelho de forma a obter uma leitura singular da obra, cada ângulo de inclinação propicia um novo olhar.

Enzo Mari constrói o livro-objeto, The fable game, por meio de cartelas soltas, montadas pelo leitor. As seis cartas são desenhadas com personagens e elementos recorrentes dos contos de fadas. As narrativas, com as diversas combinações das cartelas, são inventadas à medida em que a estrutura é construída espacialmente, propiciando um jogo contínuo de fábulas.

No livro-objeto Galopel, a energia do virar das páginas cria o efeito visual de movimento dos animais, o que o autor, Rufus Seder, chama de scanimation. O mecanismo de interação é inspirado nos estudos de Eadweard Muybridge sobre a fotografia em movimento. 


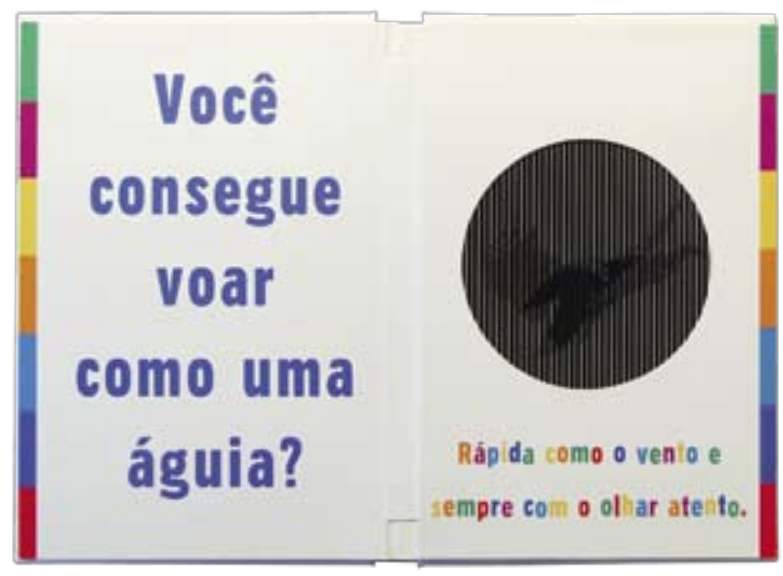

\section{O LEITOR DO LIVRO-OBJETO INFANTIL}

O livro-objeto é explorado como suporte à imaginação graças a seu poder de encantamento, possibilitando-Ihe ampliar as experiências e as perspectivas do imaginário. Para o público infantil, o livro-objeto torna-se envolvente, facilitando o processo de leitura.

A expressão "infantil" sugere um produto destinado à criança. O livro infantil é voltado, preferencialmente, aos pequenos leitores, porém ele não se limita a atingir uma determinada faixa etária, restringindo a leitura. Um livro pode ser relido em diversas fases da vida, desde que não seja tratado de forma infantilizada.

O hábito da leitura deve ser promovido ainda na infância. O livro para ser uma fonte de estímulos aos pequenos leitores deve ser diferente da informação institucionalizada que recebe na escola. A imagem da leitura, para este fim, deve ser divertida, atrativa e descompromissada, o livro pode ser visto como fonte de prazer e estímulos à curiosidade e ao interesse pelo mundo (PERROTTI, 1990).

Segundo Zilberman (2005), um bom livro é aquele que agrada, não importando a faixa etária, sexo e a nacionalidade de seu público alvo. Ao livro que agrada se costuma voltar, lendo-o de novo, no todo ou em parte, retornando, de preferência, àqueles trechos que provocam prazer particular.

Munari (2007) defende que a aplicação do lúdico na idade infantil, como instrumento indutor de conhecimento e memorização de dados, estimula a criatividade e a fantasia. O jogo permite que a criança intervenha, participe e coloque em ação a sua imaginação para a solução de futuros problemas, através de associação com fatos memorizados durante a infância.

Quando uma criança lê um livro, ela aprende não apenas com o significado das palavras, mas incorpora os valores estéticos. As páginas de um livro infantil exigem um cuidadoso desenho. Segundo Heller e Guarnaccia (1994), a virtude não deve estar presente apenas nas ilustrações, mas na forma na qual elas estão dispostas e como o leitor reage a este estímulo. 


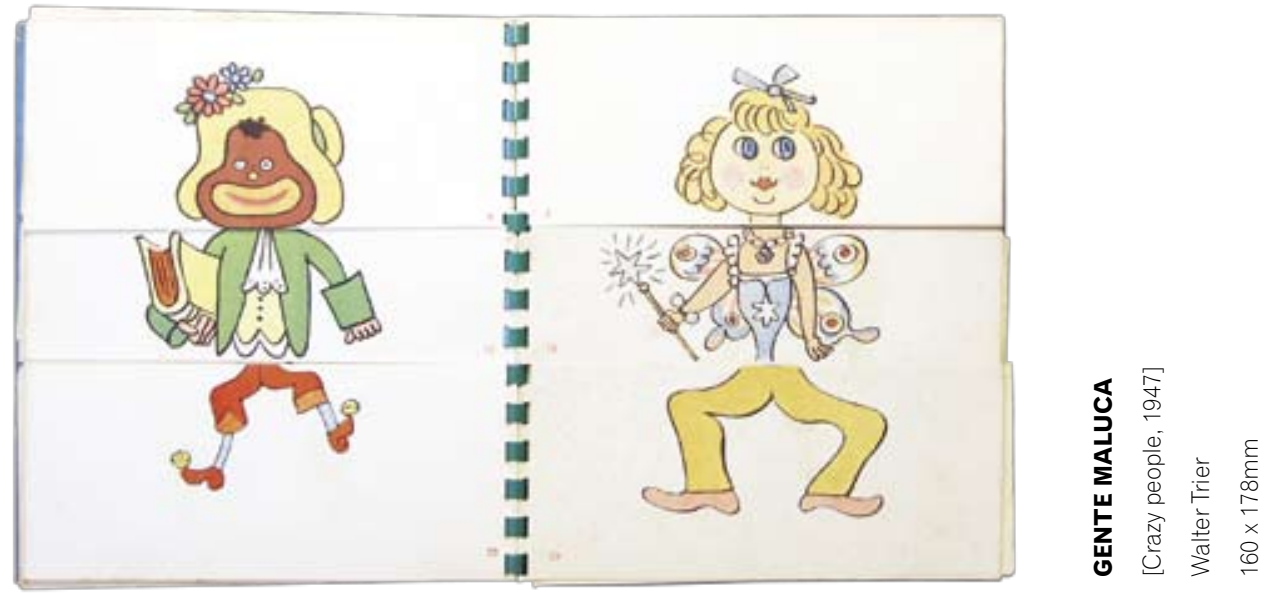

O leitor exerce um importante papel no livro-objeto, ele participa da obra. A ação de virar as páginas, a escolha no movimento das folhas, permite ao leitor a mudança no ângulo de visão e leitura exclusiva da obra (LAGO, 2008).

O presente trabalho não adota uma faixa etária dos leitores para os livros-objeto analisados. O infantil, neste caso, é um critério de seleção para os estudos de caso. Os livros-objeto ilustrados nesta pesquisa são classificados como infantils contudo encantam desde o pequeno leitor ao adulto.

Walter Trier, em Gente Maluca, propõe um jogo visual aberto a todas as idades, que descreve como sendo destinado a "crianças de 5 a 75 anos".

\section{O LÚDICO NO LIVRO-OBJETO INFANTIL}

O jogo, presente no livro, promove a manipulação diferenciada e explora a criatividade e a percepção do leitor. Os instrumentos lúdicos são as ferramentas de projeto que diferenciam o livro tradicional do livro-objeto.

O lúdico consiste em um sistema de regras voltado a uma atividade física ou mental que permite o desenvolvimento de habilidades infantis, cognitivas e motoras, além de novos experimentos. Huizinga (2007, p.33) define o jogo como:

[...] uma atividade ou ocupação voluntária, exercida dentro de certos e determinados limites de tempo e de espaço, segundo regras livremente consentidas, mas absolutamente obrigatórias, dotadas de um fim em si mesmo, acompanhado de um sentimento de tensão, de alegria e de uma consciência de ser diferente da vida quotidiana.

A partir dos estudos de Huizinga, Caillois (1994) redefiniu o jogo dentro do contexto social, incluindo em suas pesquisas os jogos de azar, a mímica e a interpretação. Segundo 
Caillois (1994, p.37-38), o jogo é definido como sendo uma atividade: livre; limitada; incerta; improdutiva; regulamentada e fictícia,

\footnotetext{
$1^{\circ}$ Libre: a la cual el jugador no podría estar obligado sin que el juego perdiera al punto su naturaleza de diversión atractiva y alegre;

$2^{\circ}$ Separada: circunscrita en límites de espacio y de tiempo precisos y determinados por participado;

$3^{\circ}$ Incierta: cuyo desarrollo no podría estar predeterminado ni el resultado dado de antemano, por dejarse obligatoriamente a la iniciativa del jugador cierta libertad en la necesidad de inventar;

$4^{\circ}$ Improductiva: por no crear ni bienes, ni riquezas, ni tampoco elemento nuevo de ninguna especie; $y$, salvo desplazamiento de propiedad en el seno del círculo de los jugadores, porque se llega a una situación idéntica a la del principio de la partida;

$5^{\circ}$ Reglamentada: sometida a convenciones que suspenden las leyes ordinarias e instauran momentáneamente una nueva legislación, que es la única que cuenta;

$6^{\circ}$ Ficticia: acompañada de una conciencia específica de realidad secundaria o de franca irrealidad en comparación con la vida corriente.
}

Um jogo isolado, sem seu contexto cultural e temporal, pode apresentar diferentes resultados. Portanto, um jogo deve ser compreendido por todos os participantes para que haja a interação e a continuidade da ação. Procurou-se, por isso, estudar o livro-objeto que apresenta o caráter mais universal, sem abordar especificidades culturais e simbólicas.

O jogo dentro de um livro pode ser considerado um suporte à imaginação. Os objetos lúdicos são utensílios para o desenvolvimento da criança e a forma como estes são concebidos gera a diferença numa relação mais afetiva da criança com o objeto. O livro por si só não é considerado um jogo, e terá sentido lúdico de acordo com o meio pelo qual o usuário faz uso dele. As informações contidas no livro são decodificadas pela criança, permitindo a esta o estabelecimento da interação (BROÜGÈRE, 2004).

O livro-jogo é compreendido nesta pesquisa como sendo um livro com propostas lúdicas, permitindo às crianças o envolvimento com o objeto, seja por meio de brincadeiras ou pela sinestesia. O ritmo da leitura, a forma do objeto e a disposição das ilustrações são exemplos de instrumentos de interação com o livro, em que o leitor é convidado a participar da narração por meio da manipulação do objeto ou pela interpretação pessoal.

O lúdico desperta interesse crescente na criança, pois suscita emoções, estimula os sentidos e mobiliza a energia da criança na manipulação do objeto, ajudando-a no seu desenvolvimento. A manipulação do livro pode acalmar e, ao mesmo tempo, prender a atenção da criança (PERROT, 1987).

Além disso, o livro-jogo pode exercer o mesmo encantamento que um brinquedo. O uso de cores, ilustrações e o trabalho com a forma do objeto permitem à criança a leitura da imagem como um pequeno explorador, ampliando a perspectiva do imaginário. A criança se insere num mundo mágico que a motiva a abrir e a fechar o livro repetidas vezes, num processo de releitura e novas descobertas (PERROT, 1987). 

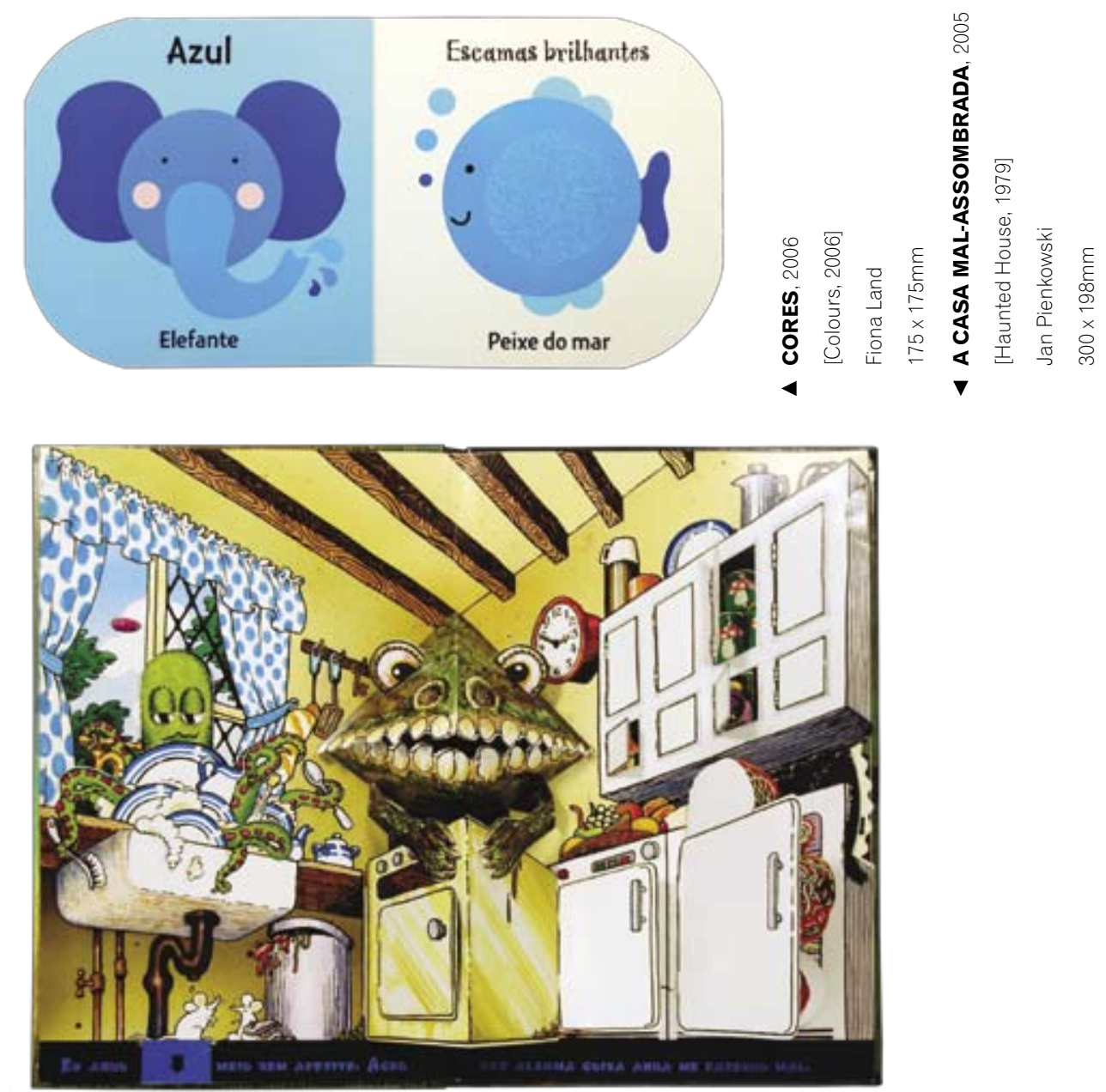

Baseado nos estudos de Perrot (1987) sobre o livro-jogo, foram extraídos alguns exemplos teóricos de instrumentos lúdicos encontrados nos livros infantis. Metodologicamente, aqui classificados em: jogo sinestésico, jogo de humor, jogo de adivinhação, jogo de imagens e jogo com recortes. No livro-objeto, o jogo está vinculado à manipulação pelo leitor, o que justifica o uso de diversos instrumentos lúdicos concomitantes.

O jogo sinestésico consiste na exploração dos sentidos da criança como a visão, audição, tato e olfato. É um tipo de jogo muito encontrado em livros destinados às crianças não alfabetizadas, geralmente, livros confeccionados com materiais mais rígidos, com poucos textos e ilustrações sem muitos detalhes.

Cores, da coleção Toque e Descubra, apresenta as cores em diferentes texturas e brilho, explorando a sensação tátil por meio dos materiais. A experiência do contato físico é recomendada para crianças pequenas que ainda não acumularam tantas referências. Este livro-objeto é projetado para o pequeno leitor, por isso é composto em cartão laminado e empastado, o que garante sua rigidez. Detalhes de projeto como cantos arredondados nas páginas, ausência de grampos, formato e peso, permitem que a criança consiga segurar e manipular o livro. 


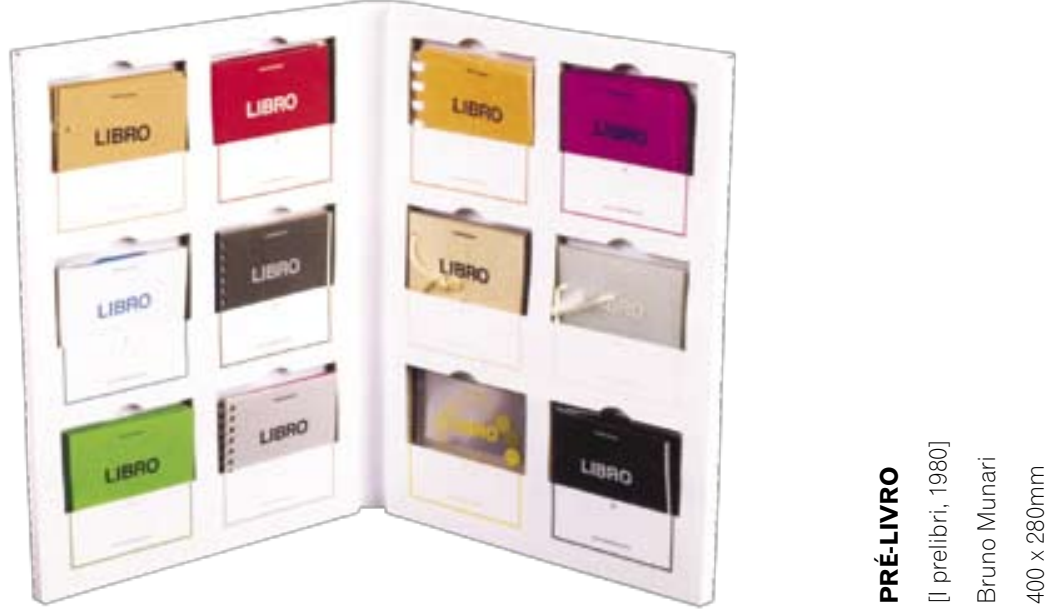

A exploração do prazer tátil consiste em um recurso lúdico aplicado em muitos livros-objeto infantis. O recurso simula uma textura condizente com o real ou pode ser aplicado para causar uma estranheza, ou seja, quando não há uma correspondência entre a imagem e a textura, incentivando a reflexão do leitor (PERROT, 1987).

Alguns livros trabalham com a produção de som a partir da manipulação das páginas. O movimento de girar a página aciona o mecanismo, aproveitando a energia do folhear para explorar o sentido da audição (PERROT, 1987).

No livro A casa mal-assombrada, o leitor é surpreendido com os efeitos sonoros, através da emissão do som de um serrote e do ranger da boca do monstro durante a abertura e o fechamento do livro. Neste sofisticado pop-up, o lúdico é explorado também nas imagens tridimensionais, o que aumenta a expectativa do leitor. Rico em detalhes e espaços volumétricos, o leitor é convidado a descobrir as surpresas por detrás de cada seta e janela.

Os Pré-livros são constituídos por doze pequenos experimentos sinestésicos, em que cada livro explora um sentido. Esses pequenos livros, quadrados de $100 \mathrm{~mm}$, foram confeccionados a partir de diversos materiais, encadernações e cores, e possuem como título: "Livro" - escrito tanto na capa como na contracapa, de forma a não haver sentido para leitura.

Com a percepção das sensações táteis, térmicas, sonoras e olfativas, pode-se projetar um conjunto de objetos semelhantes aos livros - porém todos diferentes para a informação: visual, tátil, material, sonora, térmica - todos do mesmo formato, como os volumes de uma enciclopédia que conte todo o saber ou, pelo menos, muitas e diferentes informações (MUNARI, 2002, p.223).

O humor, nos livros, ajuda a criança a relaxar e a redobrar a imaginação. O jogo de humor pode ser visto por meio das ilustrações absurdas ou numa realidade sem sentido. O humor deve ser universal nos livros, de forma a funcionar em todas as línguas (PERROT, 1987). 

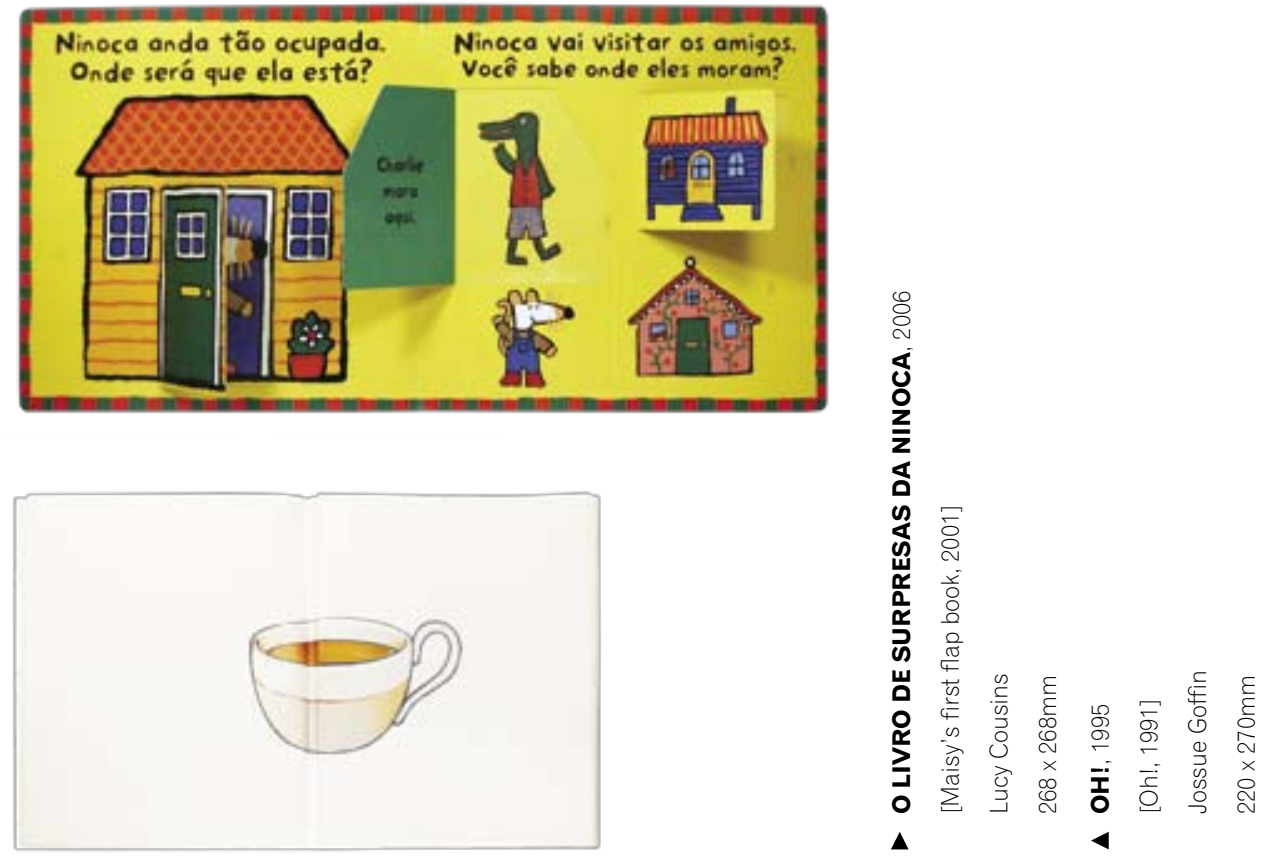

O jogo de adivinhação trabalha com a diversão, embora não menos reflexivo. Em alguns livros o uso da parte de uma palavra ou de um desenho funciona como um grande quebra-cabeça a ser montado pela criança ao longo da leitura. Em cada página uma pista, que possibilita a assimilação da construção do final pelo leitor (PERROT, 1987).

No livro-objeto o humor e a adivinhação são jogos que vêm acompanhados de outros instrumentos lúdicos. O Livro de Surpresas da Ninoca pertence à coleção Ratinha Ninoca, de semelhante princípio de interação, que por meio de diferentes aberturas dentro do próprio livro (janelinhas que se abrem e se fecham), revelam a resposta da charada proposta. Por trás do jogo de esconde-esconde, a autora estimula o leitor a pensar no problema.

O jogo que permite a abertura e fechamento das abas fornece à criança a aprendizagem na distinção entre o dentro e o fora. As abas também são usadas como estratégia para se esconder uma resposta, um instrumento na aprendizagem de leitura. Esconder a resposta serve de estímulo para a criança tentar adivinhar o que está lendo e confirmar a resposta escondida (PERROT, 1987).

O jogo de imagens é aplicado ao livro que utiliza a imagem como elemento estrutural. Geralmente, caracteriza-se pela ausência de texto e pela narrativa linear acentuada. 

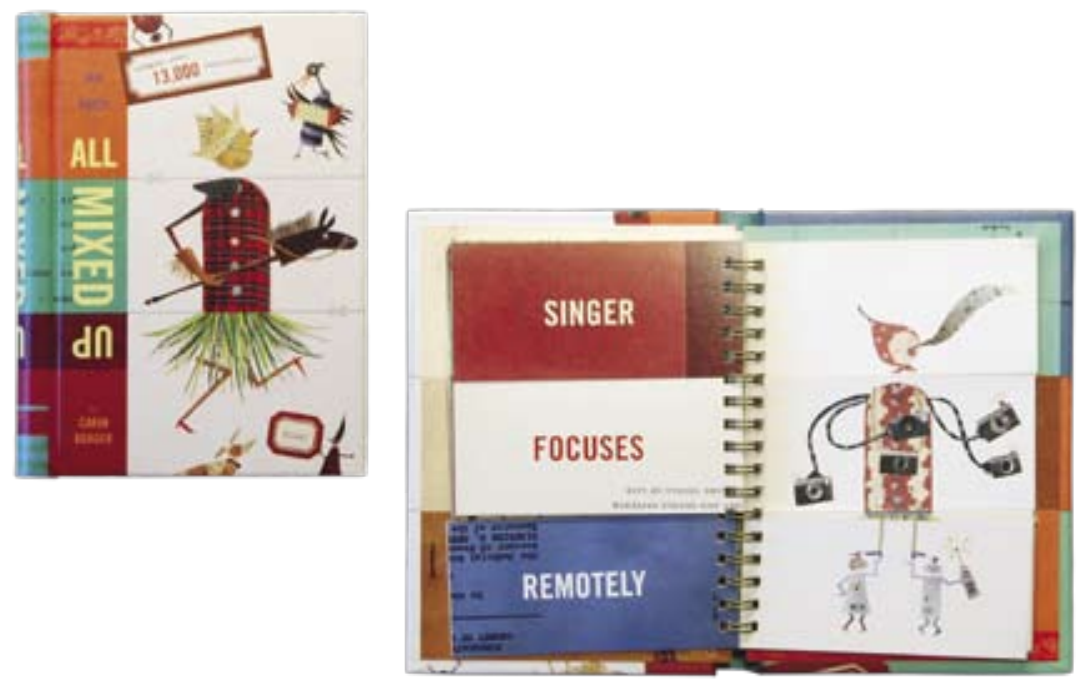

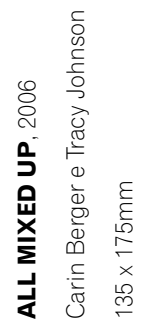

A sequência narrativa é imposta pelo ritmo das imagens, pelo formato da folha e dimensões das ilustrações.

$\mathrm{OH}$ ! É uma narrativa visual comandada pela surpresa do desenho, uma nova imagem se forma ao abrir a folha dobrada. Um livro-objeto sem texto, cuja única dica para adivinhar o que virá é a própria ilustração.

O jogo se torna mais surpreendente quando as regras são rompidas, permitindo à criança a transgressão do senso comum. Quando a simples repetição narrativa é quebrada por uma surpresa, a atenção e a concentração do leitor se manterão (PERROT, 1987).

Em All mixed up, o jogo consiste na permuta de partes do desenho, cabeça, tronco e pernas. O leitor é convidado a formar novos desenhos pela mistura dos personagens, formando desenhos cômicos e frases inusitadas. Além das roupas, o autor brinca com a diferença de gêneros, tipos físicos e faixas etárias, bem como com o sujeito, o verbo e o advérbio.

O jogo com recortes é um dos instrumentos interativos mais antigos encontrados em livros infantis. Os recortes, geralmente, envolvem projetos gráficos mais sofisticados, utilização de facas especiais, preocupação com acabamento e a dinâmica de encadernação. Este instrumento lúdico está presente em quase todos os livros-objeto, sendo seu uso aplicado a diferentes propósitos.

Em Peter Rabbit: a Lucky escape, há uma mistura de instrumentos lúdicos, abas que escondem personagens, roletas que formam novas imagens, encartes dobrados e popup. Todas as páginas deste livro possuem uma manipulação escondida e outra explícita, de forma a estimular a curiosidade do leitor.

O livro-jogo brinca com a expectativa do leitor, ora revelando, ora deixando uma pequena interrogação. A charada estimula simultaneamente o raciocínio e a diversão. Este tipo de surpresa desencadeada no livro trabalha a ansiedade e proporciona prazer à criança. A surpresa é sempre seguida da satisfação (PERROT, 1987).

O Reizinho das Flores, com um projeto gráfico inovador, utiliza o recorte como elemento estruturador, de forma a evidenciar o protagonista e suas qualidades: rei e sozinho. 

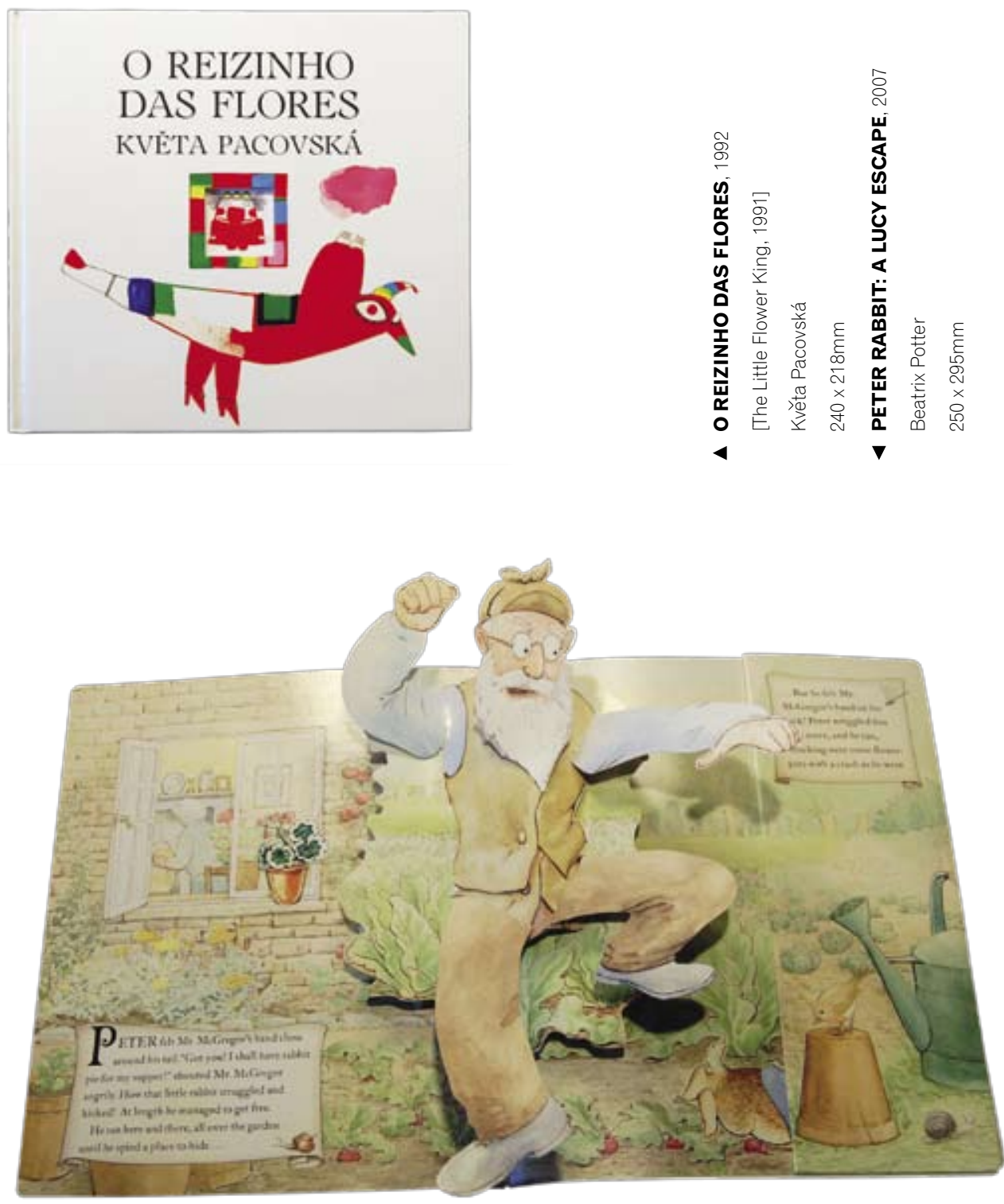

A janela da capa é seguida pelas páginas do miolo, o vazado destas participa da narração e comanda a diagramação.

O livro-jogo reduz o clima austero dos livros infantis tradicionais. Seu propósito é o relaxamento e a descontração proporcionada durante a sua leitura. O jogo trabalha ainda o tempo da narrativa. O livro pode ser lido de frente para trás ou vice-versa apresentando mensagens distintas num mesmo livro. O leitor é convidado a refletir sobre a linearidade narrativa por meio da manipulação (PERROT, 1987).

O livro-brinquedo, o livro-jogo, o livro lúdico e o livro-objeto são, aqui, igualmente entendidos como um objeto de interação espontânea do leitor. 
O design de livro é uma arte que tem suas próprias tradições e um corpo relativamente pequeno de regras aceitas. Se o design de um livro irá chamar atenção ou não para si mesmo, isso vai depender do grau de consciência do leitor acerca tanto do design em geral quanto do design de um livro particular (HENDEL, 2003, p.1).

O projeto gráfico do livro é composto: da escolha correta do tipo, da composição dos elementos na página, do substrato e do cálculo da quantidade de páginas.

\footnotetext{
No desenvolvimento de um projeto gráfico, portanto, deve-se levar em conta tanto questões técnicas quanto a função estética dos elementos envolvidos (forma, tipologia, cor etc.). Isso se aplica tanto ao miolo (escolha adequadas de famílias, fontes, tipos e entrelinhamentos, de acordo com a especificidade da obra) quanto à capa do livro (que deve ser visualmente agradável e coerente com o conteúdo da obra)" (ARAÚJO, 2008, p. 277).
}

Quando o design do livro se apresenta de forma adequada ao que se propõe, este passa despercebido ao leitor. Contudo, quando é ineficiente, torna-se fácil de detectar e dificulta a leitura. $O$ trabalho do designer de livros é descobrir como colocar uma letra ao lado da outra de modo que as palavras do autor fiquem claras ao leitor (HENDEL, 2003).

A diferença entre um livro tradicional e um livro-objeto é a forma como se aplicam os fundamentos de design. O livro-objeto exige um projeto diferenciado, pois a ilustração está mais presente do que a massa de texto. Escolhas como o formato, disposição das informações, representação das imagens e produção gráfica são a base para entender a diferença no design.

O formato caracteriza o aspecto físico do livro-objeto. A proporção adotada está relacionada ao substrato que receberá o impresso, visando à redução de material desperdiçado. Quando se pensa no formato do livro, tem-se como premissa a usabilidade do objeto livro, como este será manipulado pelo leitor. 
O uso da tipografia no livro infantil é peculiar a cada caso, por isso esta pesquisa esboça um quadro geral sobre o tema, trabalhando o panorama da tipografia neste tipo de livro e sua aplicação na atualidade. Muitas das teorias utilizadas aqui têm o livro tradicional como modelo, o objetivo, contudo, é entender como o tipo é apresentado no projeto gráfico de um livro-objeto infantil.

Uma página de livro é composta, predominantemente, por texto e imagem, e as informações podem ser organizadas por meio de malha ou não. Há diversos caminhos para o desenho desta estrutura, desde modelos medievais aos modernistas. No livro-objeto infantil, normalmente, encontra-se uma malha diferenciada para as ilustrações, separada da malha do texto.

A linguagem visual da ilustração define o ritmo narrativo, bem como o estilo gráfico. Diferentes técnicas são utilizadas para ilustrar um livro: aquarela, acrílico, óleo, pastel, nanquim, colagem, digital e técnicas mistas. Independente da técnica aplicada, a ilustração no livro-objeto obedece aos princípios da linguagem gráfica, metodologicamente, classificados em: cor, forma, textura e proporção.

Nos processos de produção gráfica, encontra-se grande parte dos instrumentos que propiciam o livro lúdico, ao permitir que se explore a tridimensionalidade do objeto livro. Apesar de ser a parte final na produção do livro, esta etapa deve ser planejada desde o começo, junto ao primeiros esboços.

\section{FORMATO}

O formato, a capa e a embalagem criam uma expectativa no leitor, uma prévia do que ele encontrará na narrativa, bem como o tamanho do livro expressa a ação: dos livros pequenos se espera uma narrativa mais sutil e meiga, formatos menores transmitem charme e delicadeza, ao contrário dos formatos maiores. Nodelman (1988) explica que uma mesma imagem, mantendo-se o tamanho e dispondo-a em campos diferentes, muda a expressão da narrativa. Por exemplo, uma imagem em um campo maior expressa uma atividade mais intensa.

O formato é determinado pela relação entre a altura e a largura da página (HASLAM, 2007). Os formatos padrões, nos livros, são três: retrato, formato cuja altura da página é maior que a largura; paisagem, formato cuja altura da página é menor que a largura; e quadrado. Os formatos que fogem do padrão permitem dispor as imagens de forma não usual, gerando diferentes respostas.

Livros estreitos, ou livros que utilizam apenas um dos lados da dupla, possuem menor oportunidade de explorar a descrição no fundo. Consequentemente, os desenhos são repletos de informações sem respiro, o que acarreta em imagens confusas e desinteresse do leitor.

Quando se projeta o formato de um livro, deve-se levar em conta uma proporção conveniente à leitura e ao manuseio, além da viabilidade econômica. Um guia de bolso, por exemplo, tem que caber no bolso, já um atlas de mesa, exige um formato maior para que os detalhes das imagens possam ser lidas. Ao projetar um livro, há que se prever a forma de seu manuseio, se ele será segurado com uma mão ou ficará em cima de uma mesa (TSCHICHOLD, 2007). 
Os designers se orientam para escolher o formato de acordo com alguns estudos de proporção existentes, entre os mais conhecidos: a secção áurea e a série Fibonacci. Alguns artistas, arquitetos e designers consideram a seção áurea como símbolo de beleza, ao associar os elementos da natureza com tal relação. Assim, a seção áurea é conhecida como beleza natural (HASLAM, 2007).

Jan Tschichold (1902-1972), tipógrafo alemão, dedicou muitos anos de sua vida à análise de livros e manuscritos ocidentais e descobriu que muitos deles foram impressos em formatos que seguiam a seção áurea. O retângulo da seção áurea pode ser dividido de modo que a relação entre o lado menor e o maior seja de 1:1,61803.

Para formar um retângulo de seção áurea a partir de um quadrado, este é dividido ao meio. A diagonal do meio-quadrado é girada para o lado, definindo o comprimento do retângulo. Na espiral logarítmica, a relação entre o quadrado e o retângulo áureo é constante. Cada quadrado relaciona-se ao seguinte, como parte da série de Fibonacci.
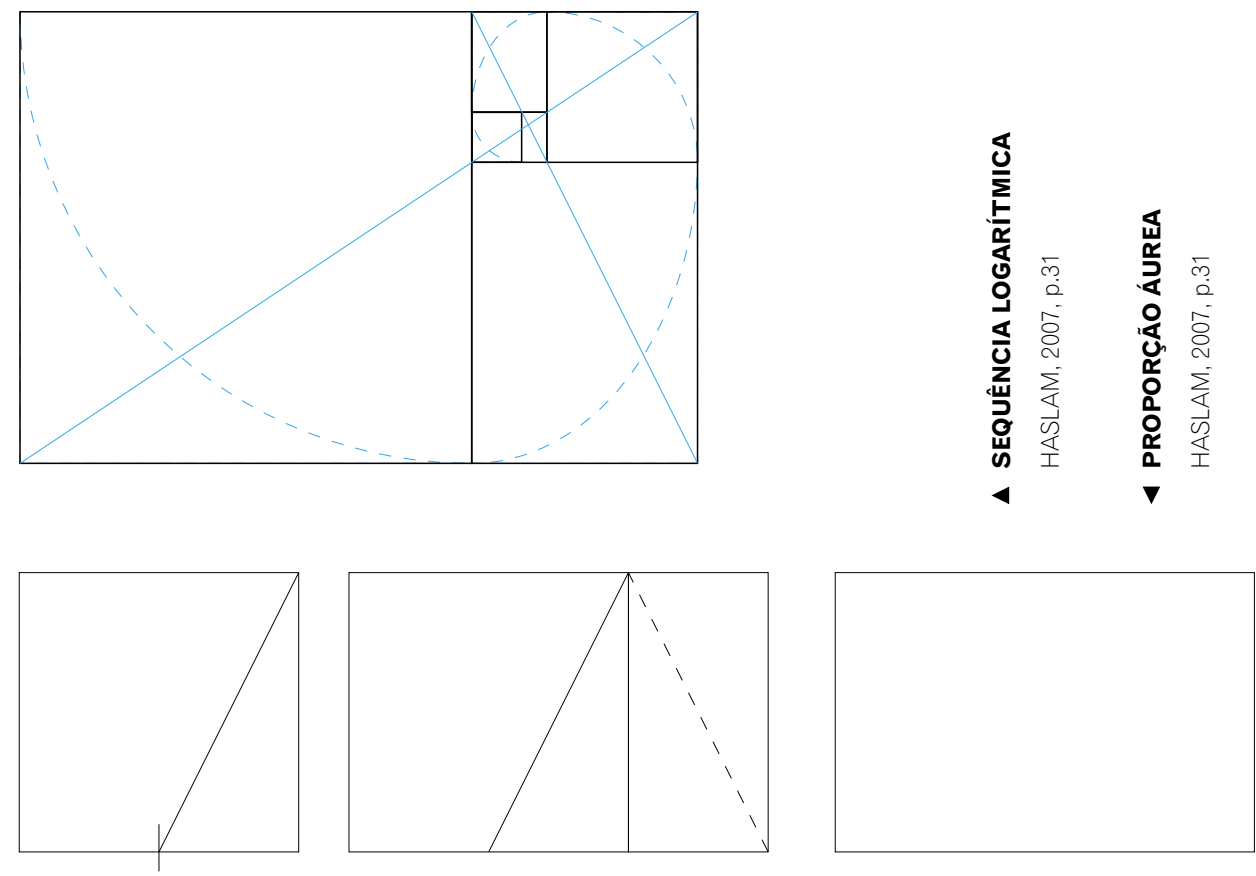

As proporções de páginas claras e intencionais são as definidas geometricamente, obedecendo a uma das razões 1:1,618, 1:1,732, 1:1,414, 1:1,538, as chamadas proporções irracionais, ou 1:2, 2:3, 5:8, 5:9, proporções racionais. As demais relações, Tschichold (2007) considera obscuras e acidentais.

As razões de frações de números racionais produzem os retângulos estáticos, enquanto as frações de números irracionais resultam em retângulos dinâmicos. Os retângulos estáticos quando divididos não fornecem superfícies visualmente atraentes. Por outro lado, os retângulos dinâmicos, ao serem divididos, produzem uma série de divisões harmoniosas em termos visuais (ELAM, 2010). 


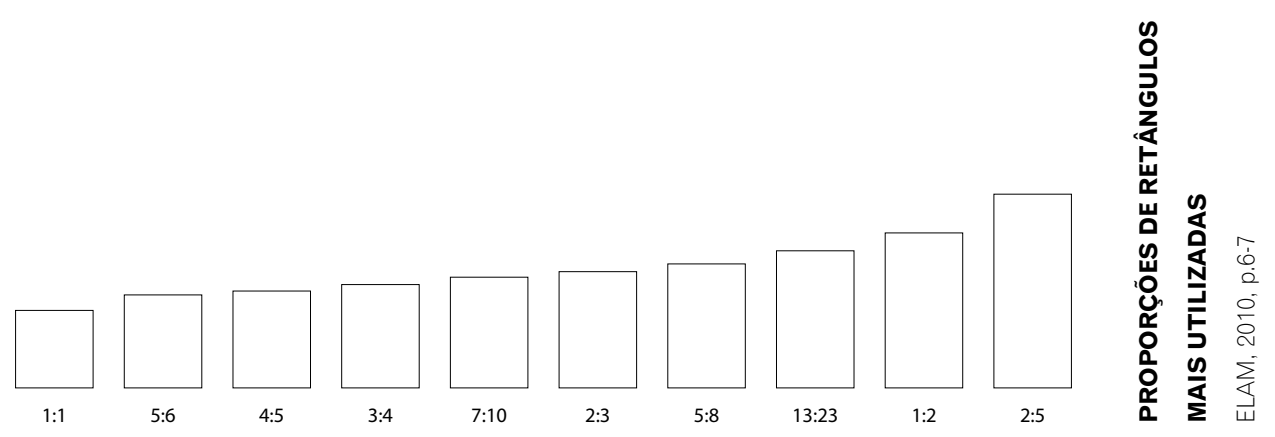

A decisão do formato deve ainda levar em conta o tamanho do substrato e o número de dobras quando impressas em papel. Conhecer os formatos disponíveis no mercado evita desperdício de material. No caso do papel ou do cartão, o designer projeta de forma a obter o melhor aproveitamento por folha impressa. A adequação do projeto ao aproveitamento significa uma economia expressiva nos custos de produção.

\begin{tabular}{lll}
\hline FORMATOS & FORMATO & NÚMERO \\
MAIS COMUNS & DA RESMA & DE PÁGINAS/ \\
DE LIVROS & DE PAPEL & APROVEITAMENTO \\
\hline $16 \times 23 \mathrm{~cm}$ & $66 \times 96 \mathrm{~cm}$ & 32 (16 cada lado) \\
\hline $14 \times 21 \mathrm{~cm}$ & $87 \times 114 \mathrm{~cm}$ & 64 (32 cada lado) \\
\hline $21 \times 28 \mathrm{~cm}$ & $89 \times 117 \mathrm{~cm}$ & 32 (16 cada lado) \\
\hline $12 \times 18 \mathrm{~cm}$ & $76 \times 112 \mathrm{~cm}$ & 64 (32 cada lado) \\
\hline $17 \times 24 \mathrm{~cm}$ & $72 \times 102 \mathrm{~cm}$ & 32 (16 cada lado) \\
\hline
\end{tabular}

A padronização no formato de folha para gráfica, estabelecida em 1975, pela Organização Internacional de Normalização, é adotada pela ABNT - Associação Brasileira de Normas Técnicas. Este padrão normatiza o retângulo cujos lados medem 841 x 1189mm em A0, derivando os múltiplos da série A (ARAÚJO, 2008). A derivação da série A segue as proporções do retângulo de raiz 2, aproximando-se das propriedades estéticas da seção áurea (ELAM, 2010).

Formatos ISO de papel são conhecidos como série A, em que o AO equivale a um metro quadrado. A proporção entre o lado maior, a diagonal do quadrado, e seu lado menor, é igual a 1,414. Todas as folhas da série $A$ são múltiplos e submúltiplos do formato A0, obtidos sempre dividindo-se ao meio. Esta série vai do A0 ao A12.

O formato B é uma série complementar ao formato A, mantendo a mesma proporção e o princípio de que cada formato seguinte corresponde à metade do formato anterior. $\mathrm{O}$ formato $\mathrm{C}$ foi concebido primeiramente para impressos padronizados e compartilha os formatos comuns com A e B. 


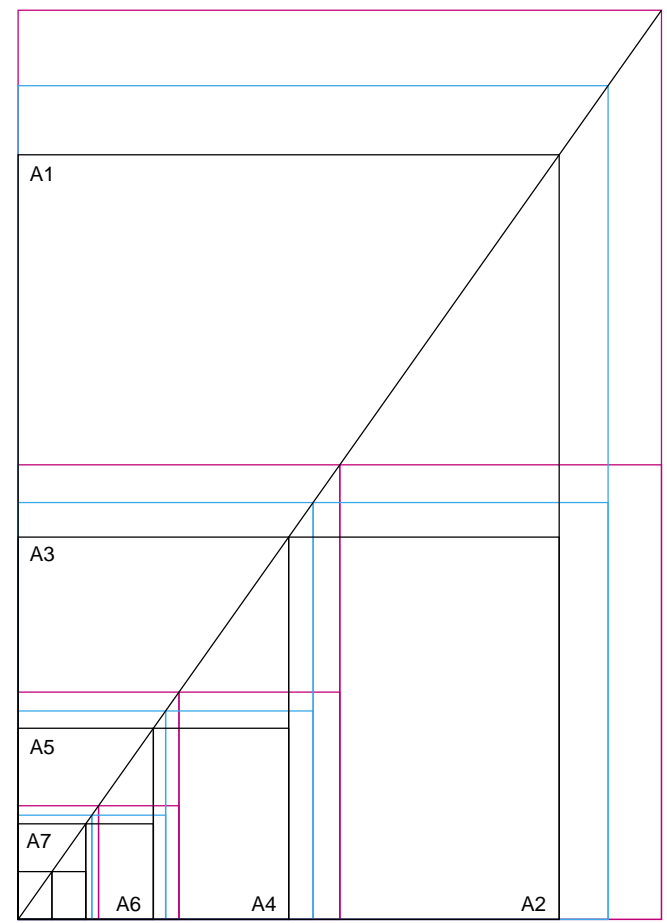

série A

A0 $841 \times 1189 \mathrm{~mm}$

A1 $594 \times 841 \mathrm{~mm}$

A2 $420 \times 594 \mathrm{~mm}$

A3 $297 \times 420 \mathrm{~mm}$

A4 $210 \times 297 \mathrm{~mm}$

A5 $148 \times 210 \mathrm{~mm}$

A6 $105 \times 148 \mathrm{~mm}$

A7 $74 \times 105 \mathrm{~mm}$

A8 $52 \times 74 \mathrm{~mm}$ série $B$

B0 $1000 \times 1414 \mathrm{~mm}$

B1 $707 \times 1000 \mathrm{~mm}$

B2 $500 \times 707 \mathrm{~mm}$

B3 $353 \times 500 \mathrm{~mm}$

B4 $250 \times 353 \mathrm{~mm}$

B5 $176 \times 250 \mathrm{~mm}$

B6 $125 \times 176 \mathrm{~mm}$

B7 $88 \times 125 \mathrm{~mm}$

B8 $62 \times 88 \mathrm{~mm}$

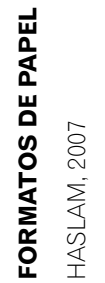

série $\mathbf{C}$

C0 $917 \times 1297 \mathrm{~mm}$

C1 $348 \times 917 \mathrm{~mm}$

C2 $458 \times 348 \mathrm{~mm}$

C3 $324 \times 458 \mathrm{~mm}$

C4 $229 \times 324 \mathrm{~mm}$

C5 $162 \times 229 \mathrm{~mm}$

C6 $144 \times 162 \mathrm{~mm}$

C7 $81 \times 114 \mathrm{~mm}$

C8 $57 \times 81 \mathrm{~mm}$

Os formatos norte-americanos são expressos em polegadas, papéis para artigos de papelaria são baseados em múltiplos de 81/2 × 11 polegadas, enquanto outros formatos são usados para papéis de livros (HASLAM, 2007).

No Brasil, os formatos mais utilizados são AA, cuja folha mede $760 \times 1120 \mathrm{~mm}$, para livros infantis ou obras impressas em colunas. Este formato permite imprimir 64 páginas de um livro 190 × 270mm (ARAÚJO, 2008).

Por outro lado, o formato mais disponível nas gráficas é o BB, 660 ×960mm. Quando se calcula o aproveitamento de papel, Villas-Boas (2008) recomenda considerar o formato BB.

O formato do livro, por fim, deve levar em consideração o conteúdo. Se for um livro de arte, as imagens justificam sua forma mais larga. O formato quadrado da página, segundo Shulevitz (1997), é a forma mais dinâmica, pois sugere uma ação circular, por permitir um 

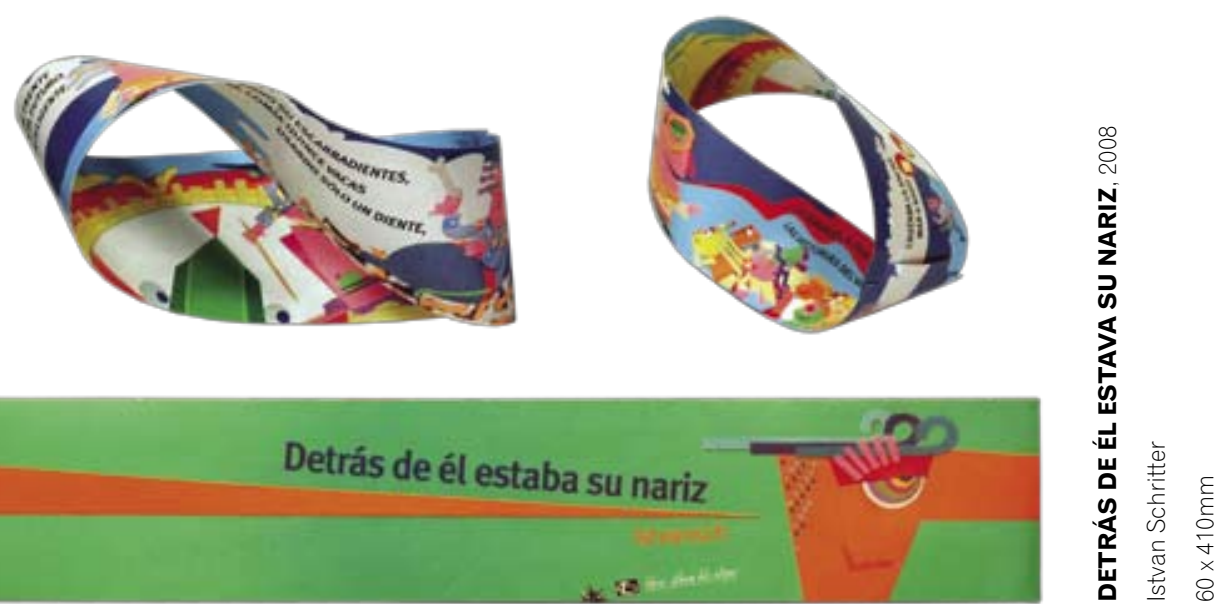

encaixe perfeito da circunferência. O quadrado também fornece a percepção de uma escala reduzida, menor do que o real.

Alguns formatos em livros-objeto não derivam de nenhuma relação conhecida, sua intenção artística direciona o projeto a uma forma inusitada. No entanto, o formato mais utilizado nos livros contemporâneos ainda é o retrato.

Istvansch utiliza a fita de Möbius, nas dimensões $60 \times 410 \mathrm{~mm}$, para estruturar o livro-objeto Detrás de él estava su nariz. A sequência narrativa, ilustradas com a técnica de recorte de papel, só pode ser totalmente compreendida quando as tiras são montadas. Cada uma das sete fitas contém uma história fechada nela mesma, que começa e termina no mesmo ponto.

\section{TIPOGRAFIA}

No século XIX, uma página de texto era, rotineiramente, composta como um bloco rígido formado por tipos de chumbo, algumas vezes quebrado por uma capitular decorada ou pelo espaço destinado para a ilustração. Os livros ilustrados e os livros de alfabetização, embora com formas gráficas mais estimulantes, usavam uma tipografia neutra para não distrair a criança.

Os primeiros experimentos nos layouts de livros infantis se deram na revolução modernista, com El Lissitzky em Of Two Squares, de 1922. Neste livro, aparecem somente formas simbólicas abstratas, que El Lissitzky chamou de meios elementares, no lugar dos dispositivos de representação narrativa. Sua intenção era a participação da criança num jogo eletrizante de construção da história por meio de papéis e adesivos (HELLER, 2007).

No final da década de 1930, o design do livro infantil foi influenciado pela "Nova Tipografia", tipografia defendida pela Bauhaus, sob a forma de fontes sem serifa e composições assimétricas. Entre 1940 e 1950, alguns encontros foram realizados no Instituto 

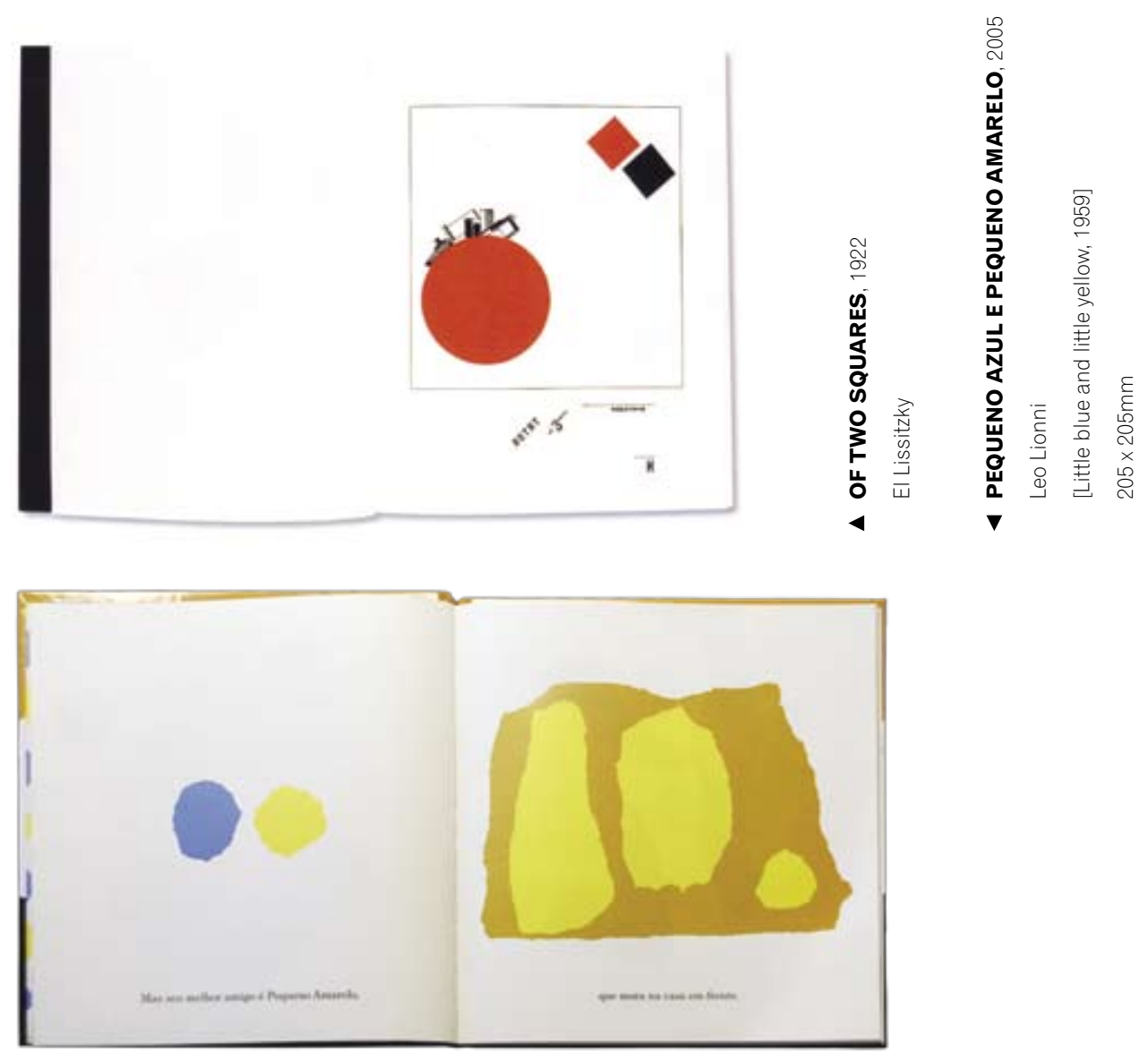

Americano de Artes Gráficas, quando se convencionou alguns padrões de legibilidade para os livros infantis, padrões que passaram a ser adotados pela maioria das editoras. Os livros ilustrados eram, geralmente, compostos com tipos clássicos, como por exemplo Jason, Garamond, Akzidenz e Grostesque, tipos que raramente se integravam com a arte (HELLER, 2007).

Nos livros infantis, da década de 1950 até a década de 1980, o design foi bastante ofuscado pelo desenvolvimento da arte. Mesmo os artistas progressistas mantinham uma postura conservadora quando se tratava de tipografia, os mais de quarenta livros de Leo Lionni, por exemplo, foram impressos em Century Schoolbook, defendendo que o elemento essencial de um livro ilustrado é a imagem, não o tipo (HELLER, 2007). Leo Lionni (1910-99), ilustrador ítalo-americano, vencedor de quatro prêmios Caldecott Honor Book, é autor de vários livros para crianças, elaborados em diferentes técnicas e estilos. O livro, O pequeno azul, um clássico, inova a forma de narrar com formas abstratas.

A situação começou a mudar na década de 1980, quando o design do livro infantil se torna mais integrado, à medida em que o autor/ilustrador passa a ter participação mais ativa no processo de design. O computador forçou uma ampla reavaliação dos princípios tipográficos em toda a mídia impressa (HELLER, 2007). 
Os tipos digitais representaram um grande avanço para a composição da página impressa, a página diagramada passou a ser produzida em menor tempo e com maior precisão. O meio digital permitiu, ao designer, explorar as fontes: manipular e distorcer a letra, bem como criar famílias tipográficas mais adequadas ao tema do material diagramado (HASLAM, 2007).

A manipulação da fonte é vista por Tschichold (2007) como um meio de o projeto gráfico sair do lugar-comum, mas o autor considera este artifício um erro de projeto, caso tal inovação destrua a legibilidade e não permita o rápido reconhecimento das letras impressas. Tschichold defende, ainda, o uso da tipografia tradicional.

As escolhas do projeto tipográfico de um livro são direcionadas pelo tamanho da fonte, espaço das entrelinhas e família de tipos. Este conjunto de critérios associados permite desenhar a massa tipográfica da página. A forma dessa massa, o tamanho das caixas de texto e o comprimento dos parágrafos, bem como sua distribuição, influencia o conjunto visual.

A escolha da tipografia pauta se na disponibilidade de pesos dentro de cada família, de acordo com as necessidades do texto a ser diagramado. Questões de legibilidade também são levadas em conta, assim como o volume editorado, o que para as editoras se traduz em custo.

Hulburt (1986) esclarece que a ilegibilidade pode iludir o leitor. Não há dúvidas da importância da legibilidade na mensagem, todavia não é o tipo que salvará o texto, caso este seja enfadonho, o livro não será lido mesmo num corpo de alta legibilidade. O autor afirma que a melhor solução é usar a tipografia de tal forma que consiga construir um convite à leitura.

Segundo Araújo (2008), alguns fatores prejudicam a legibilidade e devem ser evitados pelos designers: composição de maiúsculas em itálico, determinadas combinações de letras que provocam junções; linhas com tipos de olhos estreitos e curvas fechadas ou linhas curtas com tipos de olho amplo e de curvas abertas; caracteres miúdos com hastes descendentes e ascendentes muito longas ou muito curtas que, resultem em brancos entre as linhas.

Os textos de um livro recebem uma hierarquia visual constituída pelo espaço, cor e corpo. O destaque na massa de texto, no livro tradicional, serve para distinguir os títulos, as notas e as legendas. Estes recebem, normalmente, tratamento diferenciado, pelo tamanho do corpo ou pelo tipo, de forma a promover tal destaque na página diagramada. No caso do livro infantil, a hierarquia quase não é necessária. Os recursos gráficos para destacar palavras são mínimos.

No livro-objeto infantil, pela própria característica do texto, a massa tipográfica é reduzida ou quase inexistente. Em muitos livros-objeto, a tipografia aplicada é experimental, produzida manualmente pelo artista, e em alguns casos, não obedece a nenhuma regra.

Segundo Rocha (2002), a tipografia experimental está ligada ao que se costuma chamar de design de autor, em que o designer expressa sua visão no trabalho. $\mathrm{O}$ autor faz ressalva ao uso da palavra "experimental", que alguns designers utilizam para desculpar trabalhos mal acabados, sob a justificativa da inovação. Por outro lado, o experimentalismo pode ampliar possibilidades singulares. "A mistura de estilos, distorções óticas, caligrafias inusitadas e todo tipo de variações geométricas são alguns dos caminhos" (ROCHA, 2002, p.53).

Se por um lado a tipografia artesanal agrega valor estético à obra pela especificidade, por outro inviabiliza a reprodução em diversas línguas com a mesma qualidade. Bob 

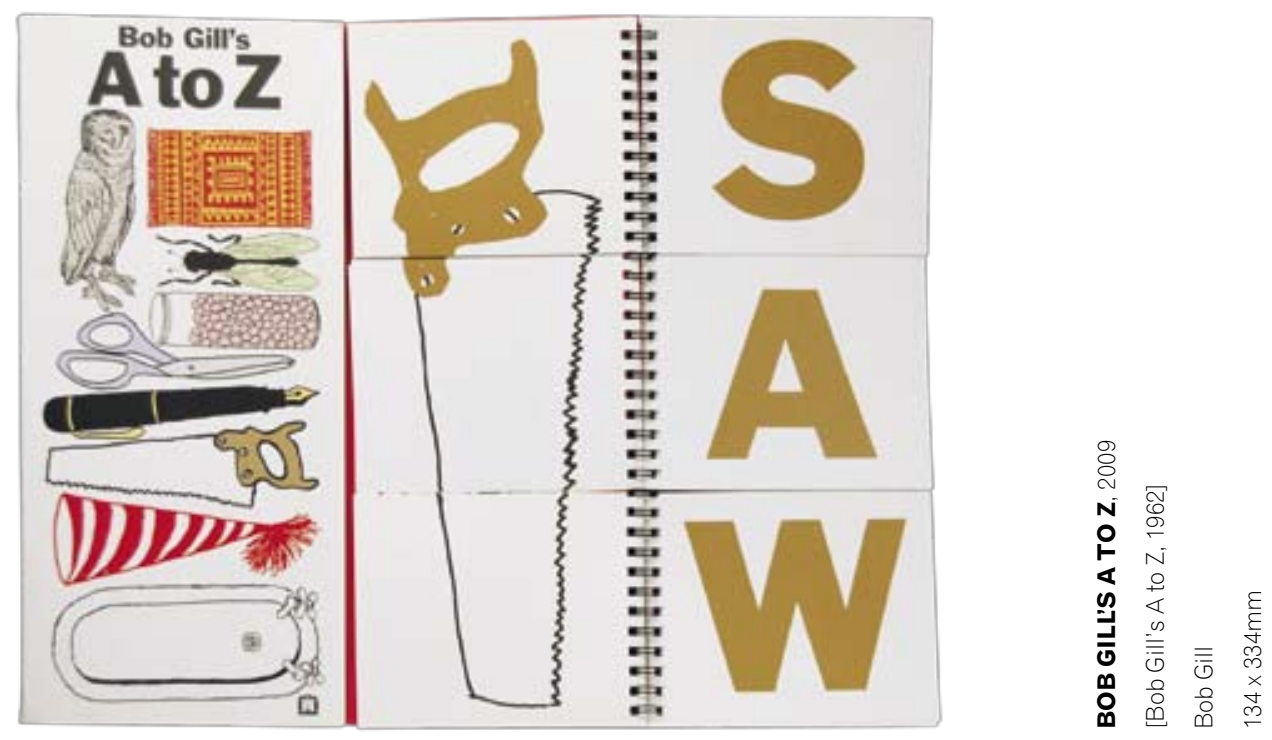

Gill's $A$ to $Z$ é um livro-objeto que brinca com a permuta de lâminas recortadas e unidas pela encadernação wire-o. Um lado da página é destinado à imagem e outro à palavra, propondo ao leitor adivinhar a palavra de 3 letras correspondente à figura. Cada palavra é escrita de forma diferenciada, por tipo e cor, estabelecendo uma relação entre texto e ilustração. Neste caso, a reprodução em outro idioma torna-se inviável.

\title{
ORGANIZAÇÃO DA PÁGINA
}

\begin{abstract}
A informação visual comunica de modo não verbal, por meio de sinais e convenções que podem motivar, dirigir ou mesmo distrair o olhar do leitor, e todos os elementos visuais influenciam uns aos outros. Por isso, o projeto visual de um livro é uma ferramenta importante para comunicação, e não apenas elemento decorativo. O modo como se organiza a informação numa página pode fazer a diferença entre comunicar uma mensagem ou deixar o usuário confuso. (ARAÚJO, 2008, p. 373)
\end{abstract}

A organização da página está diretamente relacionada com seu formato. A partir dele, o designer projetará uma malha estrutural que hierarquize a posição das imagens e do texto. Os elementos de composição referem-se à relação texto-imagem ou imagem-imagem.

A grade (grid), ou malha, ou grelha, corresponde às proporções internas da página, seu desenho estabelece a organização do conteúdo. Os sistemas básicos de grade determinam as larguras das margens, as proporções da mancha gráfica e a localização dos elementos que se repetem no layout.

O princípio de grelhas de Brockmann é a principal referência de organização gráfica desde a Bauhaus. Este autor defende o uso da grelha como processo projetual, de forma a obter uma organização racional. 
Um tal sistema de ordenação obriga o desenhista a ser honesto no uso dos recursos do desenho. Exige que ele se adapte ao problema que tem entre mãos e que o analise. Favorece o pensamento analítico e dá à solução do problema uma base lógica do material. Se o texto e as imagens são ordenadas sistematicamente, mais claramente ressaltam as prioridades." (BROCKMANN, 1982, p.12)

Samara (2007, p.9) define a grade tipográfica baseada no Estilo Internacional como "um sistema de planejamento ortogonal que divide a informação em partes manuseáveis. O pressuposto desse sistema é que as relações de escala e distribuição entre os elementos informativos - imagens ou palavras - ajudam o observador a entender seu significado."

A chave criativa para os diagramas é a relação cuidadosa entre as divisões horizontais e verticais e como estas se relacionam no aspecto global do design. Hulburt (1986, p.82) afirma que,

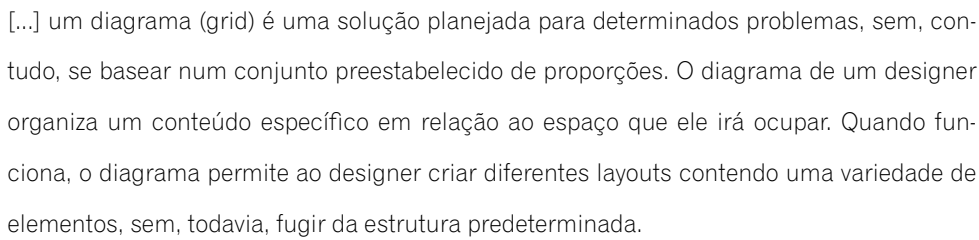

Quanto mais complexa a grade desenhada mais ela terá possibilidades de exploração, o que representa maior variação nos tamanhos das imagens. Um livro pode, ainda, apresentar mais de uma grade, resolvendo problemas de diagramação com diferentes graus de informações como: índice, texto, bibliografia, legenda.

A grade tipográfica (SAMARA, 2007) é um princípio organizador no design gráfico cuja influência está arraigada na prática diária, e para alguns designers é incontestável no processo de trabalho, oferecendo precisão, ordem e clareza. Para outros designers, porém, é símbolo de opressão na busca de linguagens expressivas.

O desenho da malha deve levar em conta o tamanho do parágrafo. A largura das frases dita o ritmo de leitura, que corresponde ao movimento ocular que percorre o texto e suas pausas. A maneira como se dispõe os caracteres e as orações fornecerá uma leitura mais ou menos cômoda, podendo até torná-la impraticável (ARAÚJO, 2008).

A construção da página pode ser classificada como simétrica ou assimétrica. Os modelos de páginas simétricas são baseados em construções geométricas, a página da esquerda é imagem espelhada da direita, orientada pelo eixo de simetria.

O método elaborado pelo arquiteto Villard de Honnecourt propõe a divisão geométrica do espaço de qualquer formato de página proposta. Quando usado sobre o formato de seção áurea, divide a altura e a largura da página em nove. As margens são determinadas pela altura e largura da unidade. Esta divisão pode ser usada no formato retrato ou paisagem (HASLAM, 2007). 

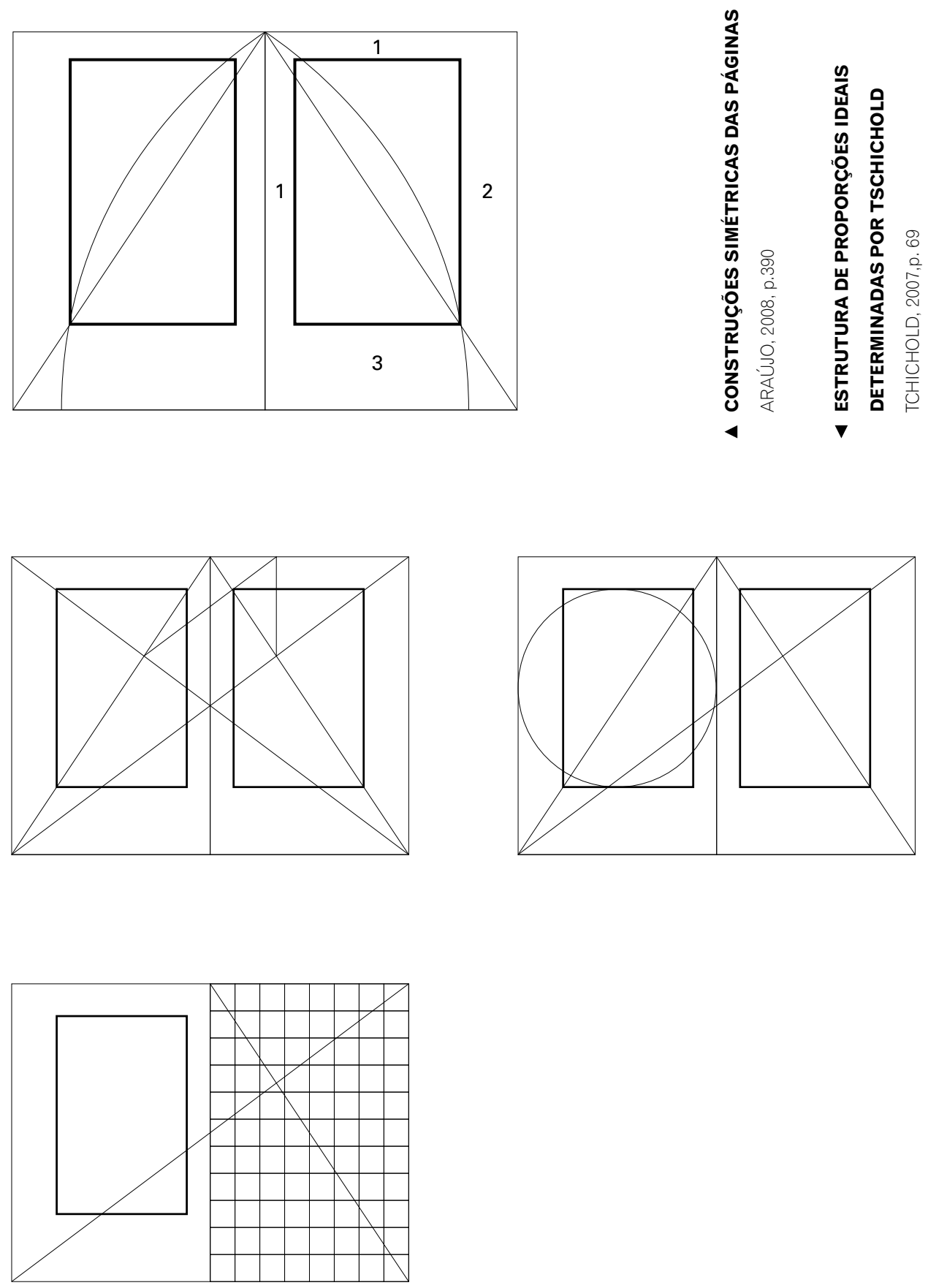
Outra forma de dividir a página é utilizando retângulos que podem ser subdivididos em retângulos menores que retêm as proporções de altura e largura da página original. A largura das margens e a posição das caixas são desenhadas a partir da intersecção entre as diagonais e os círculos, cujos diâmetros são determinados pela largura do retângulo (HASLAM, 2007).
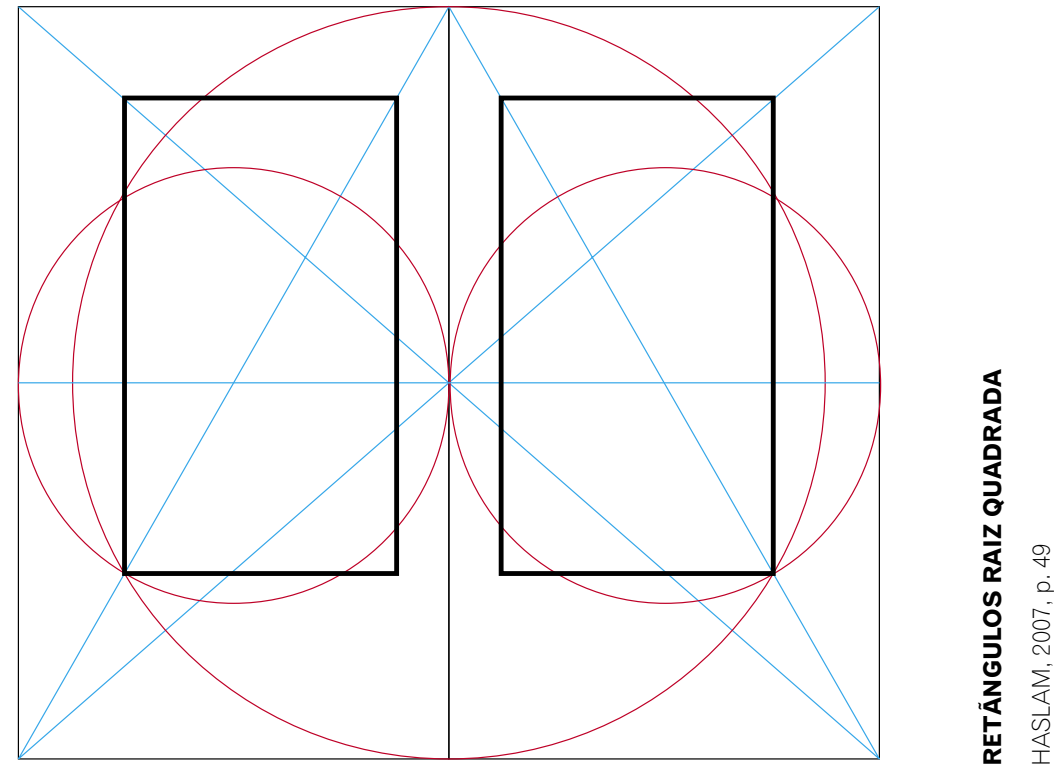

As grades modernistas estão baseadas em princípios racionais, fundamentados por teorias implementadas na Bauhaus. A malha, nestes casos, é desenhada com base na quantidade de colunas que o designer precisa, fazendo-se, posteriormente, ajustes na altura, conforme a fonte escolhida. O sistema estrutural modernista é, portanto, flexível, pois permite que cada página dupla seja diferente, o que garante seu dinamismo.

No livro-objeto infantil, o texto e a imagem não necessariamente estão inseridos na mesma malha. Frequentemente não encontramos nenhuma malha nos livros-objeto, pois as ilustrações são posicionadas de acordo com a hierarquia visual estabelecida caso a caso.

Os exemplos a seguir demonstram diferentes formas de diagramação, com e sem regras estabelecidas. Em O livro foguete, a imagem obedece à mesma proporção clássica da página, orientando a posição do texto pelo buraco, que serve de eixo para o alinhamento e distribuição dos parágrafos e ilustra a passagem do foguete.

A Verdadeira História de Chapeuzinho Vermelho narra uma história diversa da clássica, por meio de diversos recursos lúdicos, como abas, roletas, janelas, encartes e pop-up, incentivando o leitor a explorar as páginas. Neste livro-objeto, a diagramação das páginas não é estabelecida por grades fixas, os textos são distribuídos em pequenas caixas, com alinhamento centralizado, obedecendo à ilustração. 

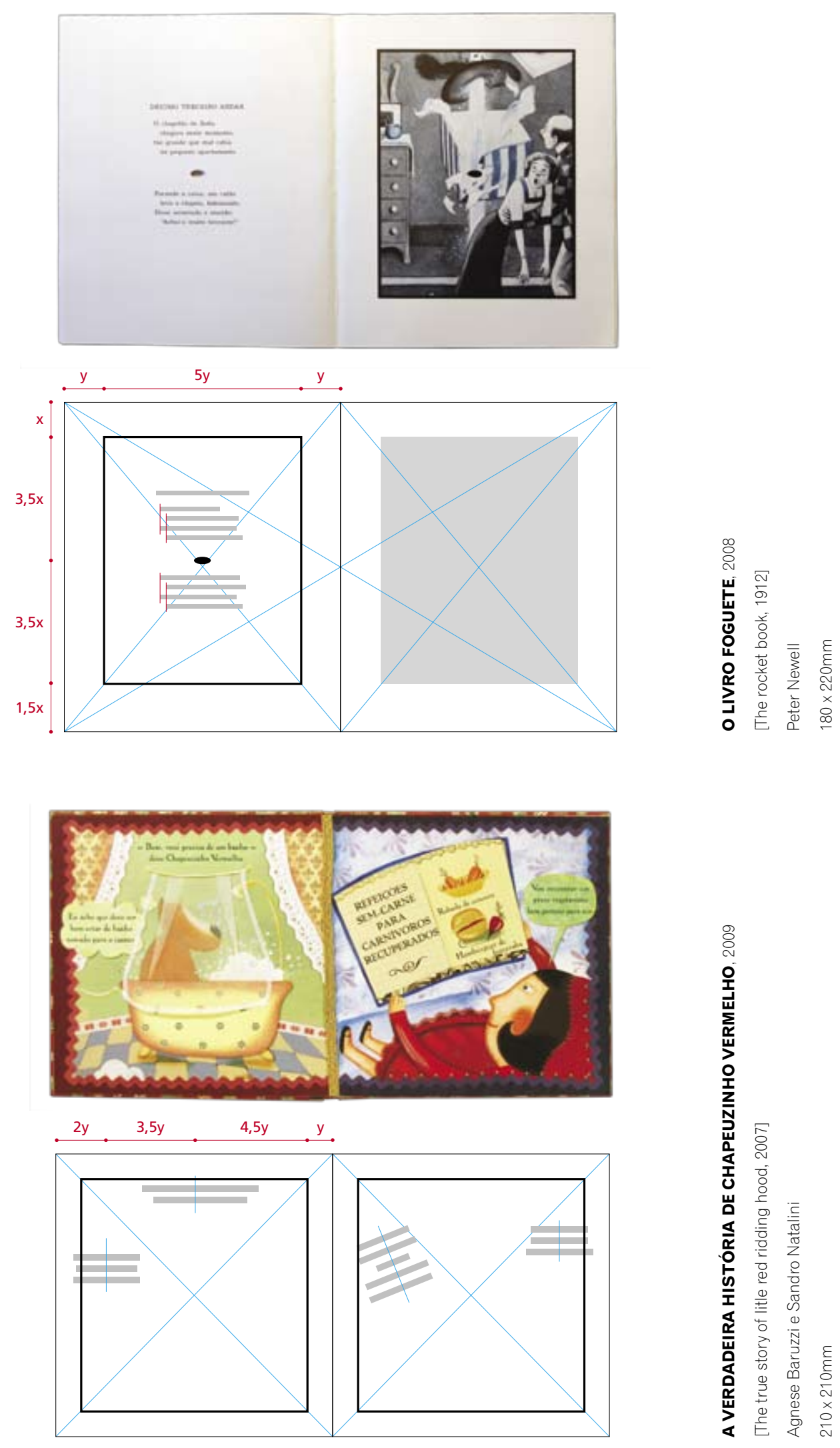


\section{LINGUAGEM VISUAL DAS ILUSTRAÇÕES}

"A linguagem é simplesmente um recurso de comunicação próprio do homem, que evolui desde sua forma auditiva, pura e primitiva, até a capacidade de ler e escrever" (DONDIS, 1997, p.2).

Munari (1997) defende que a linguagem visual deve ser direta e universal, acessível a todas as línguas, por meio de linguagem objetiva. A imagem tem seu caráter comunicativo, não só pelo desenho, mas por tudo que a compõe: a cor, o material, a forma. O seu significado está relacionado, também ao contexto onde é inserida.

Segundo Góes (2005), o livro infantil possibilita experimentar diversas linguagens, que podem ir dos quadrinhos às mídias eletrônicas, extrapolando o físico natural, de encontro à sensibilidade e à percepção. A linguagem visual aplicada no livro-objeto infantil deriva da associação entre a técnica de ilustrar (óleo, pastel, nanquim, lápis, recorte) e a composição dos elementos gráficos (cor, forma, ritmo), esta combinação fornece ao leitor a mensagem visual.

As técnicas de ilustração são inúmeras, cabe ao artista explorar o melhor efeito disponível em cada uma delas. Não se pode afirmar que uma é melhor do que a outra sem que se analise a forma como é empregada. As nuances e sutilezas das imagens são criadas pelo ilustrador. A técnica por si só nunca expressará a mensagem, é apenas um instrumento que facilita a compreensão do tema. (NODELMAN, 1988).

A ilustração pode esclarecer um texto por causa de sua capacidade de comunicação, mesmo quando trabalha apenas com linhas. Para entender uma ilustração, esta deve ter um caráter mais universal, ou seja, usar os códigos universais, pois nem todos os desenhos são compreendidos em todas as sociedades, posto que os signos estão relacionados à cultura (NODELMAN, 1988).

Então, cabe ao ilustrador analisar, junto ao texto, a melhor forma de se explorar cada técnica para que se obtenha um resultado diferenciado. O ilustrador adequa seu estilo à proposta literária, na medida em que desenvolve suas características na busca de novas expressões. Ao contrário de uma obra de arte, a ilustração é elaborada com um conceito narrativo, ou seja, é a interpretação do texto literário na forma de desenhos.

A comunicação do livro só é possível se a mensagem for decifrável (NODELMAN, 1988). No picture book, por exemplo, a sequência das imagens deve estar disposta num sentido lógico para o entendimento, e ser dinâmica a ponto de prender a atenção do leitor. $\mathrm{O}$ sucesso do livro está vinculado à sua clareza narrativa. Para Oliveira (2008), a narrativa visual descreve uma história contada por imagens, mas não necessariamente é a tradução visual de um texto.

Não há regras absolutas para a composição visual, o que existe é um grau de compreensão do que acontece em termos de significado. Dondis (1997) explica que o desenho é criado a partir de inúmeras cores, formas, texturas e proporções relativas, e quando se relaciona estes elementos obtém-se um significado. Este resultado é a composição, a intenção.

A composição é um dos fundamentos da linguagem visual, engloba as imagens, a disposição dos espaços vazios e cheios, a escolha tipográfica e todos os adereços gráficos. 

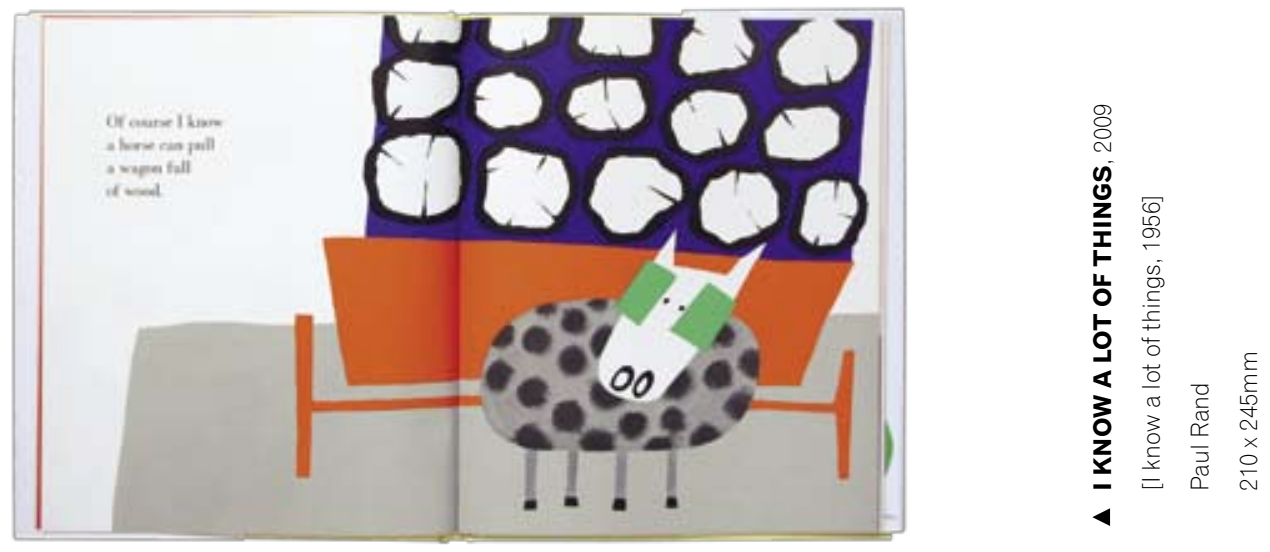

Paul Rand ilustra com a técnica do recorte.

Este autor defende o caráter experimental como expressão da imagem.
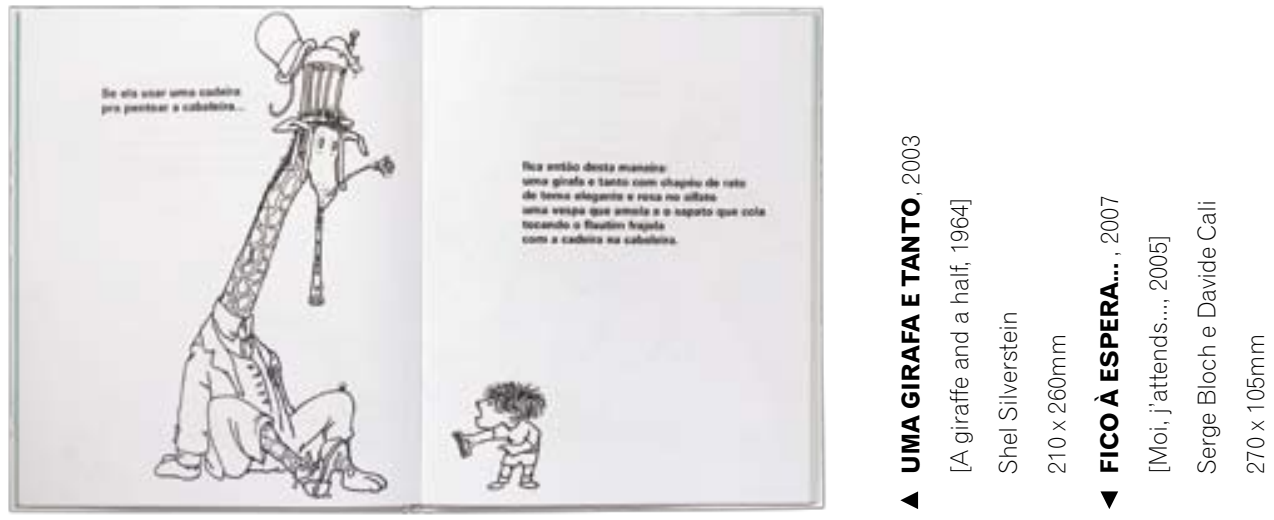

Shel Silverstein tem seus livros caracterizados por uma ilustração a traço, que não utiliza cores ou figuras chapadas.

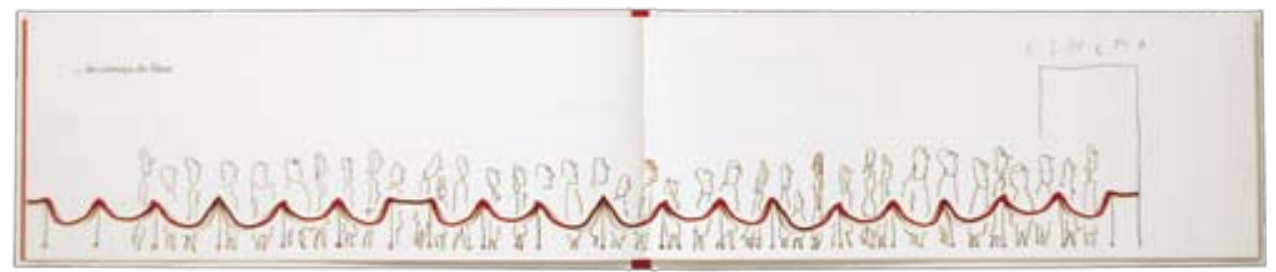

Serge Bloch ilustra por meio da fotografia e do desenho a traço, seus desenhos brincam com a sombra do objeto fotografado, buscando um tom de humor nas imagens. 
O equilíbrio das massas e o peso da imagem estruturam a composição na página, hierarquizando as informações e direcionado o olhar.

Para entender como a composição visual relaciona-se com a ilustração, o estudo a seguir abordará separadamente os principais recursos de linguagem trabalhados na imagem: cor, forma, ritmo, textura, escala, figura-fundo e movimento.

\section{COR}

O uso da cor para o designer tem duas opções de projeto: usar o material já colorido pela indústria ou inserir elementos coloridos no objeto seguindo algum critério (MUNARI, 1997). No caso do livro, por exemplo, o designer tem como escolha o uso do papel colorido ou a impressão em cores.

A cor é um dos elementos narrativos da imagem que possui maior poder emotivo e evocativo. Contudo, isso não lhe dá nenhuma prioridade como recurso de linguagem (OLIVEIRA, 2008). Uma cor não pode ser analisada isoladamente na ilustração, mas com todas as outras cores na composição.

Entende-se o uso intencional da cor quando ela expressa contraste e quantidade de luz e tempo. Apesar da intencionalidade, não existe uma fórmula para a aplicação da cor. A predominância de uma determinada cor na página manifesta uma leitura visual, uma vez que a temperatura da cor pode sugerir proximidade ou distância, associadas, respectivamente, às gamas vermelho-amarelo e azul-verde (DONDIS, 1997).

A escolha da cor pode também estar relacionada às características do artista, sem, contudo desprezar a teoria das cores. Oliveira (2008) explica que existem processos de estudo e de compreensão da cor utilizada pelo ilustrador nos livros para crianças, que são instrumentos de expressão do artista, fruto de uma escolha subjetiva.

\footnotetext{
Além do significado cromático extremamente permutável da cor, cada um de nós tem suas preferências pessoais por cores específicas. Escolhemos a cor do nosso ambiente e de nos sas manifestações. Mas são muito poucas as concepções ou preocupações analíticas com relação aos métodos ou motivações de que nos valemos para chegar a nossas opções pes soais em termos do significado e do efeito da cor (DONDIS, 1997, p.70).
}

Dos processos visuais disponíveis para o designer, a percepção da cor é o mais emocional, ela tem grande apelo expressivo e pode ser usada com muito proveito para intensificar a informação visual. A cor não apenas tem um significado de senso-comum como também um valor informativo específico, que se dá por meio dos significados simbólicos a ela vinculados.

No livro, a cor codifica uma informação. O designer também usa a cor para destacar uma informação, o olhar do leitor pode ser arrastado para um elemento que se distingue do resto da página. "Usar cores com valores contrastantes tende a precisar mais as formas, assim como a combinação de cores de valores próximos suaviza a distinção entre os elementos" (LUPTON; PHILLIPS, 2008, p.74). 

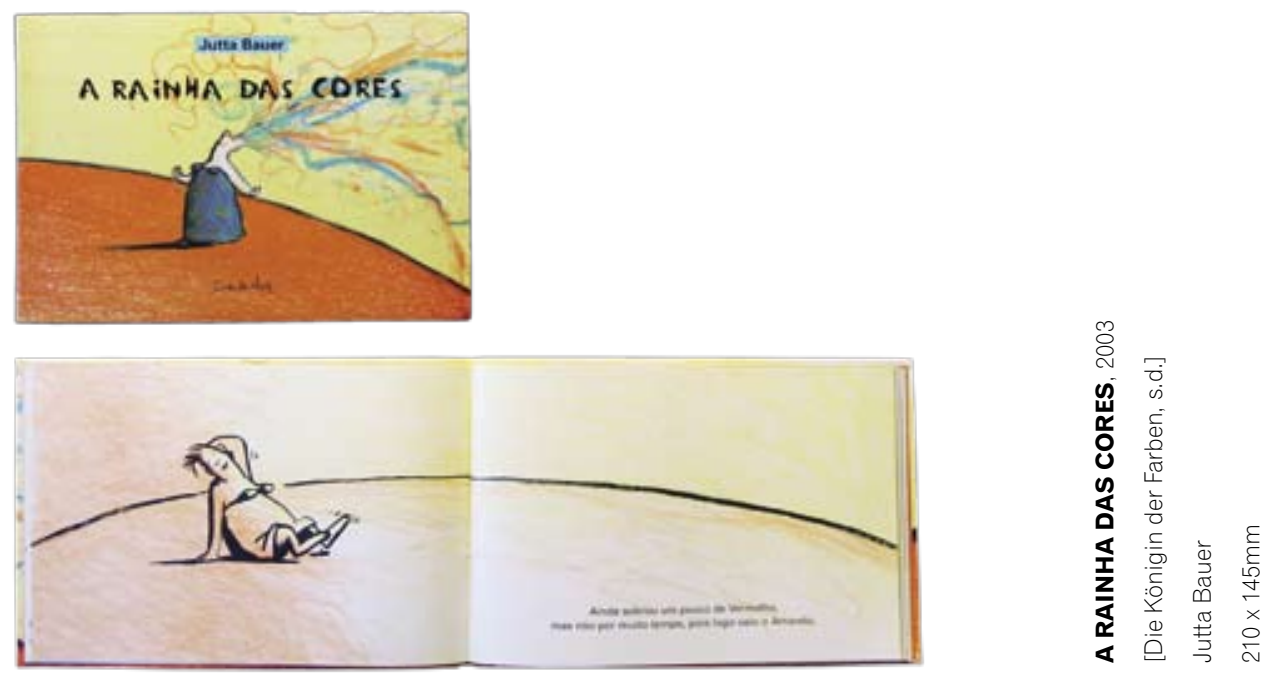

A saturação é outra dimensão da cor, que representa sua pureza. Dondis (1997) explica que a cor saturada é simples, quase primitiva, sendo a preferida pelos artistas e pelas crianças. As cores menos saturadas levam a uma neutralidade cromática, e são associadas ao repouso e à tranquilidade. Quanto mais saturada, mais carregada será sua expressão e emoção. As relações mais comuns associadas às cores e aos sentimentos dos personagens são: o azul para tristeza; amarelo para a alegria; vermelho para amabilidade; verde para crescimento. Os artistas utilizam destas relações para mostrar os sentimentos na cena descrita. Este uso torna-se ainda mais claro quando há o predomínio de uma única cor (NODELMAN, 1988).

Em A Rainha das cores, Jutta Bauer associa o uso das cores ao estado de espírito da protagonista, cada cor descrevendo o sentimento correspondente. O preenchimento da cor através do rabisco a lápis demonstra alguns sentimentos da rainha como solidão e raiva.

\section{FORMA}

Existem três formas geométricas básicas que, combinadas, formam todos os desenhos: o quadrado, o círculo e o triângulo equilátero. Cada uma das formas exerce características específicas, bem como significados de percepção. Dondis (1997) explica que ao quadrado associa-se enfado, honestidade, retidão e esmero; ao triângulo, ação, conflito, tensão; ao círculo, infinitude, calidez, proteção.

As formas simples associadas conduzem a figuras mais complexas, relacionandoas ao equilíbrio e ao movimento. A simetria estuda a maneira de acumular estas formas pelo princípio da repetição. Munari (1997, p. 170) classifica as regras da simetria como: IDENTIDADE consiste na sobreposição de uma forma sobre si mesma, ou então na rotação total de 360 graus sobre o seu eixo;

TRANSLAÇÃO é a repetição de uma forma ao longo de uma linha que pode ser reta ou curva; ROTAÇÃO a forma gira em torno de um eixo que pode ser interior ou exterior à forma; 
REFLEXÃO ESPECULAR é a simetria bilateral que se obtém pondo algo à frente de um espeIho e considerando o conjunto da coisa com a sua imagem;

DILATAÇÃO é uma ampliação da forma, que não sofre modificação, apenas expansão.

\section{RITMO E EQUILÍBRIO}

O equilíbrio visual é estabelecido pela distribuição dos elementos na página, o peso gráfico pode estar distribuído igualmente ou proporcionalmente no espaço. Os designers têm como instrumento os pares de contraste: grande com o pequeno e o claro com o escuro. Num projeto simétrico estável elementos iguais devem ser dispostos em pelo menos dois lados de um eixo comum, o que equivale ao equilíbrio de compensação (DONDIS, 1997).

Desenhos simétricos quando colocados lado a lado estabelecem um equilíbrio e estabilidade visual. Ao descolar um dos objetos ganha-se dinâmica e um layout de maior interesse para o leitor. Emprega-se, também, com este mesmo fim, a variação no tamanho, textura, cor e peso das formas (LUPTON; PHILLIPS, 2008).

O ritmo é um padrão constante e repetitivo, e é mais facilmente percebido em livros com narrativa sequencial forte. Os designers buscam a mudança e a variação do ritmo. No caso de um livro, esta variação se dá na escala figurativa e no valor tonal ao longo das páginas.

\section{TEXTURA}

O mundo está repleto de texturas naturais, e se pode recriar uma textura por meio de um material e instrumentos específicos. A característica da textura é a uniformidade, o olho humano a interpretá como superfície, "cada textura é formada por muitos elementos iguais ou semelhantes, dispostos a igual distância entre si sobre uma superfície de duas dimensões ou com um pouco de relevo" (MUNARI, 1997, p. 74).

A textura induz, naturalmente, ao toque, apesar de a experiência ótica sobrepujar a tátil nos livros. Alguns substratos possuem a capacidade de imitar outros materiais, o que permite brincar, no livro-objeto, com as características táteis associadas ao uso da imagem.

Uma página palpável possui duas formas de leitura: a da manipulação e a do olhar, cada uma fornece diferentes informações. Uma superfície lisa e brilhante é diferente de uma rugosa e brilhante. Quando o designer utiliza-se do recurso da textura para estabelecer uma atmosfera, ele reforça um ponto de vista ou expressa uma sensação de presença física. Este recurso pode ser potencializado quando trabalhado com seus pares de contrastes, como por exemplo, espinhosa/lisa, pegajosa/seca, rugosa/macia (LUPTON; PHILLIPS, 2008).

Se, por um lado, a textura agrega valor à imagem, pois reforça certas características, por outro, se mal empregada, pode distrair o leitor com um ruído indesejável.

\section{ESCALA}

O conceito de escala é relativo; um elemento gráfico pode parecer maior ou menor dependendo do tamanho, da localização e da cor, de forma que tudo o que o cerca influencia 

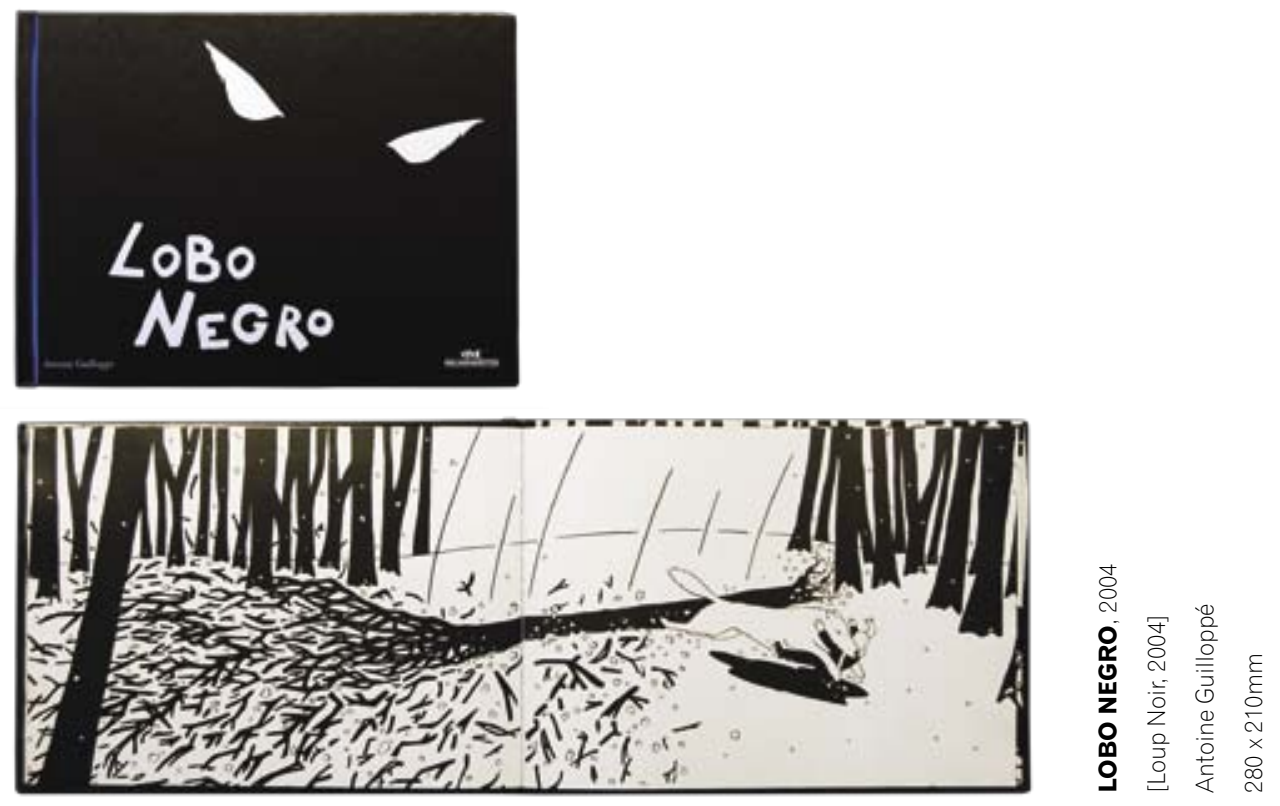

em sua percepção. Quando os elementos têm o mesmo tamanho, o projeto fica monótono. O contraste no tamanho dos elementos cria a tensão, obtendo uma sensação de movimento e profundidade (LUPTON; PHILLIPS, 2008).

Toda imagem, quando inserida num campo visual, apresenta uma referência de tamanho, pequeno ou grande, que não necessariamente corresponde ao valor real.

\footnotetext{
A medida é parte integrante da escala, mas sua importância não é crucial. Mais importante é a justaposição, o que se encontra ao lado do objeto visual, em que o cenário ele se insere; esses são os fatores mais importantes (DONDIS, 1997, p.73).
}

O tamanho e a escala do desenho também influenciam na percepção da mensagem. O formato do desenho altera a percepção do tamanho da página, aumentando ou diminuindo os lados da página (SHULEVITZ, 1997). A manipulação da escala corresponde à percepção espacial, esta oferece a ilusão de que determinado desenho é maior ou menor, por isso sua importância na estrutura da mensagem visual.

\section{FIGURA E FUNDO}

As relações de figura e fundo definem a percepção visual. Uma figura é sempre vista em relação ao que a rodeia. O equilíbrio entre figura e fundo proporciona ordem à forma e ao espaço, por meio do contraste entre forma e contra-forma, dessa forma constroem-se ícones, ilustrações, marcas, composições e padronagens que estimulam o olhar. Ao compreender o fundo, o designer tem o poder de criar e destruir as formas. (LUPTON; PHILLIPS, 2008).

Uma relação estável de figura/fundo existe quando o volume proposto destaca-se claramente do seu fundo. Guilloppé ilustra Lobo Negro com o contraste do preto da tinta 

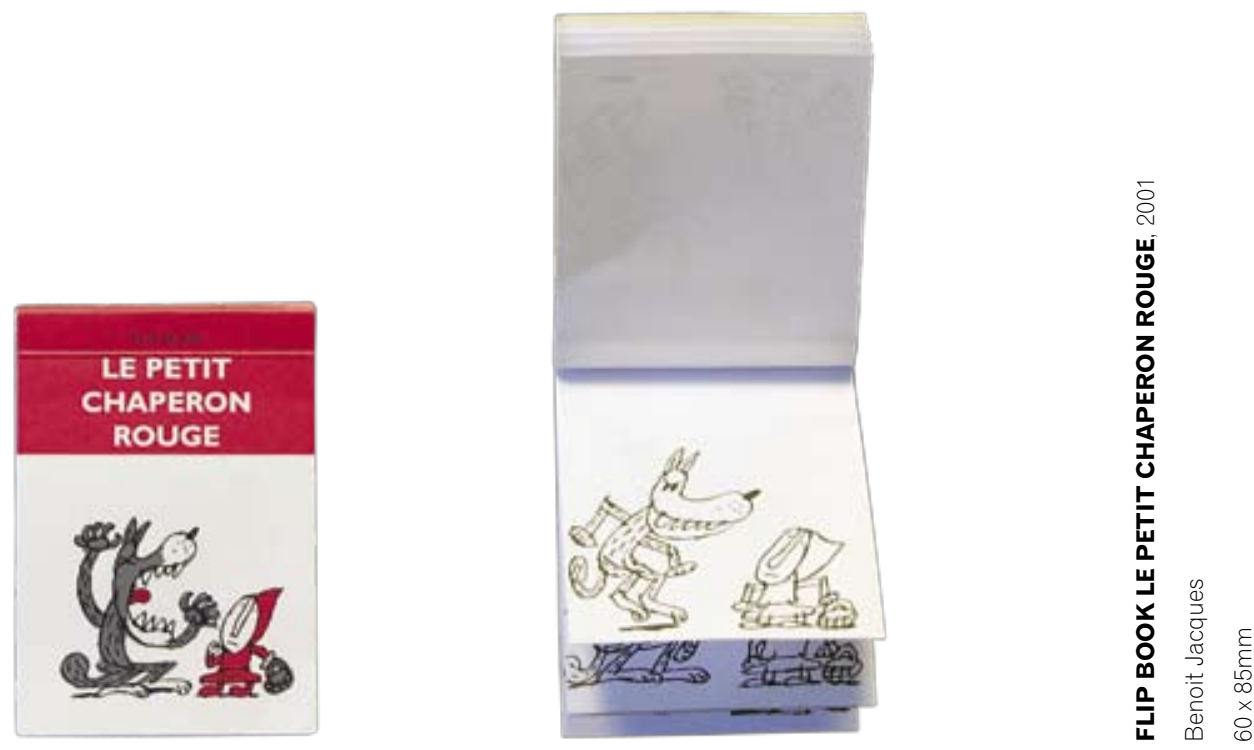

e o branco do papel, trabalhando a relação de figura e fundo. Neste livro, as massas de preenchimento criam texturas que fornecem tensão à narrativa visual.

\section{MOVIMENTO}

O movimento é um elemento visual que se encontra mais implícito do que explícito. A sugestão de movimento nas manifestações visuais estáticas é difícil de se obter sem que se distorça a realidade.

A percepção de movimento é alcançada a partir de quadros com ligeiras modificações. Estes, quando vistos pelo leitor no intervalo de tempo apropriado, fundem-se de tal forma que o movimento parece real. A sequência narrativa em movimento é o princípio da animação. Esta se fundamenta na criação da ilusão ótica de movimento, trabalhando com fragmentos retidos no cérebro por uma fração de segundos e sua sucessão rápida, a sequência retida fornece a percepção do movimento (LUPTON; PHILLIPS, 2008).

Le petit Chaperon Rouge é um exemplo da narrativa em movimento. Esta é uma versão divertida da história de Chapeuzinho Vermelho, em que a protagonista assusta o lobo com suas caretas. O flip permite ao leitor estabelecer a velocidade da narrativa e o ponto de ínicio, através de sua manipulação.

A menor unidade de movimento é o quadro. Este se move obedecendo a uma sequência linear de páginas e desenhos sucessivos, ou sobrepostos. A transição de um quadro a outro se dá de duas formas: alterando suas características físicas, como, variações de escala, cor, forma ou transparência, ou alterando sua posição relativa, com mudanças de posição, rotação e profundidade (LUPTON; PHILLIPS, 2008). 


\section{PRODUÇÃO GRÁFICA}

A produção gráfica é a etapa seguinte ao projeto gráfico, e segue a seguinte sequência de trabalho: a pré-impressão, a impressão e o acabamento. Cabe à produção gráfica a escolha do suporte, o material no qual o livro será impresso.

Villas-Boas (2007, p.16-17) descreve as etapas da produção gráfica:

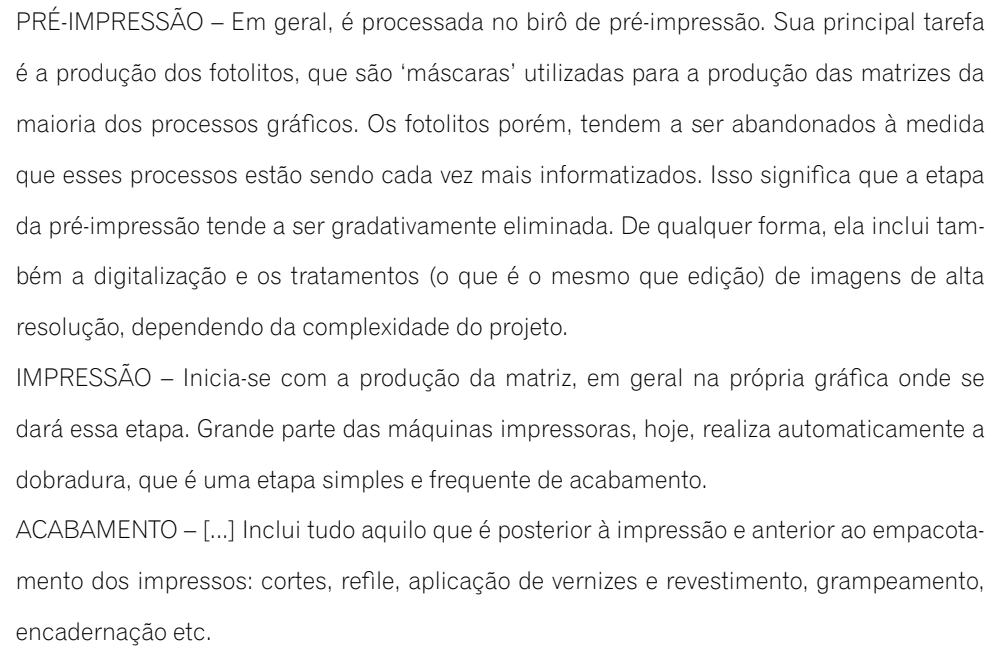

Conhecer todos os processos de produção evita problemas no impresso final e possibilita ampliar a exploração gráfica frente às tecnologias presentes na indústria gráfica. A escolha certa do suporte, no processo de impressão e nos acabamentos, melhora a qualidade do produto, bem como reduz os custos de produção.

No caso dos livros-objeto, grande parte da exploração lúdica é obtida por meio da produção gráfica. Entender as etapas do trabalho significa viabilizar o projeto. O suporte deve ser compatível com o processo de impressão, assim como os acabamentos que não devem apenas agregar valor estético, mas potencializar o lúdico.

\section{PRÉ-|| M PRESSÃO}

O advento de novas tecnologias digitais impõe uma atualização a este setor. Os processos computadorizados reduzem as etapas de trabalho. A disseminação desses processos exige um conhecimento técnico cada vez mais refinado por parte dos profissionais de editoração (ARAÚJO, 2008).

O processo CTP, Computer To Plate, um dos principais avanços na pré-impressão, oferece possibilidades de resoluções mais altas, ao empregar retículas mais finas e delicadas do que as empregadas nos métodos de impressão tradicionais. Utiliza um método de posicionamento, em que coloca cada ponto no local onde deveria estar, o que gera linhas suaves com maior resolução e com bordas menos serrilhadas (AMBROSE; HARRIS, 2009). 

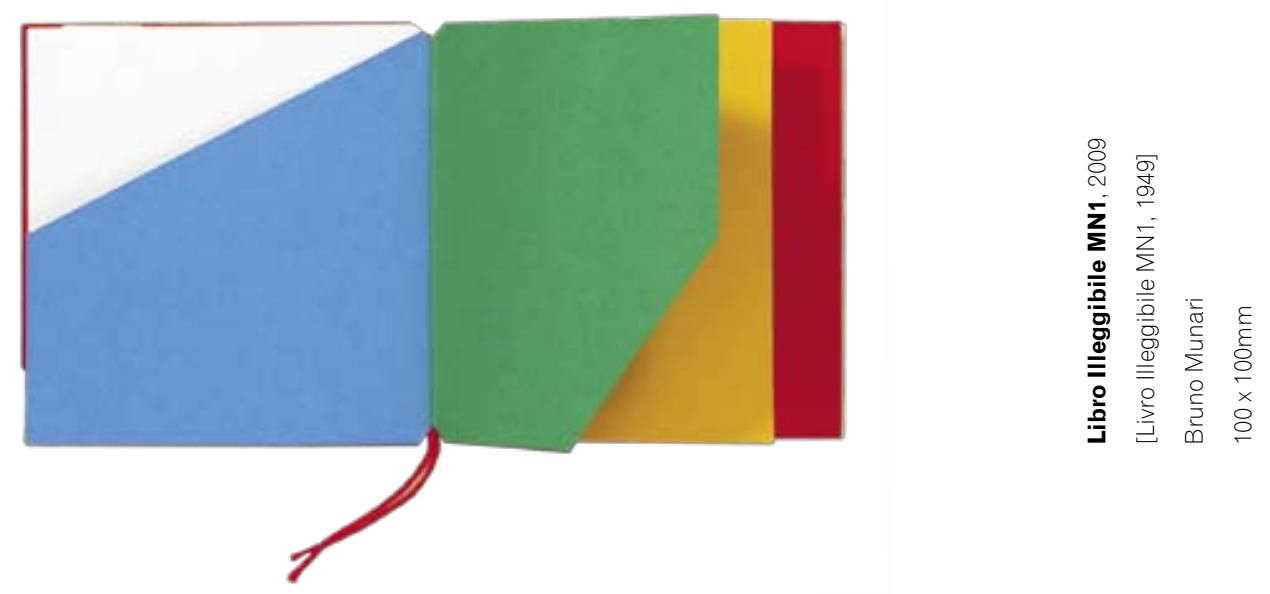

Os arquivos digitais otimizam a produção do livro. A tecnologia na pré-impressão e o conhecimento do produtor gráfico permitem antever os problemas de impressão, produzindo livros cada vez mais perfeitos e baratos. Os procedimentos de pré-impressão, a gravação das matrizes, a escolha do tipo de retícula e a imposição das páginas de livro não são executados pelo designer, mas podem ser acompanhados em gráfica.

O planejamento da posição das páginas no formato da folha da gráfica deve ser realizada ainda em projeto. Esta organização, chamada imposição da página, distribui o máximo de páginas por folha impressa levando em conta a montagem dos cadernos, bem como a sequência de páginas, para que coincidam frente e verso.

Entender a imposição permite ao designer explorar a inserção de diferentes papéis intercalados em cadernos. A disposição das páginas pode ser também utilizada para baratear o custo de uma publicação, quando as páginas de texto são impressas em uma única cor e as páginas coloridas são, posteriormente, inseridas entre os cadernos.

Libro illeggibile MN1 é composto de folhas coloridas: vermelha, amarela, verde, azul, branca, rosa e laranja. Dobradas ao meio de forma a montar um caderno e com recortes localizados estrategicamente nas laterais que permitem a sobreposição das cores, compondo assim o discurso visual. As páginas são unidas sem costura, apenas com uma linha de lã vermelha no meio do caderno. Este livro-objeto faz parte de um conjunto de experiências visuais de Bruno Munari, que partem da premissa de narrar sem texto.

\section{PROCESSO DE IIMPRESSÃO}

Impressão refere-se às diferentes técnicas para aplicar tinta sobre um suporte, entre elas: offset, serigrafia, gravura (em metal), tipografia, xilogravura, tampografia, rotogravura, flexografia, impressão a jato de tinta, impressão a laser, entre outras. Cada método tem variáveis próprias, como a velocidade de impressão, a qualidade do impresso, a variedade disponível de cores e o custo de produção por tiragem (AMBROSE; HARRIS, 2009). 
Existem dois parâmetros que diferenciam o processo de impressão: o tipo de matriz utilizada e o método de transferência de dados. Cada matriz tem um custo de produção, por isso o número de cópias e a qualidade da impressão são os principais fatores que determinam a escolha de cada processo.

Há quatro tipos de matrizes: a tinta permanece sobre a superfície de impressão, transferindo diretamente em relevo a imagem (letra e desenho) para o papel, como na tipografia e no digital; a tinta permanece abaixo da superfície de impressão, e o papel, pressionado por um cilindro, retira a tinta das cavidades dessa matriz para receber a imagem, como na rotogravura; a tinta, sobre uma superfície plana, passa para um cilindro de borracha intermediário, transferindo indiretamente a imagem, como no offset; a tinta seca, sobre uma superfície plana, transfere-se diretamente para o papel por ação eletrostática, como na xerografia; e a tinta líquida, contida em cartuchos controlados eletronicamente, é borrifada diretamente sobre o papel ou outro suporte, como a impressão jato de tinta (ARAÚJO, 2008).
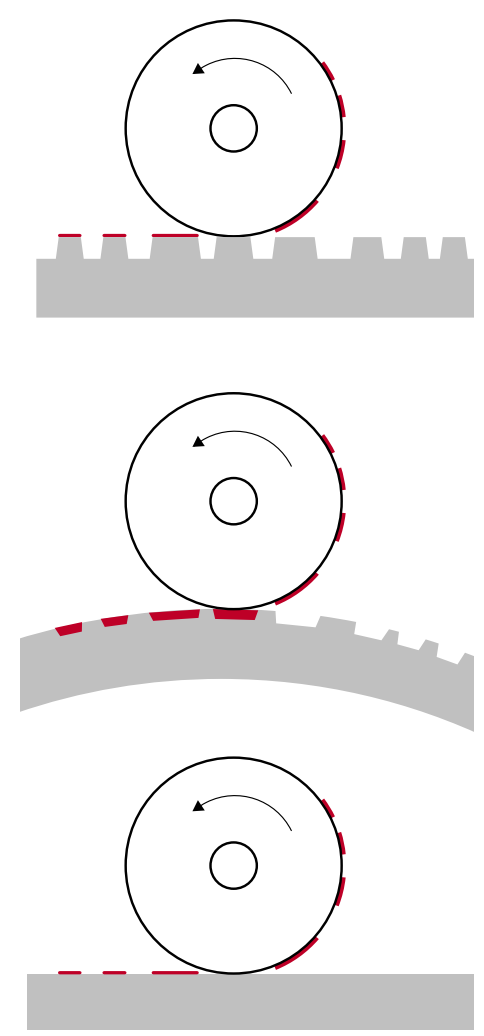

RELEVOGRÁFICA

\section{ENCAVOGRÁFICA}

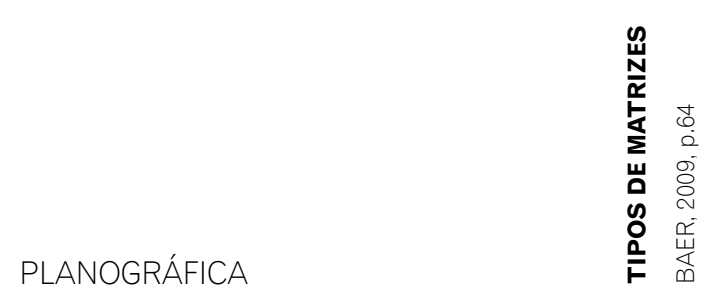

Atualmente, o processo mais utilizado na impressão de livros é o offset, devido à boa qualidade de reprodução e o custo intermediário na produção das matrizes. Em segundo lugar, vem a rotogravura, com melhor qualidade na impressão, porém de matrizes mais caras, destinando-se, por isso, mais a livros de luxo ou livros didáticos de alta tiragem (acima de dez mil cópias). 

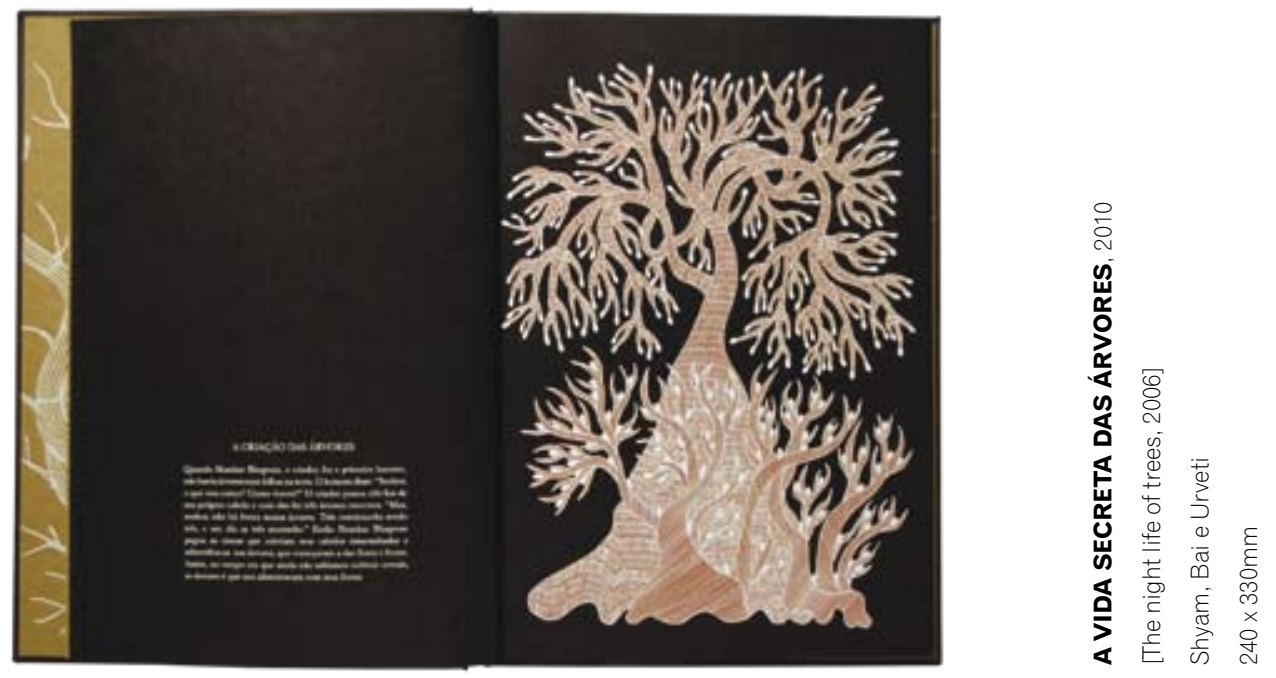

No caso do livro-objeto, o offset é o processo predominante, mas, pela natureza experimental do objeto, encontram-se alguns impressos em serigrafia e litografia. A serigrafia é ainda pouco utilizada, contudo, é um processo que imprime sobre qualquer suporte, possibilitando a exploração lúdica, assim como o uso de tinta viscosa permite adicionar qualidade tátil ao impresso.

O grupo indiano Shyam, Bai e Urveti imprime A vida secreta das árvores, utilizando a serigrafia sobre um papel texturizado preto. Aplica-se duas cores para a impressão das ilustrações e o branco para o texto.

\section{OFFSET}

O processo de impressão em offset está baseado no princípio da litografia, repulsão recíproca entre uma substância graxa e água sobre determinado suporte. É considerado o processo ideal para médias tiragens.

O offset é o principal processo desde a segunda metade do século XX. Um processo que aceita todos os tipos de papel e alguns plásticos (VILLAS-BOAS, 2008). As impressoras offset são dotadas de diversos cilindros e rolos. Os rolos entintadores constituem o que é chamado de trem de tintagem, transferindo a tinta do tinteiro para a chapa, que é fixada envolvendo o cilindro da chapa. Um segundo cilindro, encoberto por uma manta de borracha, a blanqueta, transfere a tinta da chapa para o papel transportado pelo terceiro cilindro, o de contrapressão (HASLAM, 2007).

Antes de ser entintada, a chapa offset deve ser molhada, para que as áreas de contragrafismo rejeitem a tinta. Há necessidade de regular a impressora para que a quantidade de tinta e de água seja adequada ao funcionamento. A água é aplicada na chapa por uma série de rolos emborrachados, a partir de um reservatório. Se a água for pouca, a tinta invadirá a área de contragrafismo, por outro lado, se houver excesso, a chapa ficará excessivamente molhada, e, consequentemente, o papel absorverá esta umidade e se expandirá. 


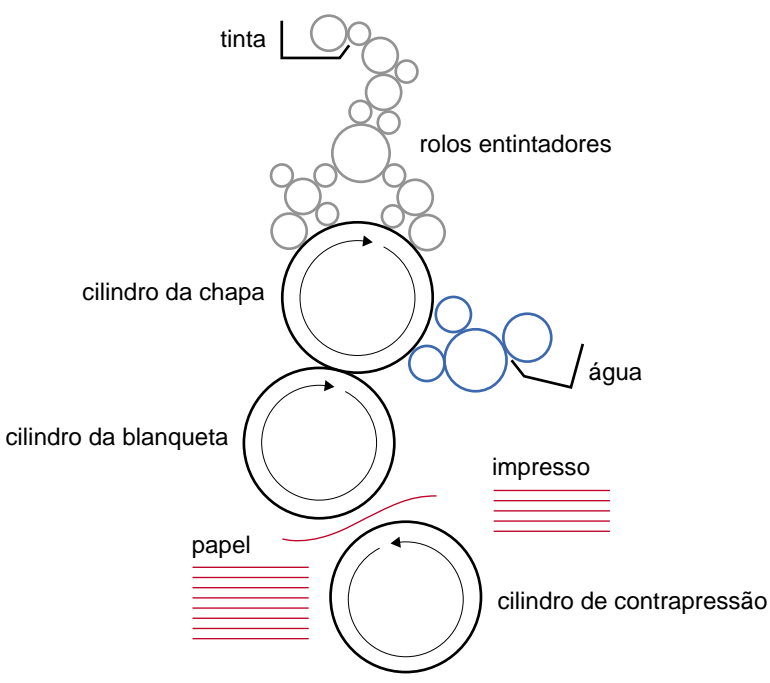

A tinta é estocada num reservatório localizado no início dos rolos entintadores. O fluxo de tinta pode ser controlado e ajustado durante a impressão, o fluxo contínuo determina uma boa impressão. A tinta é transferida do tinteiro para os rolos emborrachados, passando de um rolo para o outro, criando um filme uniforme de tinta na superfície dos rolos (HASLAM, 2007).

A impressão offset possui um mecanismo frágil e instável: são necessários reajustes frequentes durante a impressão para manter níveis adequados de tinta e umidade, tanto para evitar falhas e borrões quanto para manter a maior uniformidade possível nos tons das cores ao longo da tiragem (VILLAS-BOAS, 2008).

A qualidade na impressão é influenciada pela gravação das chapas. Se estas não forem bem gravadas, os problemas aparecerão na impressão. O excesso de exposição de luz na gravação resultará na impressão de imagens borradas. Se o tempo for reduzido, a imagem impressa perderá resolução.

Existem dois tipos de alimentação das impressoras: por folhas soltas, chamada de plana, e por rolo, chamada de rotativa. As grandes impressoras planas podem imprimir até quinze mil folhas por hora, enquanto as rotativas chegam a imprimir oitenta mil cadernos por hora. Os livros infantis, em sua maioria, são impressos nas planas (HASLAM, 2007).

\section{SERIGRAFIA}

A serigrafia é um processo permeográfico, o que utiliza uma tela, de poliéster ou de náilon, como matriz. A trama do tecido e a forma da gravação da imagem influenciam no resultado impresso. Atualmente, as telas são feitas de fios sintéticos, que variam de bitola, malha e número de fios por polegada. Se a bitola for fina e o número de fios for alto, o detalhe será realçado na reprodução dos meios-tons (HASLAM, 2007).

Existem dois tipos de gravação da tela: uma película vermelha cortada manualmente ou o processo por meio de fotolito. No caso da película, esta é colada na tela com 
uma emulsão, um processo rápido, porém que resulta numa matriz mais frágil. Quanto à gravação de fotolito, a imagem é transferida para a tela por meio de um filme fotossensível ou cobrindo-se a tela com uma emulsão fotossensível. A tela é coberta com um negativo fotográfico e os dois são colocados em uma prensa de contato e expostos à luz ultravioleta.

A mesa de impressão serigráfica pode ser constituída de uma cama de madeira perfurada acoplada a um sistema a vácuo para prender a folha. Acima da cama existe um quadro articulado com dobradiça, em que a tela é presa. Esse quadro é contrabalanceado de modo a se manter levantado enquanto o impressor margeia a folha. $\mathrm{O}$ impressor deposita a tinta sobre a tela em uma das bordas da área mascarada. O rodo é posicionado antes da tinta e a puxa ao longo de todo o comprimento da tela, pressionando-a firmemente sobre o papel, força a tinta a passar através das malhas abertas da tela. O papel é removido e colocado para secar numa esteira (HASLAM, 2007).
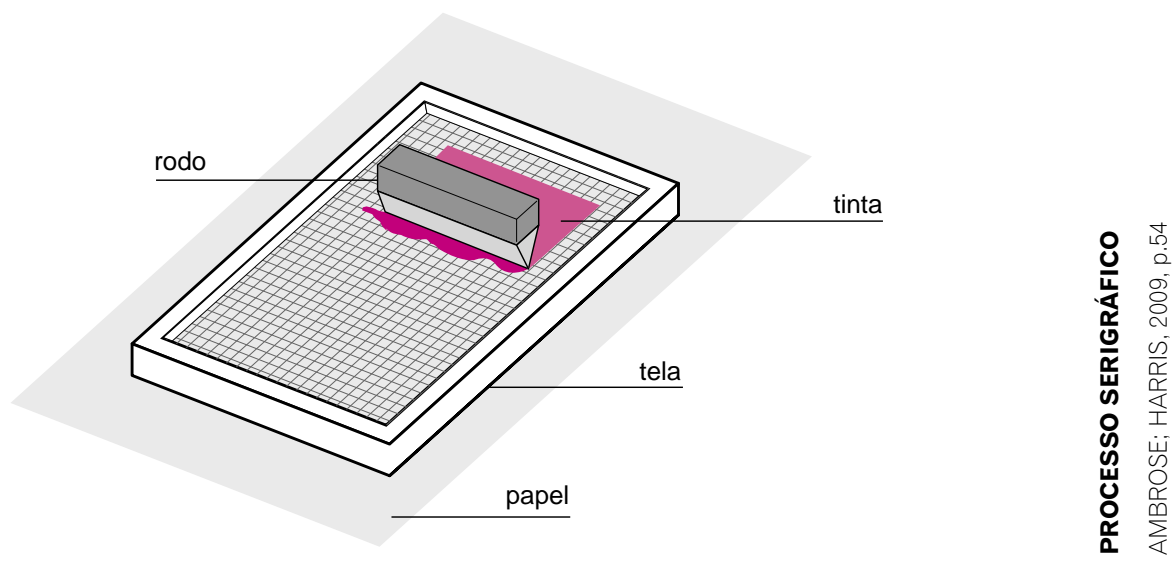

Um processo simples e manual de impressão, a um custo baixo, ideal para impressão de baixas e médias tiragens, por ser um processo lento em que cada cor deve ser aplicada separadamente (AMBROSE; HARRIS, 2009). Por outro lado, a serigrafia tem a vantagem de ser o único processo de impressão a utilizar a tinta branca, além de poder sobrepor tintas opacas e translúcidas. A qualidade desta tinta é muito maior que a dos outros processos, sua saturação e vivacidade são importantes instrumentos de design (VILLAS-BOAS, 2008).

\section{SUPORTE}

O suporte é o material que recebe a impressão do texto ou da imagem, variando desde uma folha de papel padrão aos mais variados substratos como: plástico, tecido, madeira e chapa metálica. A evolução do parque gráfico possibilita o uso de novos materiais a cada dia, inovando em produtos mais sustentáveis, baratos e duráveis.

Atualmente, existe uma grande variedade de suportes na confecção de livros infantis, tais como papéis especiais, encartes, recortes, acolchoados, infláveis, entre outros. Além do enriquecimento visual, isto incentiva o espírito criativo das crianças (LINS, 2003). 
A escolha do suporte mais adequado à necessidade de impressão é feita no início do projeto gráfico, em que se leva em conta a finalidade do trabalho e o custo unitário de cada livro. Há suportes de muitas cores, texturas e gramaturas diferentes, características que influenciam no impacto do produto final, agregando um diferencial de qualidade ao livro (AMBROSE; HARRIS, 2009).

Quando se analisa o livro infantil tradicional, observa-se o predomínio do papel como suporte, sendo o cartão o segundo material mais usado. O livro-objeto também apresenta este padrão, mas o diferencial entre eles está no final do processo de produção, no acabamento. Diante deste panorama, aborda-se a seguir o papel com suas características físicas e químicas, propriedades que devem ser levadas em conta no design do livro.

\section{O PAPEL}

O papel é constituído de uma estrutura porosa, trama de fibras entrelaçadas, quase sempre de natureza vegetal, e de espessura regular. A produção origina-se da suspensão aquosa de uma matéria fibrosa e posterior escoamento da água através de uma tela em sucessivas secagens (BAER, 2009).

A composição da pasta celulósica, composta de fibras vegetais e farpas de madeira, associada ao mecanismo de separação e posterior revestimento, determina as características do papel produzido, que afetam diretamente a percepção do leitor quando usadas na reprodução de imagens.

\section{CARACTERÍSTICAS DO PAPEL}

\section{sentido da fibra}

O sentido da fibra determina a direção em que o papel dobra e rasga com maior facilidade. A melhor escolha para o livro é o papel cuja fibra corre no sentido longitudinal da folha (paralela à lombada), o que permite a melhor dinâmica para o movimento de folhear, sem qualquer enrugamento (ARAÚJO, 2008). A atenção ao sentido da fibra é um dado importante quando se pensa num projeto com dobras. Quanto maior a gramatura do papel ou a espessura, maior a necessidade de que as dobras coincidam com a direção da fibra. As dobras no sentido contra-fibra tornam-se difíceis, gerando dobras irregulares ou quebradiças. Os vincos amenizam os efeitos das fibras nas dobras (VILLAS-BOAS, 2008).

\section{cor}

A cor do papel, determinada pela adição de pigmentos e alvejantes, geralmente no estágio de preparação da pasta, afeta o resultado impresso da imagem e do texto. Na impressão não se consegue pontos mais luminosos que a cor do papel. Papéis com bom grau de alvura são recomendados para reprodução em policromia, enquanto papéis levemente amarelados e com alto grau de opacidade são indicados para livros de leitura, evitando o cansaço visual e a transparência no texto (ARAÚJO, 2008). 


\section{opacidade}

A opacidade é a medida da quantidade de luz que passa através da folha de papel. Isso é determinado pela espessura, pela densidade das fibras e pelo tipo de acabamento superficial. A opacidade é importante, pois define o grau de transparência das páginas (HASLAM, 2007). A transparência pode ser usada a favor de um projeto, ou pode prejudicar sua legibilidade e estética. Se o papel for muito transparente, o leitor terá sua atenção constantemente desviada pelo texto impresso no verso (ARAÚJO, 2008).

\section{brilho}

O papel com brilho cria uma camada homogênea de destaque na página impressa, o que dificulta a fixação de determinados detalhes da ilustração (NOLDELMAN, 1988).

\section{gramatura}

No Brasil, o peso do papel é expresso em gramas por metro quadrado $\left(\mathrm{g} / \mathrm{m}^{2}\right)$. O sistema métrico considera sempre o peso por uma folha A0 (HASLAM, 2007). Nem sempre o peso do papel indica a espessura deste, a matéria-prima determina a variação. A gramatura está ligada diretamente ao custo do livro, principalmente na logística de envio postal (ARAÚJO, 2008). Entretanto, deve-se ponderar na escolha da gramatura o fator de transparência, o que compromete o resultado esperado. A disponibilidade de gramaturas varia por fabricante e tipo de papel. O offset e o couché são os papéis que mais oferecem variações. No caso do offset, a gramatura vai de $44 \mathrm{~g} / \mathrm{m}^{2}$ a $320 \mathrm{~g} / \mathrm{m}^{2}$. Apesar das opções, a maioria dos papéis de gramatura próximas são comercializados em bobina, atendendo ao mercado de alta tiragem (VILLAS-BOAS, 2008).

\section{espessura}

A espessura ou corpo do papel determina o volume do livro. Quanto mais áspera a folha maior será a espessura, enquanto fibras mais unidas terão densidades maiores (ARAÚJO, 2008). A densidade do papel varia de acordo com o material empregado na sua produção. (HASLAN, 2007).

\section{textura}

A textura diz respeito ao aspecto da superfície do papel e ao seu grau de rigidez. Cada livro solicita uma textura diferente, sendo a criatividade determinante em sua escolha (ARAÚJO, 2008). O papel texturizado convida o leitor ao toque, estabelecendo uma atmosfera de intimidade e de envolvimento (NOLDEMAN, 1988). Apesar dos papéis com textura singularizarem o produto final, eles não são indicados para policromias com grande exigência de nitidez nos detalhes, e devem ser evitados no uso de corpo tipográfico abaixo de oito pontos. Na serigrafia, na xerografia e no digital o uso de papel texturizado compromete a leitura (VILLAS-BOAS, 2008). O acabamento superficial da folha de papel determina sua capacidade de ancoragem da tinta e sua adequação a diferentes tipos de impressão. A superfície do papel é determinada na produção: quanto mais calandrado o papel, maior será sua superfície lisa (HASLAM, 2007). 


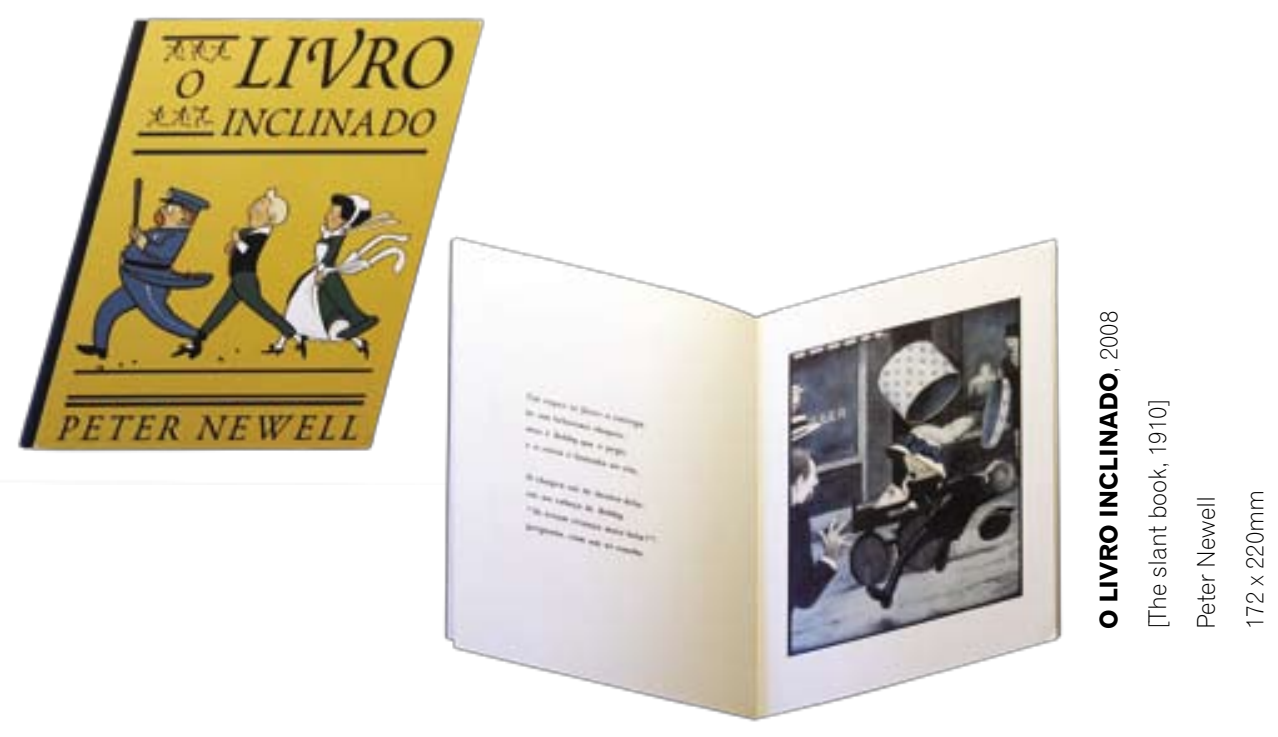

\section{ACABAMENTO}

O acabamento é o último estágio do processo gráfico, momento em que o impresso ganha um toque final. Algumas técnicas, como recortes especiais, impressão em relevo, aplicação de verniz, hot stamping, são capazes de transformar uma peça comum em um objeto interessante.

Os processos de acabamento podem adicionar elementos decorativos, brilho, textura, cheiro, e também podem agregar funcionalidade ao livro-objeto. O corte especial, por exemplo, altera o produto físico, mudando sua forma e a percepção do leitor.

Embora o acabamento seja executado no fim do processo de produção, as técnicas de acabamento devem ser planejadas como parte integrante do projeto gráfico (AMBROSE; HARRIS, 2009).

O projeto do livro-objeto deve levar em conta o orçamento para a sua produção. $O$ uso de determinados acabamentos encarece o livro, sem agregar, por vezes, nenhum valor údico. Deve-se evitar o uso do acabamento de forma arbitrária, explorando os recursos disponíveis no parque gráfico, sem se esquecer da viabilidade econômica.

Um projeto que não leve em consideração as realidades circundantes - tecnológicas, sociais, culturais, econômicas, ecológicas - não é um projeto viável para a sociedade. É apenas um exercício de diletantismo, às vezes até virtuoso e de talento, mas vazio (FERLAUTO, 2001, p. 34).

REFILE

O refile corresponde ao corte do material impresso, de forma a obter o tamanho desejado, bem como manter o alinhamento lateral dos cadernos. O primeiro corte, antes de se dobrar a folha, recebe o nome de corte linear. Usando uma guilhotina elétrica de alta precisão, elimina-se as margens e as marcas de impressão. Essa operação pode ajustar o tamanho final ou apenas separar as unidades impressas (BAER, 2009). 
No caso do livro, o refile final é realizado na guilhotina trilateral, capaz de refilar os três lados simultaneamente. Desta forma, obtém-se uma tiragem de formato homogêneo (VILLAS-BOAS, 2008). O refile final pode receber um acabamento diferenciado, como chanfros para arredondar os cantos do livro, usualmente projetados para que o pequeno leitor consiga segurar o livro-objeto sem se machucar.

O livro inclinado apresenta um refile especial, inclinado, para que o leitor tenha uma estranheza visual ao abrir o livro. As ilustrações e o texto, dispostos no mesmo ângulo de inclinação, acentuam a brincadeira do carrinho de bebê descendo uma ladeira inclinada. Este livro não teria a mesma leitura se seguisse o formato tradicional.

\section{DOBRADURA}

As dobras no livro permitem a formação dos cadernos, a quantidade de dobras é determinada pela gramatura da folha. Para manter a qualidade nos livros, Baer (2009) recomenda montar cadernos no máximo de 16 páginas, evitando que o papel amasse, além de facilitar o registro na hora de realizar a dobradura e manter o caderno mais fechado.

Os métodos de dobra produzem diferentes efeitos criativos e oferecem diversos usos para o impresso. Pode-se obter efeitos como páginas desdobráveis, dobra francesa, dobra-sanfona e dobra enrolada (AMBROSE; HARRIS, 2009).

A página desdobrável consiste numa folha de papel dobrada que é encadernada junto com a publicação, a fim de produzir um espaço a mais para uma determinada imagem ou elemento visual. Este tipo de página esconde uma surpresa ao leitor, este mecanismo comanda o jogo de adivinhação.

A dobra francesa é uma folha impressa e dobrada vertical e horizontalmente para formar um caderno de quatro páginas não-refiladas. Quando a dobra francesa é utilizada no livro, aumenta o volume da publicação. O caderno é costurado na lombada para que as bordas frontal e superior permaneçam dobradas e não-refiladas.

A dobra-sanfona consiste em duas ou mais dobras paralelas, permitindo que muitas páginas sejam dobradas em uma publicação de tamanho menor. Esse método de dobras pode ser utilizado no livro-objeto, como em Le petit chaperon rouge, no qual o leitor
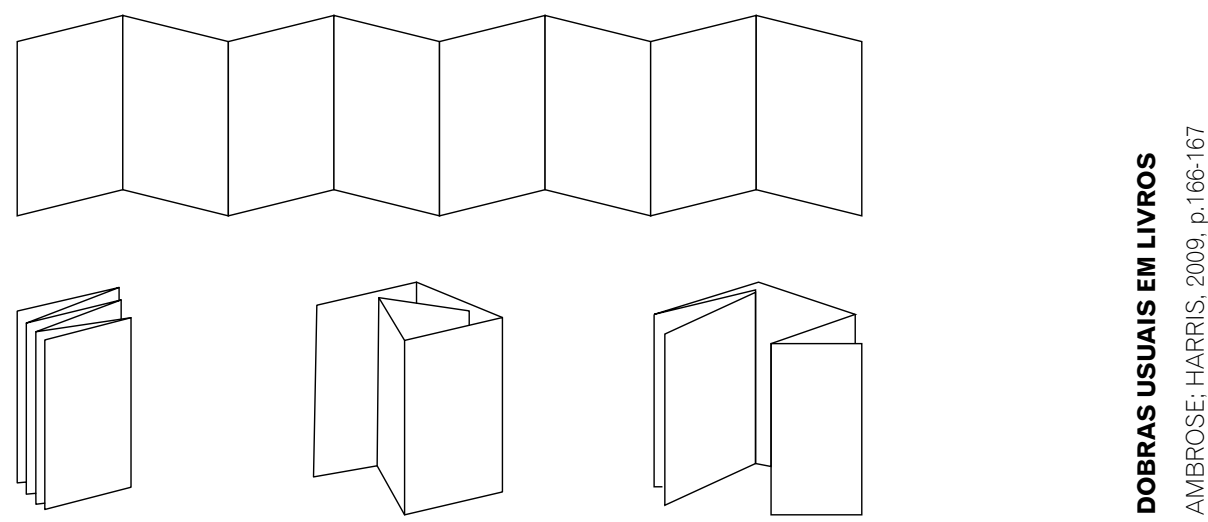

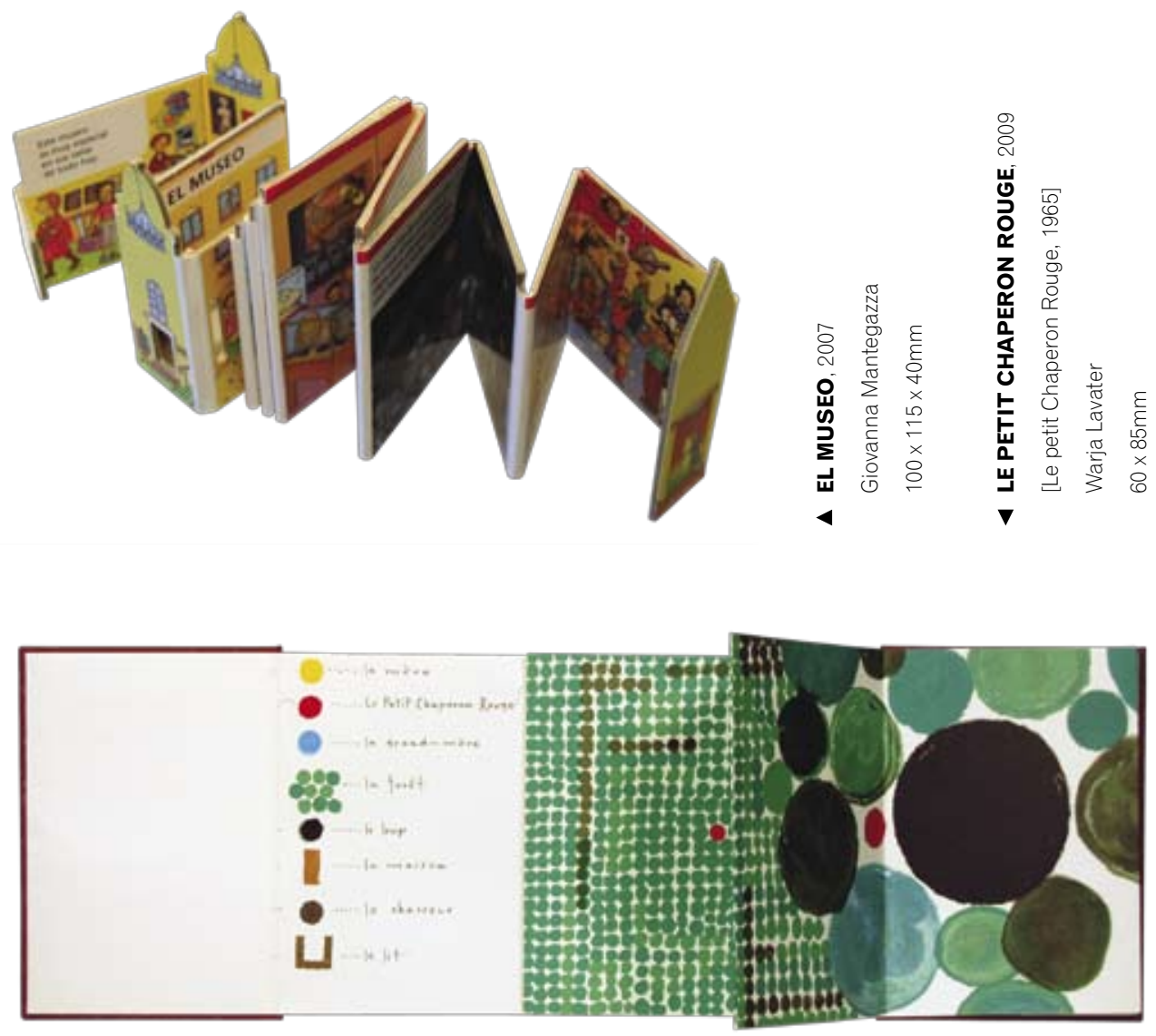

se depara com duas possibilidades no ritmo de leitura: a forma tradicional do livro encadernado ou a forma linear em rolo. Este livro-objeto é composto por uma única sanfona dobrada e montada sob duas lâminas de capas duras revestidas por tecido.

Le petit chaperon rouge é uma releitura do conto de fadas clássico, Chapeuzinho Vermelho, por meio de uma narrativa visual. Ao abrir o livro, o leitor encontrará uma legenda dos pontos coloridos, com todas as informações necessárias para que se possa entender a narrativa visual que se seguirá. No desdobrar das páginas, diversos pontos coloridos preenchem o espaço, dando movimento à narrativa.

A dobra enrolada é composta por uma série de dobras paralelas, umas sobre as outras. Quando o leitor abre o livro enrolado, o conteúdo é gradualmente revelado, página por página, numa lenta descoberta.

Em El museo, as dobras revelam uma das opções de percurso que o leitor pode vivenciar ao visitar um museu. O ritmo de leitura é ditado pelo desdobrar das páginas, resultando numa longa tira com as páginas-duplas dispostas lado a lado. Trata-se da impressão de uma única folha que recebe, posteriormente, a laminação. Duas lâminas impressas são empastadas em cartão já recortado nos moldes de museu. Este acabamento permite a estrutura rígida do livro que, ao mesmo tempo é uma sanfona flexível. 


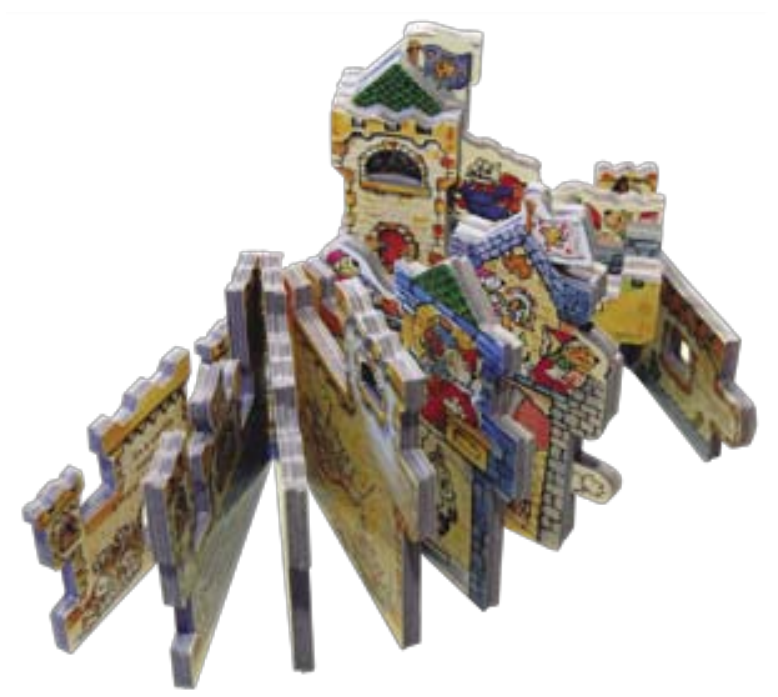

\section{CORTE ESPECIAL}

O corte especial é um processo que permite cortar uma parte específica de uma página. A lâmina de aço com corte é moldada conforme o projeto gráfico (AMBROSE; HARRIS, 2009). A lâmina moldada, conhecida como faca especial, é presa numa base de madeira, que quando pressionada sobre o papel realiza o corte. A indústria gráfica utiliza este recurso na produção de embalagens e impressos decorativos.

Nos livros-objeto, esse recurso possibilita a inclusão de janelas, abas, pop-up, chanfros e contornos especiais nas bordas das páginas. Em The enchanted castle, cada página possui um corte especial, resultando num volume inusitado, que simula um castelo. Este livro é uma releitura do clássico conto de fadas A bela adormecida, com a substituição dos protagonistas humanos por animais. O projeto usa diferentes facas especiais no contorno das páginas e na criação de janelas. Os volumes e formas inusitadas permitem ao leitor diferentes perspectivas ao folhear as páginas. Apesar do formato lúdico, o enredo está disposto numa forma linear de leitura.

Rodando, rodando, rodando... centra sua narrativa visual na sequência de facas especiais redondas, simulação de rodas de diferentes meios de transporte. Partindo dos dois buracos da capa, a cada página, os buracos diminuem progressivamente até a última página do livro. Os textos presentes neste livro-objeto, escrito na versão brasileira por Carr, trazem brincadeiras no formato de adivinhas relacionando o nome do transporte ilustrado (trens, betoneira, jipe, carro, bonde e bicicleta) ao tamanho de suas rodas.

POP-UP

O pop-up pode ser considerado uma categoria de livro-objeto, um dos mais difundidos entre o público infantil. Por meio de dobras e facas especiais no papel aproveita-se a energia cinética do movimento de virar a folha para criar modelos tridimensionais que saltam das páginas. 

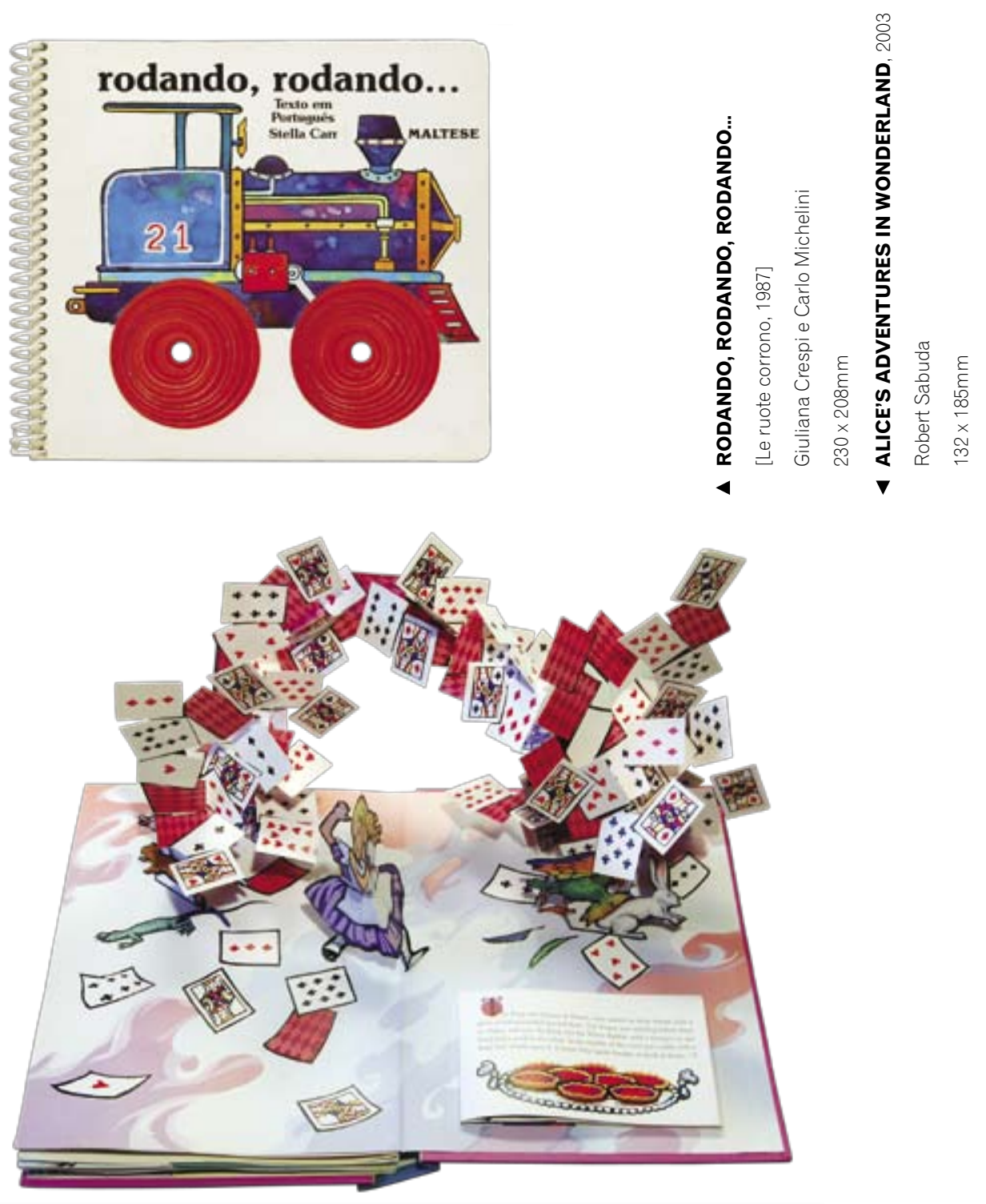

Os engenheiros de papel, frequentemente, tornam-se autores visuais, desenvolvendo o conceito do livro no planejamento do pop-up de papel. O desenvolvimento do pop-up é um processo demorado, na base da tentativa e erro, incluindo o corte e a dobragem de muitos protótipos até se obter o resultado desejado (HASLAM, 2007). O engenheiro do papel deve ponderar os pop-up complexos com a realidade da produção. Quanto maior o número de componentes e pontos de cola, maior a perda de tempo e o custo do acabamento de cada página.

Alice's adventures in wonderland é uma adaptação da obra de Lewis Carroll, Alice no país das maravilhas, transformado-a em narrativa tridimensional. O leitor fica surpreso com as imagens que saltam das páginas, o movimento de virar a folha fornece a força para o desdobrar das ilustrações. Cada dupla contém uma dobradura principal, e nas laterais o leitor encontra folhas dobradas em sanfona, onde estão os textos do livro e outras pequenas dobraduras, motivando o leitor a explorar todas as páginas e cantos deste livro-objeto. 

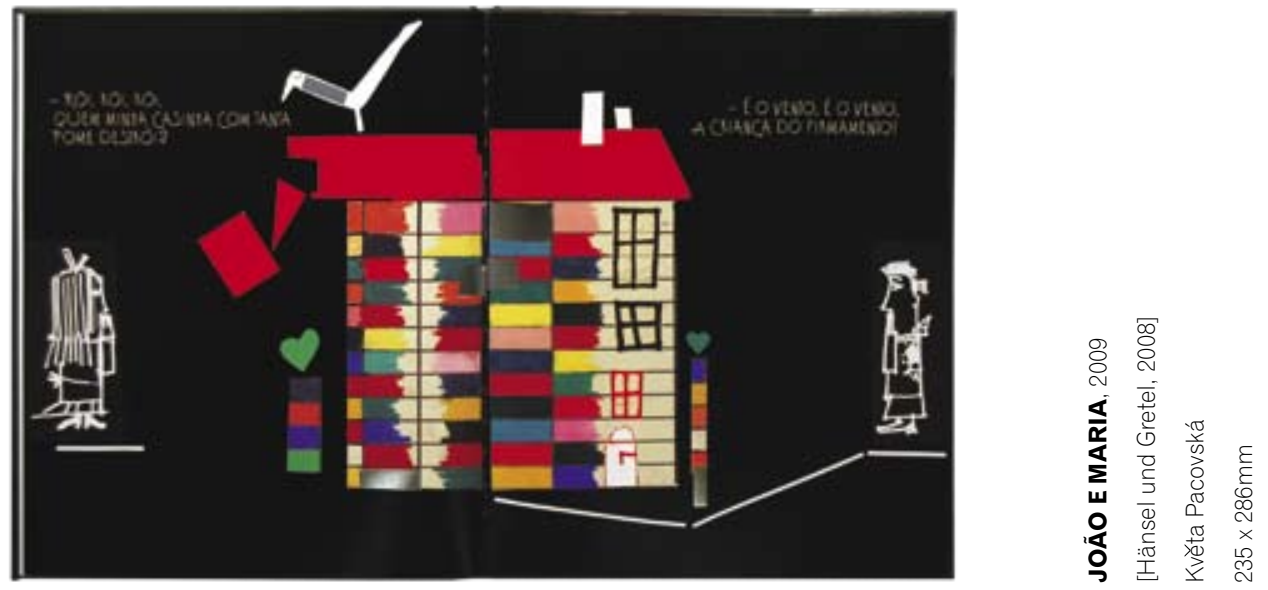

\section{RELEVO SECO, ALTO-RELEVO E BAIXO-RELEVO}

Os termos relevo seco, alto-relevo e baixo-relevo designam a impressão de um suporte sem tinta, o que resulta em uma superfície tridimensional, elevada, decorativa ou texturizada, que destaca determinados elementos de um projeto. Normalmente, o suporte utilizado para o alto-relevo e baixo-relevo é o papel de maior gramatura (AMBROSE; HARRIS, 2009).

A imagem impressa é obtida por meio da pressão da matriz e do contra-molde. A diferença do processo de impressão do alto-relevo e do baixo-relevo consiste na posição da matriz. O relevo fornece ao livro uma leitura tátil, podendo ser usado para sensibilizar o leitor.

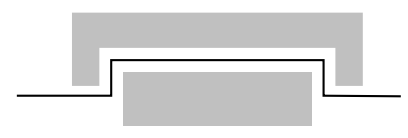

ALTO-RELEVO
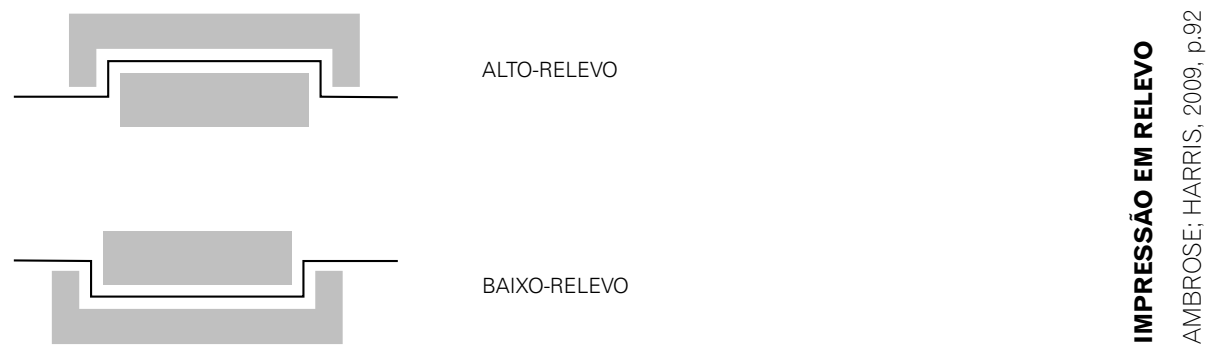

BAIXO-RELEVO

HOT STAMPING

Hot stamping, também conhecida como gravação a quente, é um processo em que um laminado colorido transfere-se para o papel por meio de um molde aquecido. O laminado é um filme de poliéster que contém um pigmento seco, que fornece um acabamento de aspecto metálico. No livro João e Maria, o hot stamping foi utilizado para conferir destaques à ilustração, os elementos prateados criam pontos luminosos quando o leitor manipula o livroobjeto. Aplicados em formas de tiras retangulares, estes elementos obedecem à linguagem. 


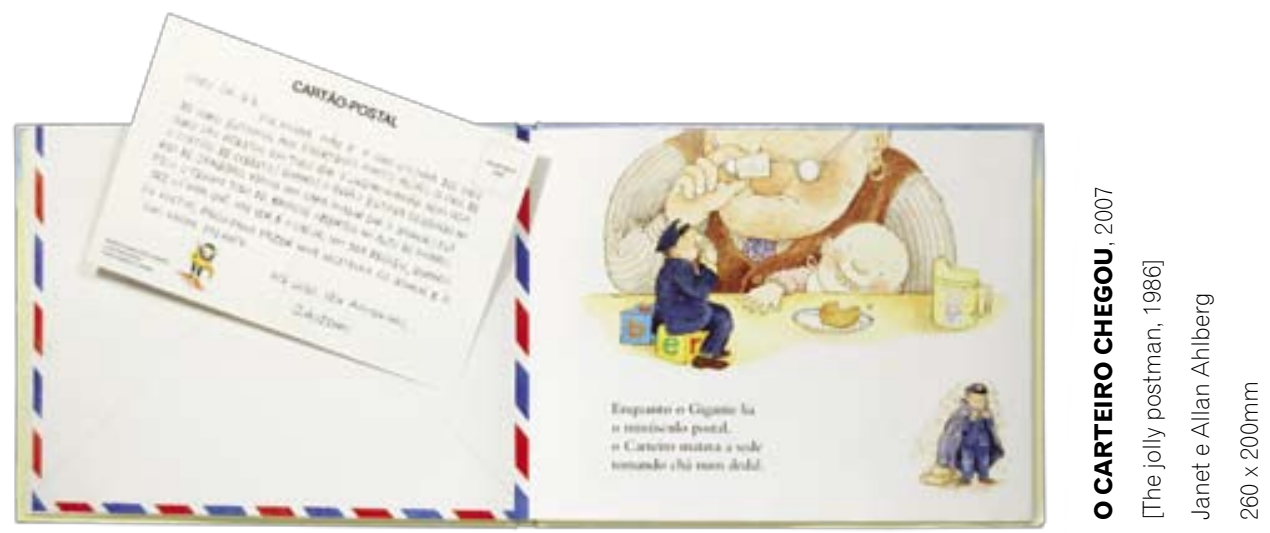

\section{SERRILHA}

Os serrilhados são pequenos cortes na folha de papel, furos ajustados em tamanho e distância, conforme a necessidade de uso. Usados para facilitar a dobra em papéis de gramatura maior ou para a produção de itens destacáveis.

\section{ENCARTE}

Os encartes são peças que se diferenciam no formato do miolo do livro. Durante a encadernação, os encartes são inseridos soltos ou presos. Na lombada canoa, intercala-se o encarte ao miolo por meio de grampos. O encarte pode ser colado no miolo como uma espécie de aba ou pode estar solto.

O carteiro chegou é um livro-objeto em que as páginas duplas são intercaladas com bolsas que contêm folhas impressas soltas, cartas, cartões postais, convites. Objetos que aguçam a curiosidade do leitor e estimulam a imaginação. Cada bolsa imita um envelope de carta destinado a um personagem diferente. Esta é integrada ao livro pelo design e pelo uso da mesma linguagem gráfica. As cartas são peças individualizadas pelo uso da caligrafia ou da tipografia, bem como por seus formato variados.

VINCO

O vinco é um sulco feito no impresso para facilitar as dobras ou o manuseio. As capas de brochura e lombada quadrada possuem um vinco paralelo, para que, durante o manuseio, não forcem o papel. Nos papéis de maior gramatura, os vincos permitem a dobra no sentido transversal da fibra.

O vinco é produzido com o uso de uma lâmina metálica sem corte que quando pressionada marca o papel, semelhante a uma faca especial. Podem ser produzidos vincos de vários formatos e tamanhos, muitos deles são utilizados na produção dos pop-up e das abas-janela. 

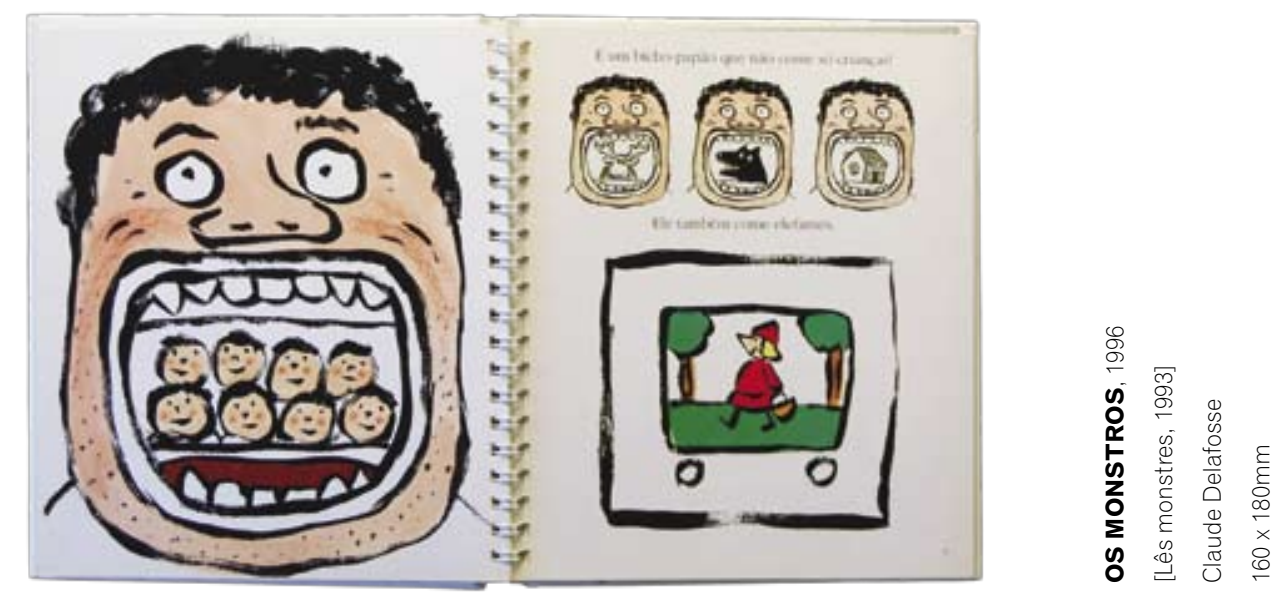

\section{VERNIZES}

O verniz é um material incolor aplicado ao material impresso para o proteger contra desgastes, manipulação e proporcior efeitos de destaque no projeto gráfico. Existem três tipos de acabamento de verniz: fosco, brilhante e acetinado. Além do efeito visual, pode-se trabalhar o aspecto tátil.

O verniz base d'água, ou verniz de máquina, é aplicado no processo de impressão tratado como uma cor a mais. Aumenta a absorção da tinta, funcionando como uma camada protetora para que ela não solte durante o manuseio. Um recurso barato e rápido, porém de baixa resistência à abrasão, podendo, ainda, amarelar com o tempo.

O verniz de alto brilho é utilizado como revestimento de capas. Devido ao seu custo alto, normalmente, substitui-se este acabamento pela plastificação, que confere efeito estático semelhante, realçando a aparência das imagens ou dos elementos gráficos.

O verniz U.V. utiliza luz ultravioleta para a secagem. Devido a seu elevado custo, sua utilização é mais restrita a áreas localizadas no layout, sendo, por isso, denominado de verniz reserva ou verniz localizado. Este verniz fornece uma superfície brilhante ou fosca. Quando combinado com a laminação fosca, potencializa o destaque brilhante.

\section{PLASTIFICAÇÃO}

A função da plastificação é o aumento da durabilidade do impresso, por isso seu uso mais frequente é na capa. Consiste na transferência, mediante calor e pressão, de um filme, geralmente de polietileno, sobre o papel. O papel deve ter entre $75 \mathrm{~g} / \mathrm{m}^{2}$ e $500 \mathrm{~g} / \mathrm{m}^{2}$, mas se recomenda o uso de papel acima de $120 \mathrm{~g} / \mathrm{m}^{2}$ para evitar enrugamentos. Em áreas impressas com tintas metálicas não se pode aplicar esta proteção (VILLAS-BOAS, 2008).

Os monstros é um livro-objeto que propõe o estímulo ao desenho. O leitor é convidado a completar parte das ilustrações com um pincel molhado. As folhas são impressas e recebem plastificação para proteger as páginas da água. O mecanismo interativo é composto 
por uma folha especial, que, quando molhada com água, escurece, e, ao secar, o desenho desaparece. Os recortes especiais nas ilustrações, contornos vazados, permitem que o leitor escolha qual desenho ele quer completar.

\section{LAMINAÇÃO}

O objetivo da laminação, assim como o da plastificação, é a proteção do material impresso com uma película mais aderente e resistente. A laminação é feita essencialmente com filme BOPP, polipropileno biorientado, aplicado à superfície do papel ou cartão por meio de calor e pressão. Não pode ser utilizado em cima de tinta metálica ou serigráfica, pois a alta temperatura prejudica estas superfícies (HASLAM, 2007).

Devido à maior diversidade de insumos, encontra-se, no mercado, a laminação fosca ou brilhante. A laminação fosca fornece um acabamento discreto, contudo tende a diminuir a vivacidade das cores e afeta a definição de pequenos elementos e detalhes.

\section{ENCADERNAÇÃO}

A encadernação refere-se aos variados processos de juntar as páginas ou cadernos de uma publicação. Os diferentes métodos de encadernação possibilitam ao designer explorar os aspectos estéticos da publicação, bem como sua funcionalidade, durabilidade e custo de produção.

O primeiro aspecto que deve ser levado em conta na escolha da encadernação é a durabilidade do livro: a costura é o processo mais durável. Outro aspecto que deve ser considerado é a manipulação, pois a encadernação influencia na flexibilidade da abertura do livro.

\section{ENCADERNAÇÃO CANOA OU GRAMPO}

Lombada canoa ou dobra-e-grampo ou encadernação a cavalo é a forma mais simples e, consequentemente, a mais rápida e barata para a confecção de brochuras. Os cadernos são encaixados uns dentro dos outros, sendo unidos por grampos na dobra.

As publicações com baixo volume de páginas podem ser grampeadas sem sela, enquanto as de maior quantidade devem ser grampeadas lateralmente. O livro grampeado em sela, utiliza um cavalete aberto onde o papel dobrado ao centro recebe $o$ arame que
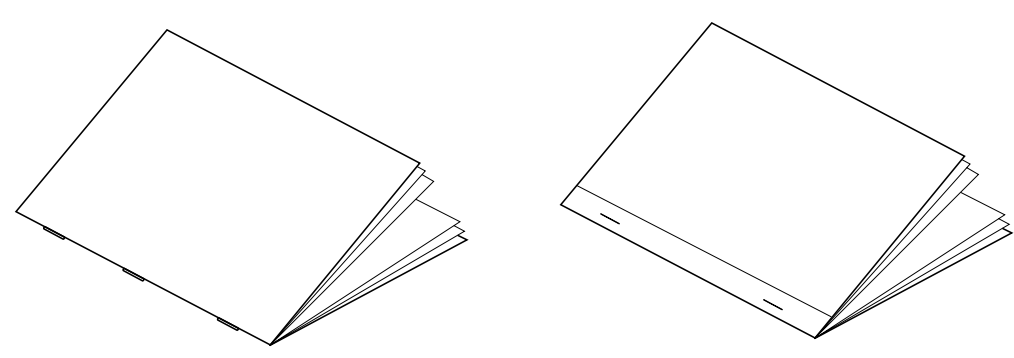


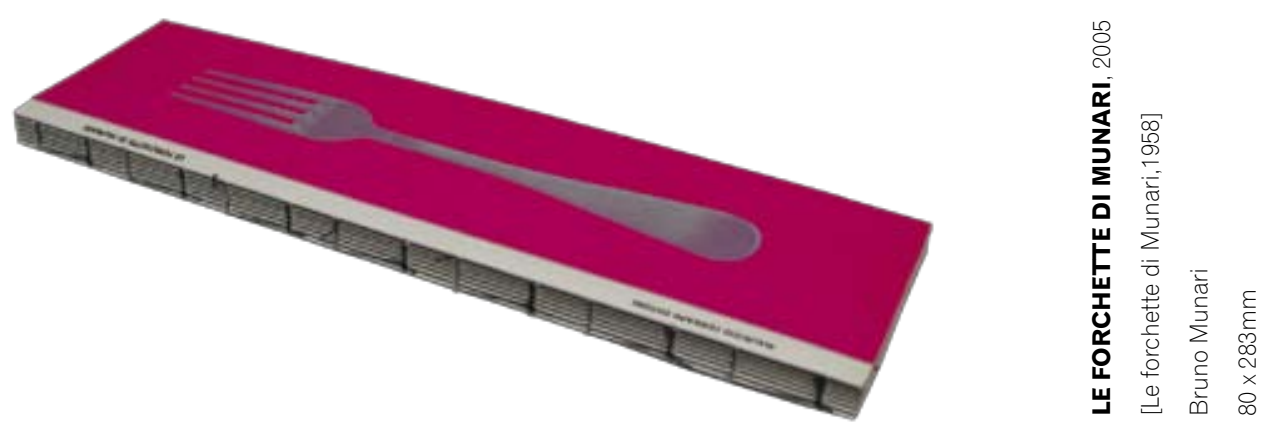

atravessa a lombada de fora para dentro. Os grampos são, automaticamente, fechados por pressão prendendo a capa às páginas do miolo (HASLAM, 2007).

Este tipo de encadernação não é muito utilizado em livros infantis, pois com a manipulação dos livros, as folhas podem soltar-se facilmente e o grampo pode machucar o pequeno leitor.

\section{ENCADERNAÇÃO SEM COSTURA}

A lombada, quadrada ou brochura, sem costura utiliza um adesivo térmico na lombada dos cadernos. Neste processo, a qualidade da cola determinará a durabilidade da encadernação. Os cadernos são intercalados e dispostos em blocos para formar o miolo. No dorso da publicação são feitas fresas por onde é aplicada a fita adesiva, que, quando quente, derrete e penetra nas ranhuras. Uma capa é fixada em torno do miolo.

Em alguns livros-objeto, a costura é substituída pelo processo de empastamento de papéis, normalmente, encontrado na encadernação de papel cartão impresso. A junção de papéis colados possibilita brincar com janelas impressas em ambos os lados da página.

\section{ENCADERNAÇÃO COM COSTURA}

A lombada costurada é o processo mais recorrente nos livros, no qual os cadernos são costurados na dobra das páginas, e se reforça a união dos cadernos com cola. A costura na gráfica é feita por máquinas específicas. A costura pode ser do tipo Smyth, ou costura plana, quando os cadernos abertos pelo centro são costurados com um fio contínuo, não apenas individualmente, mas com os demais cadernos adjacentes. Ou pela costura lateral, utilizada para edições que requerem uma encadernação forte, em que o volume inteiro é costurado a poucos milímetros da lobada (BAER, 2009).

O design do livro pode tirar partido da costura aparente, utilizando-a como elemento estético. Em Le forchette di Munari, a costura aparente preta se destaca nas folhas acinzentadas. Um plástico transparente protege a capa e a lombada costurada. 

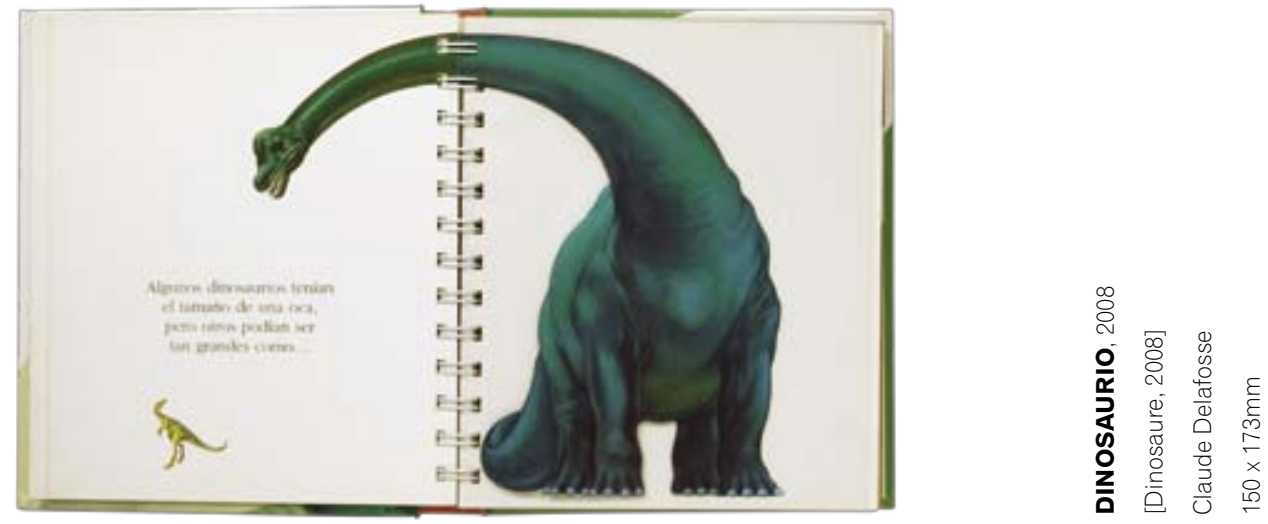

\section{ENCADERNAÇÃO MECÂNICA}

A encadernação mecânica consiste na reunião de páginas pelo encaixe de acessórios metálicos ou plásticos por meio de furos. O mais utilizado processo mecânico é o wire-o. Garras metálicas opostas atravessam a perfuração feita em uma das bordas das folhas e se juntam para encadernar as páginas, e a espiral é inserida nas perfurações ao longo de uma das bordas da página, sendo que esta pode ser de plástico ou metálica. A encadernação wire-o pode ser exposta ou oculta.

O projeto gráfico já deve ser pensado quando receber esse tipo de encadernação para que a interferência dos furos no layout não prejudique a leitura da imagem ou do texto. Uma das vantagens desse sistema é a possibilidade de abrir completamente o volume e articular diferentes lâminas, sem a restrição da divisão por cadernos.

No livro Dinosaurio, o autor tira partido da encadernação mecânica, wire-o, para intercalar folhas de acetato no miolo do livro, estabelecendo um jogo com as imagens escondidas pelo acetato. A costura não viabilizaria o lúdico proposto.

\section{AUTO ENCADERNAÇÃO}

Algumas publicações parecem estar encadernadas, mas a dobra é o único processo de acabamento, tais publicações são conhecidas como auto-encadernadas. Numa dobrasanfona, as duas primeiras páginas podem ser utilizadas como capas, quando dobradas.

Zoo é impresso em duas lâminas únicas, dobradas em sanfona e coladas numa espécie de cruz dobrada para que o leitor possa brincar com as diversas possibilidades da narrativa visual. Não existe uma capa, esta é substituída por uma luva. Este livro-objeto está montado de tal forma que não existe um sentido certo para a leitura, que pode começar do lado que o leitor escolher. Sua manipulação é independente do texto, e cada assunto localiza-se num quadro dobrado. 

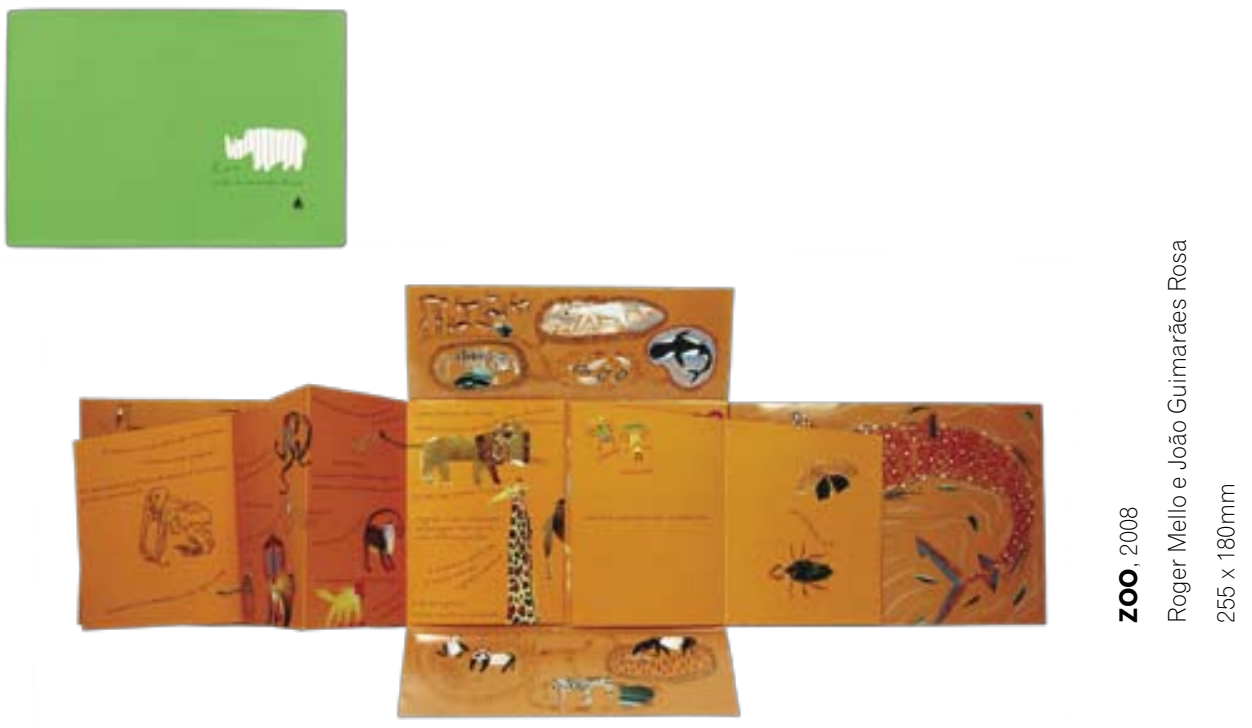

\section{CAPA BROCHURA}

Realizada com o mesmo papel do miolo ou um papel de maior gramatura. A capa é colada diretamente no dorso do volume, sendo do mesmo tamanho do miolo, sem deixar seixo (as sobras laterais). A capa pode ser refilada junto com o miolo ou pode ter duas abas laterais, orelhas dobradas, fornecendo maior resistência mecânica.

\section{CAPA DURA}

A capa dura consiste numa base cartonada ou de papelão sobre a qual é colada uma sobrecapa impressa que reveste o cartão. As guardas, coladas sobre a base rígida, são de papel mais resistente, e podem ou não serem impressas. A capa dura é mais resistente, por isso é a ideal para uma manipulação maior. $O$ diferencial da capa dura é a possibilidade de explorar a aplicação de diferentes materiais no revestimento, como tecido de algodão, couro e plásticos, entre outros acabamentos.

\section{CAPA FLEXÍVEL}

É uma capa intermediária entre a capa dura e a brochura. O processo é semeIhante ao de capa dura, exceto pela substituição do papelão por um papel mais encorpado, normalmente em torno de $250 \mathrm{~g} / \mathrm{m}^{2}$. Trata-se de um processo mais barato que a capa dura, de grande durabilidade ao manuseio, que pode ser encontrado em muitos livros. 
Neste capítulo, resgataremos parte da teoria do primeiro, instrumentos lúdicos, e parte do segundo, design do livro, para aprofundar a análise do livro-objeto infantil. Květa Pacovská e Bruno Munari servirão de estudos de caso, permitindo confrontar a teoria com livros-objeto existentes.

A escolha dos autores se deu pela importância de ambos no âmbito editorial infantil, reconhecidos pelo caráter experimental de seus livros. Em suas obras a manipulação está presente, e o lúdico tem grande importância para seu design.

Pacovská e Munari diferenciam-se pela forma que trabalham graficamente, pela representação das imagens e pelos recursos de produção utilizados. Pacovská exprime em suas obras a influência da sua formação em artes plásticas, enquanto Munari explora um desenho icônico mais próximo da linguagem utilizada em design gráfico.

Munari tem sua produção editorial infantil iniciada em meados de 1950, seus livros apresentam soluções gráficas inovadoras para sua época, o que criou, por vezes, dificuldades para publicar tais obras. Já os trabalhos de Pacovská aqui estudados datam do início do anos 1990.

A análise das obras orientou-se pelos critérios de design discutidos no capítulo anterior: formato, tipografia, organização da página, linguagem visual das ilustrações e produção gráfica.

\section{KVĚTA PACOVSKÁ}

Pacovská nasceu em 28 de julho de 1928 na República Tcheca, onde vive atualmente. Formada em artes na Escola de Artes Aplicadas de Praga, iniciou sua carreira como ilustradora de livros em 1950.

Trabalha nas mais variadas artes, pintura, design, escultura, poesia e performance. Este trânsito permitiu unir diferentes técnicas, expressões que desenvolveu ao longo de suas obras, colagens, recortes, cores especiais e predomínio de formas geométricas. Possui mais de sessenta livros publicados, nos quais se destacam: 
Karlicka a bily konik, 1968

Nevy Plasuj Jazy na Lva. Albatros, 1974

Bile Vrany. 1975

Devcatko Momo a ukradeny cãs, 1979

Jednicka z Provazku. Albatros, 1984

Jak se Hraje na Divedere. Albatros, 1984

Rumpe/stilzchen erzahlt, 1986

Tri Kotatka, 1987

Kocici Kral. Albatros, 1989

Jamais deux sana trois. Seuil, 1990

Der Kleine Blumenkönig, 1991

Mitternachtsspie/. Michael Neugebauer Verlag, 1992

Grün rot alle. Ravensburger, 1992

Rund Und Ecking. Ravensburger, 1994

Alphabet. Seuil, 1996

Flying. North South Books, 1996

Es War Einmal Eine Blume. Neugebaur Verlag, 1998

Rotrothorn. Ravensburg, 1999

Unfold/ Enfold. Seuil, 2005

Rotkäppchen, 2007

Hänsel und Gretel, 2009

Cendrillon. Mineditions, 2009

Pacovská ganhou inúmeros prêmios, entre eles: Hans Christian Andersen em 1992; Golden Apple do BIB; Premi Catalonia de Barcelona; Golden Letter em Frankfurt; Silver Brush em Amsterdã; Graphic Prize em Bologna; Johann Gutenberg Prize em Leipzig; e Sankei Children's Book Culture Award em Tokyo. Realizou exposições em museus e galerias importantes na Inglaterra, Japão, França e Itália.

Seu trabalho é marcado pelo experimentalismo e pelo cuidadoso uso dos recursos de produção gráfica. Pacovská acompanha a produção de cada livro, utilizando as tecnologias disponíveis na indústria gráfica.

A partir da década de 1990, Pacovská passa a desenvolver técnicas que aguçam a manipulação da narrativa visual. Os livros ganham sofisticação, tridimensionalidade, relevo, brilho e outros recursos que despertam a contemplação do leitor. Seus livros são acessíveis a qualquer leitor, independentemente de sua idade. Grande parte deles é classificado como picture book, livro em que a compreensão é obtida pela junção de texto e imagem durante a leitura, em vários utiliza-se dos recursos gráficos para criar imagens nonsense.

Apesar de a narrativa ser categorizada como picture book, parte da sua produção atual pode ser considerada como livro-objeto infantil. Estes apresentam recursos de manipulação como facas especiais, dobras e impressão diferenciada.

Muitos dos temas retratados em seus livros são provenientes dos contos de fadas, extraídos dos livros dos irmãos Grimm e de Andersen, como Chapeuzinho Vermelho, João e 

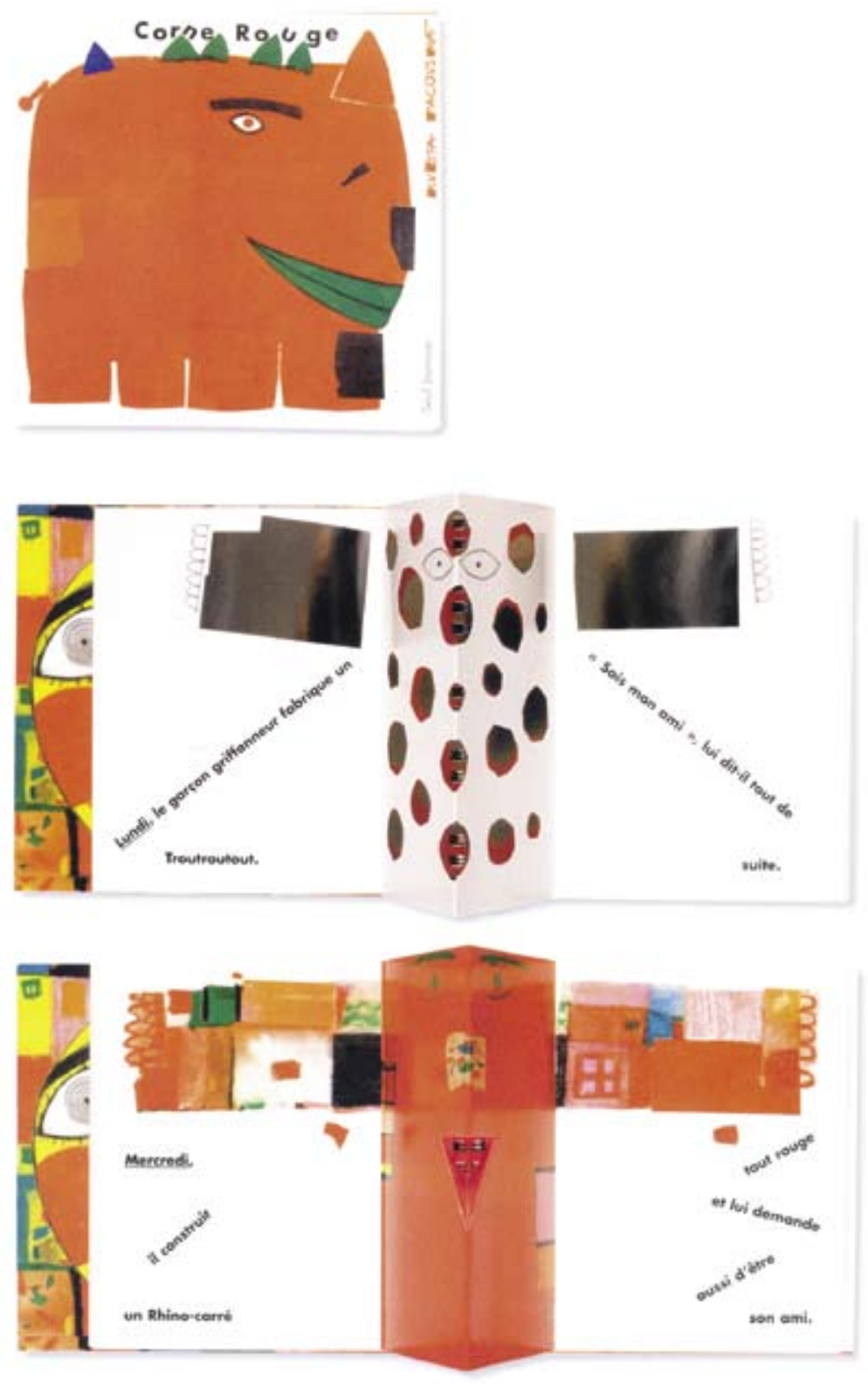

Maria, e Cinderela, entre outros. Em suas recentes publicações, a autora trabalha temas ligados à aprendizagem, como por exemplo o alfabeto e os números, mostrando como aplicar a originalidade visual a partir do quotidiano infantil.

Pacovská desenvolveu um estilo de ilustração que é fácil de se reconhecer, com o predomínio de formas geométricas, cores vivas e contrastantes. O desenho de seus personagens alterna da cor chapada à mistura de técnicas, como o recorte e a colagem.

A escolha dos livros para a análise baseou-se nos seguintes critérios: ser um livroobjeto, apresentar inovações visuais e ser um objeto instigante para o leitor. Os exemplos analisados possuem uma cuidadosa produção gráfica, acabamentos que implicam no lúdico. 


\section{ALPHABET}

Ravensburger Buchverlag, 1996

$240 \times 235 \mathrm{~mm}$

brochura wire-o

offset 5 cores

impresso na Alemanha
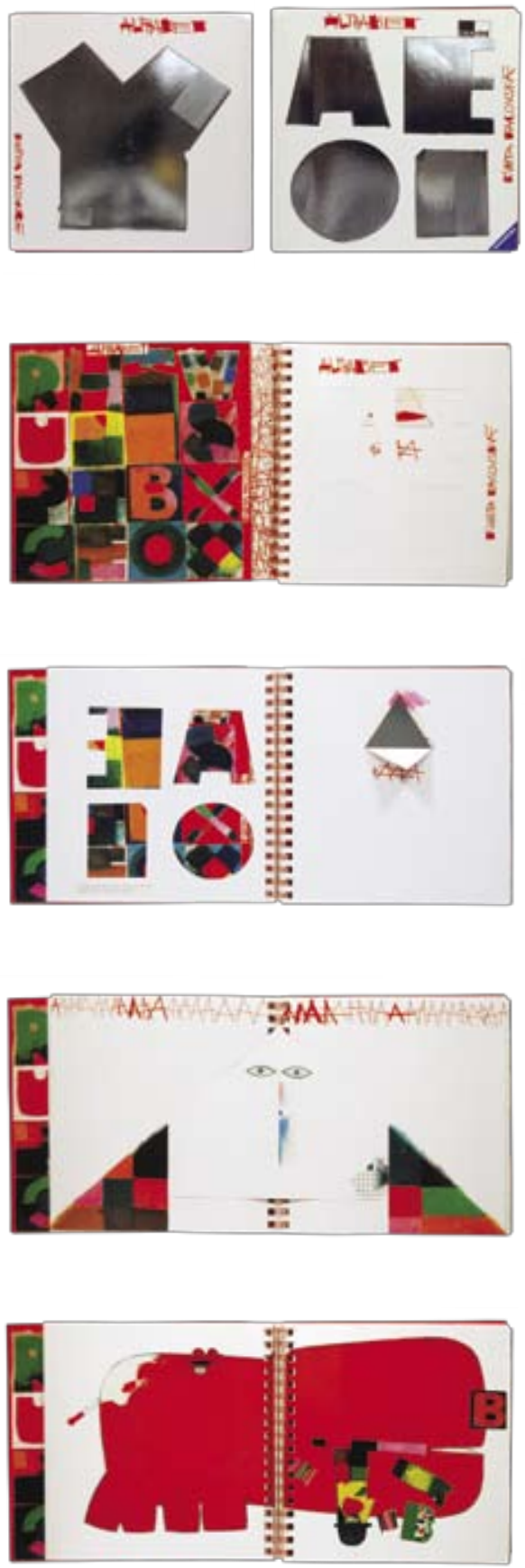
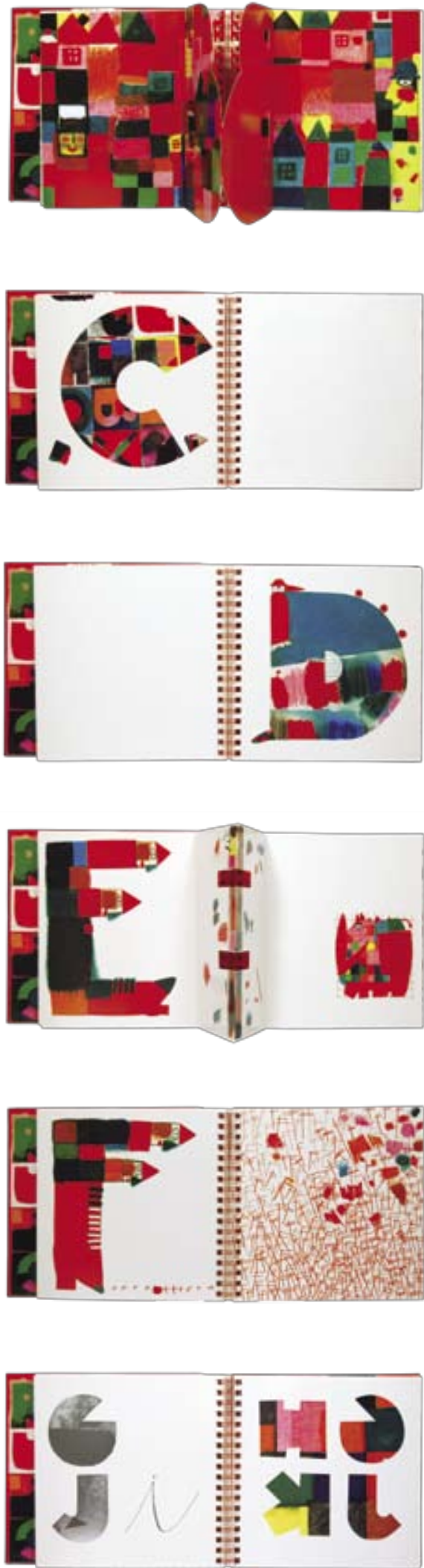

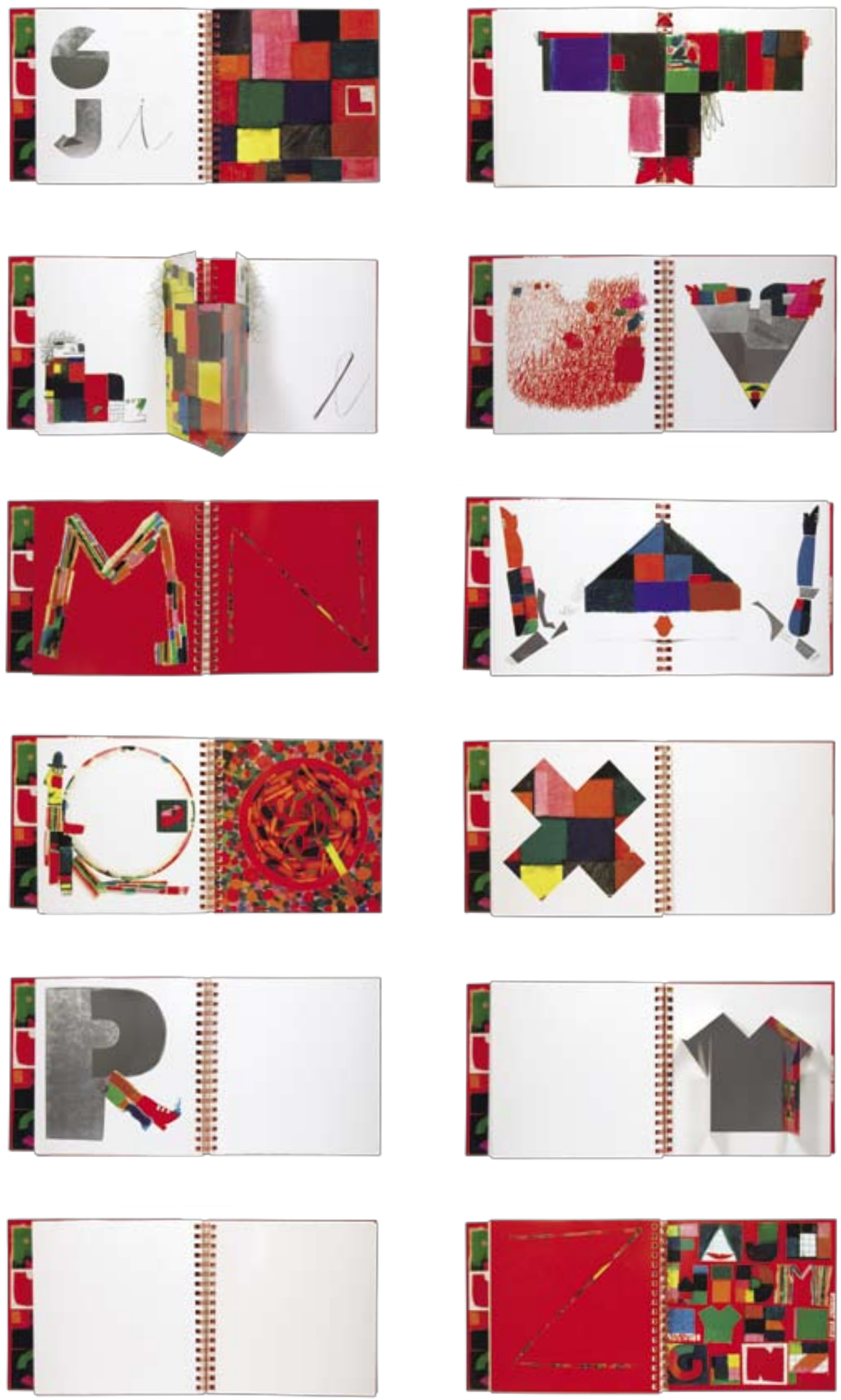


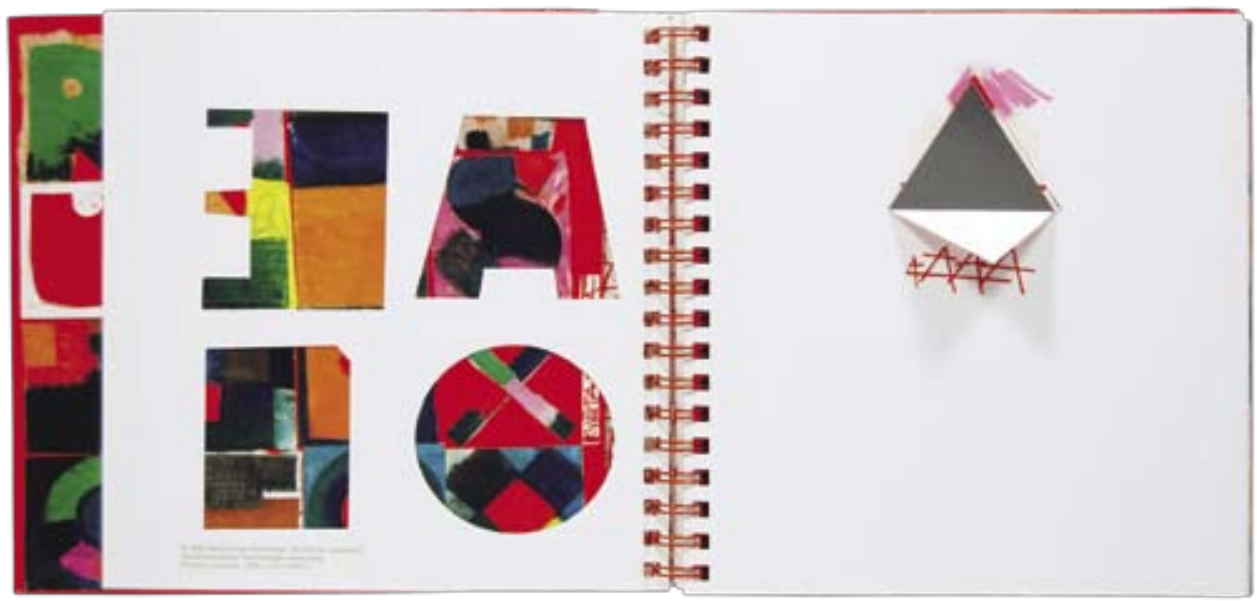

O tema do alfabeto é recorrente no meio editorial infantil, por sua importância na formação de novos leitores. Diferente dos livros usuais sobre este tema, Pacovská trabalha as letras do alfabeto como uma narrativa visual, com predomínio do experimentalismo gráfico.

Alphabet configura-se pelas diversas expressões visuais associadas ao uso contrastante das cores e a uma produção gráfica cuidadosa. As cores fortes e vibrantes estão presentes tanto na relação figura e fundo como na sequência narrativa. A impressão em alto-relevo dá continuidade à página carregada de cores, convidando o leitor a sentir a letra pelo tato.

O alfabeto é apresentado em diversas expressões visuais, ora figurativas ora descritivas. Algumas letras são distribuídas em uma única página, enquanto outras em mais de uma página-dupla, sem qualquer explicação lógica, movidas aparentemente pelo experimentalismo estético.

O formato das letras desenha personagens, bem como delimita um conjunto de colagens, contorno invisível da forma. As ilustrações são construídas pelo predomínio das figuras geométricas: triângulo, retângulo e circunferência.

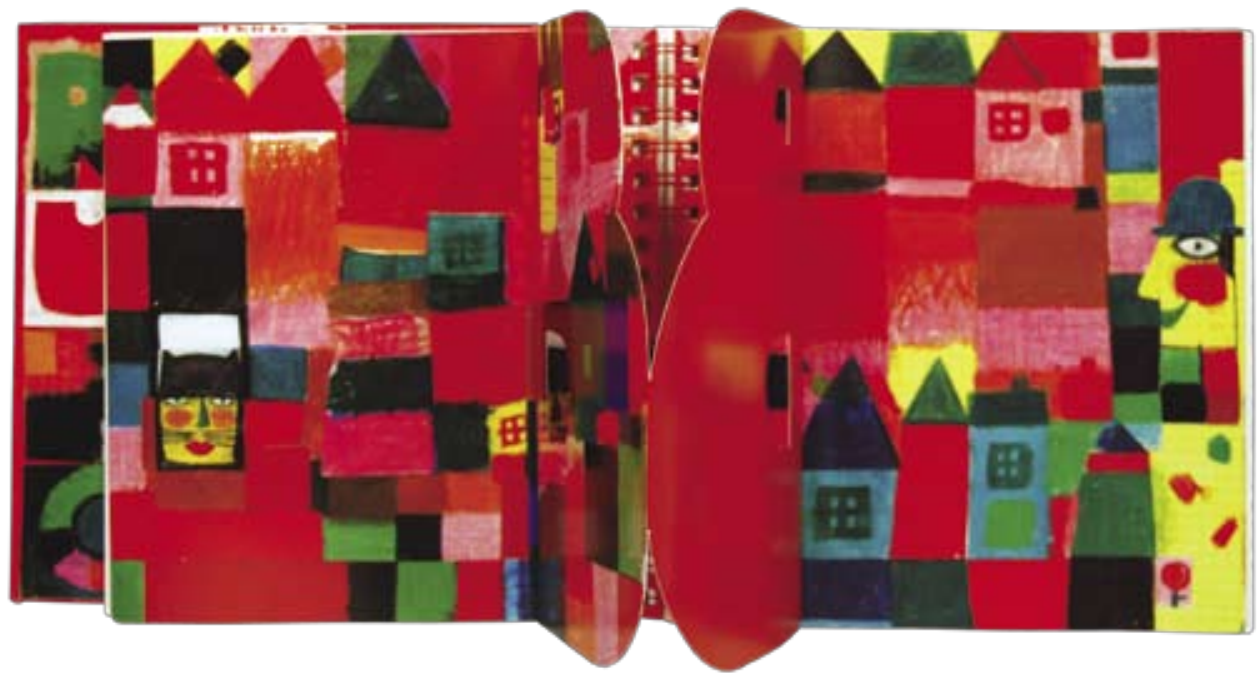


O lúdico proposto neste livro se encontra nos jogos com recortes. A autora utiliza a faca especial para criar letras vazadas, assim como para criar alguns letras em pop-up. 0 leitor percorre página a página em ritmos de leitura diferentes.

O lúdico não aparece apenas nos recortes, Pacovská trabalha, em determinadas letras, a sinestesia na textura e no alto-relevo. Além do aspecto tátil, a autora pensa na sonoridade das letras, a abertura da boca para pronunciá-las. Esta intenção de projeto é explícita no livro-catálogo, À l'infiniti, onde tal relação é demonstrada.
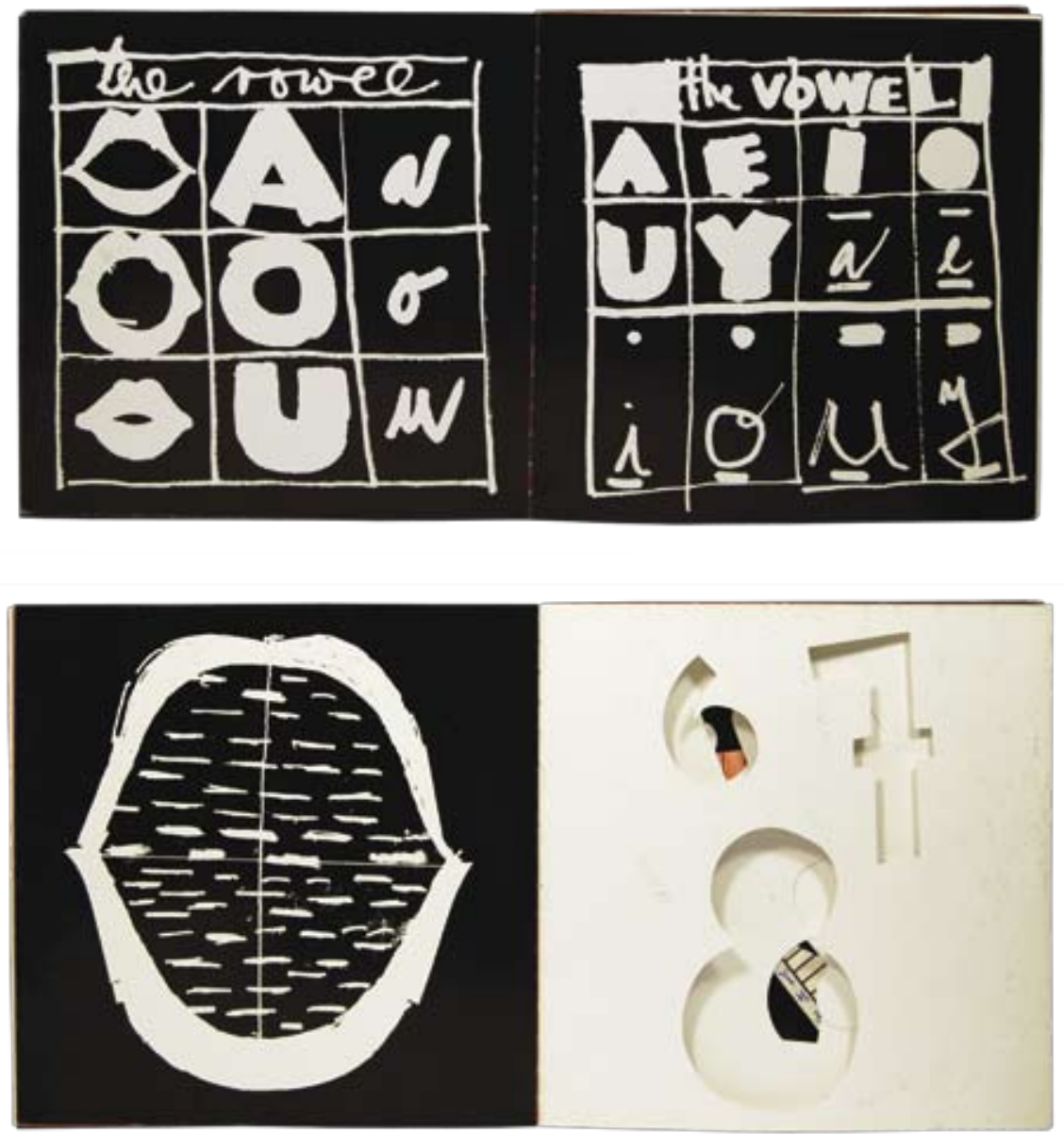

\section{FORIMATO}

Alphabet apresenta um formato quase quadrado, na proporção 228 × 232mm. Algumas páginas são dobradas ao meio e impressas de ambos os lados. Dessa forma, tem-se uma nova leitura por meio dos recortes vazados e pelo espaço entre o mecanismo de pop-up.

As páginas são impressas como lâminas soltas e, posteriormente, unidas pela encadernação wire-o. O aproveitamento do papel torna-se maior, porque o posicionamento das páginas não se limita pelas dobras e formação dos cadernos, e a produção gráfica se viabiliza com facilidade, o que resulta num produto de menor custo. 

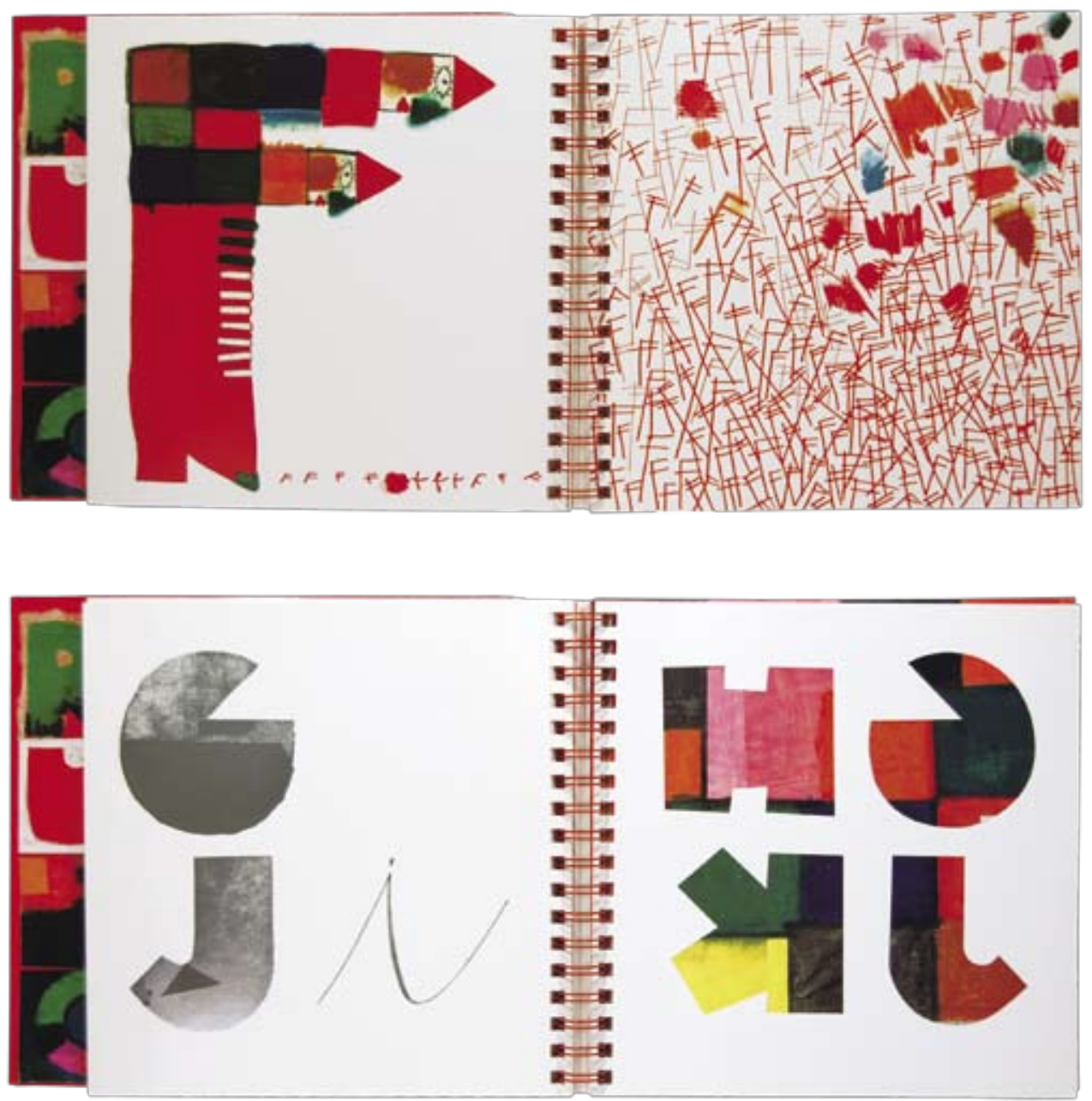

TIPOGRAFIA

A tipografia utilizada é extraída de formas geométricas ou manuscritos da própria autora. Uma vez que há ausência de texto narrativo, os tipos trabalham explorando a plasticidade da forma.

O título e nome da autora são desenhados por Pacovská com uma caneta vermelha, bem como as letras, A, F e V, que aparecem em um conjunto manuscrito aplicados como textura gráfica.

Os tipos predominam em caixa alta, desde o título às letras individualizadas, e num formato que equivaleria a uma família tipográfica bold. A única letra desenhada em caixa baixa é a "i", esta manuscrita a lápis sem uma espessura considerável. 


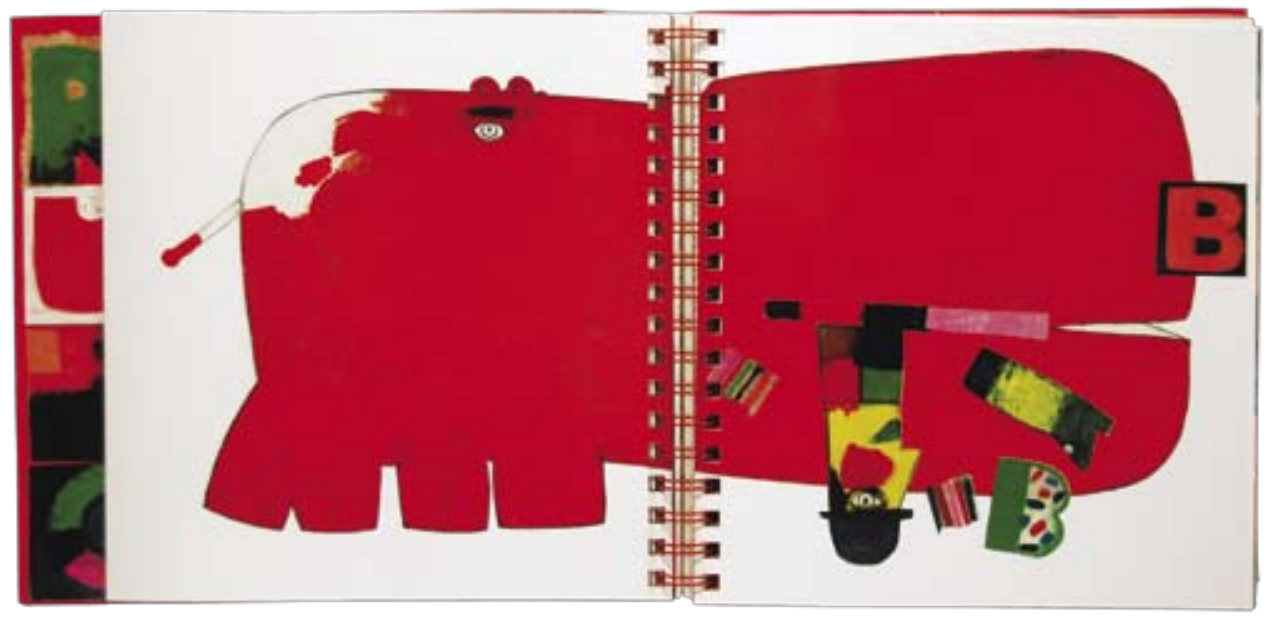

\section{ORGANIZAÇÃO DA PÁGINA}

O formato quadrado permite dispor cada letra num campo quadrado, pois as letras em caixa alta preenchem quase totalmente a página. As imagens obedecem a uma diagramação centralizada nas posições horizontal e vertical.

A malha é inexistente, as imagens são posicionadas conforme a forma do desenho. A ilustração aparece sangrando na página em alguns casos, mas predomina uma margem de $15 \mathrm{~mm}$ em todos os lados.

O impacto da cor versus a forma da figura orienta a distribuição dos elementos. Quase todas as páginas são compostas por elementos únicos, que ocupam cerca de oitenta por cento do campo. Os detalhes presentes são parte da figura maior, assegurando uma página visualmente mais limpa, apesar do uso de cores fortes e contrastantes.

\section{LINGUAGEM VISUAL DAS ILUSTRAÇÕES}

No fundo das páginas, predominam o branco e o vermelho chapados, trabalhados sempre em pares de contrastes. As cores vibrantes, marca registrada da autora, aparecem também nos personagens-letra.

O vermelho predomina nas ilustrações, bem como participa do fundo impresso das páginas dobradas, visível através dos vazados das letras tridimensionais. A cor exerce o papel de separador do campo visual, presente também na divisão das páginas por meio da encadernação wire-o na cor vermelha.

A textura participa como ilustração, aparece como grafismo visual e como elemento tátil. Um recurso explorado pela autora, o relevo seco, convida o leitor a explorar uma sequência desordenada de pontilhados que preenchem as letras D, S e X, e simula uma textura artesanal.

As formas das letras baseadas na junção de formas geométricas desenham os personagens desta narrativa. As letras ganham forma por meio da técnica do recorte e colagem, o que resulta numa imagem sem contorno evidente. As técnicas associadas, lápis, pastel, caneta e tinta, compõem a textura das ilustrações. 


\section{PRODUÇÃO GRÁFICA}

Este livro apresenta diversos recursos de produção gráfica, aplicados com critérios diversos para enriquecer visualmente as páginas. Algumas decisões de projeto, como a encadernação wire-o, acabam por definir as soluções adotadas no miolo, entre elas a utilização de uma folha impressa dos dois lados e dobrada ao meio.

Se por um lado algumas páginas tiram partido da encadernação wire-o, outras acabaram prejudicadas, como o pop-up da letra A, que quando aberta na totalidade não possibilita a tridimensionalidade. No livro À l'infiniti, Pacovská soluciona a volumetria com a adição de pontos de dobra e cola.
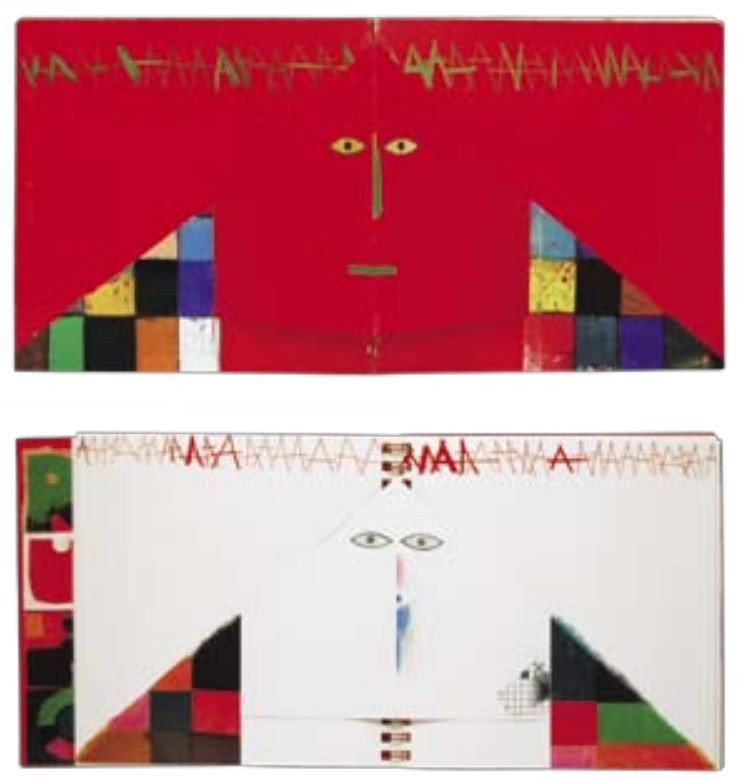

Alphabet é impresso em offset utilizando-se de cinco cores, na intenção de produzir um vermelho mais intenso, que se destaca sobre as outras cores provocando diferentes pontos focais. Utiliza-se papel similar ao couché de gramatura superior a 180g, espessura suficiente para suportar as facas especiais e estruturar o pop-up.

O hot stamping prata é utilizado em áreas específicas e na capa para produzir destaque visual. A autora explora no prateado texturas diferenciadas. Na letra Y, o prateado ganha outra dimensão, possibilitando o reflexo da pintura escondida na janela, assim como explorado na letra $A$.

O relevo a seco, alto-relevo, aplicado para dar corpo em algumas letras, preenche o desenho com qualidade tátil. As letras D, S, e X apresentam-se na forma de pontilhismo e as letras $\mathrm{N}$ e T, na forma de um relevo homogêneo.

Pacovská tira partido da folha dobrada ao associar o mecanismo de recorte especial e alguns pontos de cola para criar o pop-up. Se por um lado os pop-up das letras A, Te W não funcionam quando abertos na totalidade, por outro, nas letras $E$ e L obtêm-se um efeito diferenciado. 


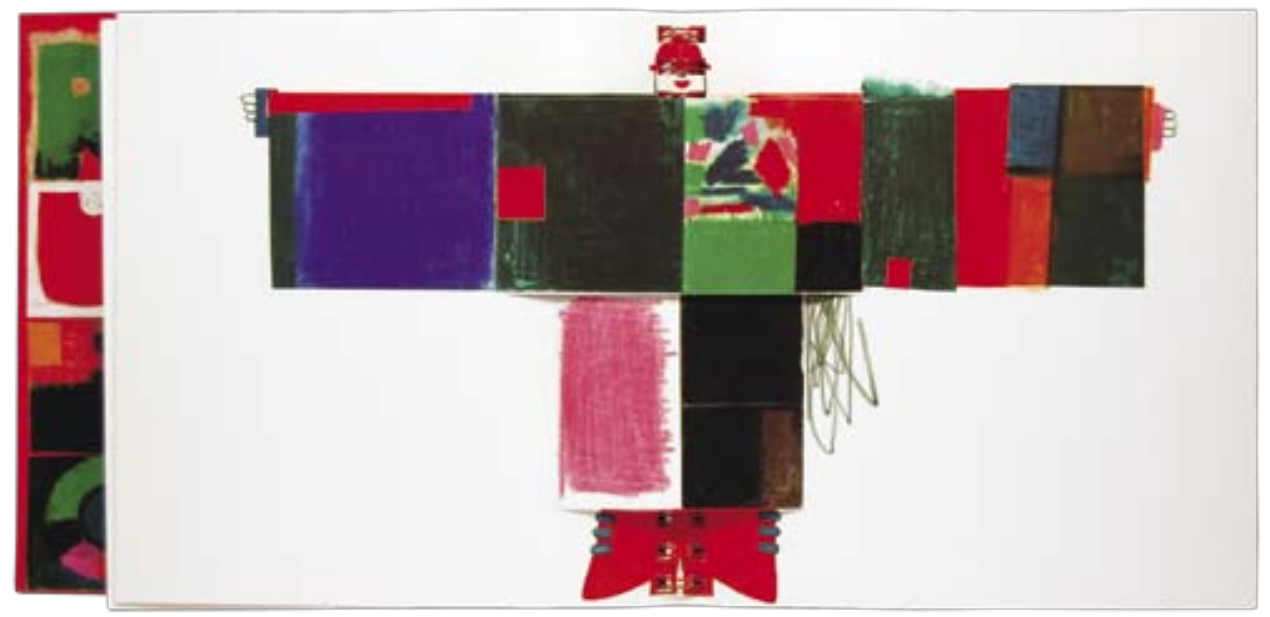

A faca especial é utilizada, além da produção dos pop-up, no destaque de um conjunto de letras, na brincadeira com janelas para produzir as letras A e Y. O recorte da letra vazada brinca com a pronúncia das letras, o que justifica a presença do $\mathrm{H}$ recortado em papel branco que, quando sobreposto no fundo de mesma cor, desaparece.

A capa é composta pelo mesmo papel do miolo, impresso em ambos os lados e, posteriormente, dobrado. Dessa forma, a capa com lombada quadrada esconde e protege o wire-o. Na parte interna das orelhas, a autora brinca com o desenho do "A" na capa e com o "Z" na quarta-capa. As orelhas fornecem à capa maior resistência física. O livro vem embalado em uma caixa de cartão, similar a uma lupa, impresso com as mesmas ilustrações das orelhas.
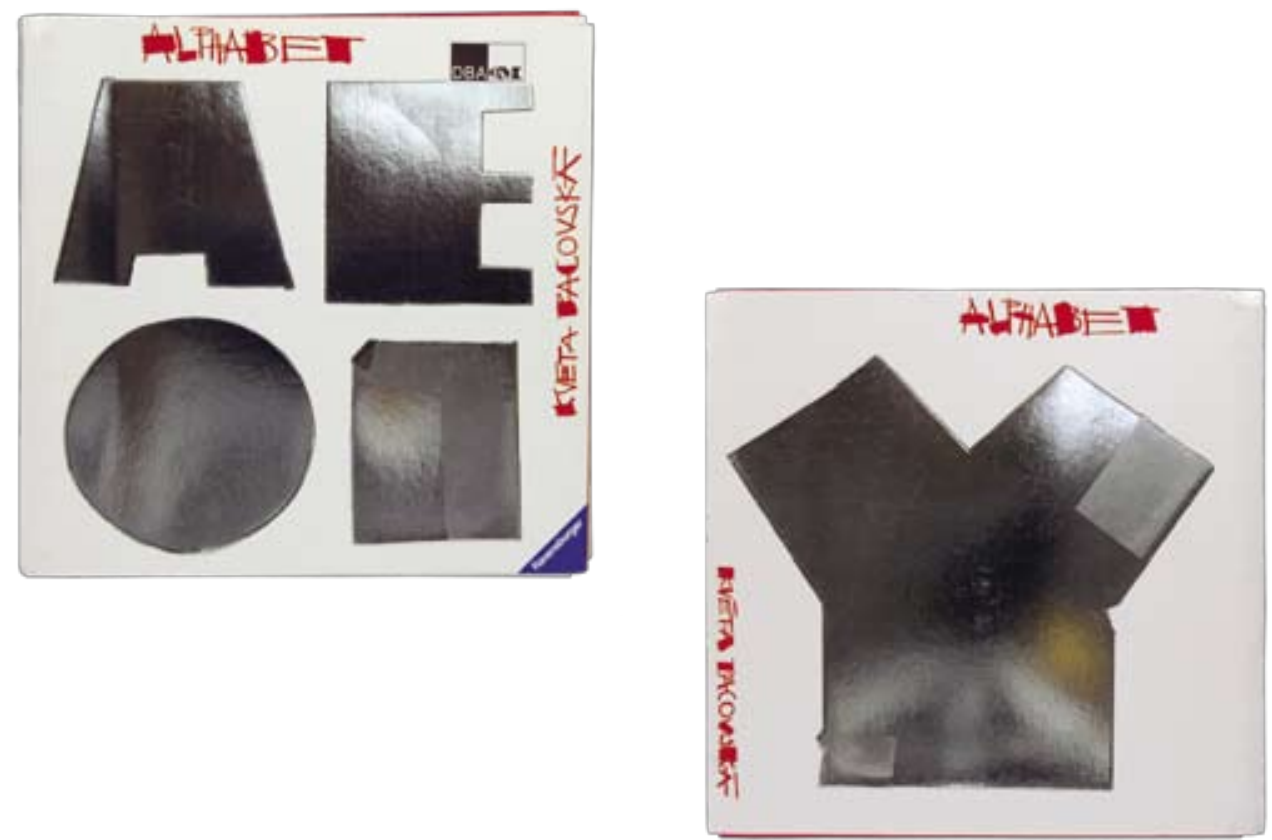
JAMAIS DEUX SANS TROIS

Éditions Du Seuil, 1996

$195 \times 270 \mathrm{~mm}$

brochura wire-o

offset 4 cores

impresso na Alemanha

\section{[Eins, fünf, viele}

Ravensburger Buchverlag

Otto Maier, 1990]
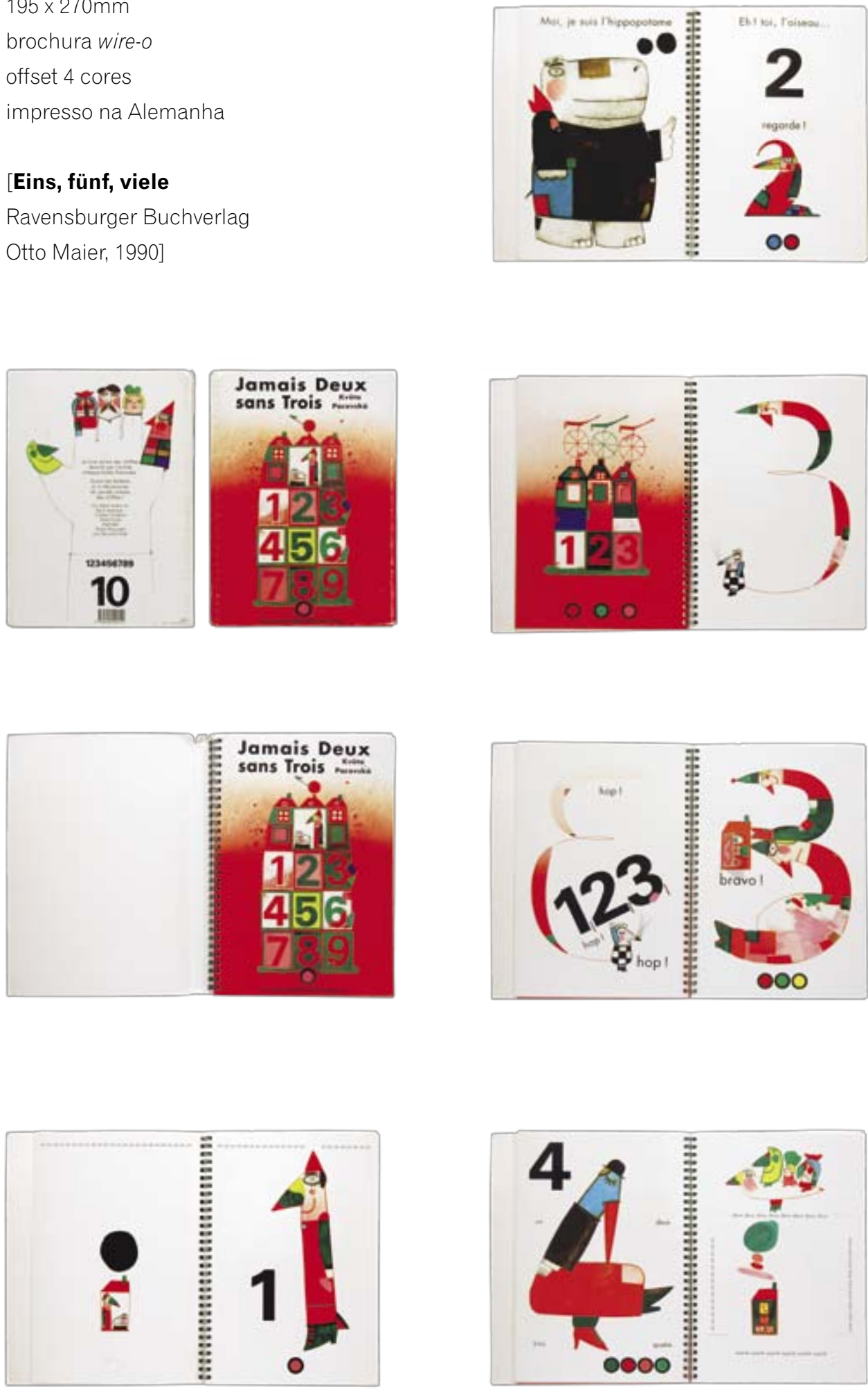

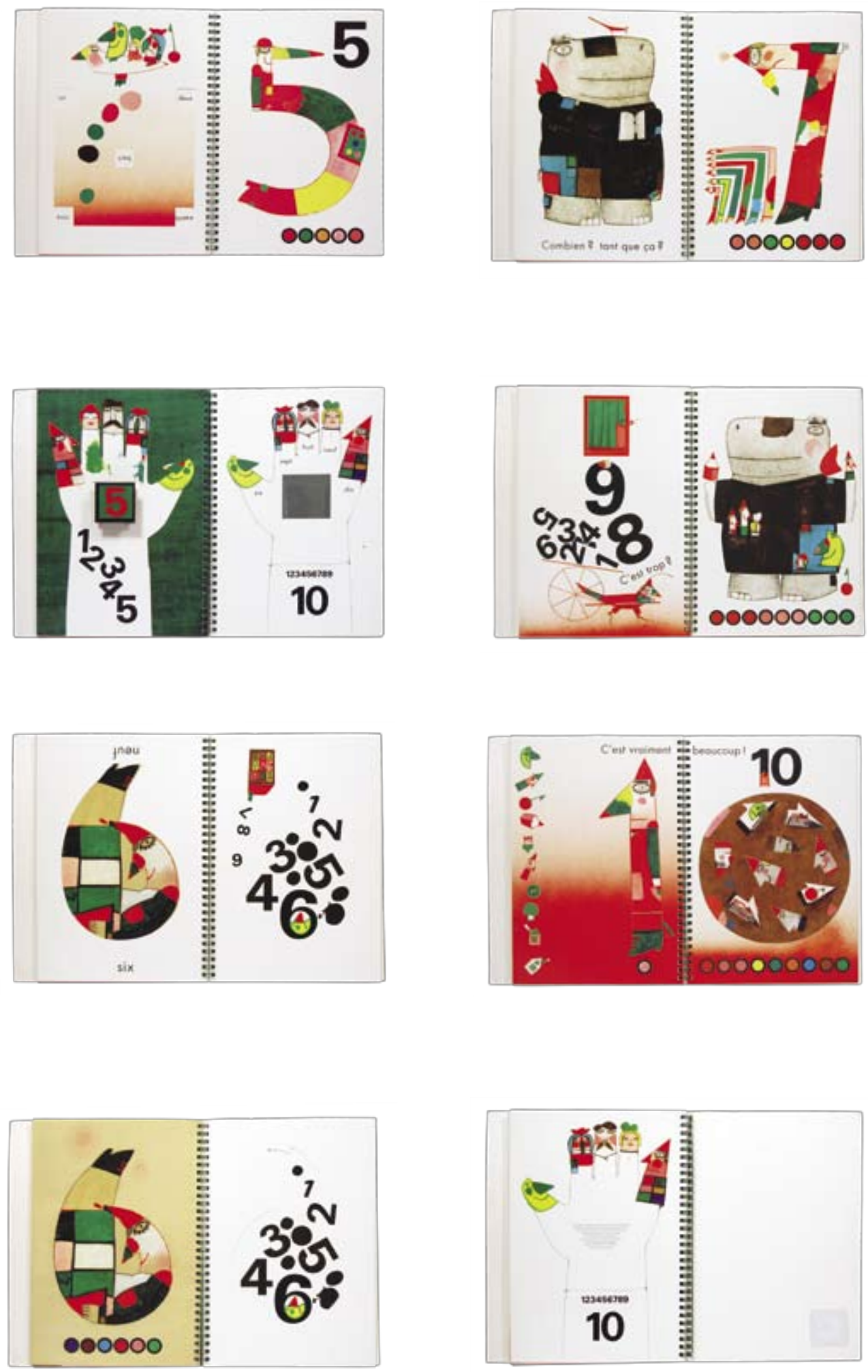

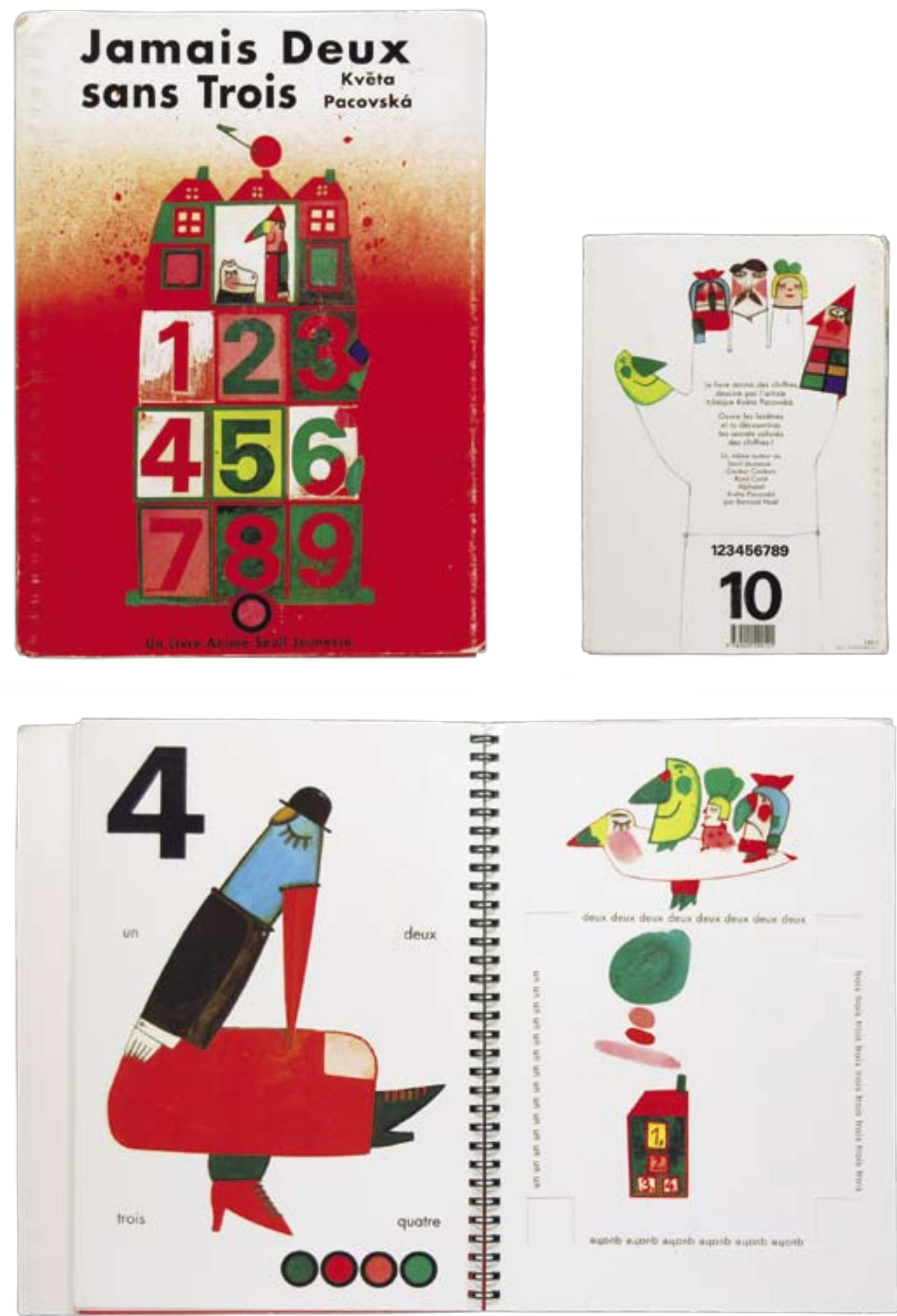
Jamais deux sans trois é uma narrativa visual, na qual os números são o eixo norteador. Tema recorrente no meio editorial infantil, semelhante ao alfabeto, é classificado como educativo para os leitores em formação. Neste trabalho percebe-se que os números são pretextos para o experimento visual desenvolvido.

Pacovská realizou este livro antes de A/phabet, se assemelharem em algumas soluções de projeto, como a encadernação e a utilização da folha impressa dobrada, Jamais deux sans trois tem a mesma sofisticação de recursos da indústria gráfica.

Este livro apresenta, numa contagem progressiva, os números de um a dez, sendo destinada uma página-dupla para cada número. Durante a progressão, a autora utiliza-se de intervalos que servem para a assimilação das informações apresentadas, bem como de preparação e criação de expectativa para a página seguinte.

Os números aparecem na página em configurações diversas: na forma tipográfica, no formato de personagens desenhados, em formas de círculos coloridos e na quantidade de vazios recortados. A autora explora os meios de comunicar os números, a mensagem, misturando o figurativo com o textual.

O lúdico está presente nos recortes, na brincadeira com as janelas e nos vazados fornecidos pelas facas especiais, nas texturas e nos relevos escondidos nas ilustrações. Nas janelas se encontra o encantamento por meio da manipulação: o passar a mão para descobri-las e a surpresa do olhar por detrás da aba.

\section{FORIMATO}

Jamais deux sans trois apresenta o formato retrato nas dimensões $185 \times 270 \mathrm{~mm}$. Apesar da proporção não fornecer uma razão geometricamente conhecida, seu tamanho é pertinente ao manuseio proposto. Algumas páginas, de dimensões 370 × 270mm, são dobradas ao meio e impressas em ambos lados, o que permite esconder a ilustração em janelas.

Assim como em Alphabet, este livro é impresso em lâminas soltas, que posteriormente são unidas pela encadernação wire-o. O aproveitamento do papel é grande, uma vez que o posicionamento das páginas não se limita pelas dobras e formação dos cadernos. A proporção do livro viabiliza o uso de personagens verticais, explorando a maior expansão possível do texto no espaço da página.

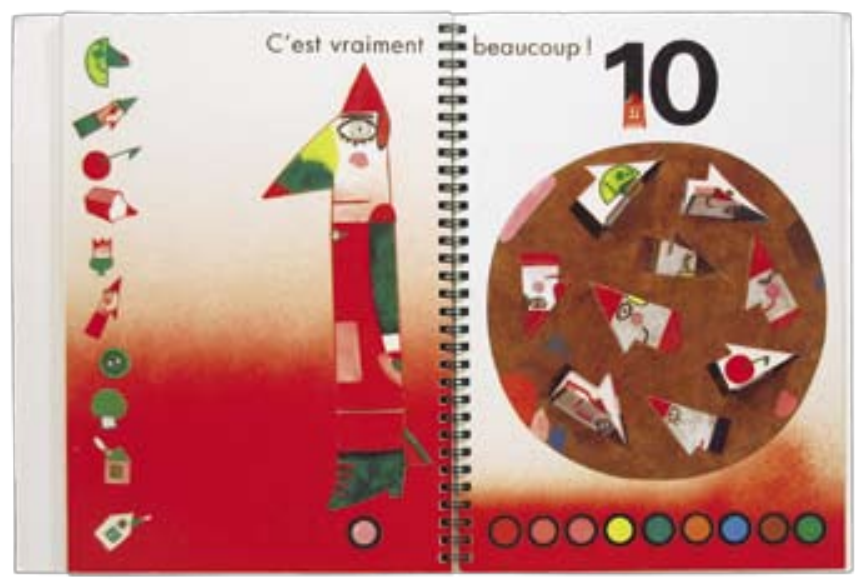




\section{TIPOGRAFIA}

Duas famílias tipográficas são utilizadas neste livro, Futura e Univers. O texto é composto em Futura medium, enquanto todos os números são compostos em Univers bold, altura de corpo variado, sendo que a maior está no corpo 210 pontos. A altura do corpo, no texto, varia ao longo de todo o livro, do menor, 12 pontos ao maior, 32 pontos. No corpo menor, a autora trabalha o texto como textura gráfica, repetindo a mesma palavra inúmeras vezes até preencher uma linha. O corpo maior imprime o peso do número trabalhado.

A tipografia é também expressa na forma artística. Pacovská desenha a forma dos números por meio da ilustração de personagens compondo divertidas imagens, bem como utiliza os números manuscritos dentro das ilustrações, agregando detalhes às ilustrações.

Devido à característica do texto, pequena massa textual, as frases são compostas em uma única linha, sem divisão de parágrafos, o que torna o uso da entrelinha inexistente.

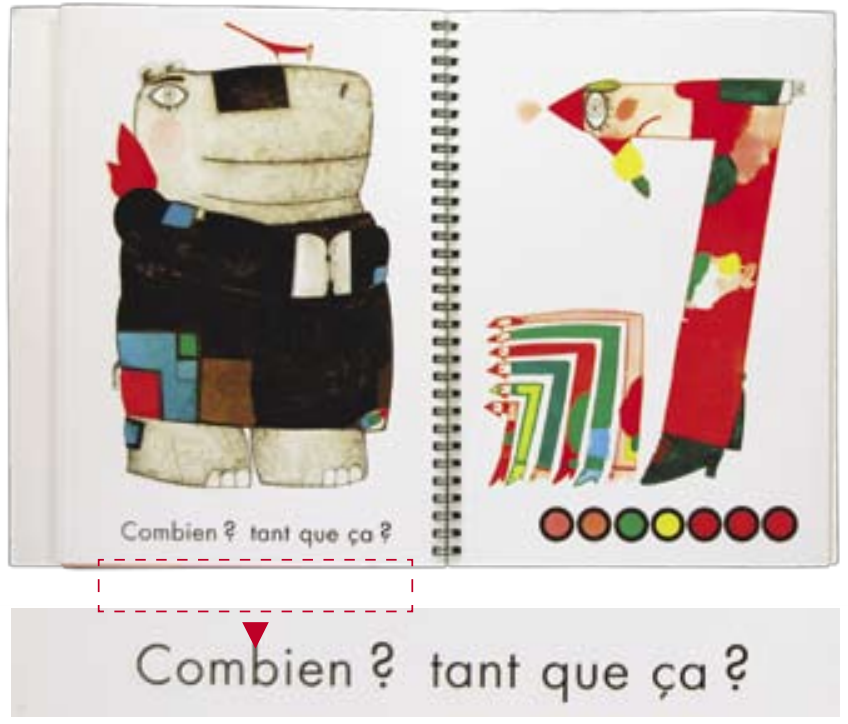

\section{ORGANIZAÇÃO DA PÁGINA}

A diagramação deste livro não é regida por uma malha estrutural, as informações estão dispostas pela hierarquia visual. Apesar de não obedecer a malha, alguns elementos mantêm-se nas mesmas posições da página, como por exemplo os círculos coloridos que estão sempre colocados na parte inferior da página.

As frases predominantemente iniciam na página ímpar da dupla. Trabalhadas como blocos centrais e diagramadas no canto superior ou inferior da página, obedecendo a um mesmo tamanho padronizado de corpo tipográfico.

Os elementos dispostos na página são posicionados ao centro, então, a cada página temos um eixo vertical que organiza as informações gráficas, texto e desenho. A quebra da diagramação justifica a busca pelo equilíbrio visual. 

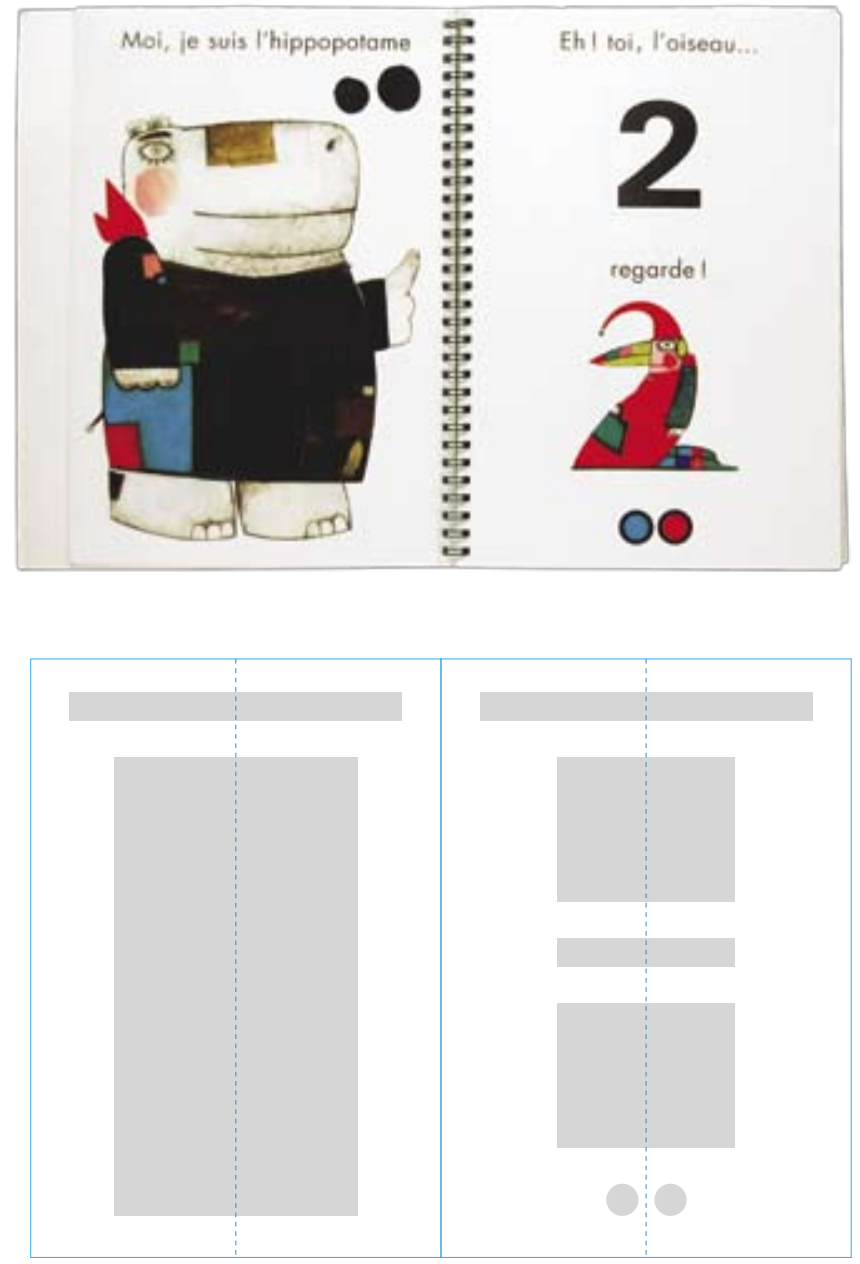

Ao longo da obra percebe-se a não homogeneização das manchas gráficas. Em algumas páginas, Pacovská obtém o equilíbrio visual por meio da economia de informações, em outras a somatória de elementos de mesmo significado sobrecarrega o olhar do leitor.

\section{LINGUAGEM VISUAL DAS ILUSTRAÇÕES}

Pacovská utiliza técnicas mistas para ilustrar este livro, que vão da pintura à colagem. Seus desenhos são marcados por elementos geométricos, semelhante à sua produção.

As cores aplicadas nos personagens predominantemente o vermelho, o verde, o amarelo e o marrom contrastam com o fundo branco. $\mathrm{O}$ vermelho marca presença nesta obra, mas outras cores como o verde e o marrom escuro ganham espaço na composição dos personagens. O verde e o bege, utilizados de fundo na página ímpar, contrapõem com o branco da sua dupla. Nota-se que nestas páginas o lado par e o ímpar têm desenho de contorno semelhante.

As ilustrações caracterizam-se pelo contorno fino e estão presentes em todos os personagens. Uma série de elementos compõe cada desenho, semelhantes a uma colcha de 


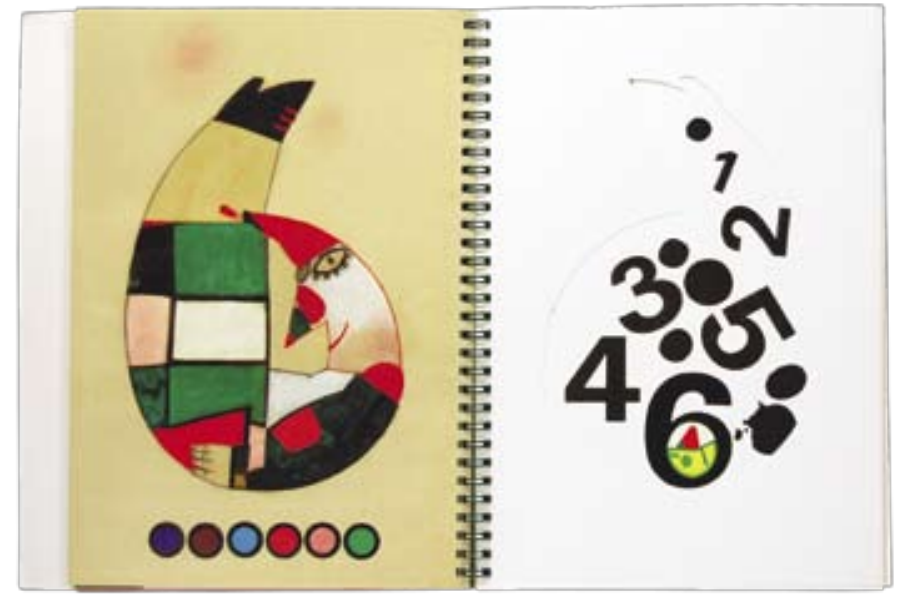

retalhos, a que, partindo de uma forma básica, adiciona-se detalhes coloridos. Esta maneira peculiar de compor marca os trabalhos de Pacovská.

Alguns elementos são recorrentes ao longo da narrativa, como por exemplo os círculos coloridos representando a quantidade de números descrita na página. Outros dois personagens são reincidentes na narrativa, o hipopótamo e o homem com nariz e chapéu triangular.

Os números distribuídos ao longo das páginas são considerados parte da ilustração, elementos da composição visual de cada dupla. A autora destaca a cada par de páginas um número em preto com o corpo grande, que assim estabelece o ponto focal, funcionando como um título para a página.

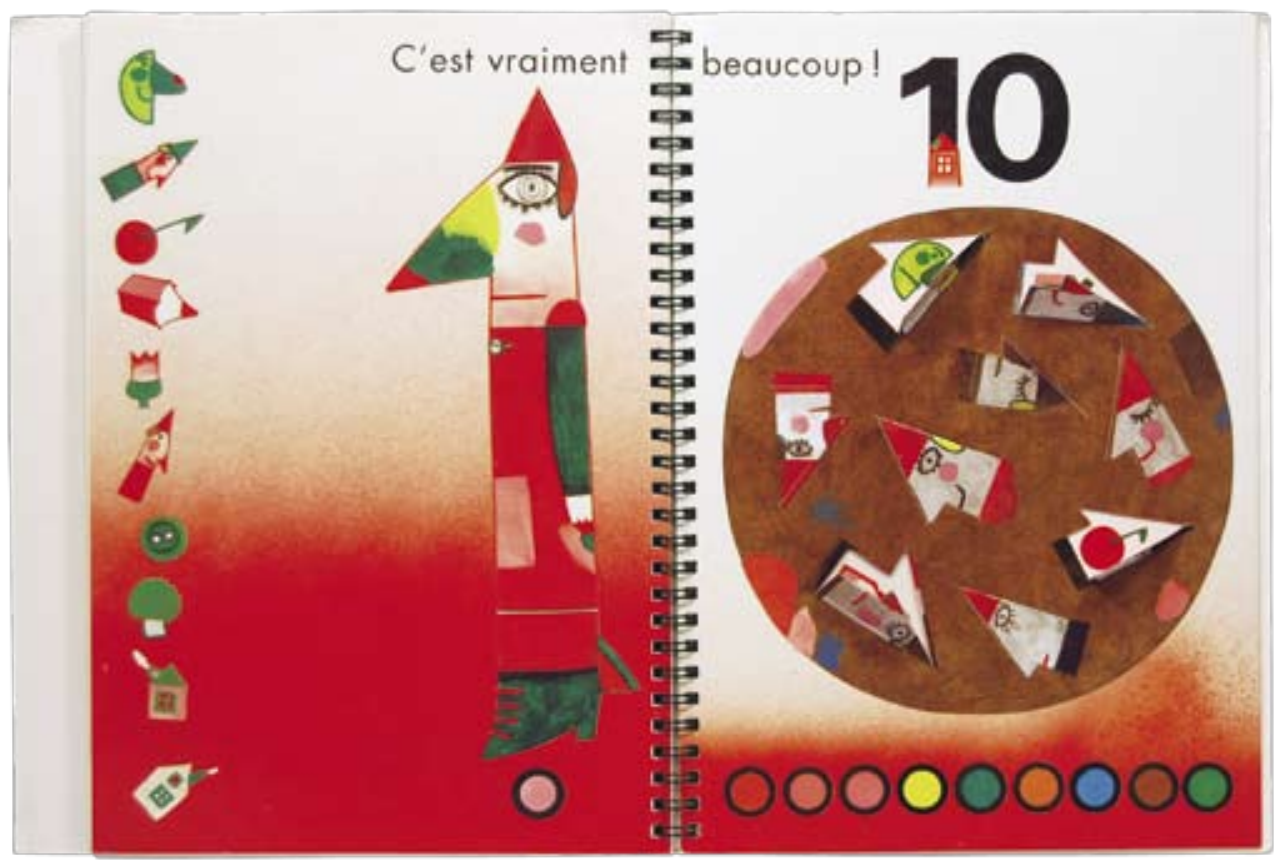




\section{PRODUÇÃO GRÁFICA}

Jamais deux sans trois é impresso em offset em quatro cores. Utiliza-se papel similar ao couché de gramatura superior a 180g, espessura suficiente para suportar as facas especiais e permitir o recorte e a dobra das janelas.

As folhas impressas nas dimensões $370 \times 270 \mathrm{~mm}$ são dobradas ao meio, recebendo impressão em ambos os lados. A autora trabalha com a impressão de folhas independentes como instrumento de projeto para viabilizar a surpresa das janelas presentes no livro.

O mecanismo lúdico das janelas brinca com a surpresa da descoberta ao abrir a aba, em que cada janela esconde uma ilustração diferenciada. As janelas são apresentadas em diversos tamanhos e sempre integradas à composição visual. Se, por um lado, as janelas estão integradas na página, por outro, as abas são tão rentes às folhas que dificultam sua abertura pelo leitor.

Outro mecanismo lúdico recorrente neste livro é o uso da faca especial, presente na criação de aberturas inusitadas. Os vazios desenhados, quando sobrepostos à página seguinte, criam uma nova percepção do desenho. Um buraco, numa folha, que permite ao leitor explorar a leitura através da abertura.

A faca especial permite ainda desenhar contornos e vazados para visualizar o interior da página dobrada. Com este mecanismo, cria-se uma textura na página, um ponto focal e um convite à leitura pelo tato. A exploração da sinestesia está presente também no uso de alto revelo em alguns elementos da página, utilizando a impressão a seco sob um desenho.

Pacovská utiliza o encarte sanfonado para criar um elemento singular. Uma sanfona quadrada de $4 \mathrm{~cm}$ apresenta a sequência numérica do 1 ao 9, inserida no centro da ilustração de uma palma de mão. Na página oposta da dupla, uma mão semelhante termina a contagem dos números e no lugar da sanfona há um papel espelhado.

A encadernação wire-o é utilizada para unir as lâminas soltas. A capa é composta por um papel cartão de gramatura superior à do miolo, impresso apenas na frente. O cartão dobrado produz a lombada quadrada para a proteção do wire-o. Na capa, a ilustração faz referência aos principais elementos que se repetem ao longo da narrativa, o hipopótamo, o homem narigudo, os números e o círculo.

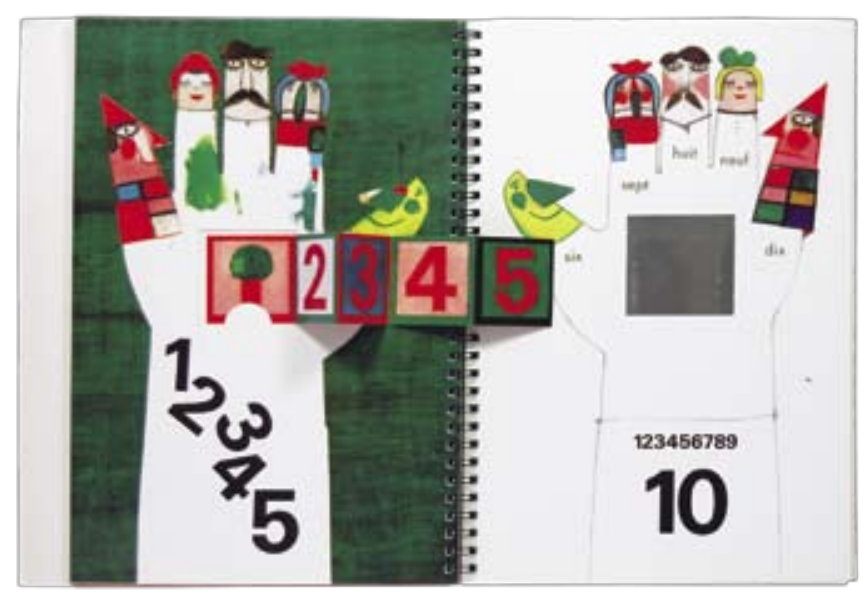




\section{MIDNIGHTPLAY}

North-South Books, 1994

$220 \times 340 \mathrm{~mm}$

capa dura costurado

offset 5 cores

impresso em Hong Kong

\section{[Mitternachtsspiel}

Michael Neugebauer Verlag, 1992]
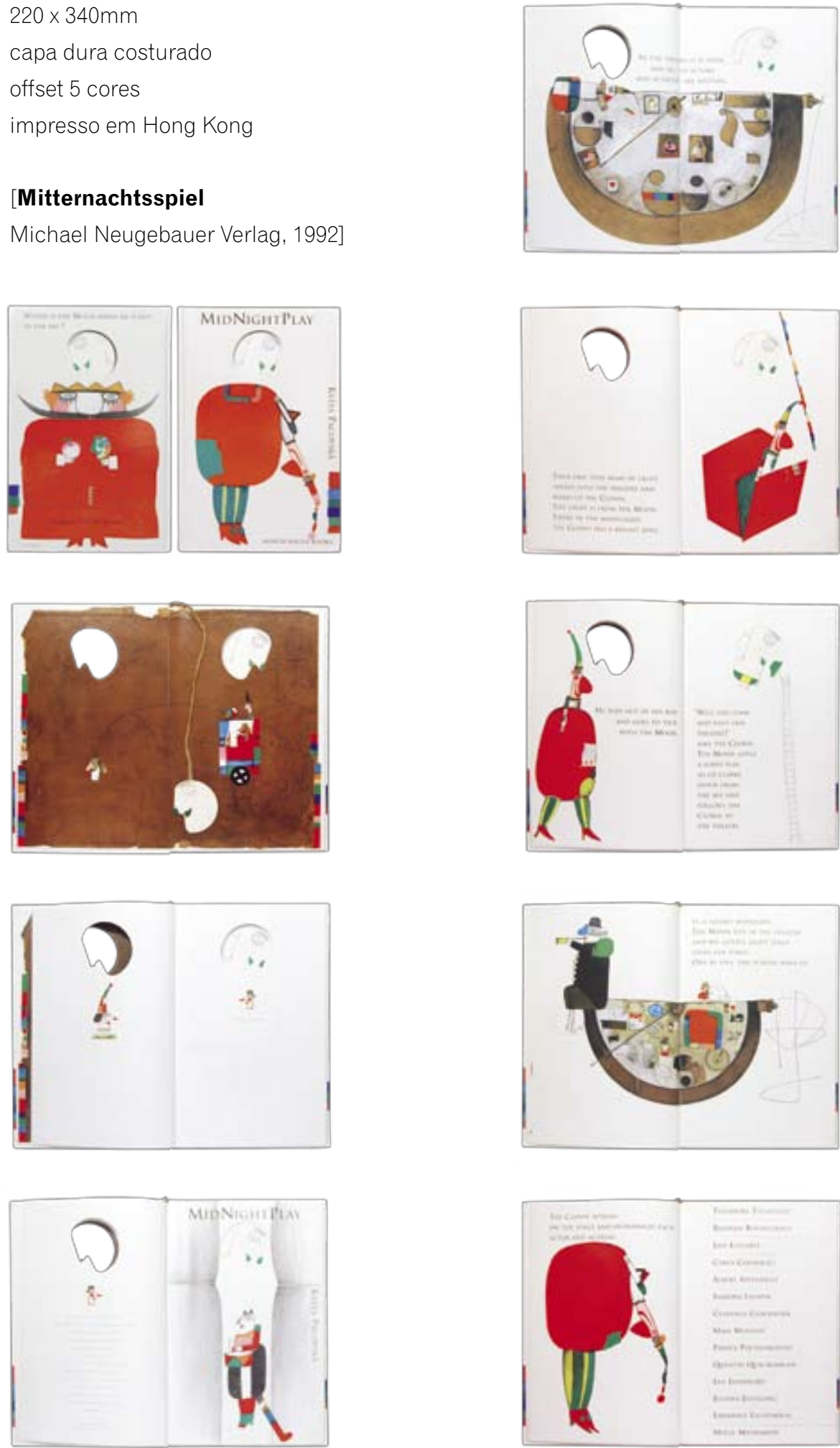

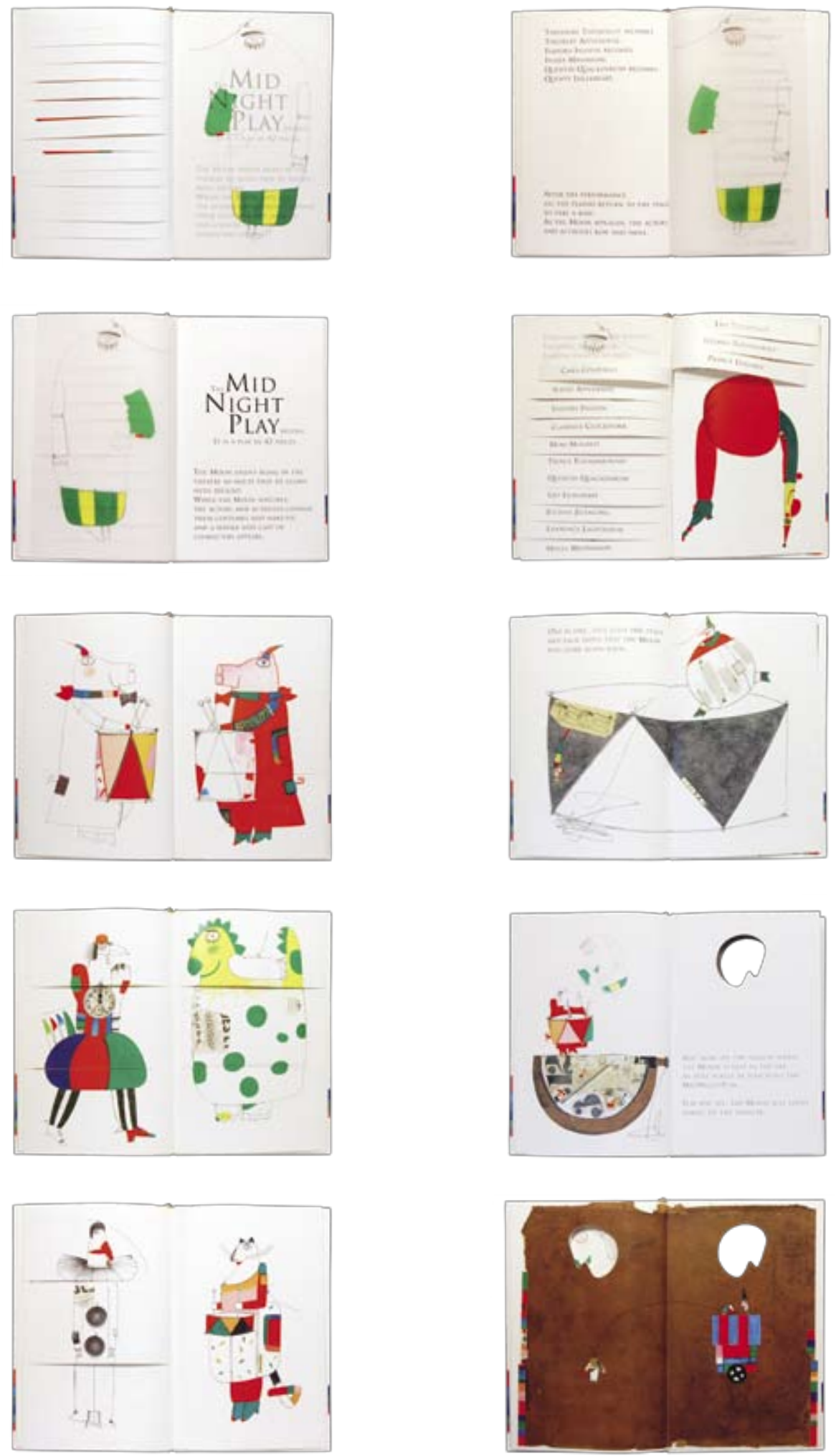
Midnightplay é um passeio visual por uma apresentação teatral. A lua atravessa a narrativa, na posição privilegiada de espectador, ocupanda a parte central superior da página, mas também presente no marcador de páginas, permitindo que o leitor carregue a lua a qualquer parte do livro.

A luz da lua ilumina as ideias de um palhaço que a convida a descer do céu e conhecer o teatro. A partir deste momento, a lua passa a tomar o mesmo ângulo de visão do leitor, um espectador do espetáculo, desaparecendo das páginas subsequentes da apresentação teatral.

Aos poucos, todos os integrantes da peça acordam e se apresentam à protagonista. Uma sequência de tiras com nomes, que, ao virar a página, apresenta os artistas simulando os cumprimentos de palco. A autora brinca com os nomes e sobrenomes estabelecendo características que tornam possível associar os personagens a seus nomes.

Uma página de papel vegetal sobrepõe o anúncio do espetáculo. Personagens e fantasias podem ser permutados por meio de um recurso de produção gráfica, a divisão das páginas em três partes, permitindo que o leitor explore as possibilidades apresentadas.

Após a interação com os personagens da peça, o texto prepara o leitor para o encerramento, as tiras de nomes fazem os cumprimentos finais de agradecimento e convidam a lua e o leitor a assistirem novamente uma apresentação. A autora explica, poeticamente, que uma das possibilidades para o fato da lua não estar presente todas as noites no céu, é a de que ela poderia estar no teatro.

Dois instrumentos lúdicos são evidentes neste livro-objeto: o jogo de imagens e o jogo com recortes. $\mathrm{O}$ jogo de imagens explora a troca de figurino, o que simula a dinâmica de apresentações durante um espetáculo. O recurso da divisão dos personagens em três partes iguais, separando cabeça, tronco e pernas, é muito explorado em livros-objeto, como por exemplo em Gente Maluca, All mixed up, Bob Gill's A to Z.

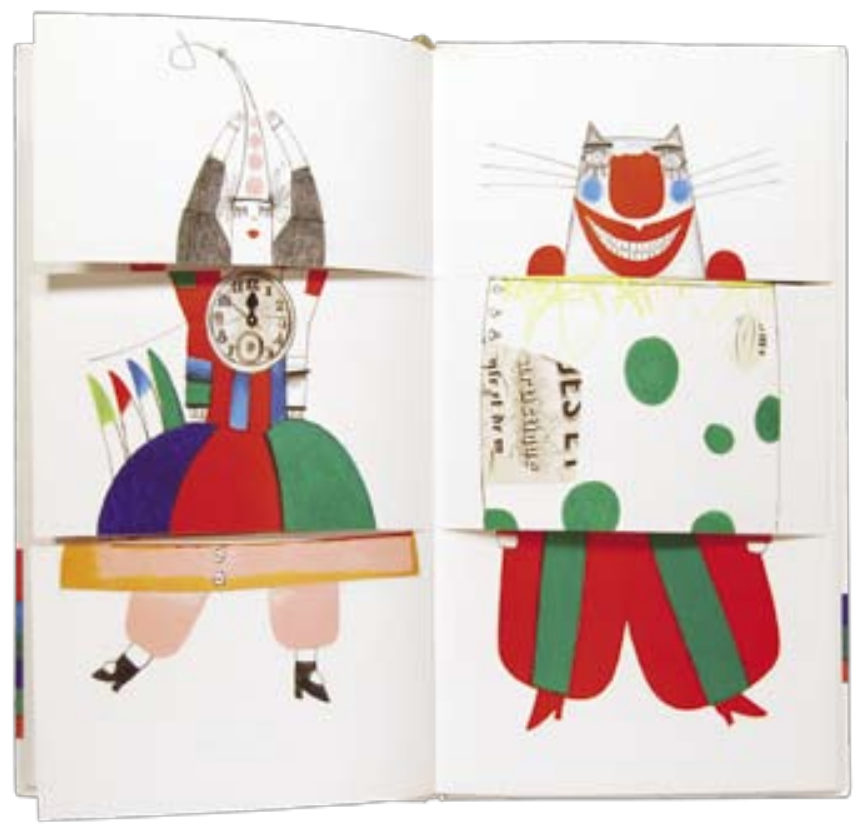



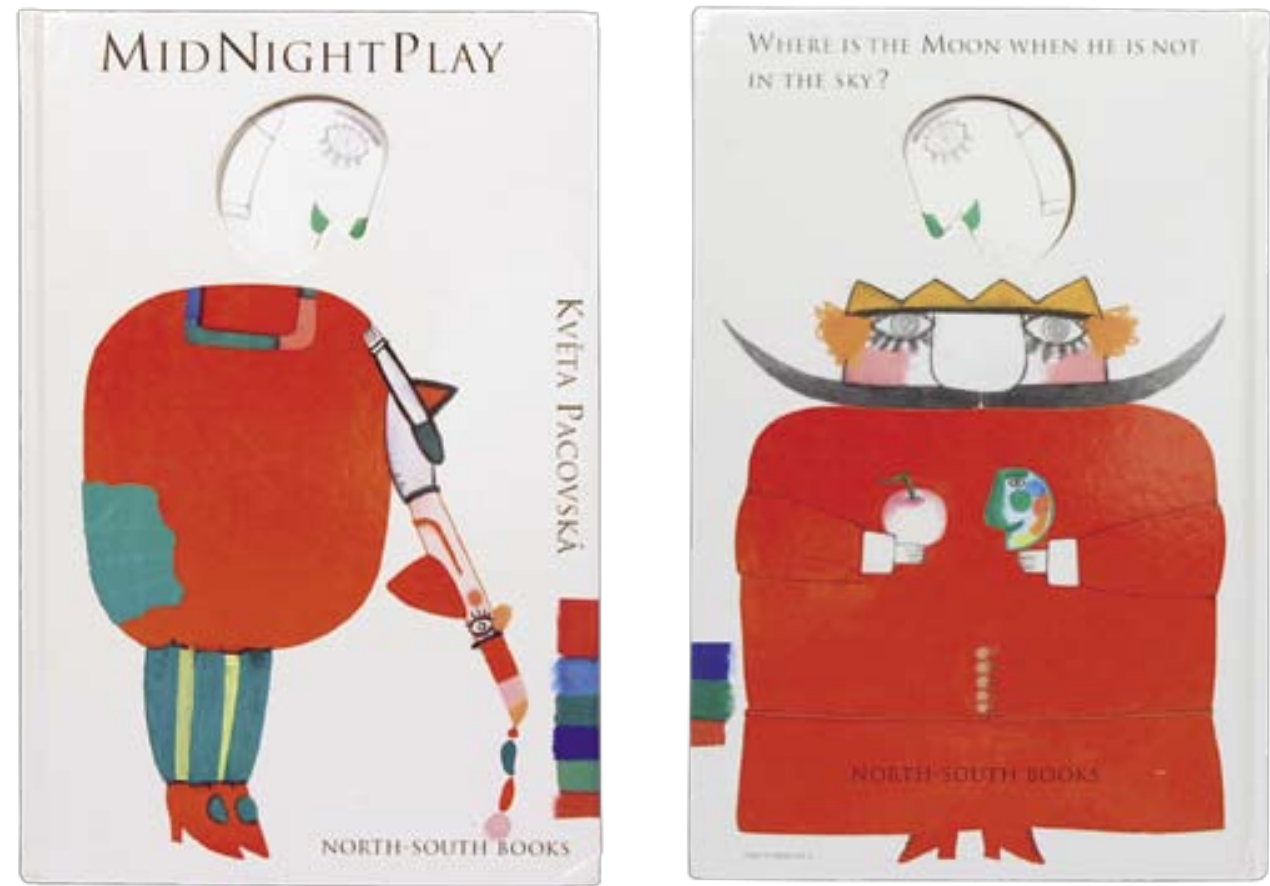

O recorte explora a percepção na caracterização da personagem lua por meio de facas especiais. Estas aparecem no vazio em formato de lua e na ilustração lida através do vazado. Outra faca especial permite manipular as tiras com nomes gerando um movimento semelhante ao cumprimento. O leitor pode virar as tiras de formas distintas, todas juntas ou uma a uma.

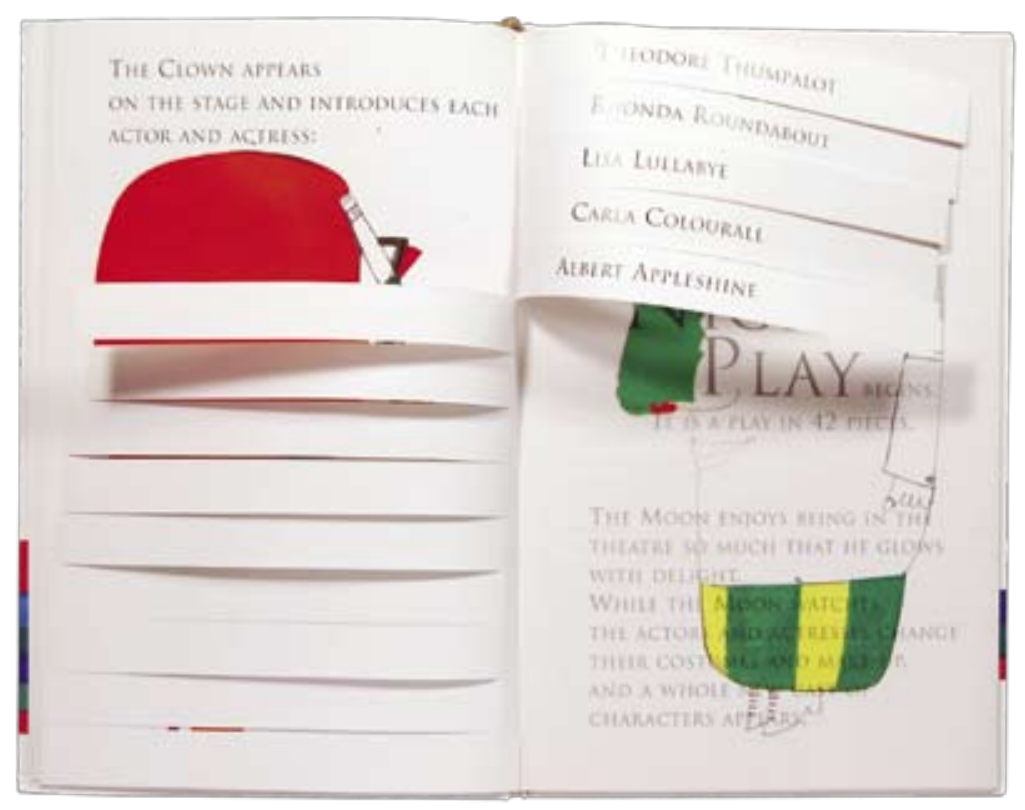




\section{FORMATO}

Midnightplay possui formato retangular, nas dimensões de $220 \times 340 \mathrm{~mm}$, a página segue a proporção racional, próxima de 1:1,538. Este formato permite que os personagens fiquem dispostos em corpo inteiro centralizado na página.

Este livro é considerado de grande dimensão se comparado à maioria dos livros infantis, mas seu tamanho facilita a manipulação do leitor. Caso contrário, o jogo com os nomes recortados não teria o efeito esperado.

O livro é composto por 44 páginas impressas, distribuídas em 5 cadernos de duas folhas. As páginas impressas em vegetal são coladas ao couché fosco, na parte interna dos cadernos. Se tomar a página dupla impressa, obtém-se as dimensões 440 × 340mm, concluindo-se que o aproveitamento de papel não foi levado em conta na produção deste livro-objeto.

\section{TIPOGRAFIA}

O exemplar analisado é uma versão traduzida para o inglês, não se pode afirmar que a tipografia aplicada na primeira versão foi mantida nesta. Na tradução sempre é possível uma adaptação ou a substituição da fonte, por isso a análise levará em conta a tipografia presente.

Utiliza-se uma fonte com serifa triangular fina e versalate, da família Trajan. O corpo equivale, aproximadamente, a 25 pontos e a entrelinha a 40 pontos. Pela característica da narrativa, reduzida massa de texto e predomínio das imagens, o texto encontra-se distribuído no máximo em três frases por página, sem separação de parágrafos. $\mathrm{O}$ alinhamento dos parágrafos é quase sempre à esquerda.

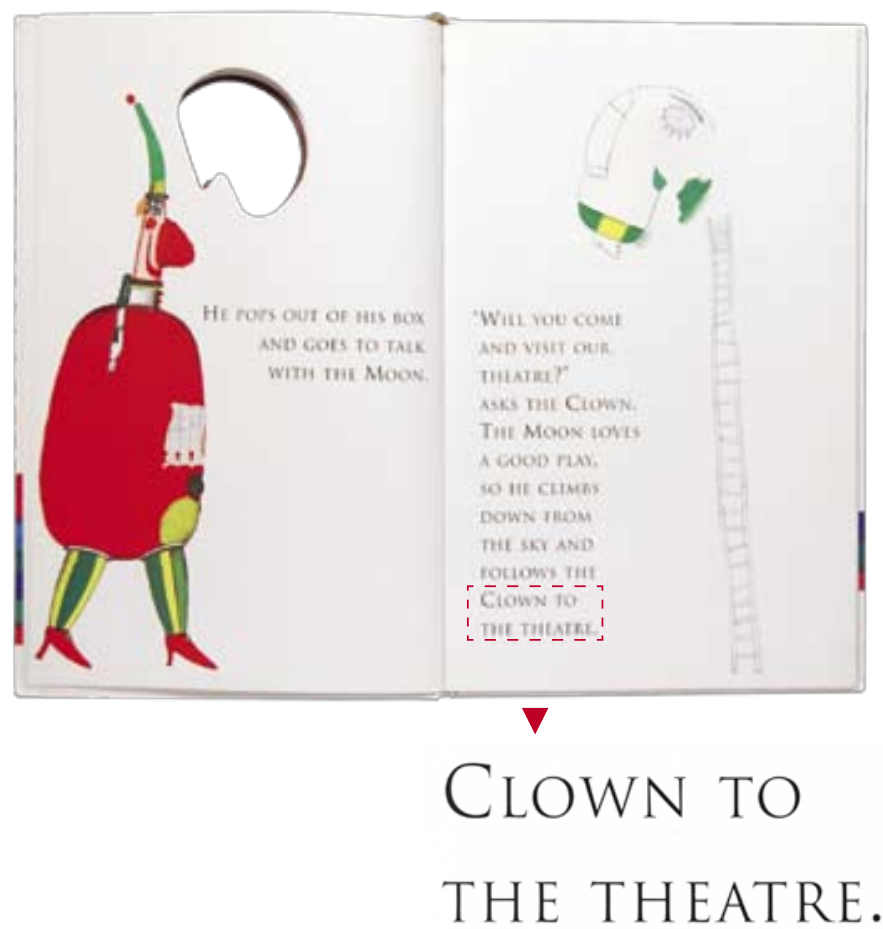


O uso de um corpo tipográfico grande deve estar associado à relação entre a dimensão da página e a quantidade de texto. Um corpo pequeno exige uma massa de texto maior para que a composição visual funcione. Conclui-se que o tamanho aplicado nos tipos é adequado à proposta do livro, sua dimensão não prejudica a legibilidade.

O texto obedece ao projeto tipográfico descrito, e somente uma página destoa do restante. Esta recebe destaque nas palavras "Mid Night Play" com o aumento do corpo e alinhamento diferenciado, insinuando que se tratar de um cartaz da peça narrada.

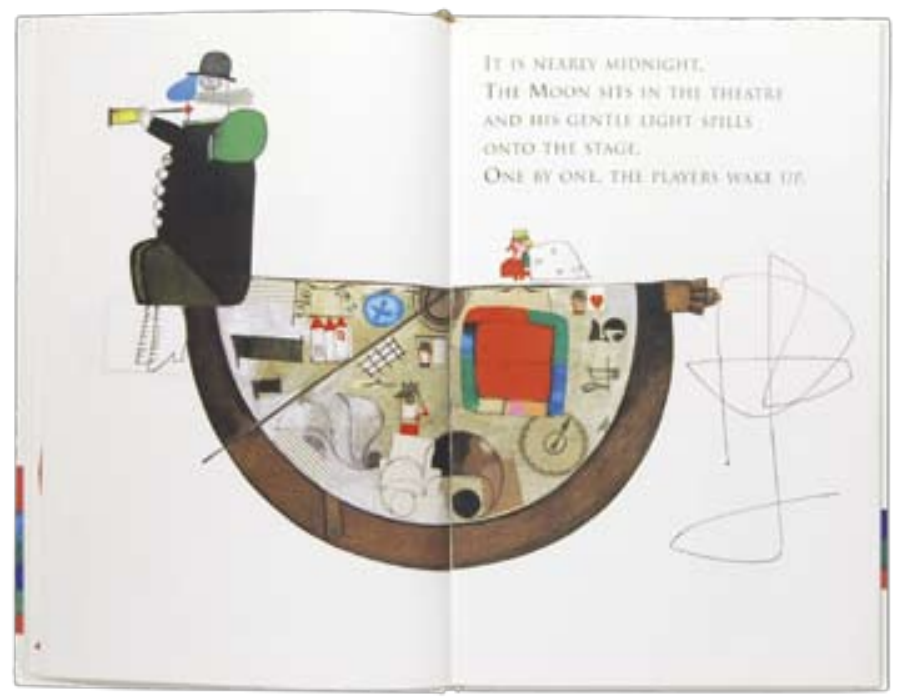

\section{ORGANIZAÇÃO DA PÁGINA}

A diagramação é orientada pelo uso da imagem, enquanto esta predomina na parte superior, o texto distribui-se na parte inferior. O preenchimento da página é contrabalanceado pelas cores das ilustrações.

O texto está estruturado dentro de uma malha, em que a altura obedece à entrelinha e à largura, intrinsecamente ligada ao uso da imagem. O equilíbrio entre texto e imagem centra-se na dobra da página, que funciona como um espelho, refletindo massas de mesma proporção visual.

As imagens estão dispostas sem uma grelha visível. Contudo, as ilustrações respeitam as seguintes regras comuns: margem externa de $20 \mathrm{~mm}$ e, quando possível, centralizada horizontalmente na página.

\section{LINGUAGEM VISUAL DAS ILUSTRAÇÕES}

Pacovská trabalha com o predomínio de cores fortes e vibrantes, principalmente das cores elementares, azul, vermelho e verde. As cores quentes sobressaem na composição cromática. As ilustrações deste livro-objeto não fogem da linguagem gráfica desenvolvida pela artista ao longo da sua trajetória, em suas obras aplica técnicas mistas de desenho, com predomínio da colagem e pintura. 


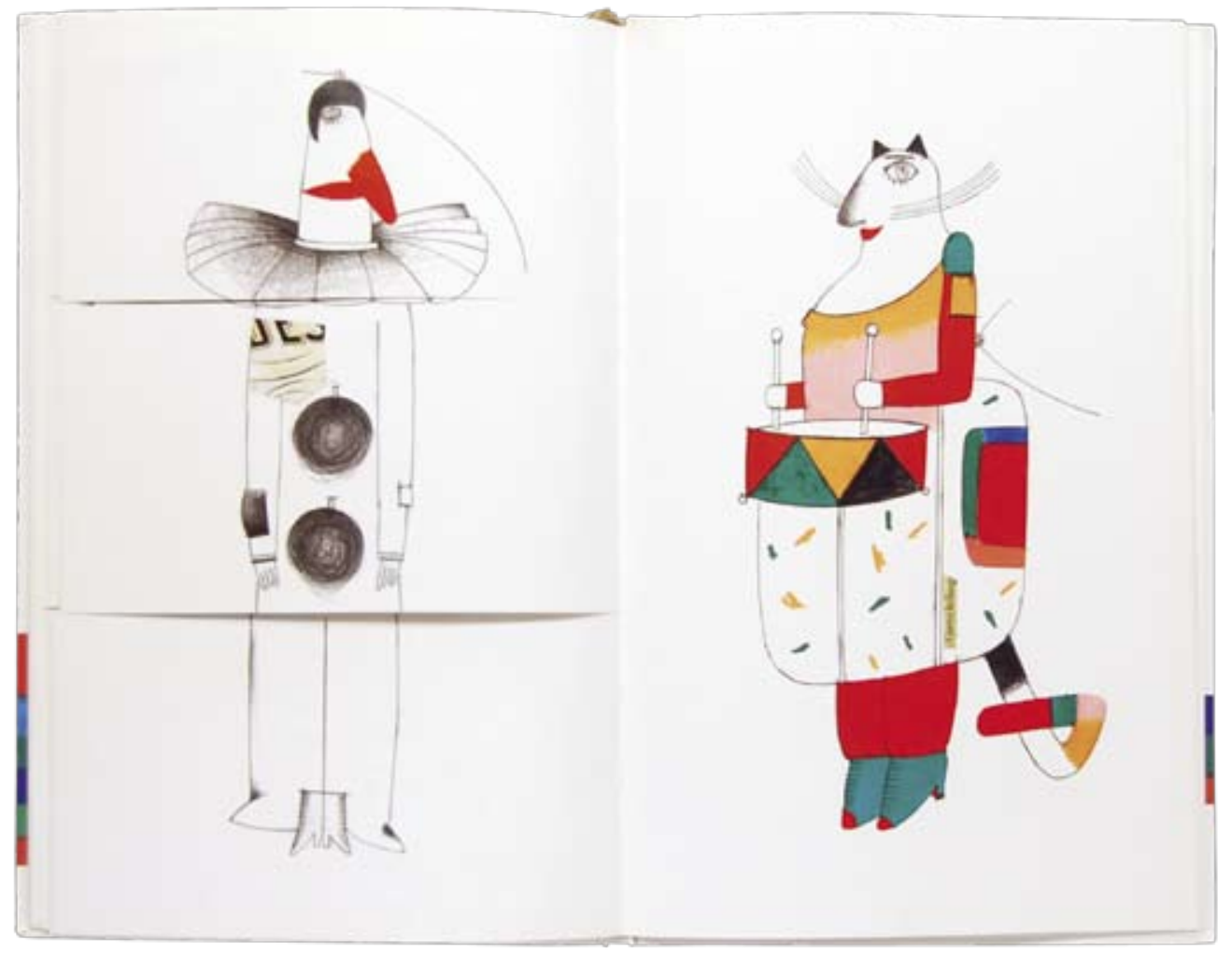

A autora trabalha com a técnica da colagem, não apenas para montar os personagens, mas também para integrá-los aos elementos de fundo. Ao se observar uma páginadupla, percebe-se que a diagramação dos elementos é obtida por meio da colagem. Os elementos são adicionados e sobrepostos sem esconder a marca do recorte. Alguns elementos são retomados ao longo das imagens: a última página do livro, por exemplo, traz uma montagem de elementos que já apareceram anteriormente.

Os personagens formados pelos elementos geométricos, quadrados e círculos, não respeitam as proporções reais do corpo, obtendo figuras inusitadas e bem humoradas. Os protagonistas apresentam características e comportamentos de seres humanos, como o uso de roupas, apesar de nem todos os serem.

Nas ilustrações, a profundidade é implícita, apesar do uso de cores chapadas, pois a perspectiva é criada por meio do desenho. O desenho esboçado a lápis por vezes é encoberto pela tinta, eliminando o contorno. Não há recursos de sombra e luz nas páginas, o que resulta em desenhos graficamente mais limpos.

As imagens fortes contrapõem o branco do fundo, este respiro da ilustração permite que o leitor não canse o olhar, equilibrando a composição cromática. Apesar de a composição ser limpa, as imagens são carregadas de pequenos detalhes simbólicos, que amparam a narrativa com informações relevantes sobre espaço e tempo. 


\section{PRODUÇÃO GRÁFICA}

Midnightplay é um livro impresso em processo offset em cinco cores, sendo a quinta um vermelho especial, o que gera ilustrações mais vibrantes. Este recurso aparece em quase todos os livros de Pacovská, o predomínio do vermelho é uma marca registrada de suas obras.

O miolo é composto de papel similar ao couché fosco de gramatura 150g. A escolha do papel couché permitiu o jogo dos cumprimentos dos artistas e a brincadeira com a troca das personagens e suas respectivas funções. Um papel de maior gramatura não permitiria a flexibilidade de manipulação, da mesma forma que um de menor gramatura amassaria durante o manuseio.

Este livro faz uso de algumas facas especiais. A primeira aparece na capa e quarta capa, e se repete nas primeiras e últimas páginas do livro. O recorte na forma da protagonista lua participa da narrativa como uma ilustração. O marcador de páginas, com o mesmo formato de lua, aproveita-se da faca do miolo para fornecer mais um elemento lúdico e manipulável ao leitor.

A outra faca utilizada no miolo é caracterizada por repetidos cortes paralelos, o que fornece o efeito dos cumprimentos ao espectador. À medida em que se inicia o movimento de virar as páginas, as tiras de nomes curvam-se automaticamente. Este efeito apóia-se, também, no formato da página. A proporção das tiras em contrapartida com a dimensão da página permite que se obtenha o virar de cada tira numa sequência rítmica.

A terceira faca é utilizada para repartir cabeça, tronco e pernas, permitindo que o leitor brinque com as permutações dos personagens. Esta é fundamental para a estrutura do jogo proposto, e representa o tempo da narrativa no palco. A mudança representa, simbolicamente, as trocas de cenário e de números dentro de uma peça teatral, criando a analogia ao espetáculo.

A capa dura, papelão empastado e laminado, viabiliza o corte especial nas capas, de forma a assegurar a rigidez necessária. O miolo costurado e colado fornece durabilidade.

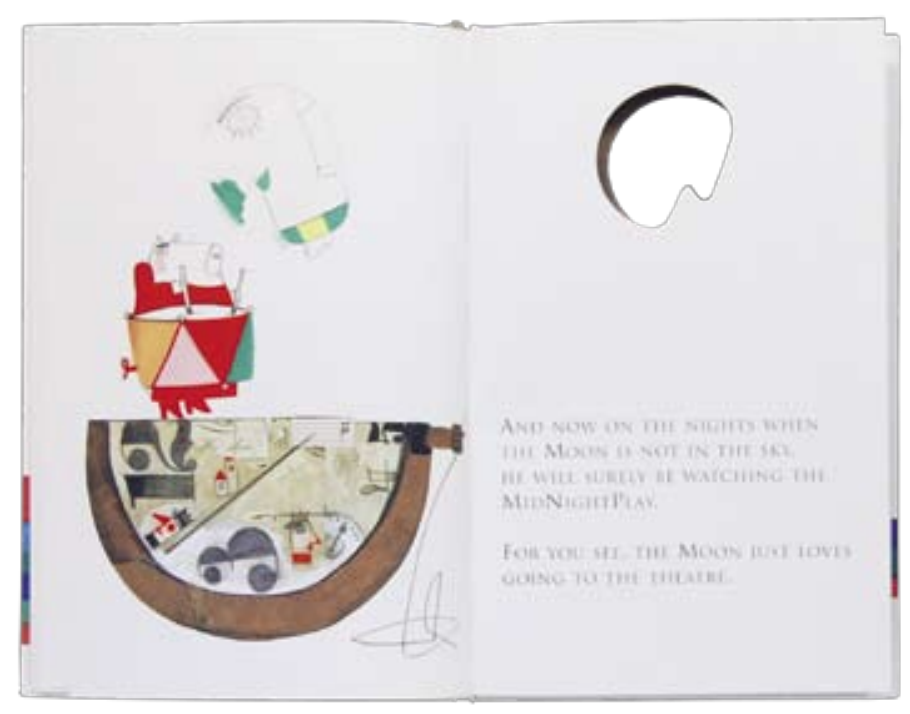




\section{BRUNO MUNARI}

Munari (1907-1998), um italiano reconhecido internacionalmente como pintor, escultor, fotógrafo e designer gráfico, publicou inúmeros livros que vão desde a teoria da comunicação visual aos infantis, projetou objetos, brinquedos e jogos. Munari atuou em diversos campos artísticos estendendo sua pesquisa aos temas do movimento e da luz, bem como ao do desenvolvimento da criatividade e da fantasia na infância por meio do jogo.

No início de sua carreira, seguiu o movimento futurista, apresentando seu trabalho em diversas exposições. Após a Segunda Guerra Mundial, passou a se dedicar ao desenho industrial. Neste momento começou a projetar livros-objeto.

Entre os inúmeros prêmios que recebeu se destacam: Prêmio Andersen (1974), como melhor autor infantil; Graphic na Feira de Bologna (1984); Lego (1986); Award da Accademia dei Lincei (1988); Prêmio Spiel Gut de Ulm; ADCi Milão Hall of Fame (1990); Cavaliere di Gran Croce (1994).

Munari estabelece inovações no design do livro infantil, cria instrumentos que provocam o leitor a olhar o livro sob uma nova perspectiva visual, livros-objeto que estimulam das crianças aos adultos. Entre os 63 livros publicados, destacam-se os infantis:

Le macchine di Munari. Verlag Giulio, 1942.

Mai contenti. Mondadori, 1945.

L'uomo Del camion. Mondadori, 1945

Toc toc. Modadori, 1945.

II prestigiatore verde. Mondatori, 1945

Storia di tre uccellini. Mondadori, 1945

I/ ventitore di animali. Mondadori, 1945.

Gigi cerca il suo berretto. Mondadori, 1945.

Che cos'è il termômetro. Piccoli, 1947.

Che cos'è il orologio. Piccoli, 1947.

Libro illeggibile. Jong\&Co, 1953.

Nella notte buia. Muggiani, 1956.

Le forchette di Munari. La Giostra, 1958.

Bruno Munari's ABC. The World Publishing Company, 1960.

I/ quadrato. Scheiwiller, 1960.

Bruno Munari's Zoo. The World Publishing Company, 1963.

I/ cerchio. Scheiwiller, 1964.

L'idea è nel filo. Bassetti, 1964.

Libri illeggibile. Isetan, 1965.

Libro illeggibile trasparente. Galleria del Obelisco, 1965.

Nella nebbia di Milano. Emme Ed, 1968.

Un fiori com amore. Emme Edizioni, 1968.

Da Iontano era un'isola. G. Einaudi, 1971.

Cappuccetto verde. G. Einaudi, 1972. 

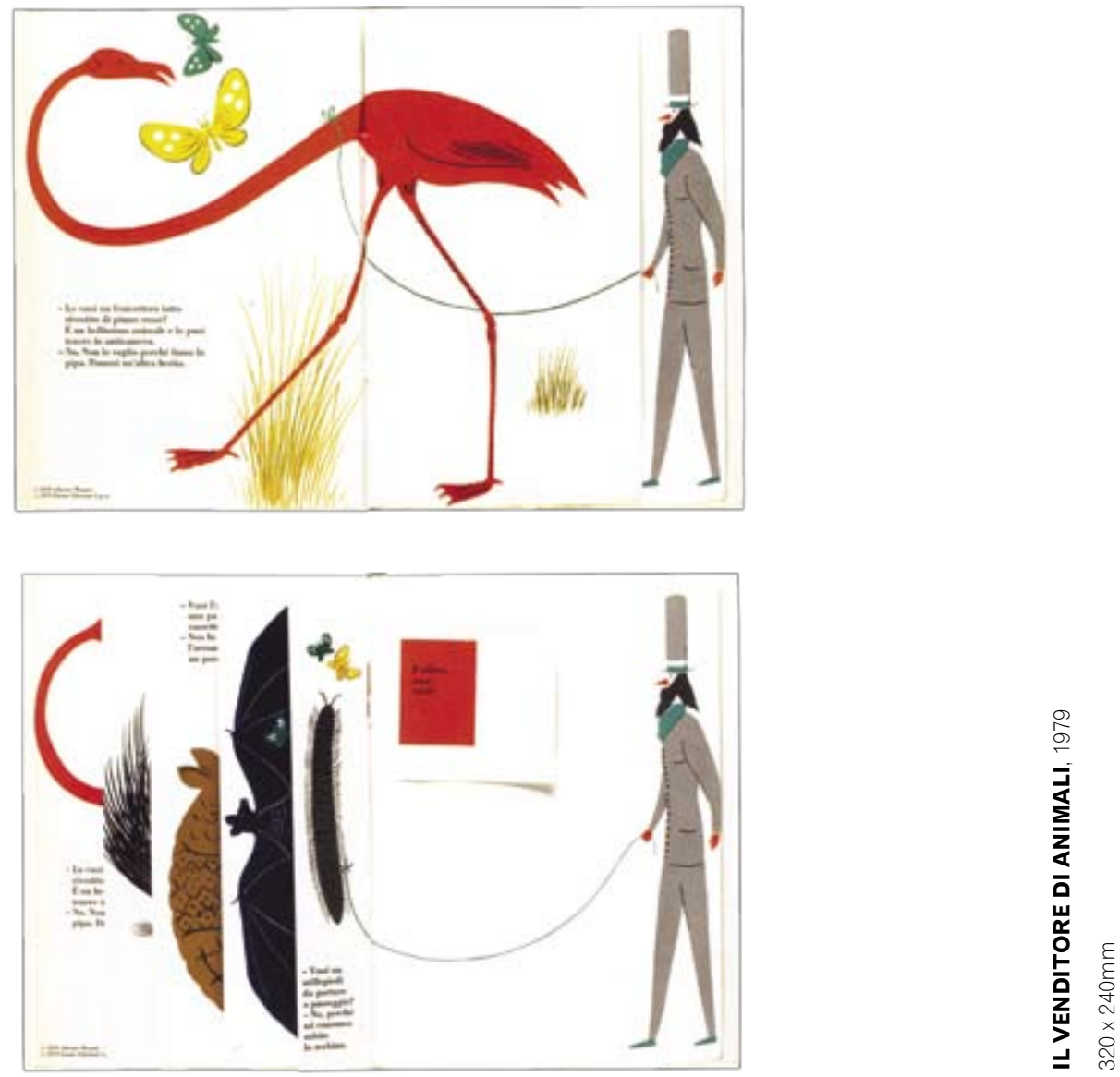

Cappuccetto giallo. G. Einaudi, 1972.

La scoperta del triangolo. Zanichelli, 1976.

Prelibri. Edizioni Danese, 1979.

MN1 Libro illeggibile. Ed Corraini, 1984.

MN2 Libro illeggibile. Ed. Corraini, 1988.

No livro infantil, Munari trabalha com uma linguagem o mais universal possível, considerando como questão prioritária a clareza e a simplicidade da informação. Uma mensagem exata representada por uma linguagem gráfica limpa, de que retira todo o supérfluo para melhor entendimento do leitor.

A escolha dos livros para a análise baseou-se nos seguintes critérios: ser um livroobjeto, apresentar narrativas visuais inovadoras e ser um objeto instigante de manipular. Todos os livros analisados foram impressos na Itália, sob a supervisão da mesma casa editorial, e por isso possuem uma cuidadosa produção e, acabamentos diferenciados que propiciam o lúdico. 
NA NOITE ESCURA

Cosac Naify, 2007

$160 \times 230 \mathrm{~mm}$

capa dura costurado

offset e serigrafia

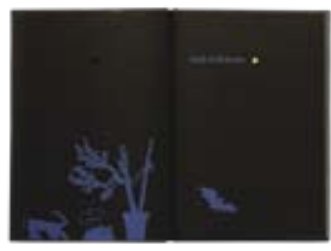

impresso na Itália

[Nella notte buia

Muggiani, 1956]
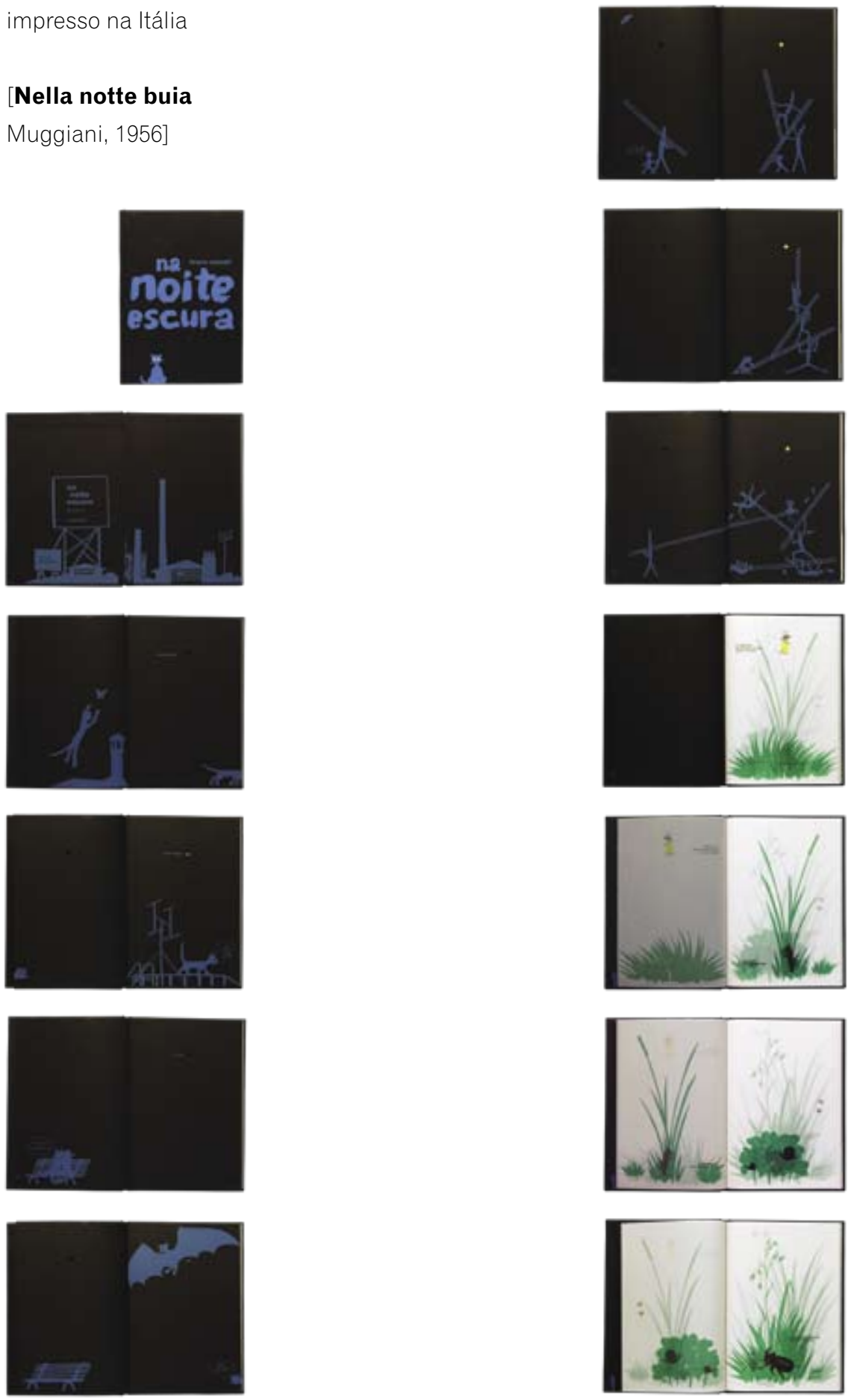

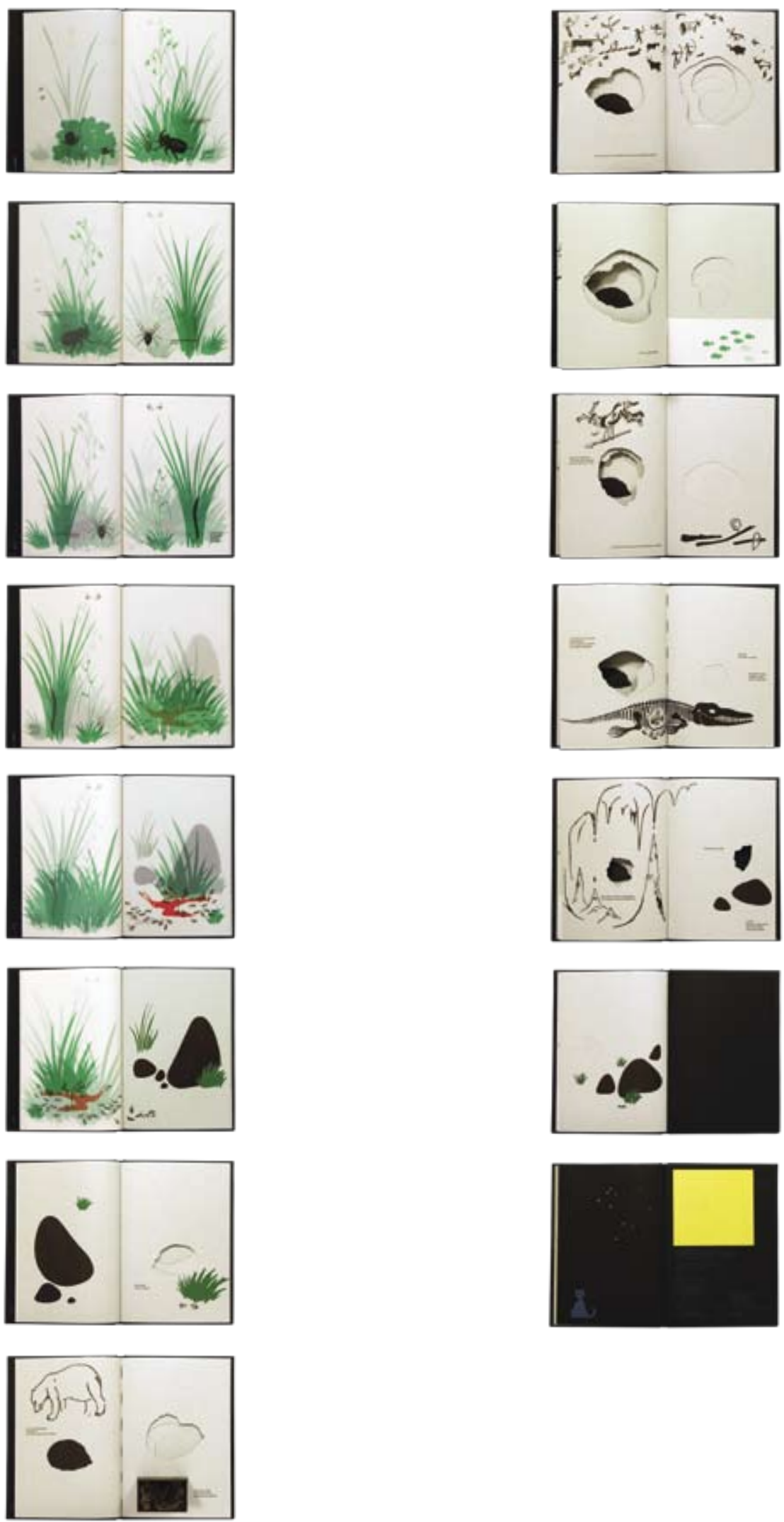


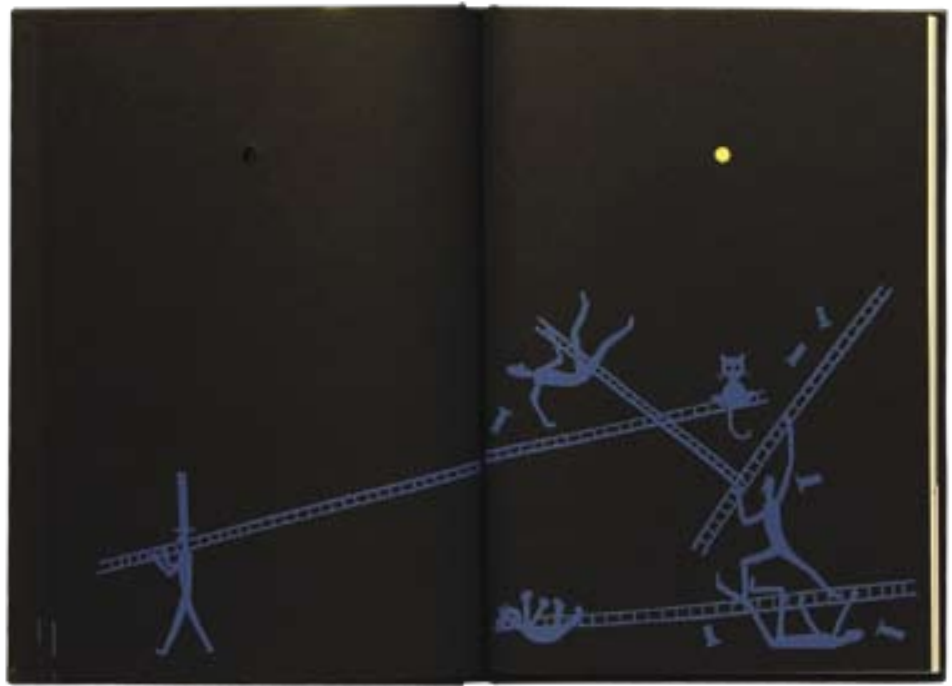

Na noite escura é uma narrativa visual em que o leitor é convidado a passear junto com os personagens num mundo de descobertas pela noite escura, pela gruta misteriosa e pelo dia no mato, cada qual representado com a impressão em diferentes papéis.

A ilustração de um gato e um texto chamam a atenção do leitor para um ponto luminoso na noite escura. Este ponto é representado com um vazado que transpassa várias folhas, permitindo que o amarelo ilumine a sequência de folhas pretas impressas em serigrafia azul. A tensão narrativa aumenta até a descoberta do vaga-lume, ponto em que o leitor é novamente convidado a explorar o mato durante o dia.

Os papéis vegetais fornecem profundidade à paisagem, devido à transparência do material. O mato é visto pelo leitor em meio às folhagens verdes e aos animais que lá habitam.

O leitor é levado a um buraco preto e convidado a entrar. Nesta passagem, o jogo de buracos de diferentes formatos é posicionado de forma a estimular o leitor a explorar as páginas por meio de uma trilha de aberturas. Ao fim, o leitor depara-se novamente com a noite e seus vários pontos luminosos.

Este livro de capa dura nasceu da experiência de Munari com os Livros-ilegíveis, nos quais as imagens abstratas transformam-se ao virar da página. O autor explora o jogo de recortes por meio de diferentes papéis e alguns cortes especiais, o que permite brincar com o contraste e a opacidade através dos materiais.

A capa e as guardas utilizam a mesma linguagem e material do início do livro. A imagem de um gato azul, com os olhos de vaga-lume num fundo preto, associada ao título enigmático, estimula a curiosidade do leitor para abrir o livro.

\section{FORMATO}

Na noite escura é produzido no formato retrato, seguindo nas dimensões $160 \mathrm{x}$ $230 \mathrm{~mm}$, uma proporção racional aproximada de 1:1,4. Esta proporção, se considerada uma folha BB, $960 \times 660 \mathrm{~mm}$, produzirá 8 folhas com reduzida perda de material. 


\section{TIPOGRAFIA}

A edição aqui analisada é uma versão traduzida do italiano para o português, portanto a avaliação apresentada restringe-se a este volume. A tipografia usada na massa predominante de texto é a Helvetica bold. Os balões de diálogo utilizam uma letra cursiva, a fim de diferenciar as duas vozes: a do narrador e a dos personagens.

O corpo das fontes varia de 9 pontos a 23 pontos. Esta variação fornece ritmo à narração, expressando distância ou proximidade com o objeto observado, e demonstrando sentimentos, através da sugestão de diferentes entonações, uma vez que a pontuação não está presente.

A narrativa dá-se por pequenas frases, sem divisão de parágrafos, compostos no máximo por 4 linhas. As pequenas caixas de texto são compostas por helvética bold de corpo de 8 pontos e entrelinha de 11 pontos. A mancha tipográfica é homogênea e composta toda em caixa baixa.

Na capa a tipografia é desenhada com pincel, expressando a gestualidade do artista. A versão analisada aproveita parte da grafia original de Munari e recria, no mesmo estilo, as letras faltantes.
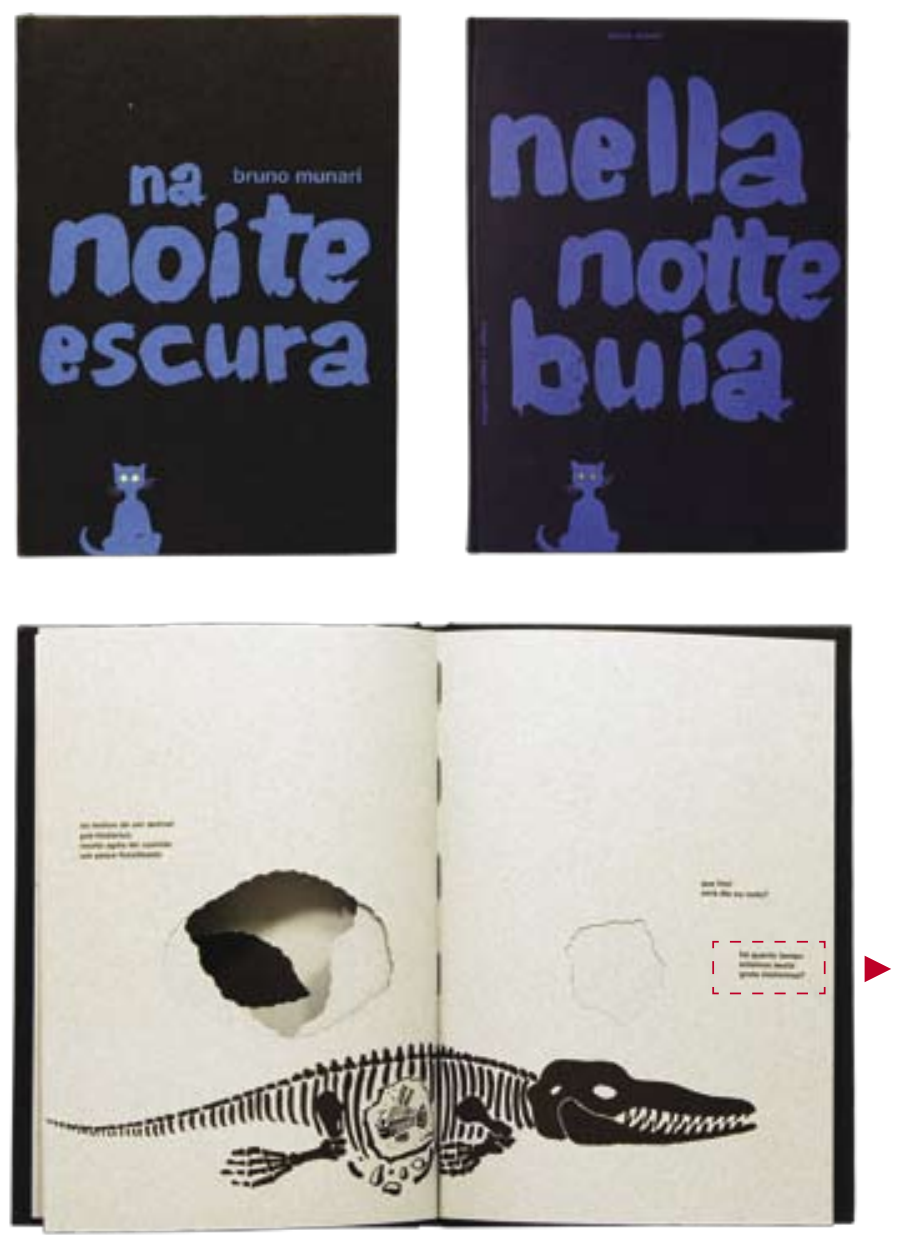

há quanto tempo

estamos nesta gruta misteriosa? 


\section{ORGANIZAÇÃO DA PÁGINA}

O texto se organiza em função da imagem na página, que obedece a diferentes estruturas. O ponto luminoso, buraco que transparece o amarelo, é a referência de alinhamento para as palavras num primeiro momento.

O texto no vegetal está inserido numa malha estruturada em 8 colunas e 50 linhas, mas as caixas de texto não ultrapassam 3 colunas e 4 linhas. Estas nunca são alinhadas na mesma coluna, evitando assim que os blocos apareçam sobrepostos, pela transparência do material, o que prejudicaria a legibilidade. O texto em preto é impresso sobre uma grande massa verde, neste momento imagem e texto se fundem no mesmo espaço da página.

Nas páginas do papel texturizado, a malha é contínua e estabelecida em 8 colunas, mas com as margens laterais mais largas, gerando uma nova guia, numa nítida separação de imagem e texto. Os buracos no formato de caverna, além de participarem como desenho, servem de divisão do campo visual, separando a página em três blocos ilustrados.

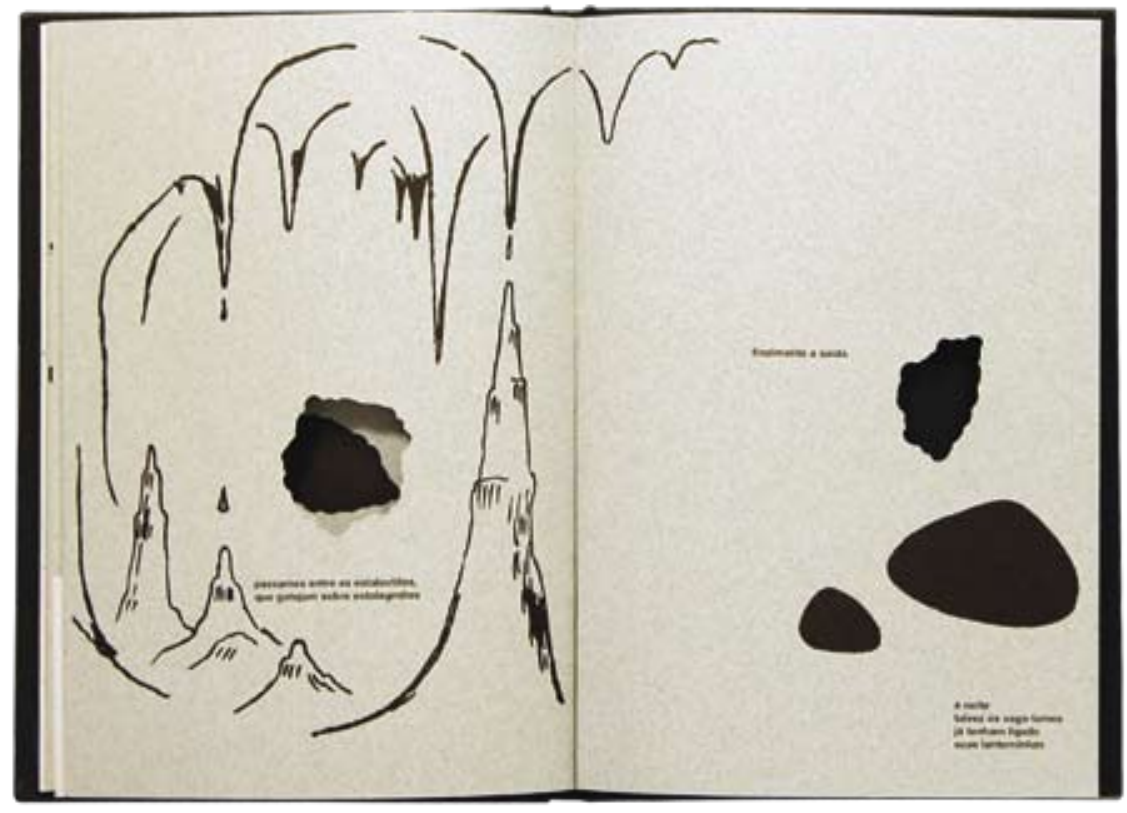

O alinhamento do texto é, predominantemente, à esquerda. No entanto, há algumas exceções, principalmente na parte correspondente à caverna, em que o texto aparece alinhado à direita na maioria das páginas. As palavras estão concentradas do centro para baixo na folha.

No transcorrer da narrativa, a mancha textual prevalece pequena e pontual, o que a contrapõe à forte presença da ilustração. O texto assume papel secundário na narrativa, funcionando, em muitos casos, como legenda ou indagação da imagem exposta. As imagens preenchem grande parte do campo, distribuindo-se nas margens inferiores e superiores. 


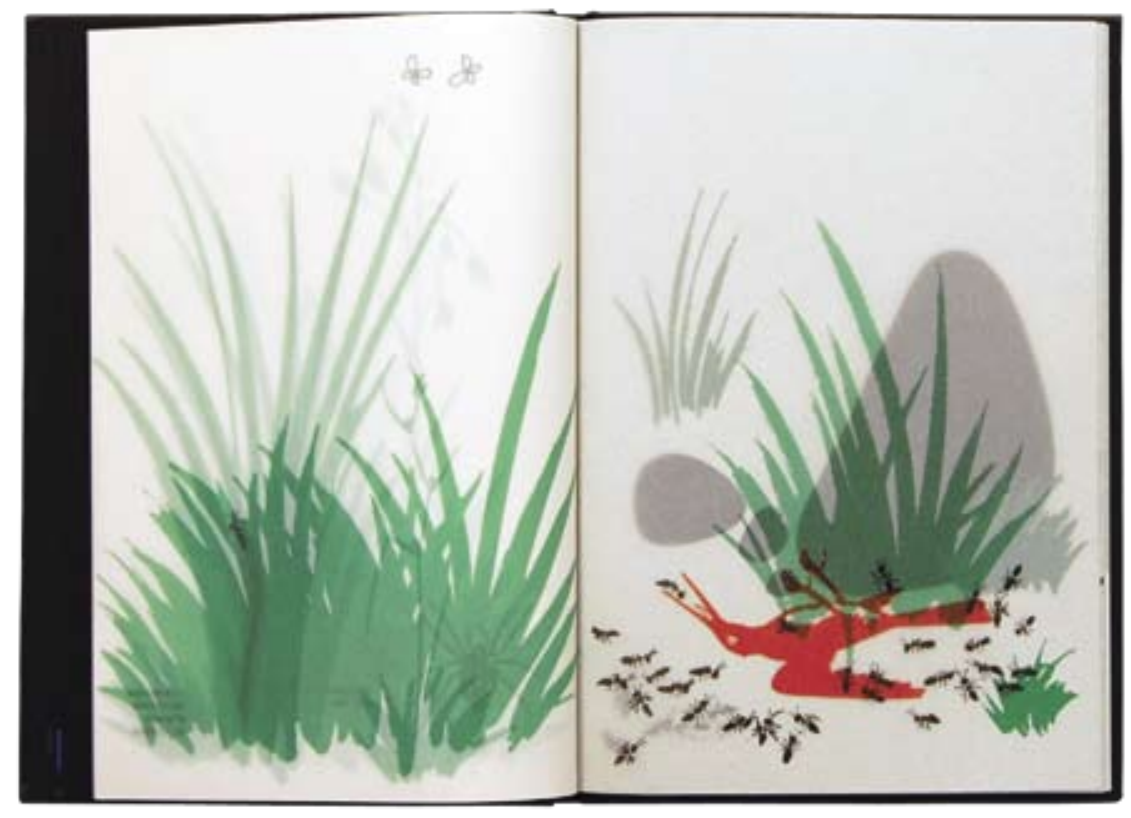

\section{LINGUAGEM VISUAL DAS ILUSTRAÇÕES}

Munari trabalha, neste livro, com desenhos mais próximos de símbolos pictográficos, ilustrações chapadas em uma única cor, sem a presença de contornos. As imagens são limpas, quase sem detalhes, numa linguagem extremamente sintética, o que proporciona uma leitura rápida.

Apesar de as imagens serem ilustrações chapadas, a profundidade é estabelecida pelo contraste do vegetal, bem como pelos cheios e vazios dos buracos recortados. $\mathrm{O}$ uso das cores permite uma percepção do espaço e tempo representados.

Na primeira parte da narrativa, durante a noite, o preto do papel sobressai na página diagramada. O azul escuro das ilustrações funde-se com o tom do fundo, cabendo ao ponto amarelo o destaque visual. Apenas estas três cores aparecem neste momento, associando ao azul dos personagens a penumbra da noite, ao amarelo a luminosidade dos vaga-lumes, e ao preto a escuridão.

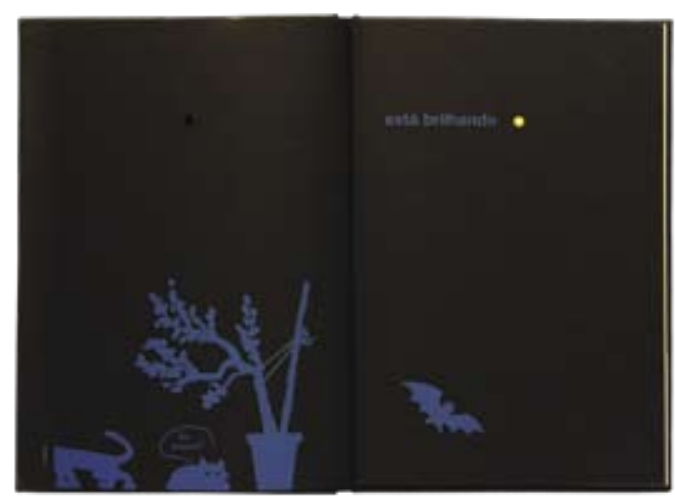




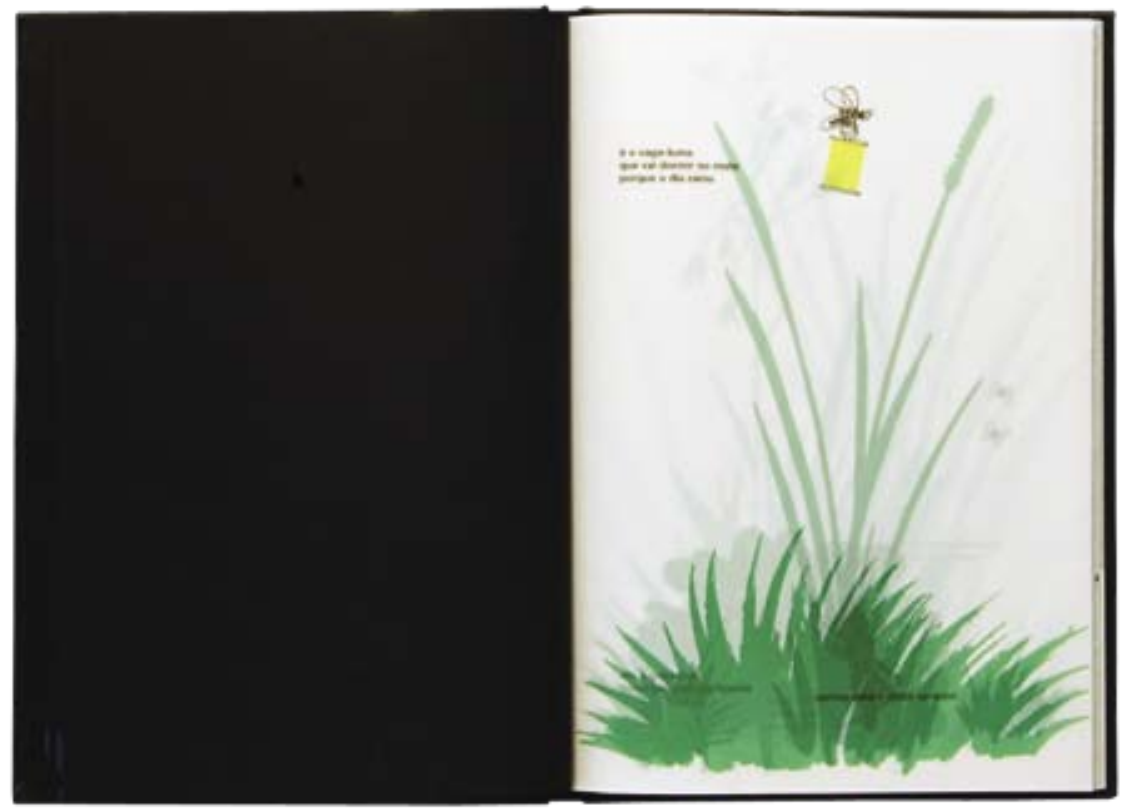

Num segundo momento, o vegetal representa a claridade do dia, contrapondo-se o preto da noite. A luminosidade é percebida pela transparência do papel, que também fornece profundidade à sequência visual. Munari desenha uma série de plantas, que, quando sobrepostas, progressivamente desaparecem.

Os vegetais são impressos apenas de um lado, de forma que a sobreposição não fique carregada de informações. No percorrer das folhas, gafanhoto, borboleta, caracóis, escaravelho, aranha, centopéia, e formigas são ilustradas em preto, contrastando-se ao verde da folhagem. A narrativa culmina na morte de um pássaro, marcada pela cor marrom.

Na última parte do livro, associam-se a textura do papel e o tom cinza ao interior de uma caverna. O desenho de uma grande pedra preta esconde a entrada da caverna, algumas folhas de grama verde-escuro aparecem na entrada e saída da caverna, mas todo seu percurso é marcado pelo preto das ilustrações, simbolizando a ausência de luz.

O desenho formado pela sobreposição dos buracos predomina na página diagramada. As ilustrações deste trecho se diferem das anteriores, ganham leveza por meio da redução no tamanho e pelos desenhos sem preenchimento. Assim, a ilustração e os buracos equilibram-se visualmente.

\section{PRODUÇÃO GRÁFICA}

Na noite escura se beneficia de diversos recursos de produção gráfica, a impressão em serigrafia, mistura de substratos diferentes, facas especiais e inserção de encarte. Apesar de se utilizar de instrumentos lúdicos, apresenta solução simples de projeto, sendo possível sua realização pela indústria gráfica da década de 1950.

Este livro utiliza três papéis diferentes na sua composição: preto, vegetal e texturizado, similares ao colorplus preto de gramatura $240 \mathrm{~g}$, ao vegetal de gramatura $112 \mathrm{~g} \mathrm{e}$ 
Marakech de gramatura $180 \mathrm{~g}$. Devido às elevadas gramaturas e à sequência narrativa, os cadernos costurados são compostos de 2 ou 3 folhas nas dimensões $320 \times 230 \mathrm{~mm}$.

A impressão em serigrafia permite a aplicação em qualquer substrato, sendo que a escolha do material estabelece o processo pelo qual será viável a impressão. Munari trabalha com o papel preto e a impressão serigráfica em azul fosco no primeiro terço deste livro, e no restante utiliza o offset.

A sequência de furos participa da história narrada. O pequeno furo circular que percorre todas as folhas pretas apresenta um ponto luminoso, associado à luz do vaga-lume. O amarelo observado através dos furos contrasta com as cores do papel e da ilustração, o que atrai o olhar do leitor.

Os furos representando uma gruta desenham aberturas diferenciadas como um percurso de caverna. Estes buracos são posicionados de tal maneira que sempre se vê o papel texturizado, criando a percepção de infinito. Conforme o leitor vira as páginas, o espaço da caverna se modifica, até o final do percurso, onde o texto anuncia que acabou o dia. Por outro lado, na contra-mão da leitura tradicional, os vazios são preenchidos pelo preto, que denota escuridão.

O leitor, após percorrer o trajeto de um dia, partindo da noite na cidade, percorrendo o dia na mata e na caverna, chega enfim à noite. Esta é representada, novamente, pelo preto do papel e pelos pontos luminosos amarelos, retomando os furos redondos do início.

Munari utiliza outro instrumento lúdico, a inserção do encarte. Um papel impresso dobrado e colado na página funciona de forma semelhante à janela, mostrando um desenho na frente enquanto esconde uma surpresa, instrumento presente no jogo de adivinhação. $O$ encarte, neste livro, aparece em dois momentos, simulando um baú de tesouros e no fundo amarelo. Este último guarda uma pequena e descontraída biografia do autor.

Semelhante ao uso do encarte, um pequeno caderno de 4 folhas vegetais, com um pouco menos de um terço da altura da página, é costurado junto ao papel texturizado. Folhas que simulam um rio subterrâneo, onde peixes nadam em diferentes profundidades.

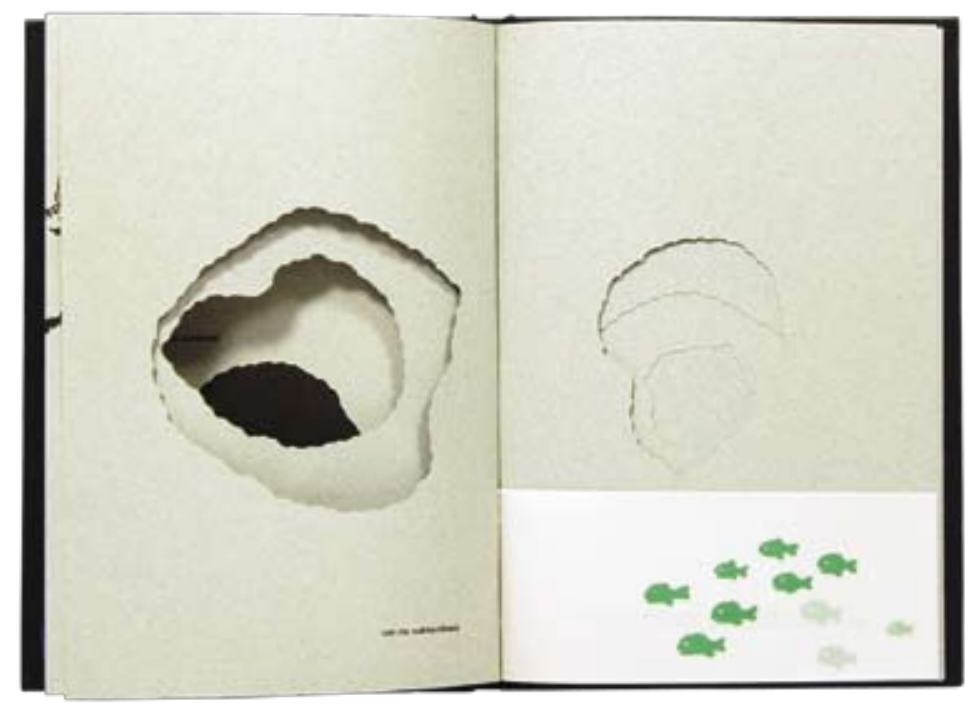




\section{PIÙ E MENO}

Corraini Editore, 2006

$145 \times 145 \mathrm{~mm}$

caixa com lâminas diversas

serigrafia

impresso na Itália

\section{[Più e meno}

Corraini Editore, 1970]
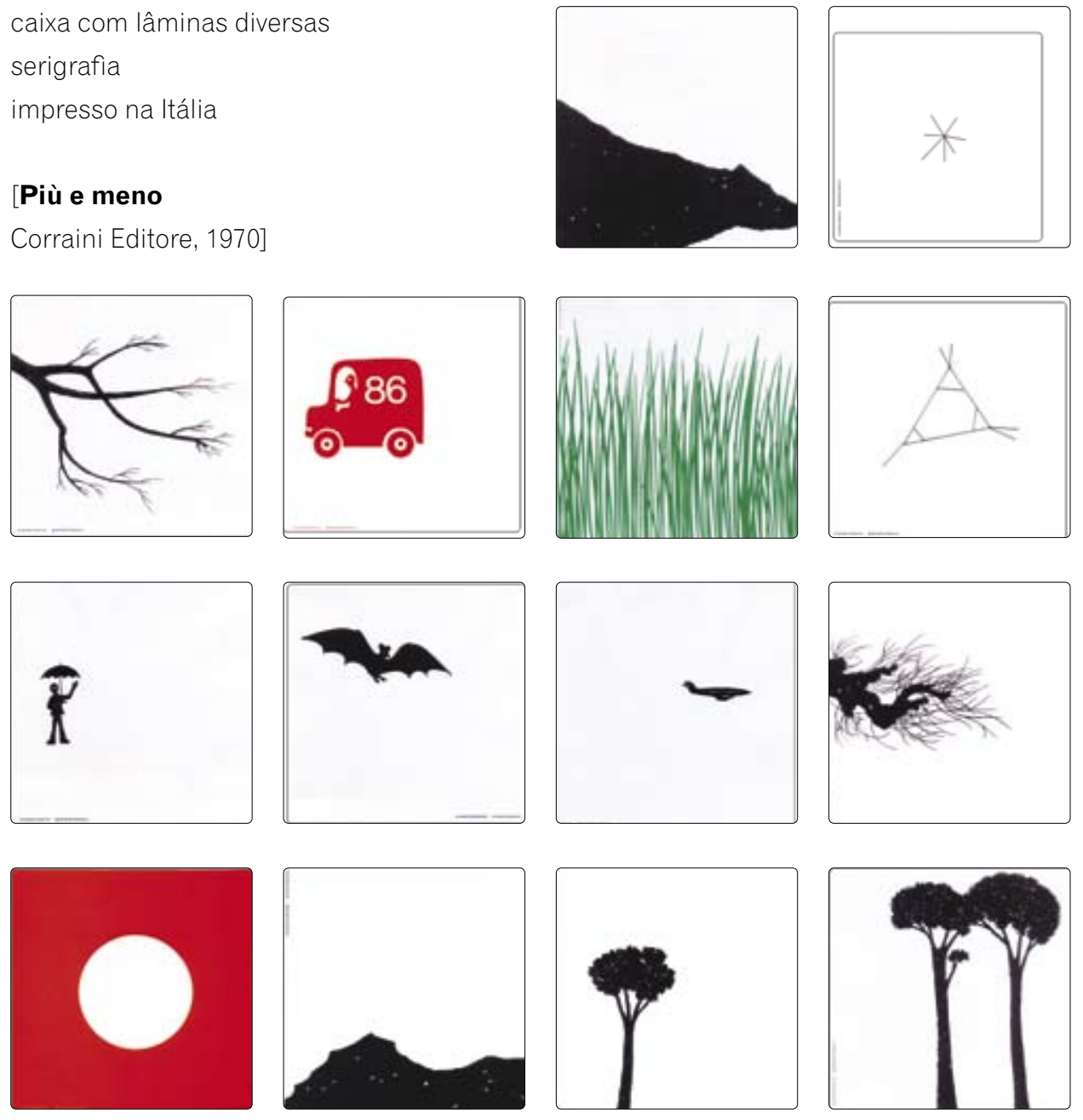

104
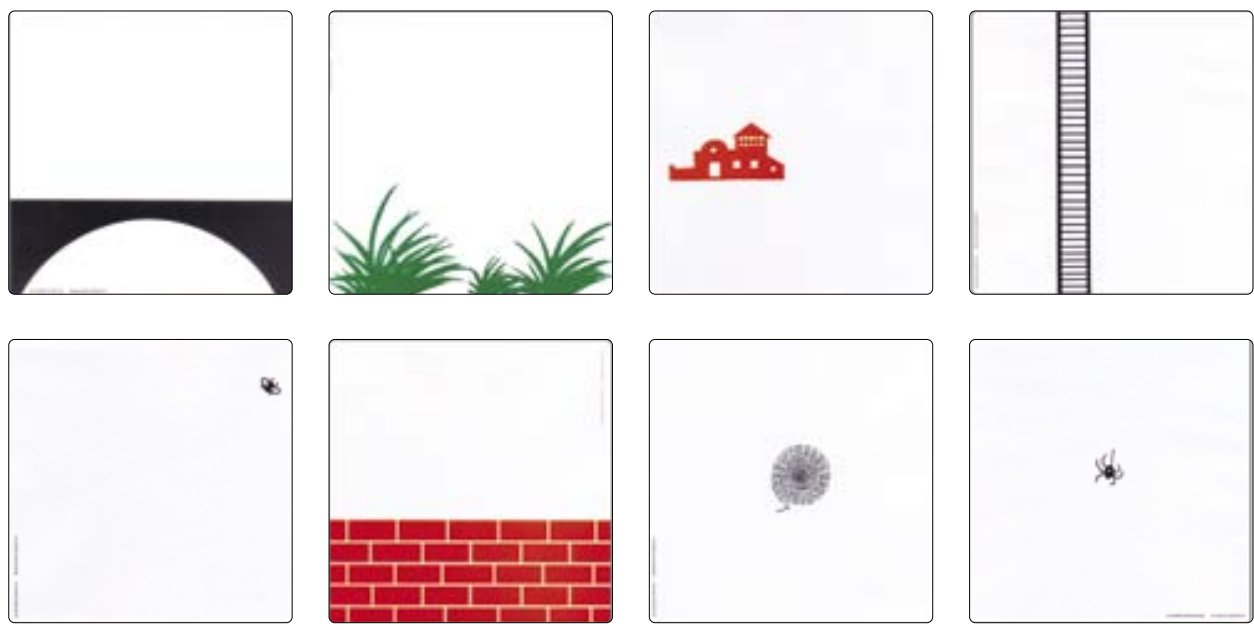

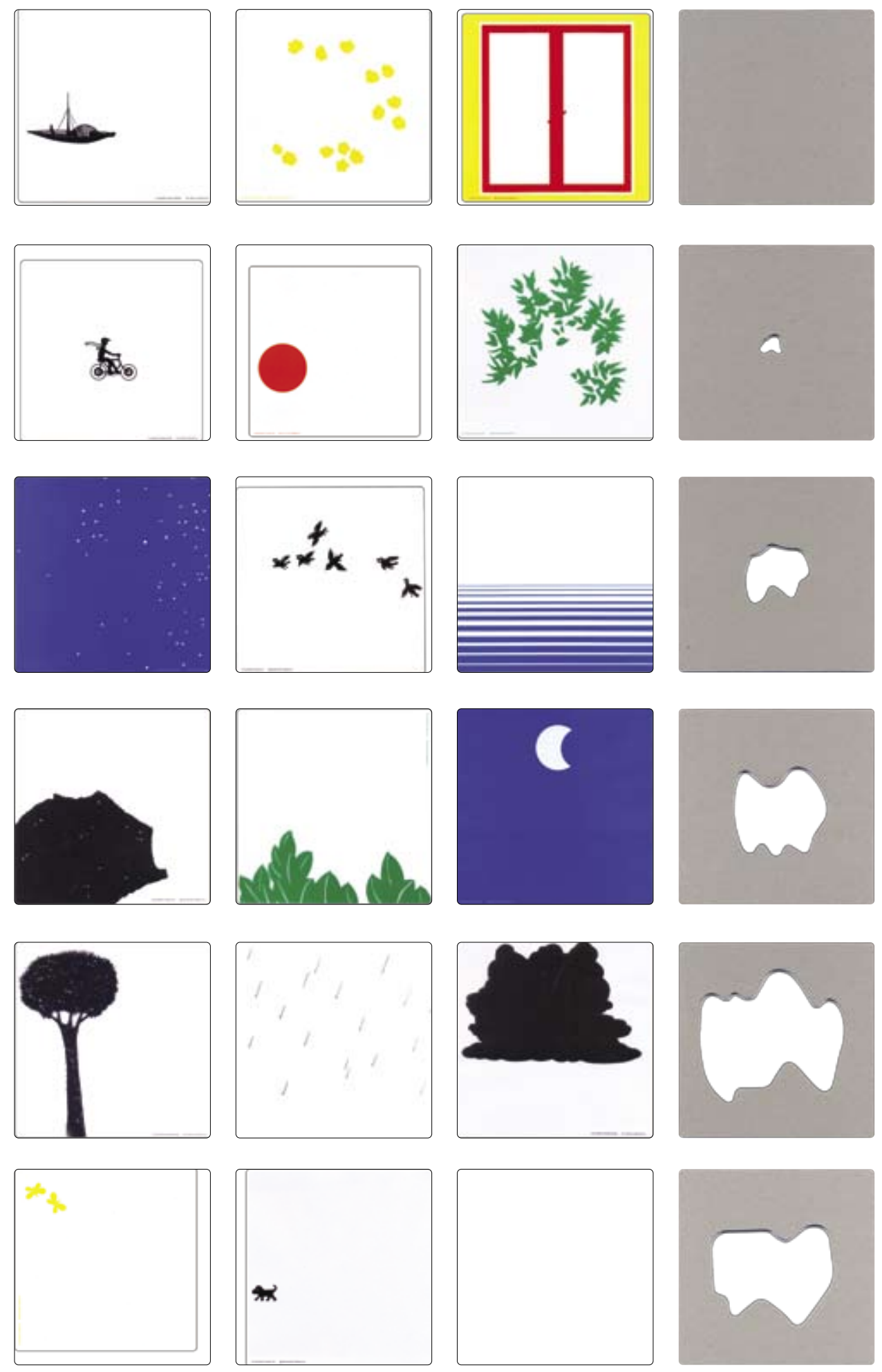
Più e meno é uma narrativa visual composta de 72 cartas com diversas imagens, com as quais o leitor cria sua própria narrativa. A maior parte das cartas, 48 das 72, é produzida em acetatos e impressa em serigrafia, permitindo a adição ou a subtração de personagens. Este livro-objeto estimula o desenvolvimento da fantasia e da criatividade.

O leitor é convidado a usar sua imaginação para compor divertidas histórias, por meio da sobreposição e subtração das cartas, combinando situações, personagens e ambientes. O jogo explora a percepção das cores, especialmente quando são adicionadas, bem como a percepção espacial, por meio de cartas com diferentes vazados.

Na caixa há alguns exemplos de como o leitor, criança ou adulto, pode utilizar sua criatividade. Uma folha com instruções descreve todos os elementos visuais impressos no acetato: pássaro, borboletas, cachorro, aranha, morcego, mosca, árvore, flores, folhas, ramos, troncos, arbustos, rochas, estrelas, neves, chuva, ponte, carro, um homem na bicicleta, estrada de ferro, guarda-chuva, casa, um muro, avião, barco, mar, céu e janela.

Elementos que podem determinar: o protagonista, quem fará a ação; o tempo, se é um dia ensolarado ou uma noite chuvosa; e o espaço, onde se passa a ação. A combinação das cartas permite um jogo com múltiplas histórias, no qual o leitor-narrador sente-se motivado, pela livre manipulação, a sempre voltar a este livro-objeto.

Neste jogo não se estabelecem regras de como o leitor-narrador deva conduzir sua história, bem como não há limite para o número de participantes, permitindo-se que de única narrativa participem mais de uma pessoa. O uso deste livro-objeto é aberto à criação individual.

\section{FORMATO}

As fichas são produzidas no formato quadrado de dimensões $145 \times 145 \mathrm{~mm}$. O formato possibilita elementos mais dinâmicos, uma vez que se pode rotacionar as imagens e alterar o sentido da ação.

Além do formato quadrado, as lâminas possuem os cantos arredondados, evitando, assim, que pequenos leitores se machuquem durante a manipulação, uma vez que o material se constituí de um substrato mais rígido. As lâminas soltas possibilitam liberdade de escolha, tanto na forma de sobreposições das lâminas quanto nas sequências em que são colocadas.
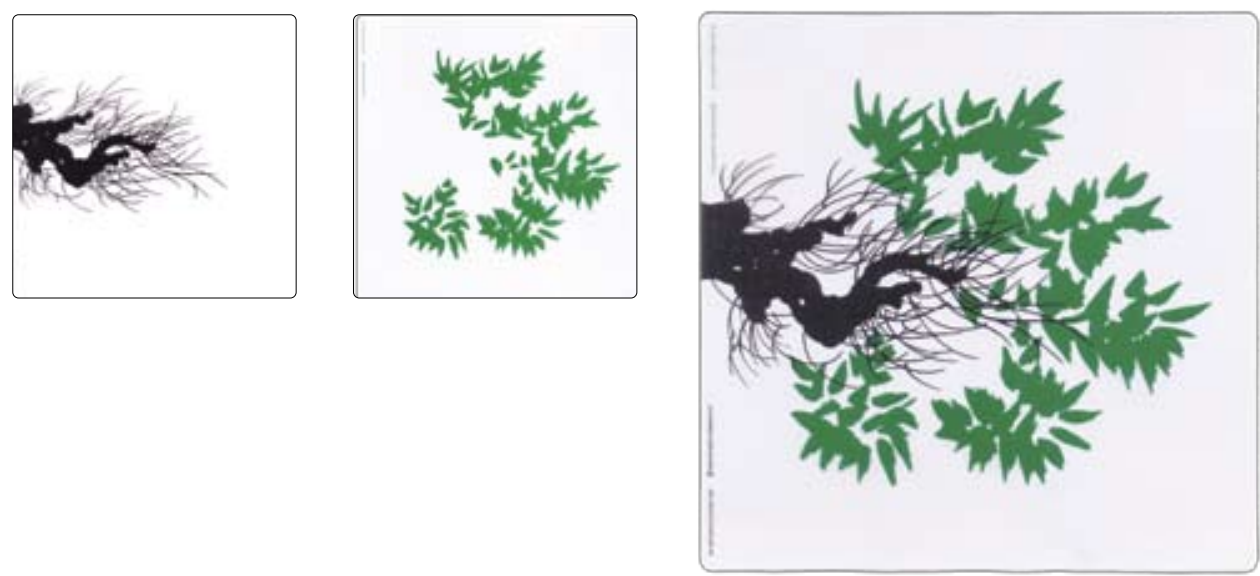


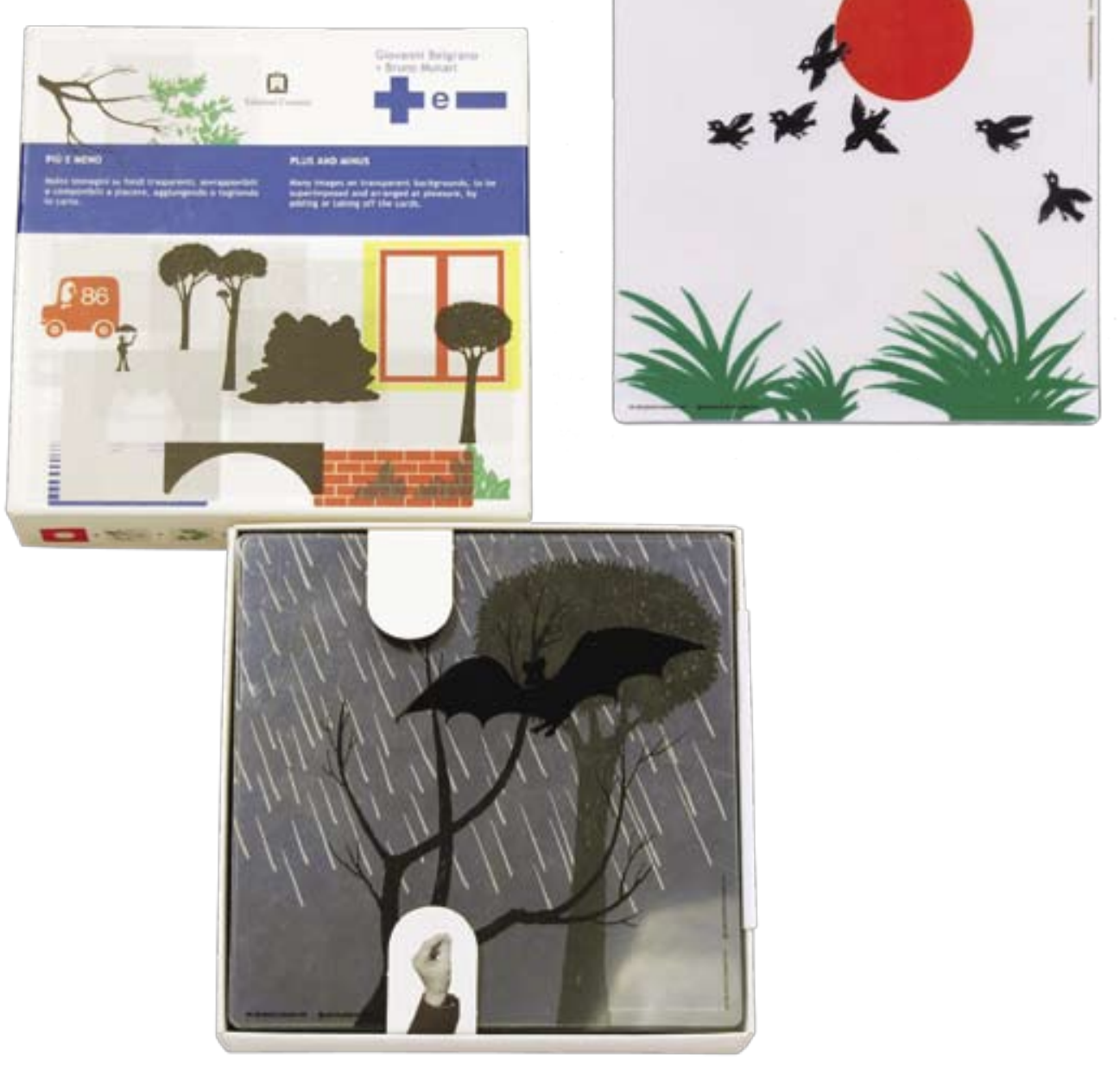

TIPOGRAFIA

A tipografia não participa deste livro-objeto. Più e meno é uma narrativa constituída apenas de imagens, sem qualquer presença de palavras. O texto presente na folha de instruções e na capa não é relevante para esta análise.

\section{ORGANIZAÇÃO DA PÁGINA}

Munari e Belgrano exploram um caráter mais experimental de narrativa, por isso os elementos visuais não respeitam qualquer malha estrutural. Por outro lado, obedecem a alguns padrões, como o de imagens de fundo totalmente sangradas.

Pode-se estabelecer algumas relações de diagramação das ilustrações com seu significado: as nuvens dispostas na parte central superior, as teias de aranhas no centro, as folhagens que combinam os ramos, os arbustos na parte inferior, os pássaros na parte inferior, mas tais posições são relativas a cada leitor, dependendo de como são rotacionadas. 

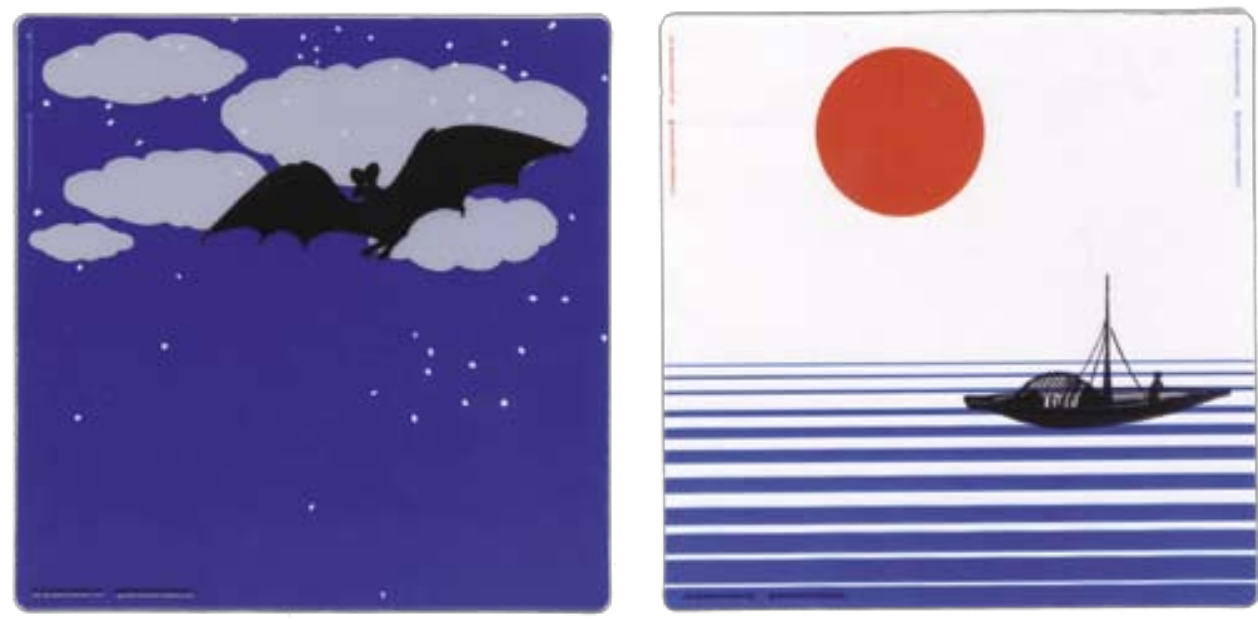

\section{LINGUAGEM VISUAL DAS ILUSTRAÇÕES}

Em Più e meno predominam as ilustrações de grande massa visual separada em lâminas. Elementos pequenos, como por exemplo a mosca, a aranha e as borboletas, tornam-se imagens frágeis quando comparadas ao conjunto.

O estilo das ilustrações assemelha-se de Na noite escura, desenhos limpos, sem muitos elementos decorativos. Imagens de simples entendimento, o que as tornam de leitura universal. Munari e Belgrano recorrem às imagens pictográficas, desenhos sem contorno e totalmente preenchidos em uma única cor, exceto na janela, ilustrada em duas cores.

As cores estabelecem uma relação direta com sua figuração, o verde para a vegetação; o azul para a noite e para a água; branco para a chuva, as nuvens e a neve; laranja para o sol. Os autores estabelecem nas cores secundárias o padrão cromático, e, por outro lado, brincam com a percepção das cores quando as lâminas são sobrepostas. Os personagens da narração, os animais e os humanos, são representados em preto, cabendo aos cenários as cores.

A leitura das lâminas difere-se pela sua posição no conjunto. Os desenhos coloridos apresentam um preenchimento chapado e semi-translúcido, viabilizando a mistura de cores, ao contrário do preto, que é totalmente opaco. A brincadeira com a transparência é também fornecida pela sobreposição do papel vegetal.

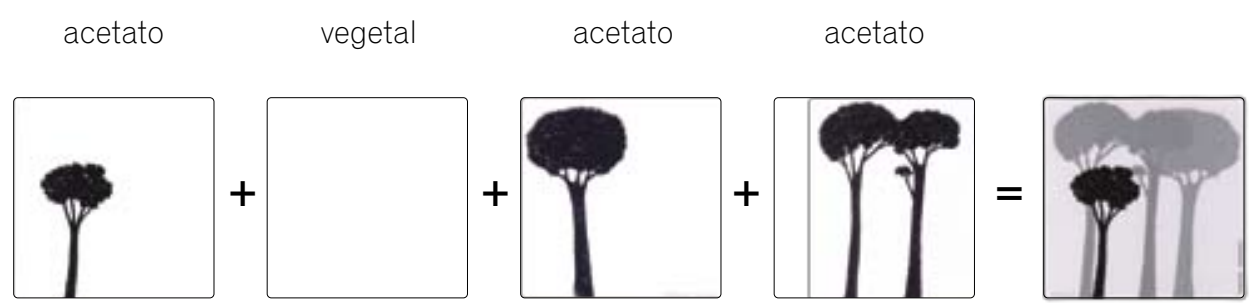



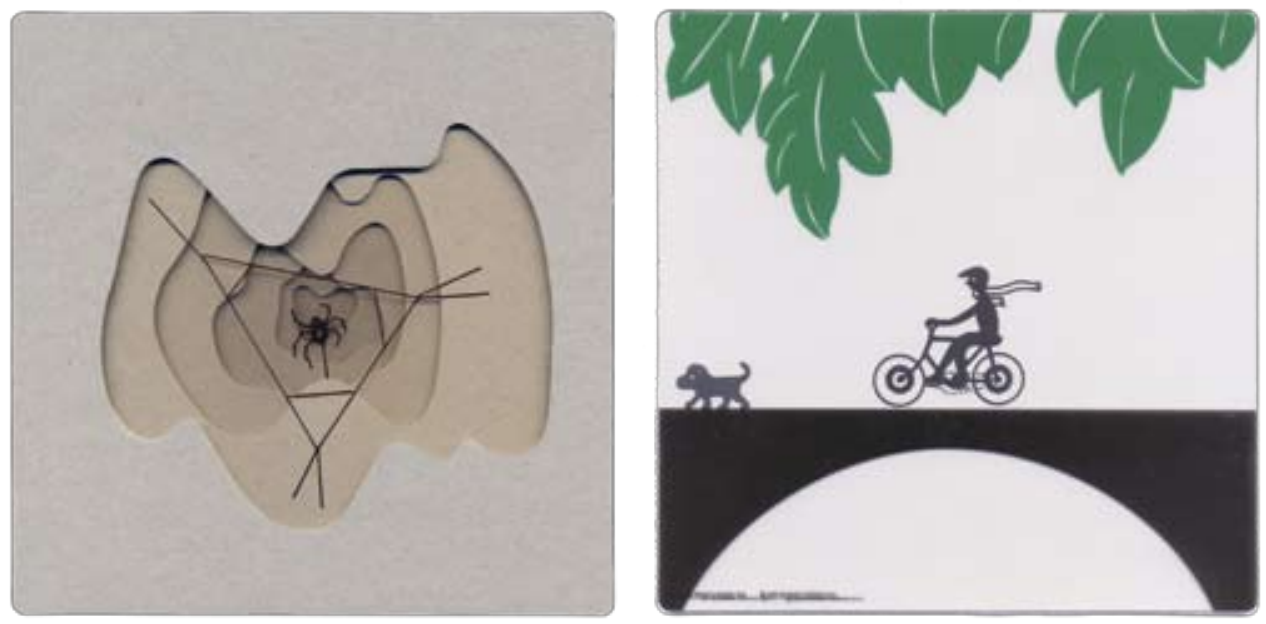

\section{PRODUÇÃO GRÁFICA}

Neste livro-objeto, utilizou-se quatro materiais diferentes: o acetato, o papel couché fosco, o papel vegetal e o cartão roller. O jogo de combinações destes diferentes materiais aguça a fantasia daqueles que o manipulam.

A impressão aparece apenas nas lâminas de acetato, em tinta translúcida que garante a permeabilidade visual, de forma que se enxergue o desenho sobreposto, bem como a mistura de cores. Munari e Belgrano criam uma brincadeira com a percepção das cores, mostrando as diferenças de percepção quando se altera a posição.

Na serigrafia, cada cor é obtida pela mistura das tintas, o que significa a necessidade de uma matriz para cada cor utilizada. $\mathrm{O}$ uso de diferentes cores no mesmo substrato traduz-se em maior tempo de produção e desperdício de material para encontrar o enquadramento preciso.

O papel couché branco fosco de gramatura superior a 240g não apresenta imagem. Um quadrado com os cantos arredondados, que serve de base para os acetatos. $O$ fundo branco, na sequência de acetatos, altera a percepção visual. O vegetal, assim como o couché, não apresenta ilustração. Trabalha com a semi-opacidade do material, fornecendo diferentes percepções para o encadeamento narrativo.

As lâminas de cartão contêm vazios desenhados em diferentes formas amebóides. Os buracos variam de tamanho obedecendo a uma progressão, do maior ao menor, até a lâmina sem buraco. Os desenhos simulam o mesmo efeito obtido na caverna de Na noite escura, trabalhando com a sobreposição dos vazios e seus respectivos desenhos. A espessura do cartão de 1,5mm, além da resistência material, fornece também a profundidade.

Todas as cartelas vêm acondicionadas numa caixa de papelão, impressa com o título e os nomes dos autores, bem como com exemplos de como se constroem as imagens narrativas. Esta caixa recebe laminação fosca e, internamente, apresenta uma cinta, que permite retirar as lâminas com facilidade. 
THE CIRCUS IN THE MIST

Corraini Editore, 2006

$210 \times 210 \mathrm{~mm}$

capa dura

offset

impresso na Itália

[Nella nebbia di Milano

Emme Editore, 1968]
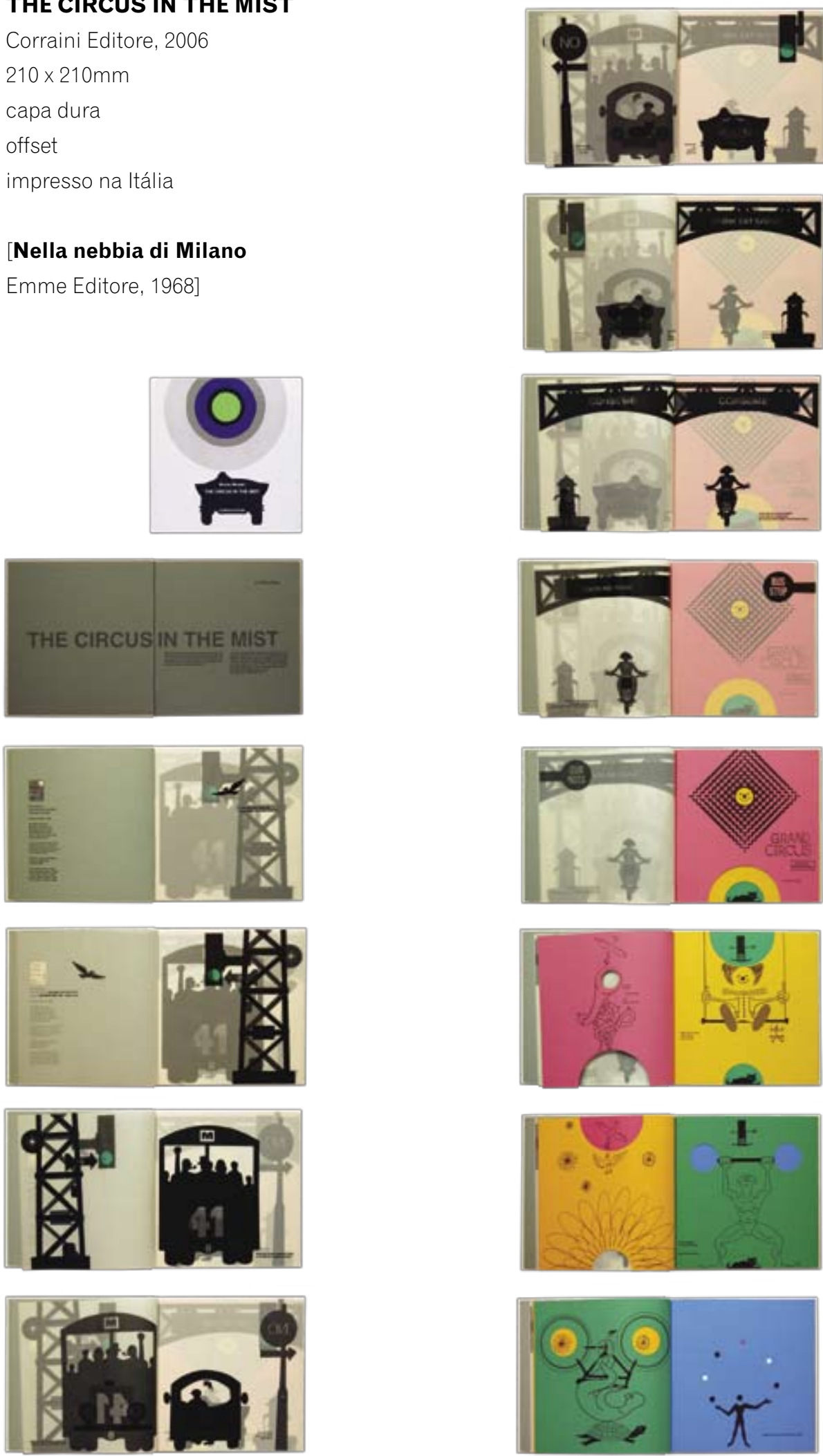

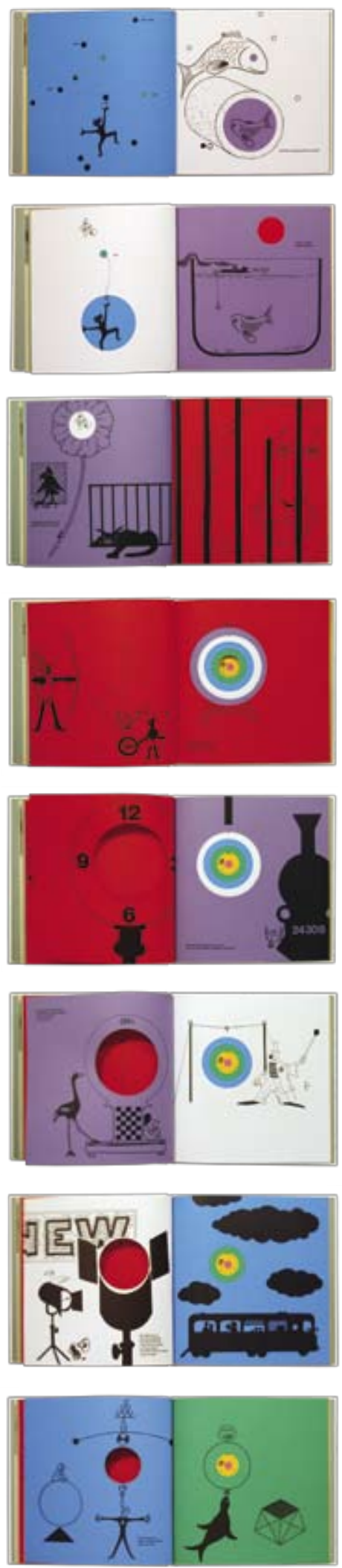
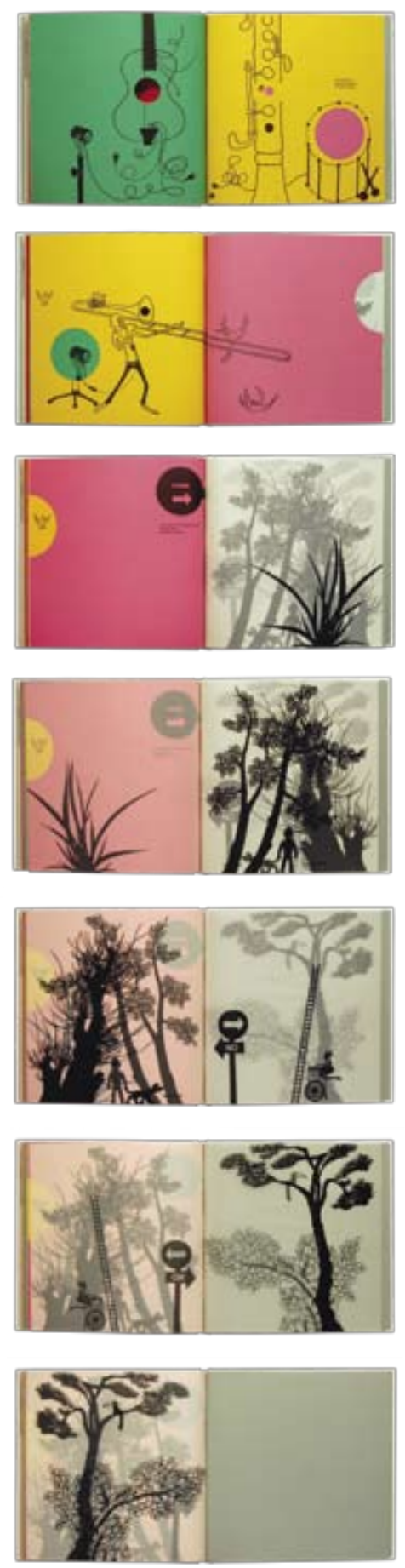


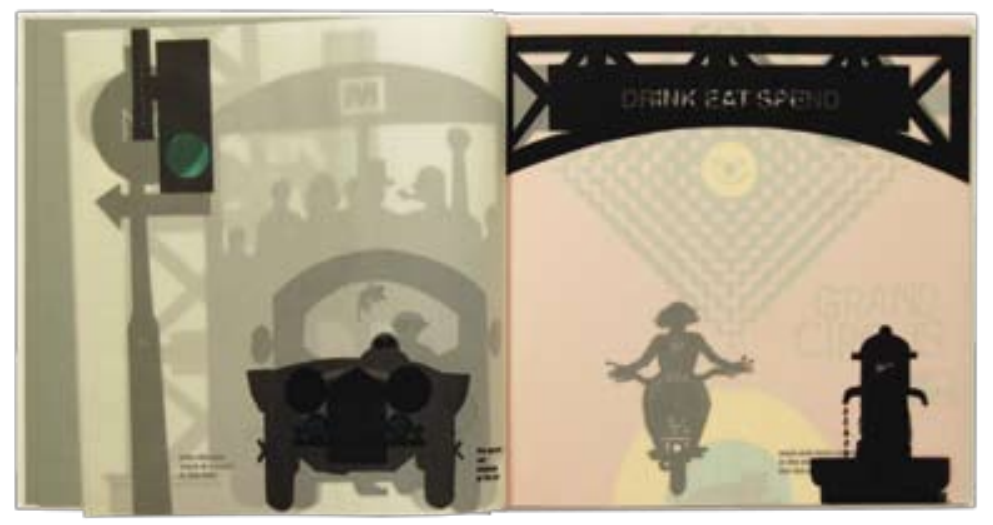

The circus in the mist é uma narrativa visual em que o leitor é levado à fantasia, em meio à neblina do inverno. Este livro-objeto inicia seu enredo com um passeio na cidade mergulhada na neblina, mostra o que acontece neste período com os pássaros, os carros, os semáforos e com toda a movimentação urbana.

Neste primeiro momento, por meio de ilustrações pretas impressas sobre o papel vegetal, Munari aproveita as propriedades deste material, sua translucidez, para brincar com elementos gráficos. Ao imprimir no verso de uma área impressa chapada de preto, consegue esconder uma surpresa no verso.

Quando o leitor, enfim, chega ao circo, é surpreendido com as cores em contraste aos tons neutros iniciais. Munari utiliza-se de folhas coloridas com diferentes recortes para obter o jogo de personagens e destaques, de forma a deslocar o olhar do lugar comum. Todas as ilustrações são impressas em preto, ora realizadas com linhas, ora com desenhos chapados. Os personagens do circo desfilam com seus números a cada folhear de página. A harmonia das cores associada aos vazados nas páginas resulta num produto com projeto gráfico cuidadoso. A disposição das folhas coloridas estrutura a montagem dos cadernos costurados.

Por fim, o leitor é conduzido de volta à casa pelo meio do parque, retornando ao preto e ao branco translúcido do vegetal. Neste caminho encontra vegetação, aves, um cachorro e uma seta indicando o sentido da leitura, num tom de brincadeira e humor, característico das obras de Munari.

O lúdico, neste livro, é estabelecido pelo jogo com os recortes e com a perfeita apropriação dos materiais, associando diferentes percepções de leitura pela translucidez e pela sobreposição dos vazados. Munari brinca com as informações escondidas no vegetal, bem como apresenta diferentes respostas ao mesmo formato redondo da faca.

\section{FORMATO}

The circus in the mist apresenta um formato quadrado $210 \times 210 \mathrm{~mm}$. Esta dimensão, se considerada a folha BB, 960 ×660mm, produzirá 12 folhas com reduzida perda de material. $O$ formato quadrado possibilita a Munari brincar com a impressão espelhada nos papéis vegetais. Permite, ainda, fechar um enquadramento visual a cada página colorida. 


\section{TIPOGRAFIA}

A versão utilizada para a análise é uma tradução do italiano para o inglês, por isso as relações estabelecidas se referem à presente edição. A tipografia utilizada é uma fonte sem serifa da família Frutiger. No texto de abertura usou-se tipo regular, enquanto no miolo, bold. A altura do corpo é estabelecida em 9 pontos com a entrelinha de 12 pontos.

A massa de texto é pequena, dividida em no máximo 4 linhas, tamanho característico da narrativa do picture book. Semelhante ao que ocorre no livro Na noite escura, o texto apresenta-se sem pontuação e todo em caixa baixa, desenhando manchas uniformes.

Na página que anuncia o circo o texto é escrito a mão e simula um cartaz de divulgação do ensaio geral. Esta diferenciação separa este texto daquele do narrador, apresentando uma proposta de um cartaz improvisado.

O tipo utilizado na capa é o mesmo do miolo, Frutiger bold. O título aparece em caixa alta, no corpo 20 pontos, enquanto o nome do autor, com o mesmo corpo, é escrito em caixa alta e baixa. O nome da editora segue o padrão do título, mas num corpo menor. Estes textos são diagramados como blocos centralizados na página.
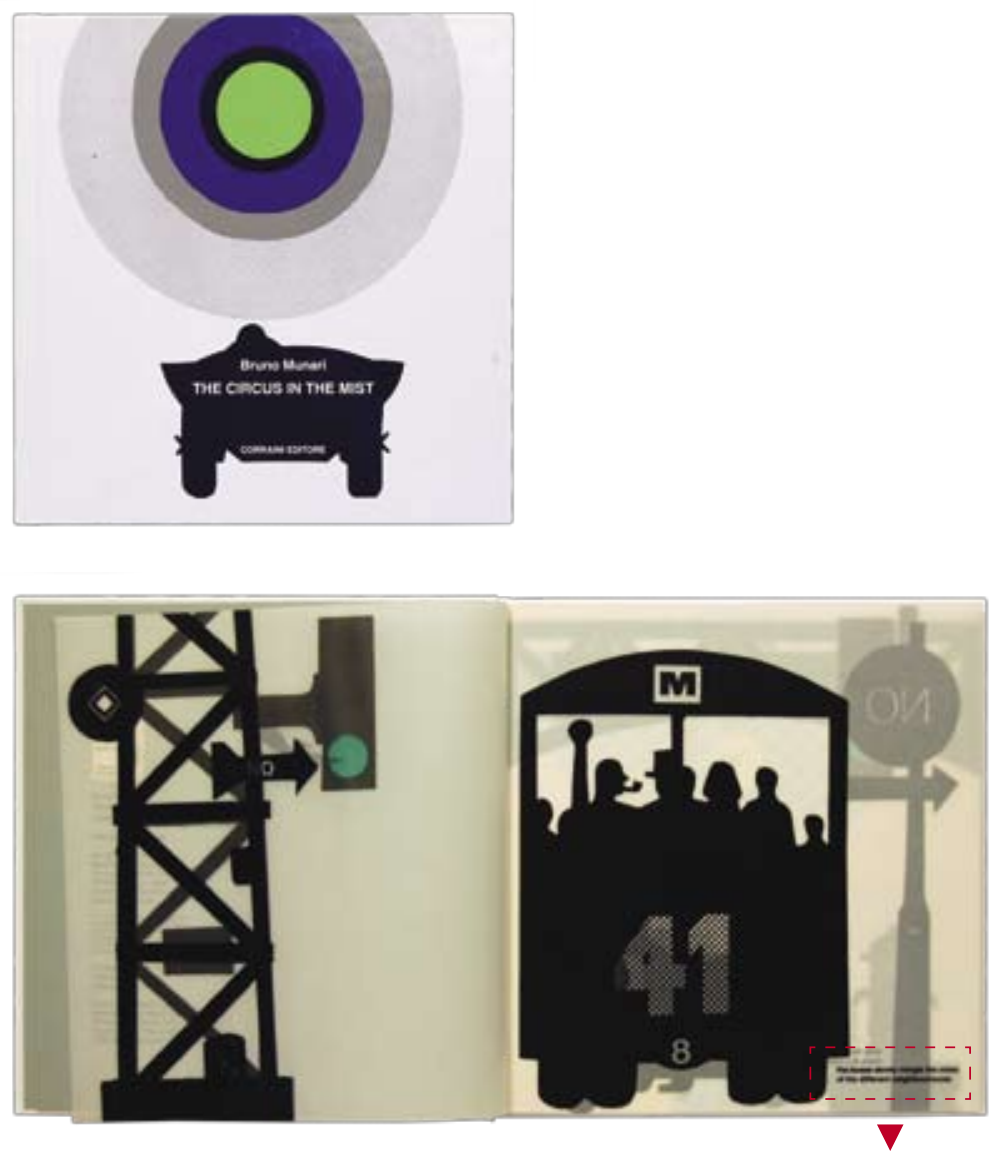


\section{ORGANIZAÇÃO DA PÁGINA}

A malha tipográfica é organizada em função da entrelinha, bem como em função do peso visual das imagens. As caixas de texto estão, predominantemente, na página par, mas, quando a página ímpar narra outra cena, um pequeno texto aparece. Observa-se que grande parte dos blocos de texto estão inseridos na parte inferior das páginas.

Neste livro não existe a organização em colunas. O alinhamento mais recorrente é o posicionamento junto às margens. Já o alinhamento do texto na caixa é quase sempre à esquerda. As imagens, em muitos casos, funcionam como linha guia para posicionar, horizontalmente, os textos, uma vez que elas delimitam o espaço da página.

As ilustrações são posicionadas no vegetal pensando no efeito da sobreposição, em como os elementos se fundem para formar novas imagens. Por isso não adotam nenhuma regra, ora sangrando totalmente, ora respeitando uma margem.

Nos papéis coloridos os vazios dos recortes orientam a posição das imagens participam como ilustração. Os desenhos preenchem grande parte do campo da página, sem a presença de uma malha estrutural.

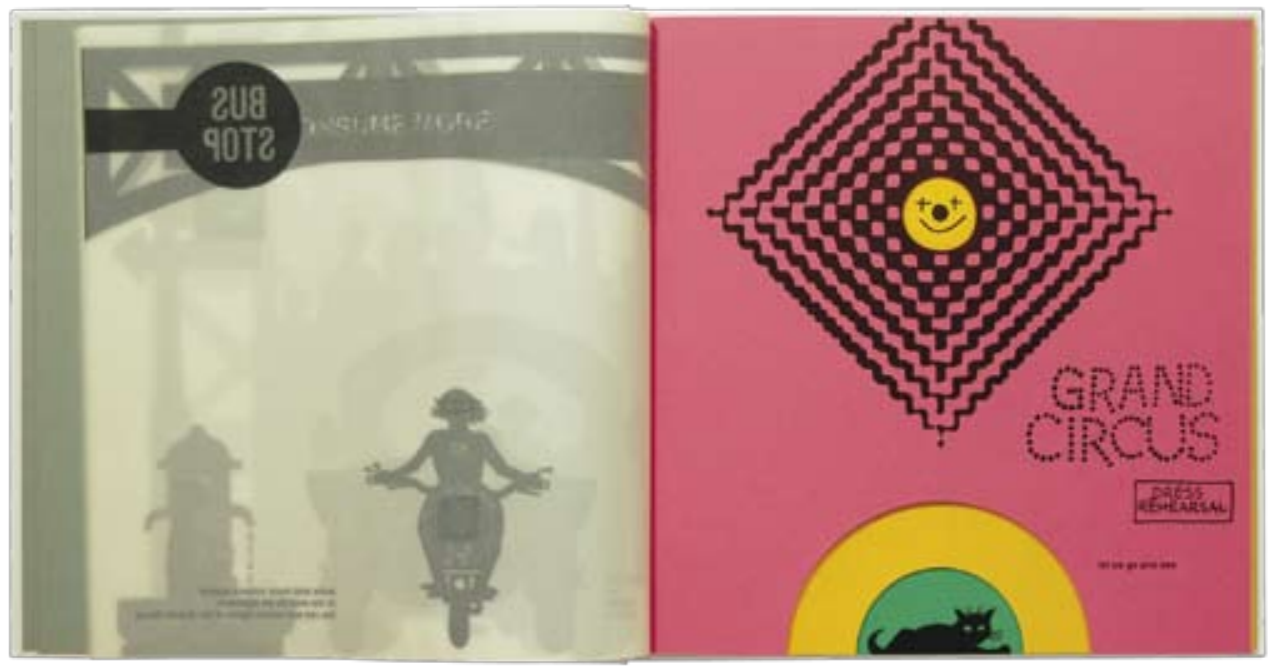

\section{LINGUAGEM VISUAL DAS ILUSTRAÇÕES}

Neste livro, dois estilos de ilustrações são trabalhados: com e sem preenchimento das imagens. No papel vegetal, por exemplo, os desenhos possuem uma massa densa de preto, sem contorno, semelhante das ilustrações de Na noite escura. Contudo, neste livro, Munari adiciona, no verso das páginas, detalhes às cenas, o que resulta numa brincadeira visual, um estímulo a mais para que o leitor o explore.

As massas bem delimitadas permitem a leitura das imagens através da semiopacidade, simulando os percursos na neblina, da cidade no começo, e do campo no final. O vegetal fornece, além da profundidade, o ritmo da narrativa. O leitor, lentamente, visualiza as imagens conforme avança no livro. 


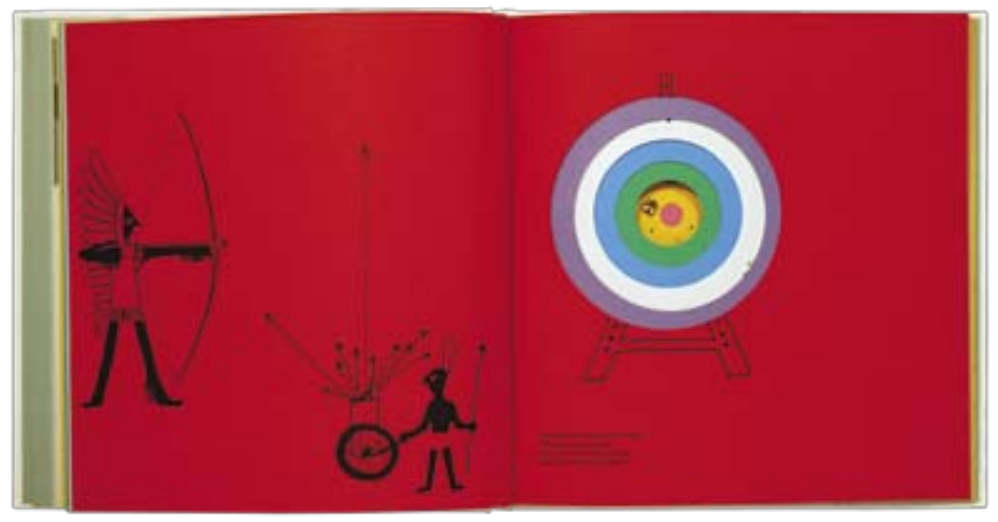

As folhas coloridas representam a magia do circo. As ilustrações narram diversas cenas do espetáculo, animais, palhaço, levantador de peso, malabarista, tambor, apresentações musicais. Impressas em preto, as ilustrações deixam as cores para o papel. Dessa forma, a cor da página não briga com as cores visualizadas nos vazados dos recortes, e se contrapõe à cor da página dupla.

As ilustrações impressas na parte colorida são caracterizadas pela leveza dos contornos desenhados, seu preenchimento é restrito a pequenos detalhes ou a situações em que é necessário para compor o peso visual.

\section{PRODUÇÃO GRÁFICA}

Neste livro, diversos recursos gráficos são explorados, sobretudo os ligados à diferença de materiais, como a apropriação da transparência do vegetal de gramatura $112 \mathrm{~g} \mathrm{e}$ das cores vibrantes do papel, similar ao colorplus, de gramatura $120 \mathrm{~g}$. Munari utiliza papéis coloridos ao invés de imprimir o fundo com dois propósitos de acabamento: os refiles laterais são, visualmente, mais atrativos, e não geram uma carga excedente de tinta, o que enrugaria o papel e deixaria odor.

O processo de impressão, tanto no vegetal como nas folhas coloridas, é o offset. No vegetal impresso em duas cores, preto e verde, enquanto nas folhas coloridas impresso apenas no preto, deixando o uso das cores ao encargo das folhas.

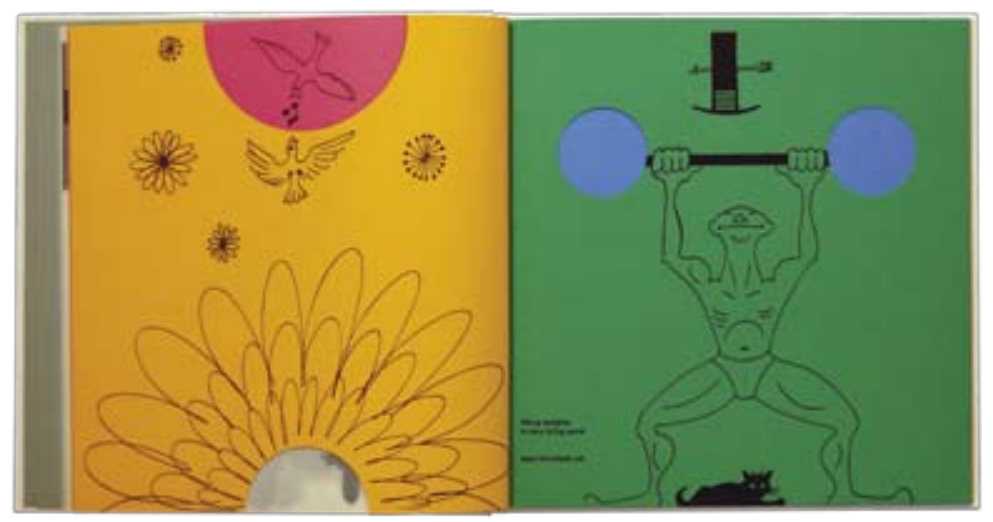




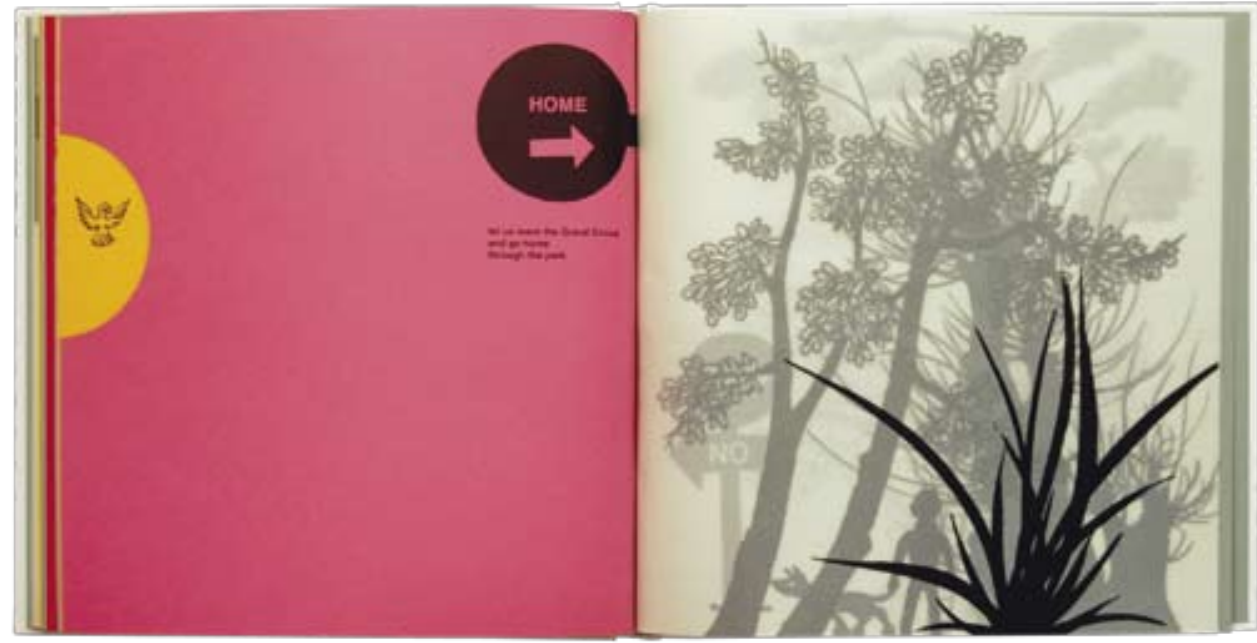

O trabalho com os recortes fornece uma poética visual. Os vazados instigam o ol har do leitor a entender a sequência de cores e de imagens propostas. Ao mesmo tempo que estabelecem a curiosidade sobre o que está por vir. A página trabalha aqui com o mesmo mecanismo lúdico da janela, escondendo a resposta e fornecendo uma pista.

Munari trabalha com o recorte em ambas as páginas coloridas da dupla. Assim, de um lado da página o desenho do recorte complementa um significado na ilustração, e no verso o significado proposto é diferente. Um recurso que estimula a fantasia e diverte o leitor.

As facas aplicadas possuem a mesma forma circular, o que difere são suas posições na página e suas dimensões. Diferente de Na noite escura, em que os vazados se sobrepõem ao mesmo papel, neste livro-objeto o cheio e o vazio se contrastam. O uso da faca especial apresenta, assim, uma diferente proposta visual.

A sequência de cor no livro indica que seu uso foi pensado na divisão em cadernos, separados pelo material. Assim, tem-se dois cadernos de papel vegetal e um de folhas coloridas. A edição analisada tem a lateral refilada e colada, ao invés de costurada, mas o livro foi projetado para receber a costura. Uma possível explicação para esta versão está na espessura do caderno colorido, que teria inviabilizado a costura.

Impressa em offset, a capa dura de lombada quadrada recebe uma laminação briIhante para a proteção do fundo branco. 
A investigação gráfica consiste em estudos de projeto do livro-objeto infantil com o objetivo de experimentar processos de produção e formas de narrativa por meio de suportes que propiciem o lúdico. O objetivo é a criação de alguns protótipos de livro-objeto sem estabelecer uma faixa etária para o leitor.

Os capítulos anteriores servirão de base teórica para direcionar os estudos práticos, dessa forma confrontando a teoria com a prática de projeto. Em todas as investigações procurou-se testar caminhos alternativos à forma tradicional do design de livros.

Os trabalhos gráficos de Bruno Munari e Paul Rand inspiraram parte das investigações aqui desenvolvidas. A partir de temas simples como: a cidade, os números, a poesia, os experimentos mostram diferentes caminhos para alcançar o lúdico.

O produto final das experiências práticas são objetos artesanais, demonstrando como o projeto poderia ser viabilizado pela indústria gráfica. Os estudos propostos não têm a finalidade de se inserir no mercado editorial, por isso não será discutida sua viabilidade econômica.

O grau de desenvolvimento dos trabalhos é variável, porque o objetivo destes estudos é a investigação de projeto, procurando discutir os conceitos em cada livro-objeto. Metodologicamente, os experimentos estão agrupados de acordo com o tipo de instrumento lúdico.
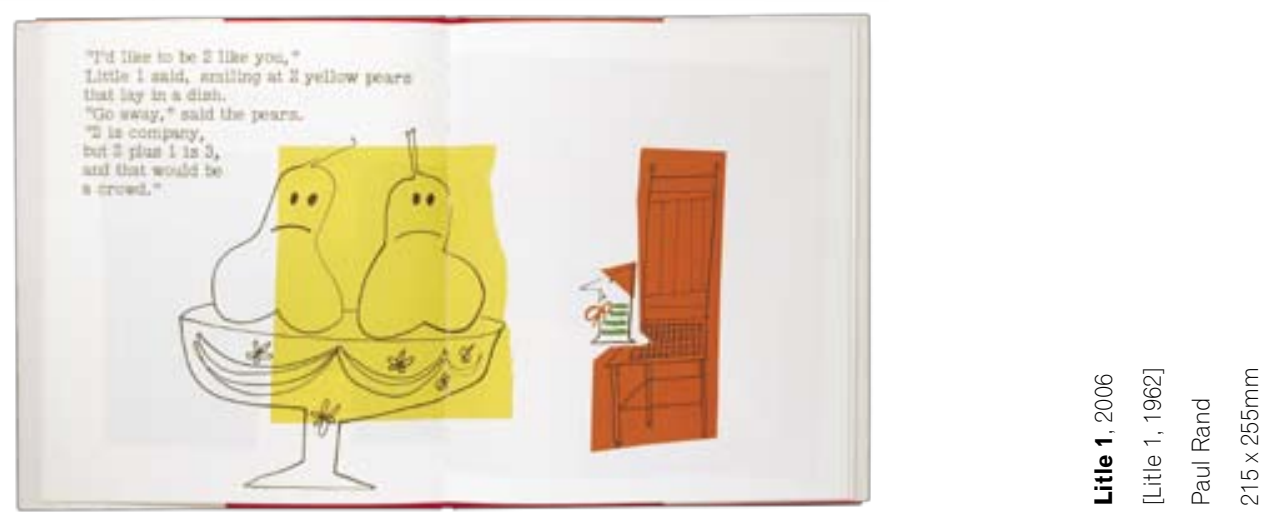

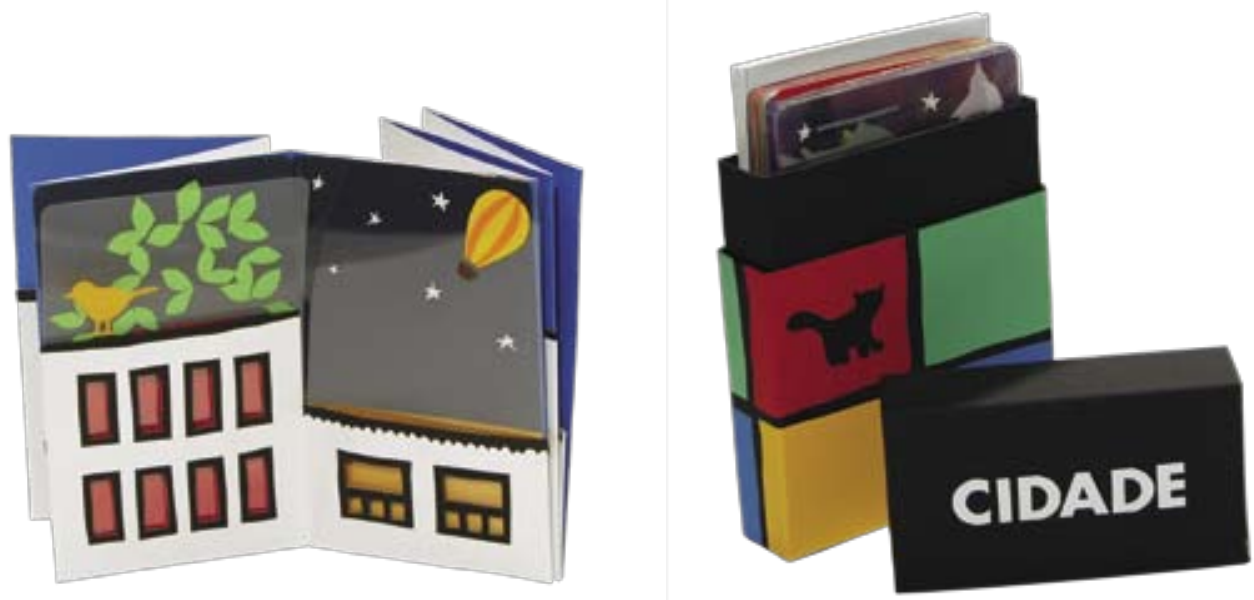

A proposta deste experimento é trabalhar com a narrativa visual, na qual cada leitor constrói sua própria história. O jogo aplicado neste estudo é inspirado no Più e meno, de Munari e de Belgrano.

Um eixo central, composto de uma carta dobrada em sanfona, compõe o cenário da narrativa. Os estudos desenvolvidos nesta pesquisa trabalham com o tema da cidade e do fundo do mar, utilizados como estímulo inicial à fantasia. Esse eixo propõe diferentes formas de manipular o livro, do folhear tradicional à leitura linear da tira aberta.

As lâminas soltas contêm os elementos que, associados ou não, compõem a narrativa. Os acetatos apresentam os personagens da história, mas cabe a interação do leitor nesta composição.

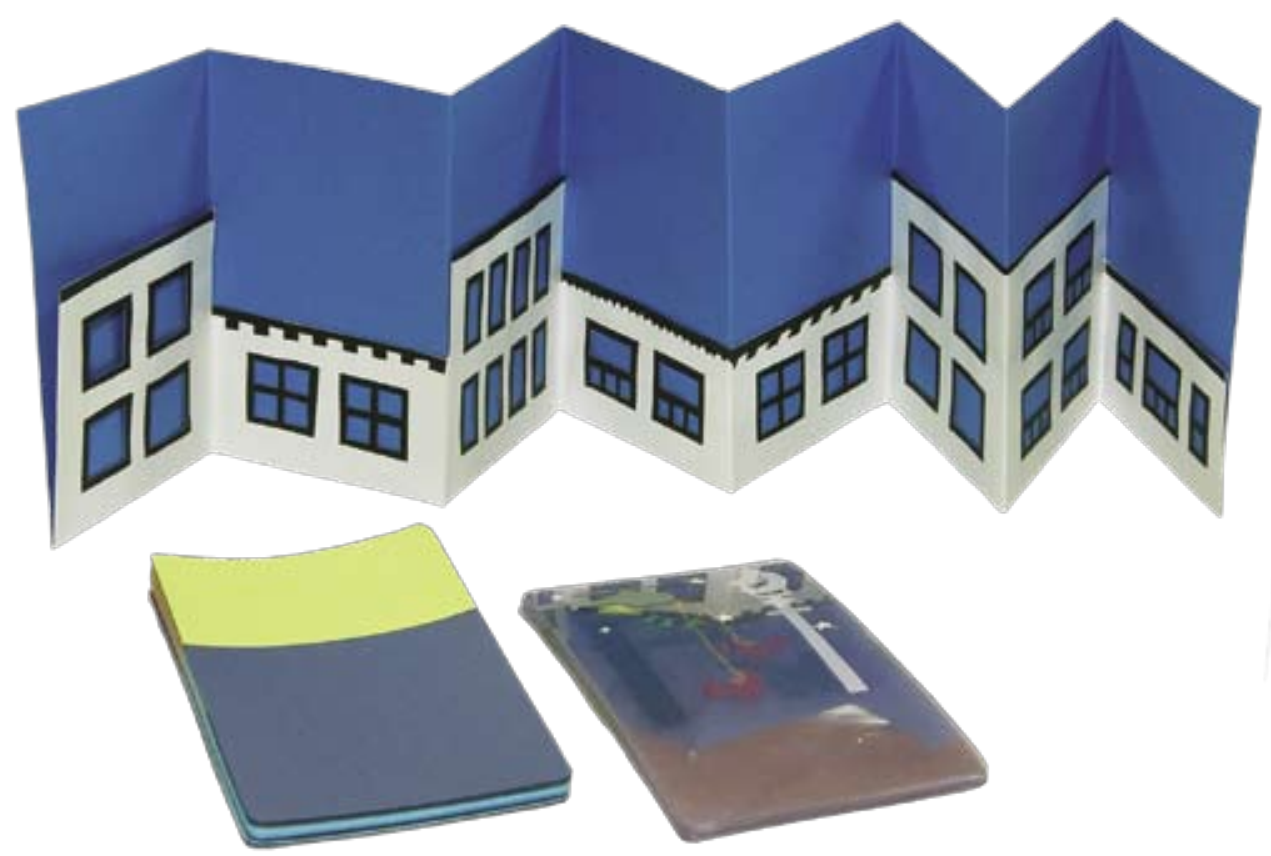


Este livro-objeto propõe uma obra aberta a outros temas, similar a uma coleção. Assim como fundo do mar e cidade, cabe explorar nesta estrutura diferentes habitats, como por exemplo a floresta ou os subterrâneos.

Este experimento adota a proporção $110 \times 175 \mathrm{~mm}$ fechado, medida extraída da razão áurea, que estrutura a linha divisória da narrativa. Estas medidas levam em conta a melhor forma de se aproveitar o papel de proporção $960 \times 660 \mathrm{~mm}$.
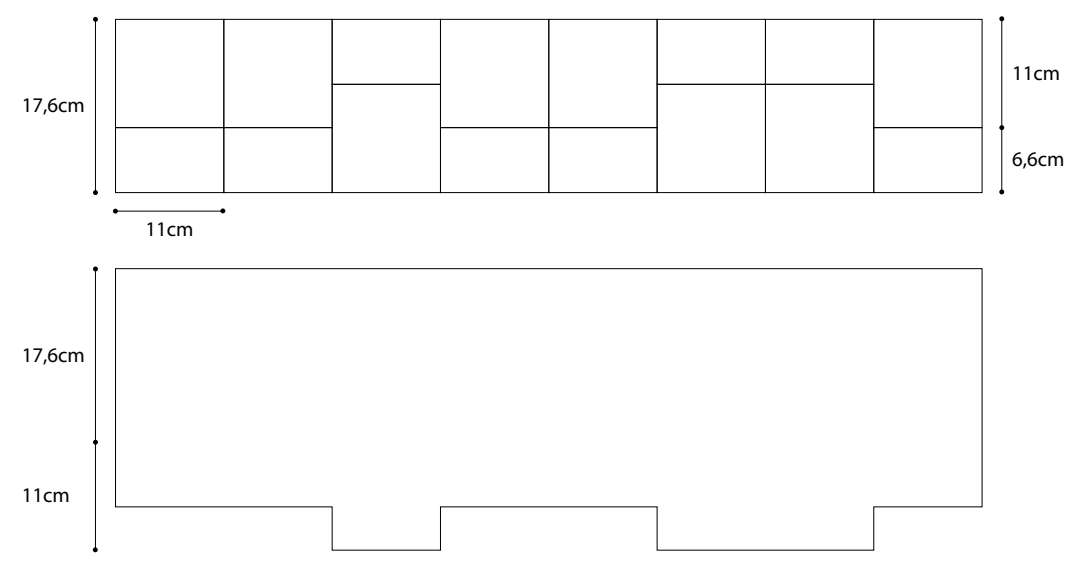

Outras relações foram testadas antes de chegar à proporção final, buscando obter uma medida harmônica. No eixo horizontal, investigou-se o centro visual e alguns possíveis deslocamentos, experiências que conferem movimento ao cenário de fundo.
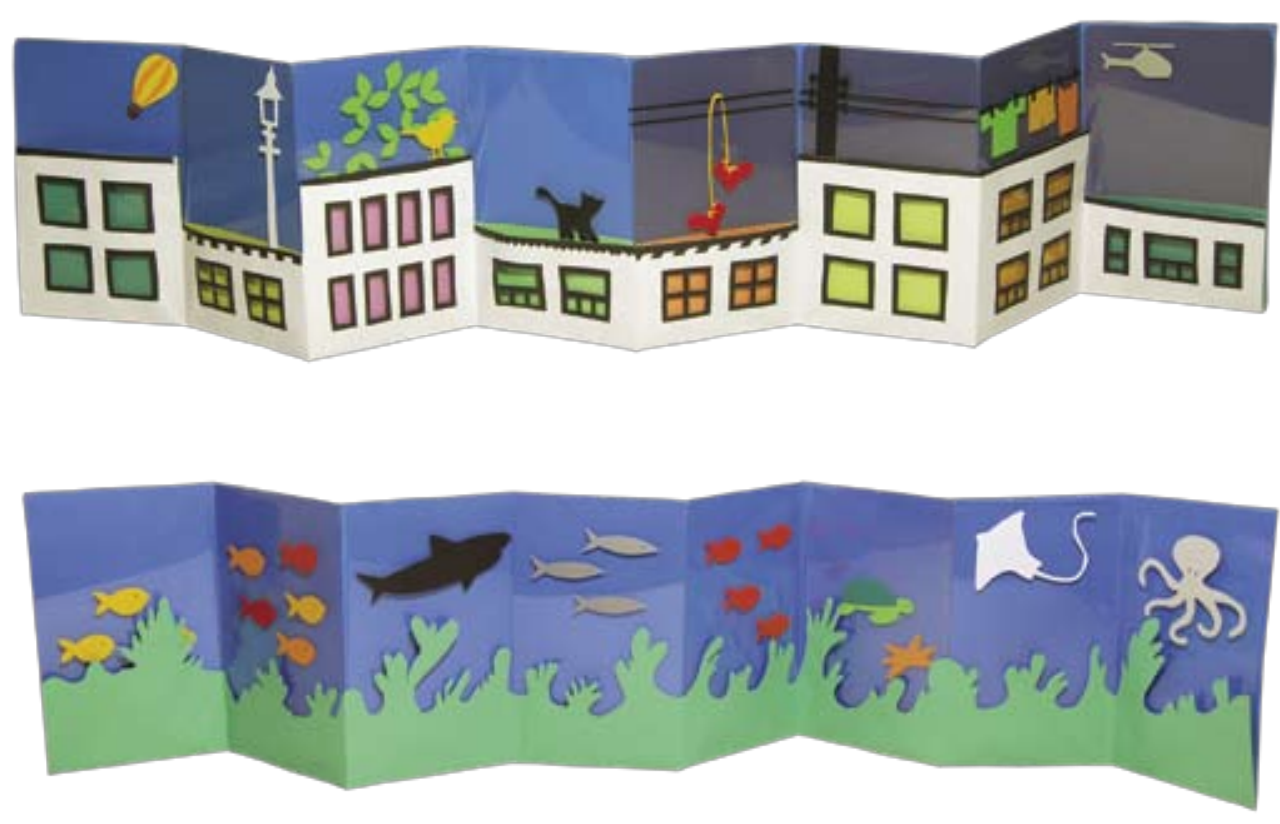


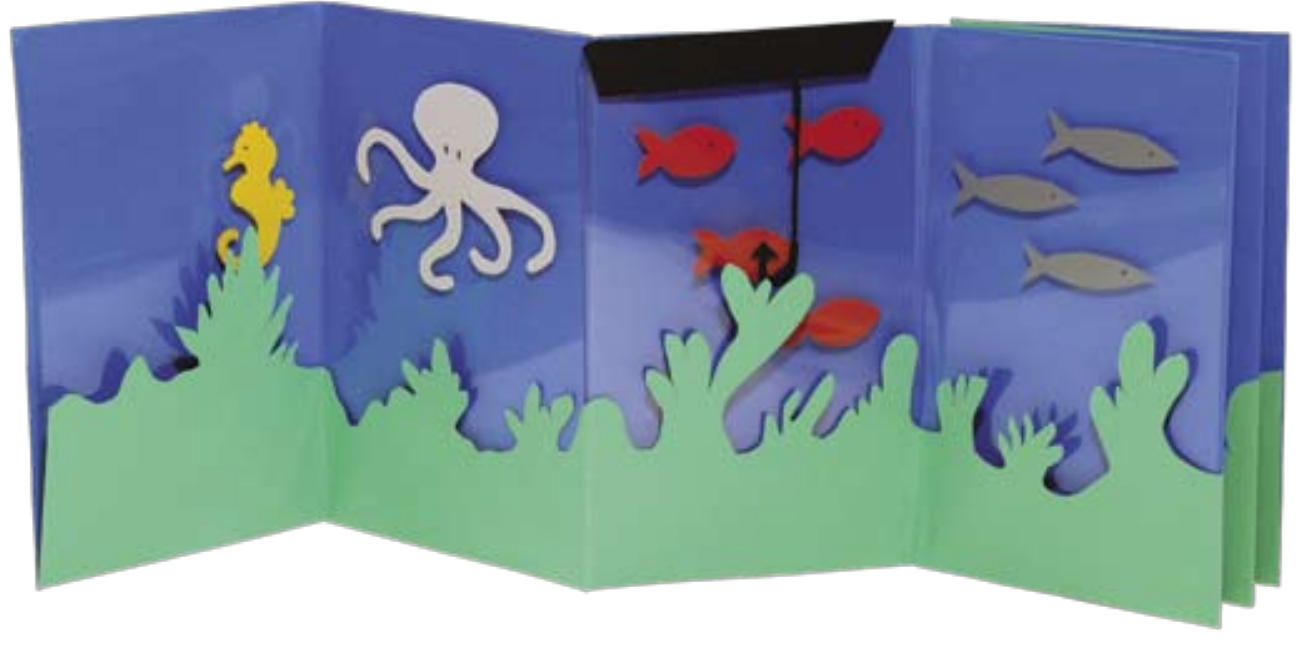

As páginas seguem dispostas lado a lado, organizando uma sequência linear. 0 fundo azul representa o céu, no experimento da cidade, e água, no experimento do fundo mar. Optou-se em trabalhar com poucas cores na sanfona, no mar, azul e verde, e na cidade, azul, branco e preto, deixando as cores restritas às lâminas, o que permite direcionar o olhar.

Na cidade, as cores são trabalhadas, além dos personagens, nas janelas vazadas e no azul do céu, o que deixa à escolha do leitor a composição cromática. Lâminas de diferentes tons de azul narram a mudança de tempo. Estas lâminas contêm cores diversas na parte inferior para enquadrar nas janelas.

A sanfona do fundo é composta por uma única tira de papel, que depois é dobrada e colada nas pontas para formar o envelope. No experimento, utilizam-se duas folhas de gramatura $90 \mathrm{~g}$ empastadas. Durante o processo, foram testadas diferentes gramaturas, porém folhas de maior gramatura oferecem resistência às dobras e rasgam, o que inviabiliza sua execução. Em uma produção industrial, poderia se imprimir em ambos os lados, uma única tira de papel de gramatura superior a 240g, e utilizar o vinco para suavizar o problema da dobra.

A narrativa é composta pelos personagens nas lâminas de acetato, ilustrações que permitem a troca e a atividade lúdica. Os desenhos caracterizam-se pela ausência de contornos e pela massa cromática uniforme. Utiliza-se do recorte para ilustrar.

As cartas soltas recebem desenhos produzidos por adesivos vinis recortados, mas estes poderiam ser impressos em serigrafia. Opta-se pelo uso restrito de cores por lâmina, pensando na viabilidade da serigrafia. Os cantos das cartas são arredondados para que os materiais rígidos, PVC cristal de 0,3mm e colorplus $180 \mathrm{~g}$, não machuquem o leitor durante a manipulação.

A capa é apresentada em forma de caixa, permite que as fichas soltas possam ser guardadas com facilidade. A caixa segue a mesma proporção áurea da sanfona dobrada, $125 \times 185 \mathrm{~mm}$. 

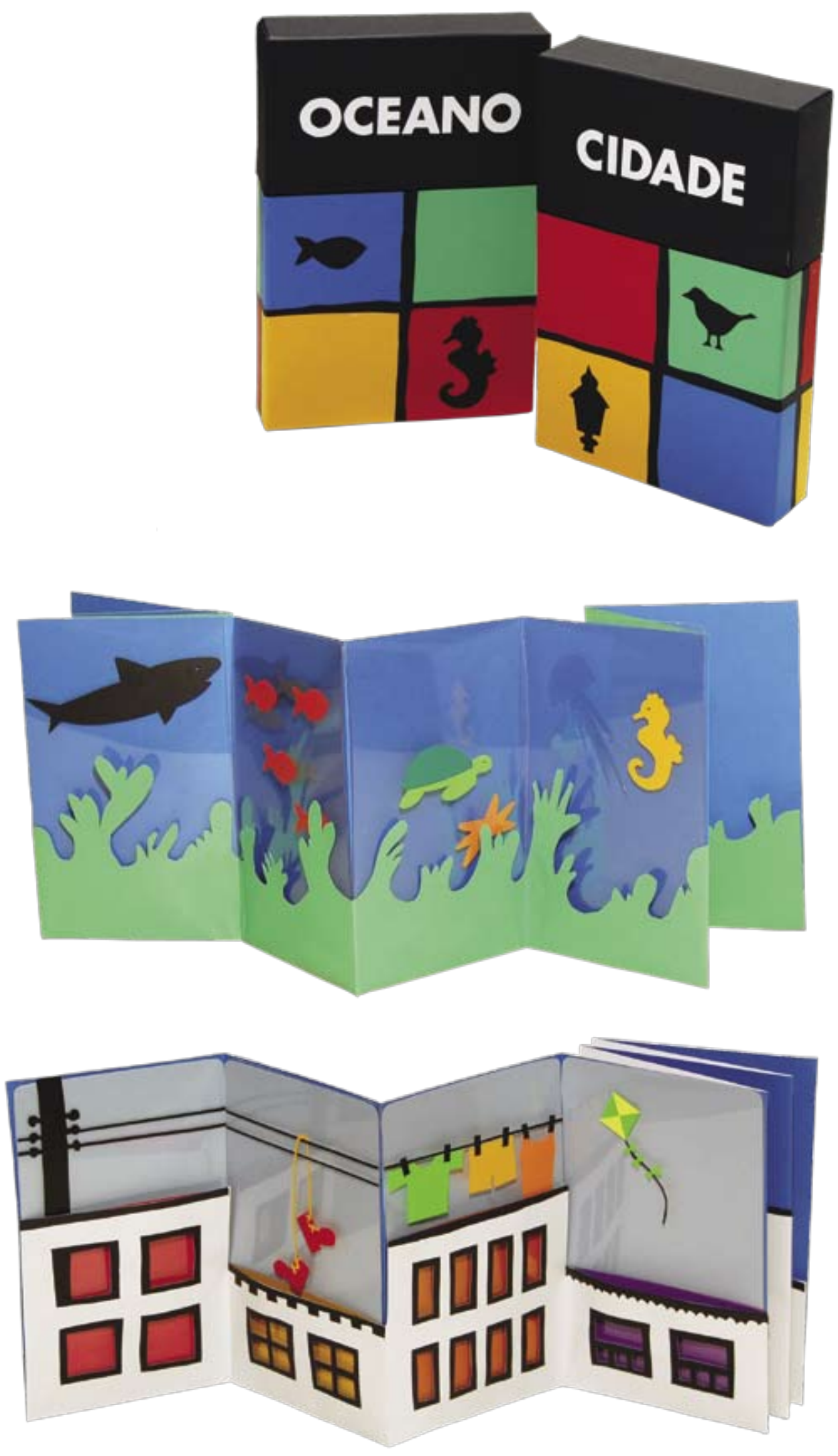


\section{EXPERIMENTO 2}
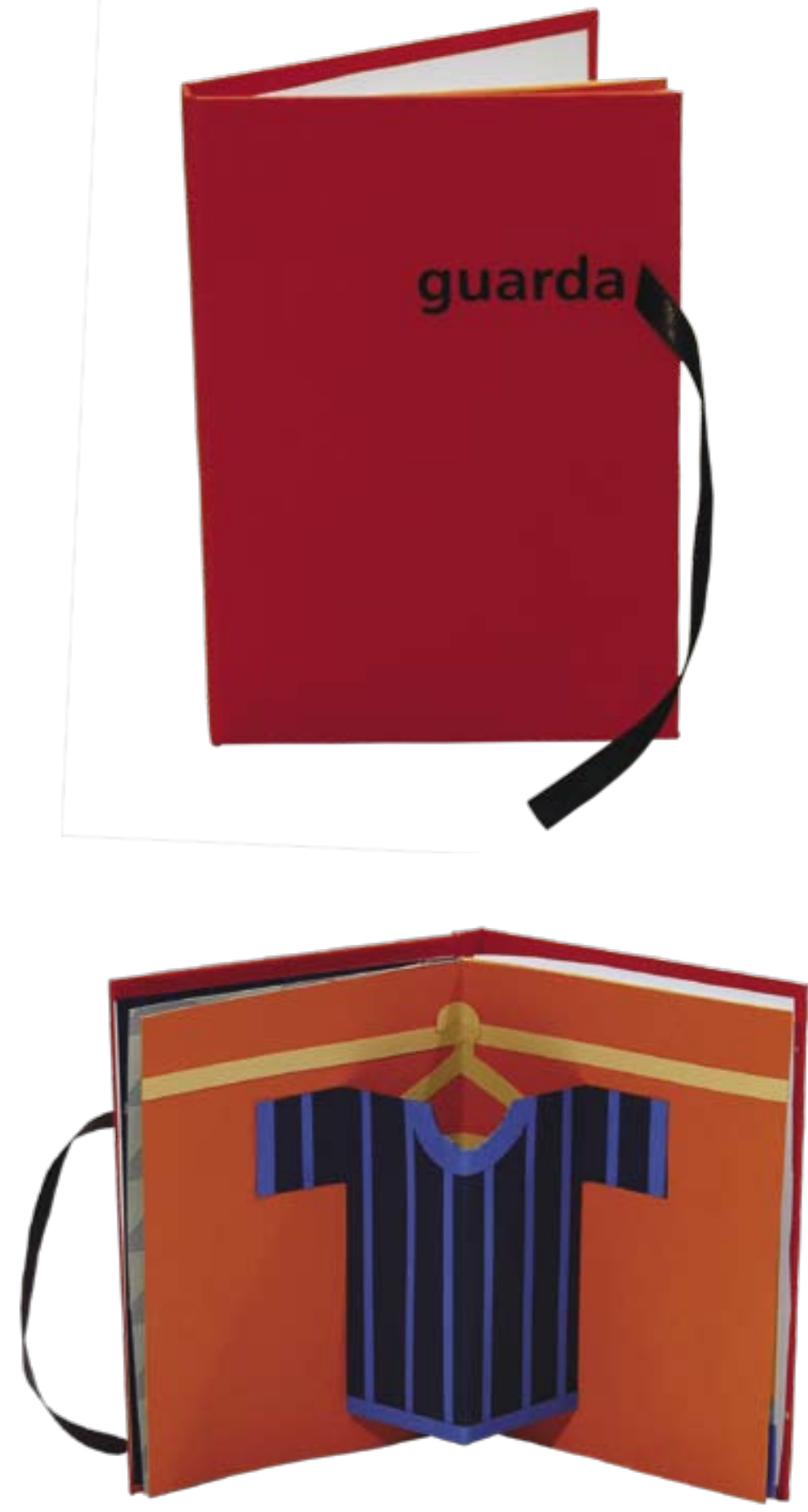

Neste experimento, propõe-se testar as possibilidades da tridimensionalidade através da energia do girar da página, explorando os mecanismos do pop-up. O trabalho apresenta soluções com poucos pontos de cola, optando, sempre que possível, pelas dobras e facas especiais. 


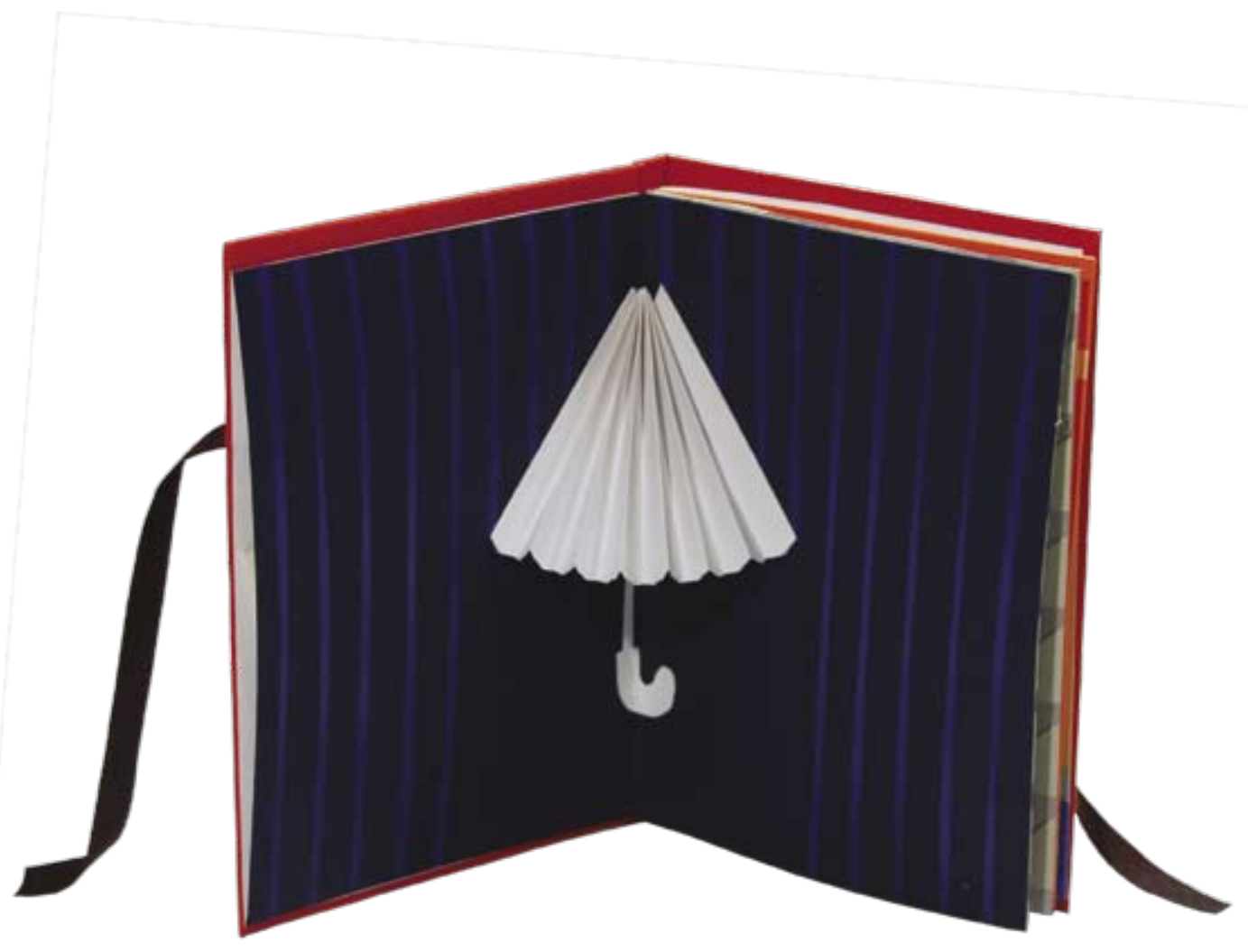

Os exercícios de projeto, neste caso, trabalham com a decomposição das palavras iniciadas por guarda-. Então, busca-se no transcorrer das páginas apresentar cada sentido da palavra guarda- em uma página-dupla. A proposta não é esgotar todos os sentidos estabelecidos com a palavra guarda-, mas mostrar caminhos de projeto.

Há duas propostas de lúdico neste livro-objeto, a surpresa ao virar a página gerada pela expectativa da tridimensionalidade e o jogo de adivinhações. A cada dupla, um conjunto de elementos fornece detalhes de qual guarda- está sendo apresentada, sem, contudo, fornecer a resposta pronta, cabe ao leitor achar a resposta.

Nesta proposta, procurou-se manter o mínimo de elementos para a charada, de forma a fornecer uma leitura fácil. A narrativa visual se dá pela ilustração e tridimensionalidade, sem qualquer presença de texto no miolo.

O ritmo da leitura é estabelecido pelo girar das páginas, comandado pela tridimensionalidade. Mantém-se o mesmo ritmo em todas as páginas deste experimento. Desta forma constrói-se uma unidade no conjunto, não apenas pelo tema ou pela ilustração, mas também pela forma de manipulação.

Os elementos dispostos na posição central da página permitem que o mecanismo interativo, neste caso, a tridimensionalidade, funcione com a ação do movimentar das páginas. A organização das páginas está vinculada aos dispositivos lúdicos, mas sem desprezar o aspecto gráfico do desenho. 

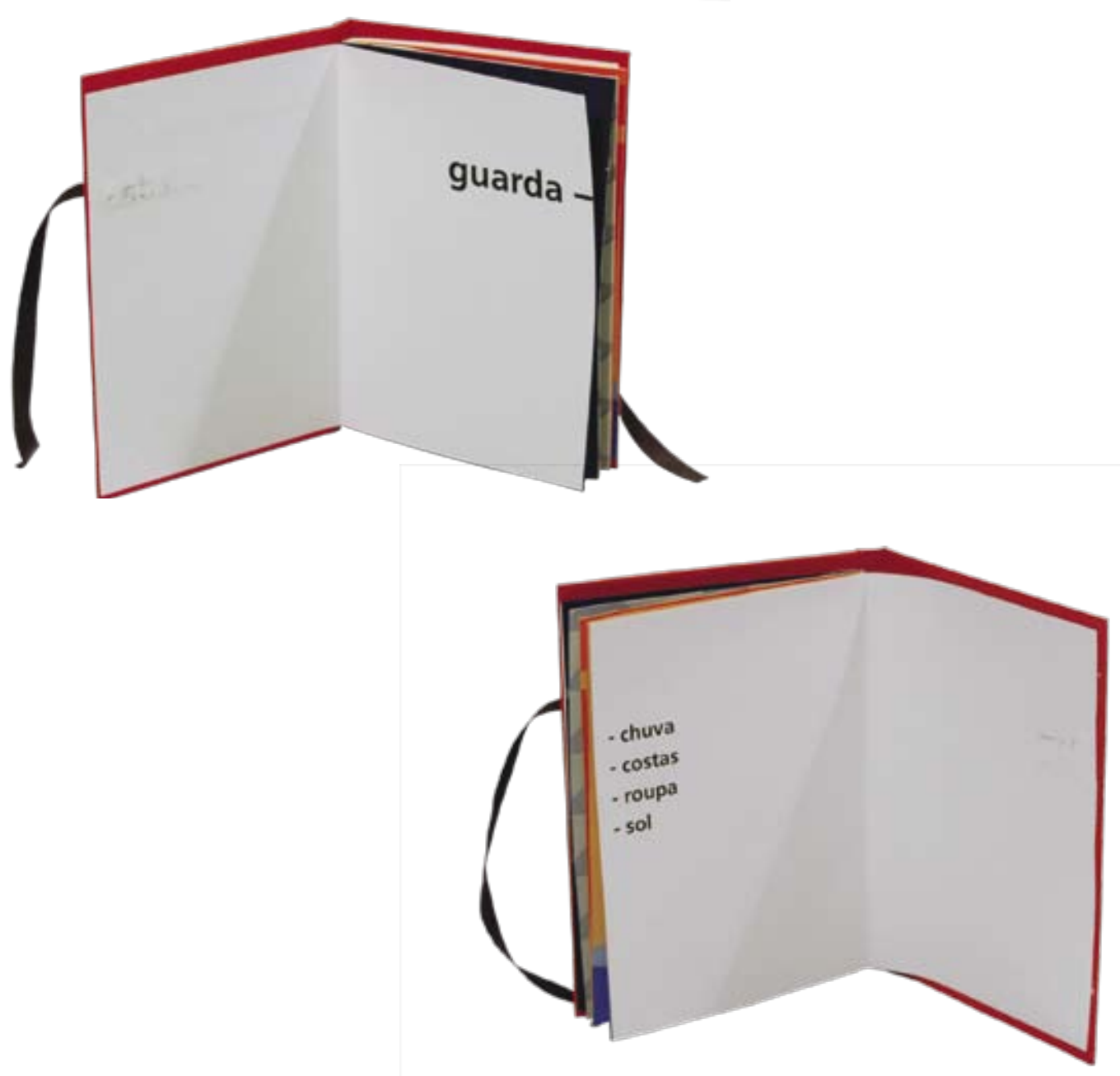

Nas ilustrações, trabalha-se com elementos gráficos baseados em formas simples, geométricas e com poucos detalhes. O objetivo do desenho é estabelecer uma relação com os instrumentos lúdicos desenvolvidos em cada página e ainda manter a unidade do conjunto. As imagens são construídas com recortes de papéis coloridos e adesivos, o que permitiria ser substituído pela impressão serigráfica ou offset.

Este livro-objeto obedece a proporção retangular de $105 \times 148 \mathrm{~mm}$, aberto e $210 \times$ $148 \mathrm{~mm}$, fechado, o que estabelece um aproveitamento de papel se impresso na folha $960 \mathrm{x}$ $660 \mathrm{~mm}$. Na busca por soluções mais delicadas nas páginas, visualmente mais suaves, o tamanho reduzido procura estabelecer a relação de leveza.

A capa dura é trabalhada com a palavra guarda-, escrita em Frutiger bold. A capa é o elemento chave para o entendimento do jogo proposto, por isso é composta apenas de texto. A última página fornece a resposta ao guarda- proposto.

$\mathrm{Na}$ execução deste experimento, as páginas foram coladas uma sobre a outra. Se produzido industrialmente, os cadernos poderiam ser costurados a cada duas folhas. Após a costura e encadernação, as estruturas lúdicas que compõem o pop-up foram coladas nas páginas uma a uma, caso contrário, a costura não seria viável. 

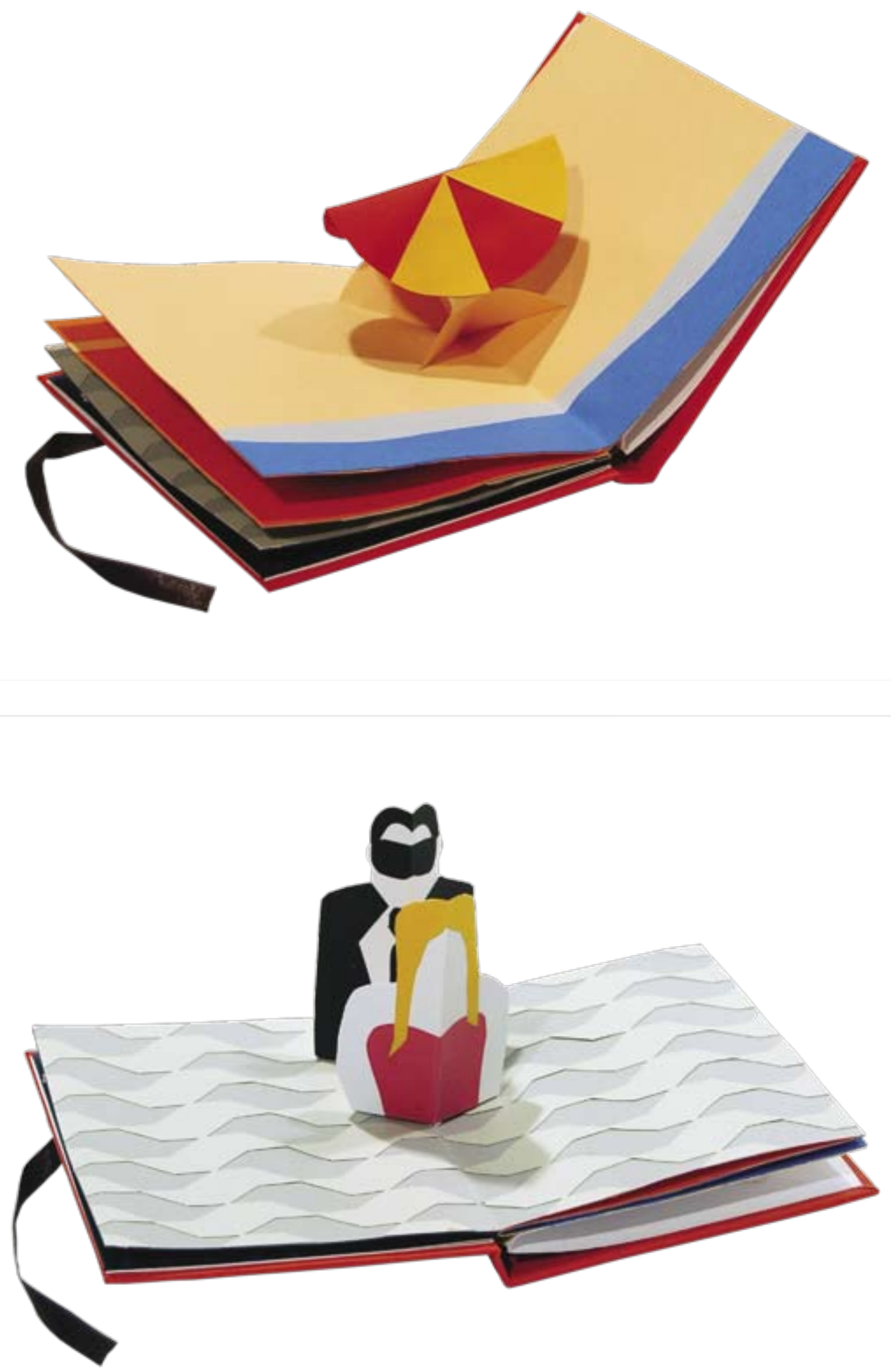


\section{EXPERIMENTO 3}
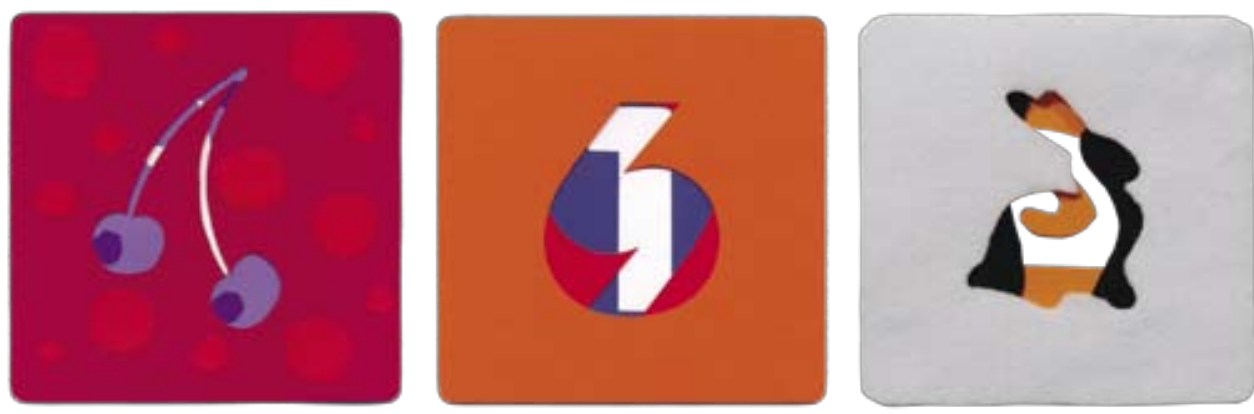

A proposta deste experimento está relacionada ao cheio e ao vazio das ilustrações, trabalha a imagem por meio do vazado. A ausência de material brinca com as imagens sobrepostas e com a possibilidade da adição de cores. A sobreposição das lâminas gera diferentes percepções visuais.

O jogo explorado permite aplicações em diferentes temas. Aqui foram testados na forma de números, frutas e animais, agrupados em família, como uma série. Os temas propostos são recorrentes no universo do livro infantil, apesar da sua simplicidade, fornecem imagens com volumes diferenciados, importantes para o jogo cromático.

O formato adotado neste experimento é de $140 \times 140 \mathrm{~mm}$, o que possibilita um bom aproveitamento do papel, na folha 960 ×660mm obtém-se 24 peças. A proporção quadrada permite manipular as lâminas em diferentes posições, fornecendo maior autonomia às cartelas.

As ilustrações são posicionadas no centro de cada cartela. Desenhos sem muitos detalhes, de forma que não fragilizem os recortes vazados. Utiliza-se cores individuais em cada lâmina, sendo a escolha desta relacionada à disponibilidade do papel.

O experimento utiliza-se do papel colorplus de cores variadas, gramatura de $180 \mathrm{~g}$, recortado manualmente no estilete, o que numa escala industrial justificaria o uso da faca especial para cada lâmina. O material utilizado não possui rigidez suficiente a manipulação, o ideal para o projeto seria trabalhar com gramaturas superiores ao cartão e receber ainda a laminação fosca. Os cantos das peças são arredondados, prevendo que no uso de um material rígido, não se danifique com facilidade durante a manipulação.

Nesta investigação optou-se pela não encadernação, deixando as lâminas soltas, o que permite uma livre manipulação. Testou-se o agrupamento por meio de parafuso, mas a narrativa acaba perdendo parte dos efeitos visuais, bem como a exploração de sequências narrativas.

No experimento com os números, utiliza-se a tipografia Futura bold, altura de corpo 280 pontos. Testaram-se diferentes alturas de números, concluindo que uma altura de corpo maior permite uma brincadeira visual mais rica, proporcionando uma melhor relação de espaço preenchido. No experimento com as frutas, uma outra relação é estabelecida: cada cartela traz uma representação de textura, adicionando novas possibilidades de percepção visual. No experimento com os animais, utiliza-se de materiais com texturas que lembram os personagens representados. 

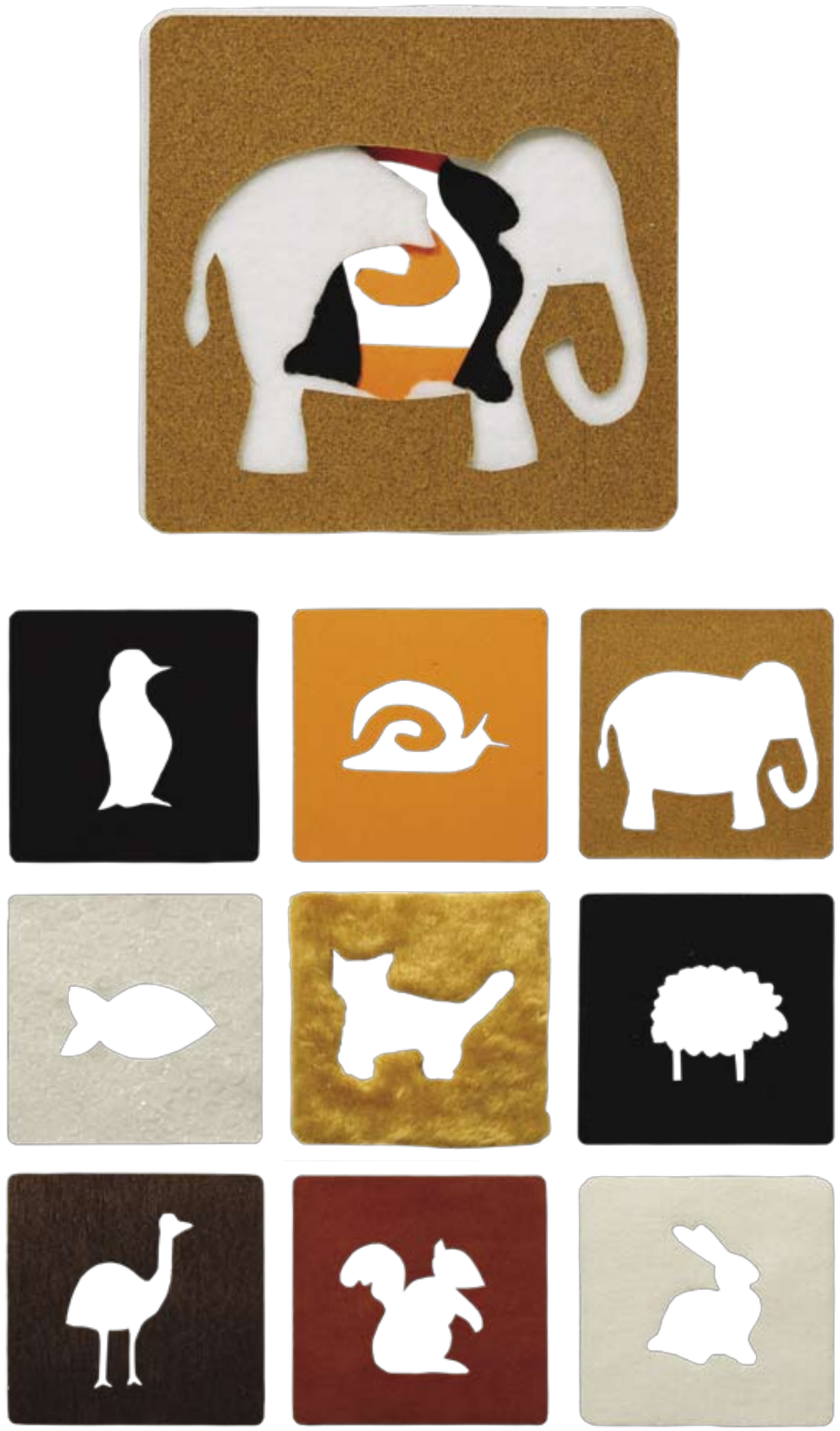

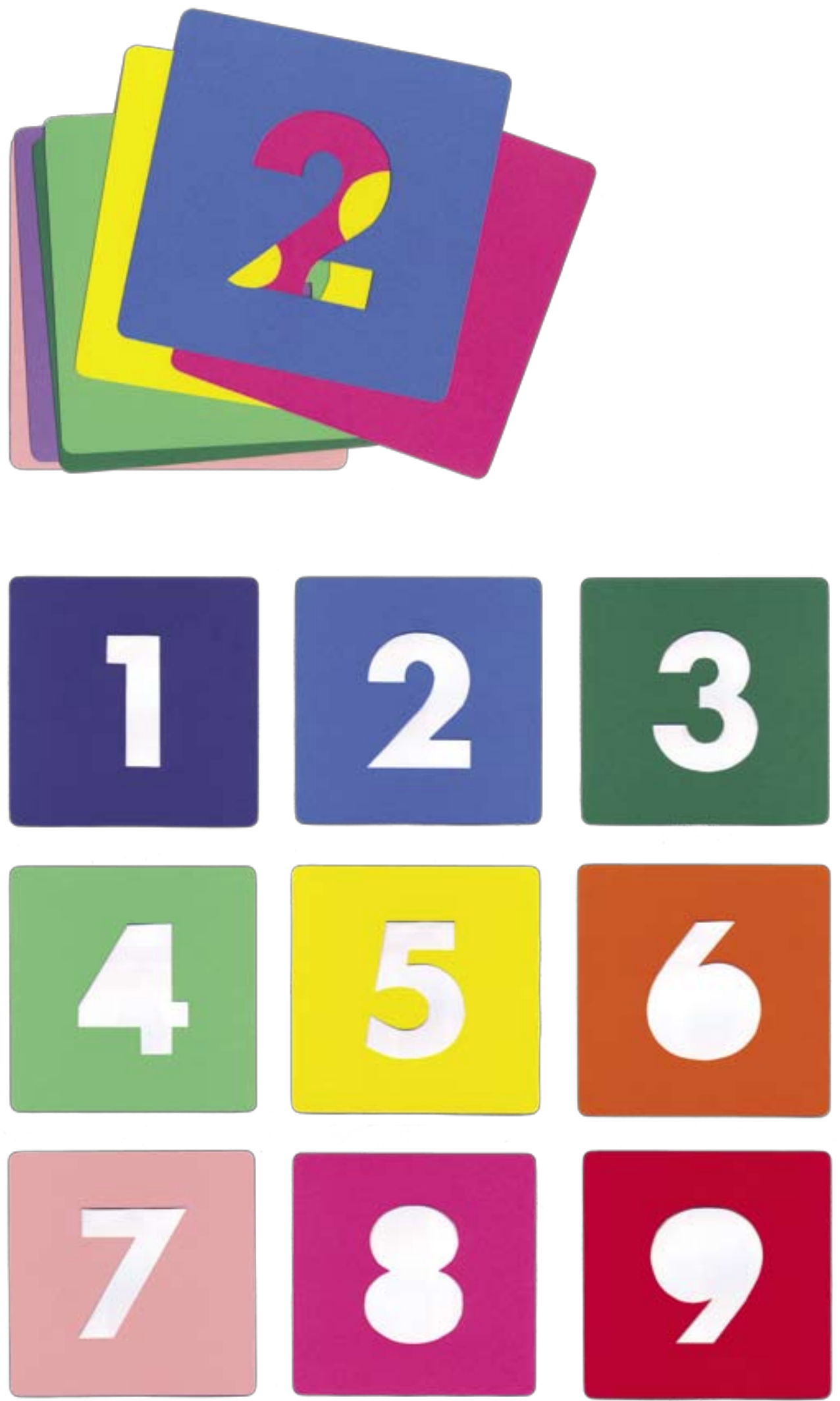

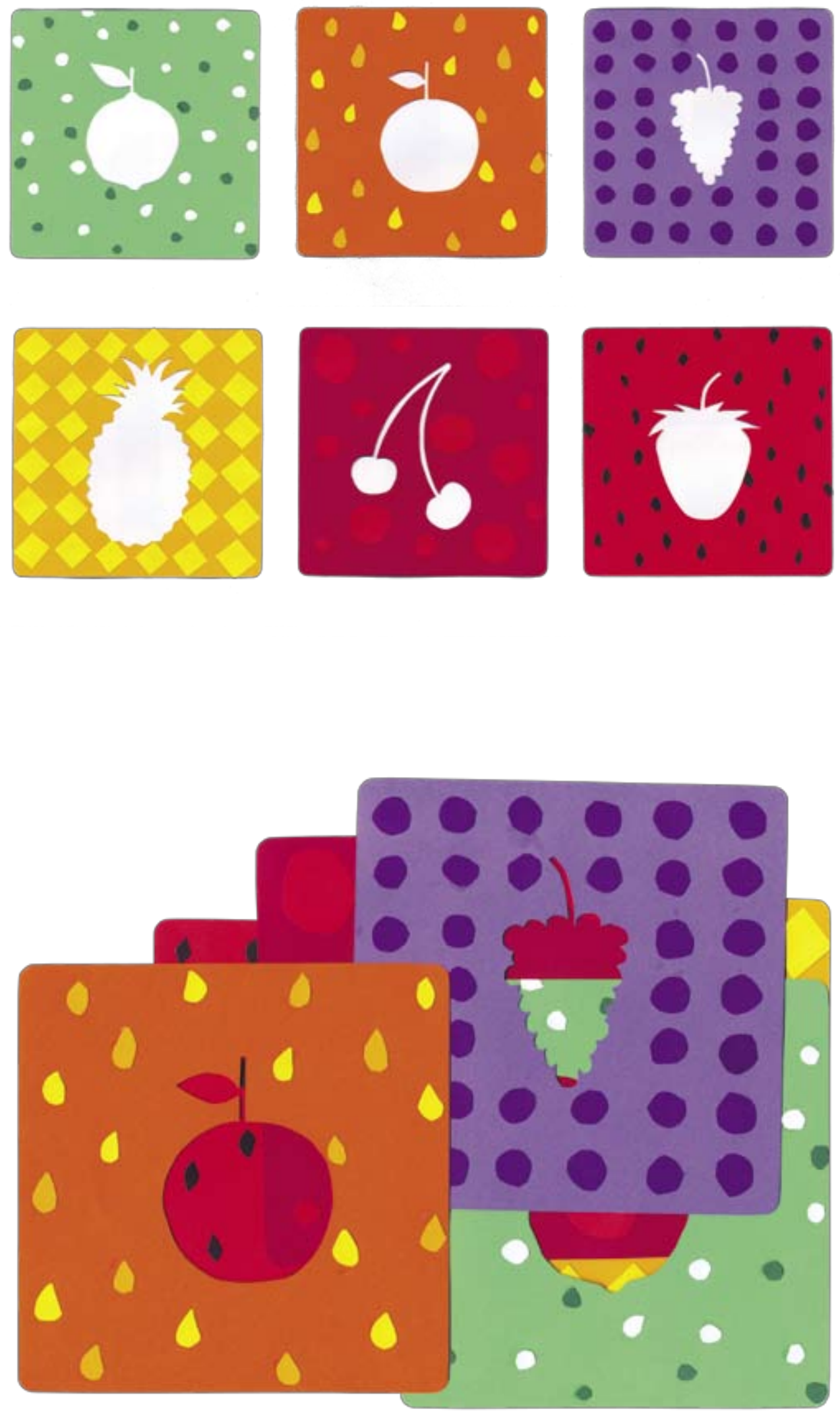


\section{EXPERIMENTO 4}

A proposta deste experimento é articular o objeto com a poesia. $O$ poema escolhido para este experimento é de Augusto de Campos, extraído do livro Viva vaia: poemas 1949. 1979. Um experimento no qual há ausência da ilustração, um trabalho apenas com palavras, semelhante ao lúdico proposto pelos neoconcretos, como Ferreira Gullar.
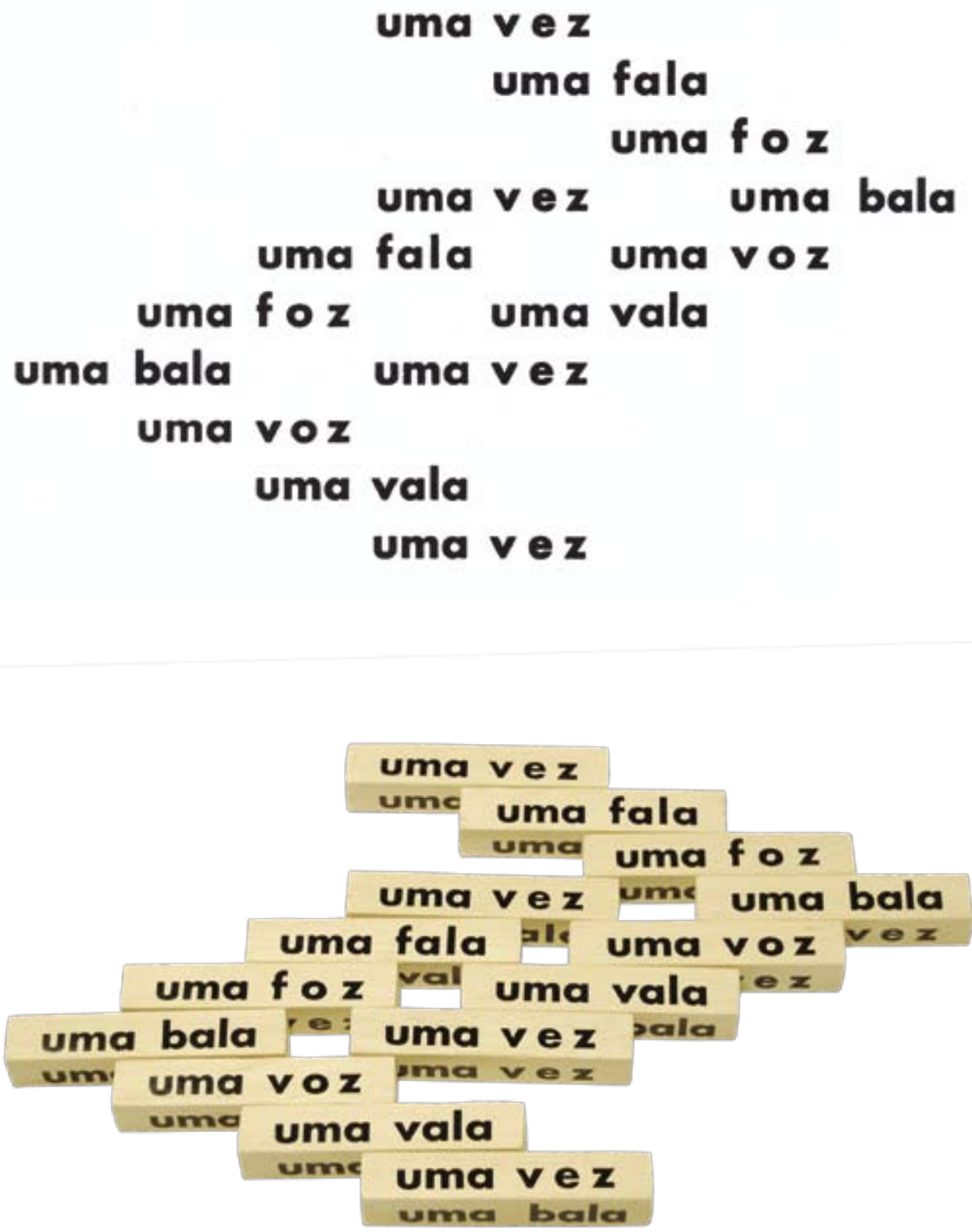


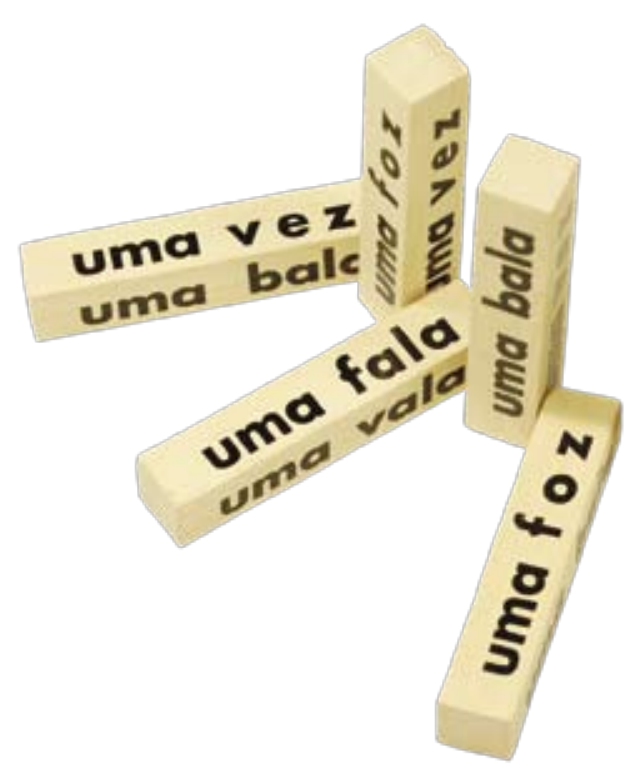

O objeto projetado propõe a manipulação de peças, em que cada peça contém um trecho do poema. Esta separação em partes permite ao leitor permutar parte do poema, recriando a poesia. Na embalagem, o poema é escrito na sequência correta para a leitura, assim o leitor poderá saber como montar o poema original.

O jogo proposto deixa a encargo da manipulação as novas leituras. Estas podem ser aplicadas também na disposição visual, uma vez que as peças não possuem uma base rígida. Ao leitor, dá-se inúmeras possibilidades de montar a poesia.

As peças, neste experimento, são feitas de madeira nas dimensões, $80 \times 15 \times 15 \mathrm{~mm}$, sendo todas do mesmo tamanho. A padronização das peças mantém a unidade do conjunto.

Para a grafia do poema, optou-se pela fonte da família Futura bold, a fim de manter o projeto gráfico original de Julio Plaza. O tamanho da fonte é estabelecido no corpo 33 pontos, o que permite a leitura e o melhor enquadramento no campo proposto. O texto é alinhado centralizado, no sentido horizontal e vertical.
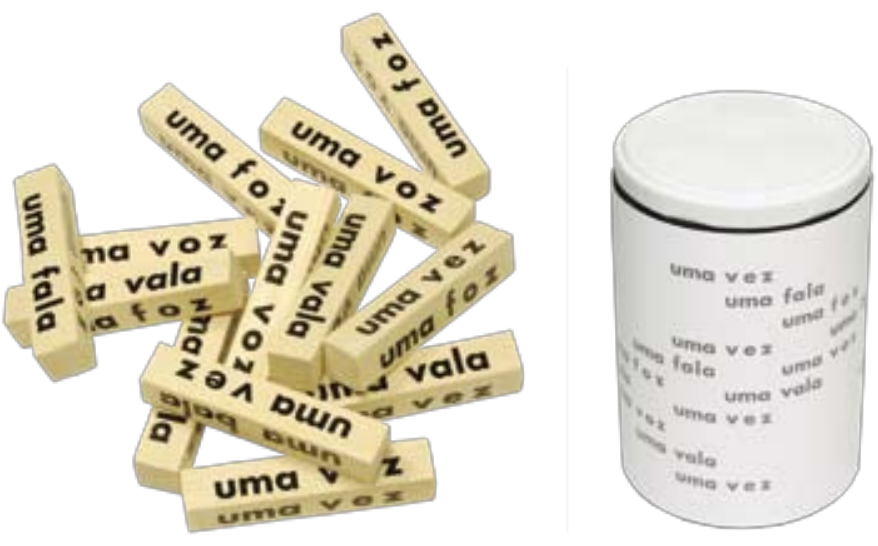


\section{EXPERIMENTO 5}

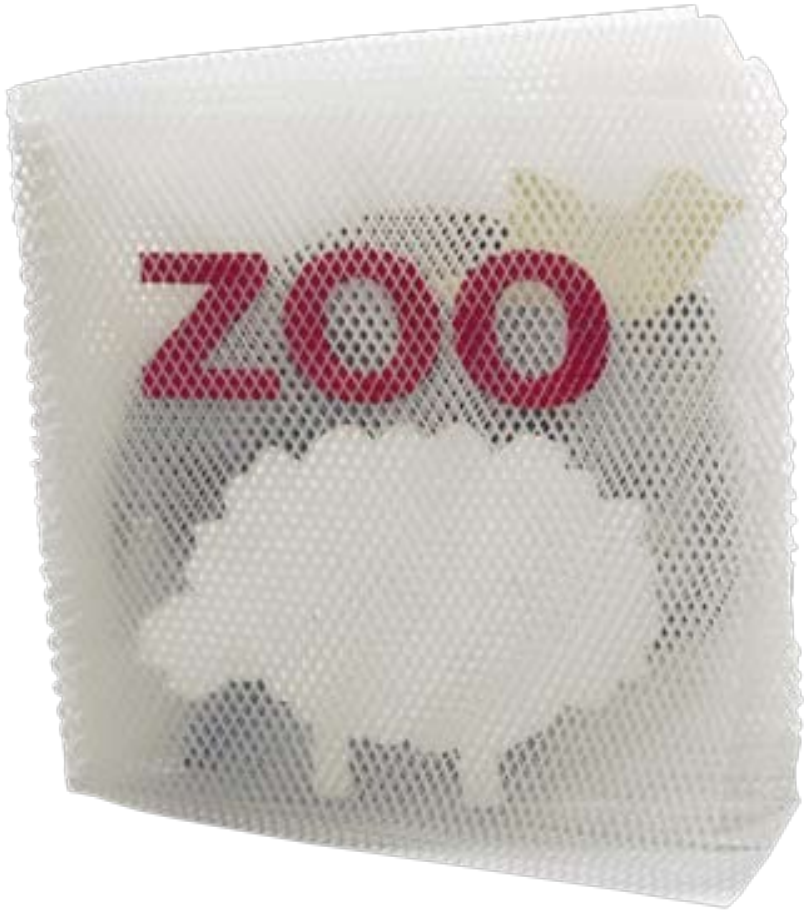

Esta proposta traz os mesmos conceitos do jogo de cheio e vazio do experimento 3 , e, além de manter o vazio das ilustrações, brinca com a textura do material. A proporção é a mesma do experimento anterior, $140 \times 140 \mathrm{~mm}$.

A textura do material relaciona-se com o animal ilustrado: o coelho terá textura suave, o elefante terá textura áspera, e assim por diante. A aplicação da cor busca também esta associação. As texturas foram geradas por diversos materiais, desde industrializados até matérias-primas associadas. Utilizou-se algodão, lixa de madeira, papel de seda, celofane, algodão, e.v.a., papel crepon e feltro.

Esta investigação propõe o jogo sinestésico, além do visual. O leitor é convidado a sentir as diferenças de relevo nas lâminas e compreender as associações estipuladas entre a textura visual e tátil.

Os animais foram colados em lâminas de tela plástica branca, encadernadas com costura lateral. A translucidez das páginas permite vizualizar os animas de forma semelhante as grades de um zoológico, ao mesmo tempo que possibilita o jogo de sobreposições. 

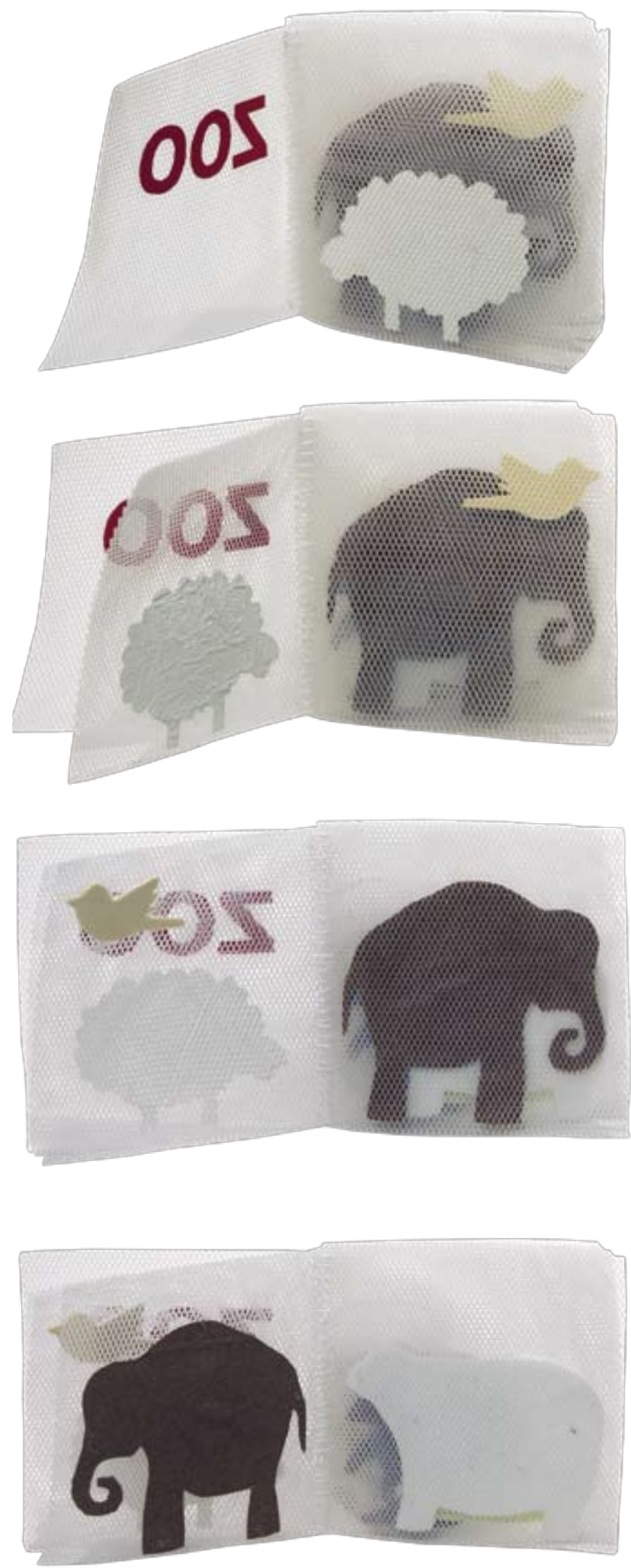
Ex

Ix:

3 
O livro-objeto infantil contemporâneo é um produto do advento do computador na década de 1990, em que são exploradas formas gráficas diferenciadas. Antes deste período, o livro-objeto foi trabalhado como suporte artístico pelos concretistas. Sua expansão restrita deve-se à reprodutibilidade limitada. Atualmente, as inovações tecnológicas, principalmente na indústria gráfica, permitem viabilizar sofisticados projetos visuais. O livro-objeto voltado aos pequenos leitores é um exemplo destas experimentações gráficas associadas aos mecanismos lúdicos.

O lúdico no livro pode ser explorado como suporte à imaginação graças ao seu poder de encantamento sobre o leitor, o que possibilita ampliar as experiências e as perspectivas do imaginário. Para o público infantil, o livro-objeto torna-se envolvente, o que favorece o processo de releitura. O leitor é convidado a explorar os diversos espaços de leitura por meio da manipulação, tornando-se parte ativa da narração. Esta desperta o lado inventivo do leitor, sendo o design responsável pelo encantamento, que semea o hábito de leitura.

Os instrumentos lúdicos definidos por Perrot (1987), classificados em jogo sinestésico, jogo de humor, jogo de adivinhação, jogo de imagens e jogo com recortes, são a base teórica para compreender os mecanismos de manipulação no livro-objeto. A proposta lúdica pode ser trabalhada em conjunto com outros instrumentos, potencializando a fantasia, ou isoladamente.

O jogo no livro-objeto é importante para incentivar o leitor ao contato físico com o objeto. Para esta categoria de livro, o leitor precisa ser um agente ativo, sua participação na manipulação é imprescindível. A forma pela qual esta se estabelece é variada, podendo ser encontrada no formato de aba, recorte localizado, elemento vazado, pop-up, textura, flip, entre outros.

No livro-objeto, o formato e os processos de produção gráfica são os elementos de design que mais influenciam na estrutura lúdica. Apesar da tipografia, da composição imagem-texto e da linguagem visual fazerem parte do design do livro como um todo, estes, por si só, não constroem os instrumentos lúdicos. A sua aplicação correta fortalece o jogo proposto, bem como o torna um objeto visualmente agradável. 
Os estudos de caso, livros de Munari e Pacovská, mostram como parte da teoria sobre design de livros é aplicada e como alguns elementos não são considerados no processo de projeto. Quando se observa o formato, percebe-se a preferência pela proporção quadrada ou retangular retrato, mas as proporções não obedecem a nenhuma relação conhecida, indicando um processo aparentemente intuitivo ou voltado ao melhor aproveitamento do suporte.

Na tipografia, nota-se a preferência pelo uso das famílias clássicas, Futura, Trajan, Univers, Helvetica e Frutiger, que predominam na versão bold. Pacovská utiliza uma altura de corpo considerada grande se comparada a outros livros infantis, desta forma a massa de texto produz impacto, ocupando um espaço maior na página diagramada. Ao contrário, Munari opta pelas caixas de texto compactas, com altura de corpo de 9 pontos. Em ambos os autores, o entendimento do texto está relacionado à imagem, como no picture book.

A organização dos elementos gráficos na página, nos estudos de caso, é estabelecida pela hierarquia visual. Os espaços destinados às imagens e ao texto não obedecem a uma malha estrutural rígida, em muitos livros a malha é inexistente. A distribuição dos elementos no layout prova ser subjetiva na busca do equilíbrio visual.

A linguagem das ilustrações indica as especificidades de cada artista, os desenhos marcam as características do ilustrador, permitindo reconhecer com facilidade a autoria. No caso de Pacovská, predominam as formas geometricas do quadrado, da circunferência e do triângulo, associada ao uso de cores fortes, como vermelho, verde, amarelo e azul. A autora, em diversos livros, trabalha com uma grande massa de vermelho no fundo e nas ilustrações, esta pode ser considerada uma assinatura de suas obras.

As ilustrações de Munari são variáveis em cada livro, trabalhando com técnicas diversas em cada trabalho. Nos livros analisados aqui, predomina uma linguagem direta e enxuta, sem muitos ornamentos. Em muitos livros, Munari ilustra com cores chapadas e numa única cor, o que resulta numa leitura rápida. Defende, dessa forma, uma linguagem com o caráter universal para que todos os leitores compreendam a mensagem.

A produção gráfica mostra-se importante nas obras analisadas, que exploram recursos diferentes na obtenção do lúdico. Pacovská trabalha com a impressão em cinco cores e hot stamping, associando as facas especiais e os recortes para produzir janelas e pop-up. Munari centra sua exploração no uso do suporte diferenciado e nas facas especiais, trabalhando com as sobreposições. Em ambos os autores, a faca mostra-se um recurso essencial para o jogo proposto, mesmo tendo usos diversos em cada caso.

A investigação do livro-objeto por meio de experimentos gráficos permite avaliar os caminhos do projeto. Os experimentos, agrupados pela função lúdica, mostram como as ferramentas do design estimulam a manipulação do livro. Os mecanismos lúdicos, dobra sanfonada, recorte especial, suporte diferenciado e estruturas tridimensionais, são explorados em meio a temas recorrentes no meio editorial infantil.

Estes experimentos são construídos de forma artesanal, mas passíveis de serem produzidos. Folhas coloridas, adesivos e materiais diversos ilustram os livros-objeto propostos, utilizando-se de uma linguagem visual econômica em detalhes. As ilustrações fornecem a unidade dos trabalhos, e mantêm as mesmas características gráficas do recorte. 
Os estudos mostram que o projeto de livro-objeto segue um caminho mais intuitivo no processo de trabalho, mas alguns pontos podem ser, posteriormente, reavaliados, como o ajuste de proporção, os alinhamentos, a linguagem das ilustrações, a escolha da tipografia, o tamanho da caixa de texto.

O livro-objeto é um campo rico em explorações gráficas, e de novas possibilidades de leitura durante sua manipulação. Apesar da importância do livro-objeto infantil, sua publicação é ainda restrita a poucas editoras, e se encontra reduzida bibliografia teórica sobre o tema. 
AMBROSE, Gavin, HARRIS, Paul. Impressão \& Acabamento. Trad. Edson Furmankiewicz. Porto Alegre: Bookman, 2009.

ARAÚJO, Emanuel. A construção do livro: princípios da técnica de editoração. 2 ed. revisada e atualizada. Rio de Janeiro: Lexikon Editora Digital; São Paulo: Fundação Editora da UNESP, 2008.

AZEVEDO, Ricardo. "Aspectos instigantes da literatura infantil e juvenil". IN: OLIVEI$\mathrm{RA}$, leda de (Org.). O que é qualidade em literatura infantil e juvenil?: com a palavra, o escritor. São Paulo: DCL, 2005.

BAER, Lorenzo. Produção gráfica. 6 ed. São Paulo: Editora SENAC, 2009 [1999].

BENJAMIN, Walter. Reflexões sobre a criança, o brinquedo e a educação. Tradução, apresentação e notas de Marcus V. Mazzari; posfácio de Flávio Di Giorgi. São Paulo: Duas Cidades; Editora 34, 2002.

BROCKMANN, Josef Müller. Sistemas de grelhas: um manual para desenhistas gráficos. Barcelona: Gustavo Gili, 1982.
BROÜGÈRE, Gilles. Jogo e educação. Trad. Patrícia Chittoni Ramos. Porto Alegre: Artes Médicas, 1998.

\section{Brinquedos e Companhia}

Tradução Maria Alice Sampaio Doria. São Paulo: Cortez, 2004.

CAILLOIS, Roger. Los juegos y los hombres. Trad. Jorge Ferreiro. 4 ed. México: Fondo de cultura económica, 1994.

CAMPOS, Augusto de. Viva vaia: poesia 1949-1979. 4 ed. São Paulo: Ateliê Ed, 2007.

COELHO, Nelly Novaes. Literatura infantil: teoria, análise, didática. São Paulo: Editora Moderna, 2000.

COLLARO, Antonio Celso. Produção Gráfica: arte e técnica da mídia impressa. São Paulo: Pearson Pretice Hall, 2007

DEHÒ, Valério (Org.). Children's corner: artist's books for children: catálogo Mantova: Corraini, 2007. 
DONDIS, Donis A. Sintaxe da linguagem visual. 3 ed. Trad. Jefferson Luiz Camargo. São Paulo: Martins Fontes, 2007 [1991].

\section{ELAM, Kimberly. Geometria do design} Trad. Claudio Marcondes. São Paulo: Cosac Naify, 2010.

FERLAUTO, Cláudio; JAHN, Heloisa. o livro da gráfica. 3 ed. São Paulo: Edições Rosari, 2001.

FURNARI, Eva. Propostas de desenvolvimento de uma linguagem puramente visual. In: Olhar de descoberta: proposta analitica de livros que concentram várias linguagens. São Paulo: Paulinas, 2003. p.65-67.

GÓES, Lucia Pimentel. Olhar de descoberta: proposta analitica de livros que concentram várias linguagens. 2. ed. São Paulo: Paulinas, 2005.

GULLAR, Ferreira. Experiência neoconcreta. São Paulo: Cosac Naify, 2007.
HALLEWELL, Laurence. O livro no Brasil Trad. Maria da Penha Villalobos, Lólio Lourenço de Oliveira e Geraldo Gerson de Souza. 2 ed. revisada e ampliada. São Paulo: Edusp, 2005. p. 695-752.

HASLAM, Andrew. O livro e o designer II: como criar e produzir livro. Trad. Juliana A. Saad e Sergio Rossi Filho. São Paulo: Edições Rosari, 2007 [2006].

HELLER, Steven, GUARNACCIA, Steven. Designing for children. New York: Watson-Guptill Publications, 1994.

HELLER, Steven. Linguagens do design: Juliana Saad. São Paulo: Edições Rosari, 2007 [2004].

HENDEL, Richard. O design do livro. Trad. Geraldo Gerson de Souza e Lúcio Manfredi. São Paulo: Ateliê Editorial, 2003 [1999].

HUIZINGA, Johan. Homo ludens: o jogo como elemento da cultura. Trad. João Paulo Monteiro. 5 ed. São Paulo: Perspectiva, 2007. Coleção Estudos. 
HURLBURT, Allen. Layout: o design da página impressa. 2 ed. Trad. Edmilson $O$. Conceição; Flávio M. Martins. São Paulo: Nobel, 1986 [1977].

LIMA, Graça. "Lendo imagens". In: Nos caminhos da literatura. São Paulo: Peirópolis, 2008. Coleção primeiros passos. p.35-45.

LINDEN, Sophie Van der. Lire l'album. França: L'atelier Du Poisson soluble, 2007.

LINS, Guto. Livro infantil?: Projeto gráfico, metodologia, subjetividade. São Paulo: Edições Rosari, 2003.

LUPTON, Ellen; PHILLIPS, Jennifer C. Novos fundamentos do design. Trad. Cristian Borges. São Paulo: Cosac Naify, 2008.

MAFFEI, Giorgio, PICCIAU, Maura. II libro come opera d'arte. Itália: Corraini, 2008.

MUNARI, Bruno. Artista e designer. Portugal: Edições 70, 2001 [1971].
Das coisas nascem coisas.

Trad. José Manuel de Vasconcelos. São Paulo: Martins Fontes, 1998 [1981].

Design e comunicação visual: contribuição para uma metodologia didática. Trad. Daniel Santana. São Paulo: Martins Fontes, 1997.

Fantasia. Trad. José Jacinto Correia Serra. Portugal: Edições 70, 2007.

NIKOLAJEVA, Maria; SCOTT, Carole. How picturebooks work. United States of America: Routledge, 2006 [2001].

NODELMAN, Perry. Words about pictures: the narrative art of children's picture books. United States of America: University of Georgia Press, 1988.

OLIVEIRA, Rui de. Pelos Jardins Boboli: Reflexões sobre a arte de ilustrar livros para crianças e jovens. Rio de Janeiro: Nova Fronteira, 2008.

PACOVSKÁ, Květa. À I'infini. Paris: Éditions du Panamá, 2007. 
tiles. Barcelona: Gustavo Gili, 2007.

PAIVA, Ana Paula Mathias de. A aventura do livro experimental. Belo Horizonte: Autêntica Editora; São Paulo: Edusp, 2010.

PERROT, Jean. Du jeu, des enfants et des livres. Paris: Du cercle de La librairie, 1987. Collection Bibliotheques.

PERROTTI, Edmir. Confinamento cultural, infância e leitura. São Paulo: Summus, 1990. (col. Novas buscas em educação; v.38)

POWERS, Alan. Era uma vez uma capa. Trad. Otacílio Nunes. São Paulo: Cosac Naify, 2008.

ROCHA, Claudio. Projeto tipográfico: análise e produção de fontes digitais. São Paulo: Edições Rosari, 2002.

SAMARA, Timothy. Grid: construção e descontrução. Trad. Denise Bottmann. São Paulo: Cosac Naify, 2007 [2002].

SALISBURY, Martin. Imágenes que cuentan: nueva ilustración de libros infan-
SILVEIRA, Paulo Antonio. A página violada: da ternura à injúria na construção do livro de artista. Porto Alegre: Editora da Universidade UFRGS, 2001.

SHULEVITZ, Uri. Writing with pictures: how to write and illustrate children's books. United States of America: Paperback edition, 1997 [1985].

TSCHICHOLD, Jan. A forma do livro: ensaios sobre tipografia e estética do livro Trad. José Laurenio de Melo. São Paulo: Ateliê Editorial, 2007 [1975].

VILLAS-BOAS, André. Produção gráfica para designers. 3 ed. ampliada. Rio de Janeiro: 2AB, 2008.

ZILBERMAN, Regina. Como e por que ler a literatura infantil brasileira. Rio de Janeiro: Objetiva, 2005. 
AHLBERG, Janet e Allan. 0 carteiro chegou. Trad. Eduardo Brandão. São Paulo: Companhia das Letrinhas, 2007 [1986].

BARUZZI, Agnese; NATALINI, Sandro. A Verdadeira História de Chapeuzinho Vermelho. São Paulo: Brinque-book, 2009 [2007].

BAUER, Jutta. A rainha das cores. Trad. Manuel Olívio. São Paulo: Cosac Naify, 2003.

BERGER, Carin; JOHNSON, Tracy Sunrize. All mixed up. San Francisco: Chronicle

DELAFOSSE, Claude; KRAWCZK, Sabine.

Os Monstros. Trad. Regina Garcia. São Paulo: Melhoramentos, 1996 [1993]. Coleção Meus papéis mágicos.

DELAFOSSE, Claude; PRUNIER, Jame's. Dinosaurio. Espanha: editorial Oceáno, 2008. Coleção Primeros descubrimientos.

FURNARI, Eva. Angelito. São Paulo: Editora Ática, 1997.

GILL, Bob. Bob Gill's A to Z. Mantova: Edizioni Corraini, 2009 [1962].

GOFFIN, Jossue. Oh! São Paulo: Martins Fontes, 1995 [1991].

CALI, Davide; il. Serge Bloch. Fico à espera... Trad. Marcos Siscar. São Paulo: Cosac Naify, 2007 [2005].

COUSINS, Lucy. O livro de surpresas da Ninoca. São Paulo: Editora Ática, 2006 [2001]. Coleção Ratinha Ninoca.

CRESPI, Giuliana; II. Carlo Michelini. Rodando, rodando... Trad. Stella Carr. São Paulo: Maltese, s.d. [1987].

GUILLOPPÉ, Antoine. Lobo Negro. São Paulo: Melhoramentos, 2004.

JACQUES, Benoit. Flip book Le Petit Chaperon Rouge. France: Benoit Jacques Books, 2001.

LAND, Fiona. Cores. São Paulo: Editora Caramelo, 2006. Col. Toque e Descubra. 
LAVATER, Warja. Le Petit Chaperon Rouge. Paris: Adrien Maeght Editeur, 2009 [1965].

LIONNI, Leo. Pequeno Azul e Pequeno

Amarelo. Trad. Newton Cassiolato. São Paulo: Berlendis \& Vertecchia, 2005 [1959].

LIPPMAN, Peter. The Enchanted Castle. New York: Workman Publishing Company, 1995.

MANTEGAZZA, Giovanna; il. Donata Montarini. El museo. Buenos Aires: Atlântida, 2007 [2003].

MARI, Enzo. Il gioco delle favole. Mantova: Edizioni Corraini, 2009 [1965].

MUNARI, Bruno. Le forchette di Munari Mantova: Edizioni Corraini, 2005 [1958].

Livro illeggibile MN1. Mantova: Edizioni Corraini, 2009 [1949].

Na noite escura. São Paulo:

Cosac\&Naify, 2007 [1956].
Più e meno. Mantova: Edizioni

Corraini, 2008 [1970].

The circus in the mist. Mantova: Edizioni Corraini, 2006 [1968].

NEWELL, Peter. O livro do foguete. Trad. Ivo Barroso. São Paulo: Cosac Naify, 2008.

O livro inclinado. Trad. Alípio Correia de Franca Neto. São Paulo: Cosac Naify, 2008 [1910].

PACOVSKÁ, Květa. Alphabet. Alemanha: Ravensburger Buchverlag, 1996. Jamais Deux Sans Trois

França : Éditions Du Seuil, 1996 [1990]. João e Maria: Jacob Grimm Trad. Mônica Rodrigues da Costa, Jamil Maluf. São Paulo: Cosac Naify, 2009 [2008].

MidNightPlay. United States:

North-South Books, 1994 [1992].

O reizinho das flores. São

Paulo: Martins Fontes, 1992 [1991]. 
PIENKOWSKI, Jan. A casa mal-assombrada. Trad. Rosa Amanda Strausz. São Paulo: Editora Moderna, 2006 [1979].

POTTER, Beatrix. Peter Rabbit: a Lucky

Escape. New York: Penguim Group, 2007.

RAND, Ann \& Paul. I know a lot of things. San Francisco: Chronicle books, 2009 [1956].

Little 1. San Francisco: Chronicle books, 2006 [1962].

ROSA, João Guimarães. II. Roger Mello. Zoo. Org. Luiz Raul Machado. Rio de Janeiro: Nova Fronteira, 2008.

SABUDA, Robert. Alice's Adventure in Wonderland: a pop adaptation of Lewis Carrol's original tale. New York: Simon \& Schuster Children's Publishing Div, 2003.

SCHRITTER, Istvan. Detrás de él estava su nariz. Buenos Aires: Del Eclipse, 2008.

SENDAK, Maurice. Donde viven los monstruos. México: Alfaguara, 2006 [1963].
SENDER, Rufus Butler. Galope! Trad. Virginie Leite. Rio de Janeiro: Sextante, 2007.

SILVERSTEIN. Shel. Uma girafa e tanto Trad. Ivo Barroso. São Paulo, Cosac Naify, 2003 [1964].

SHYAM, Bhajju, BAI, Durga, URVETI, Ram. A vida secreta das árvores. Trad. Monica Stahel. São Paulo: Editora WMF Martins Fontes, 2010 [2006].

TRIER, Walter. Gente Maluca. São Paulo: Edições Melhoramentos, sd.

WEISS, Luise. Dentro do espelho. São Paulo: Cosac\&Naify, 2002. 